\title{
AN ANALYSIS OF HOW POLITICAL GOVERNANCE OF \\ LIQUID FUELS CONTRIBUTES TO ENERGY SECURITY IN \\ PAPUA NEW GUINEA
}

\section{BY FRANCIS HUALUPMOMI}

\begin{abstract}
A thesis
submitted to the Victoria University of Wellington in the fulfilment of the requirements for the degree of Doctor of Philosophy in Public Policy
\end{abstract}

Victoria University of Wellington

(July 2019) 



\begin{abstract}
This study examines how political governance of liquid fuels at the institutional level contributes to energy security in Papua New Guinea (PNG) from a political economic perspective. An interpretive methodology and critical case analysis design were used to analyse LNG energy governance regime (policies, legislation, and institutions) and its relationship with energy security. The research design involved analysis of participants' observations and documents in relation to the critical cases (instances) in the practice of the energy regime under the Somare and O’Neill governments between 2002 and 2017.

By using the characteristics of the Quality Energy Governance Framework (QEGF) which emerged from the analysis of the literature on energy governance and energy security, this study shared a new policy insight that energy security is actually created through the interactions that occur between political actors and the institutions and processes of energy governance. The study found that energy governance is a system of interacting institutions, policies and legislation created by the political institutions for the purpose of achieving economic efficiency in order to produce public value. The effective functioning of this system depends on the quality of the political institutions. A strong political institution constructs a quality policy regime which, in turn, translates into operational and adaptive qualities of an energy regime that enhances energy security. Alternatively, where a political institution is weak, the operational and adaptive qualities of the energy governance system are also incrementally diminished, thus generating energy insecurity, which, in turn, affects development outcomes.
\end{abstract}

Accordingly, the study concludes that in PNG the qualities of the energy governance system did not seem to effectively function efficiently as a whole due to the politicaleconomic interests and non-compliance to the institutional qualities. This, in turn, has had the effect of generating energy insecurity rather than enhancing energy security. In effect, the practices associated with the formal governance arrangements have failed to deliver a consistent and predictable governance system for PNG LNG and development outcomes have suffered as a result. The social interaction of political and economic actors and their interests in the energy governance system is complex and quite difficult to predict, resulting in an unstable energy regime. Given the unpredictability of this energy regime, political reform should assume primacy as a first order priority to withstand emerging energy governance issues and challenges that might contribute to energy insecurity. 


\section{Acknowledgments}

This thesis would not have been possible without the contribution of several individuals and organisations. Firstly, I am extremely grateful to the 20 participants whose perspectives contributed to this thesis. I also would like to appreciate the invaluable contribution of my two supervisors, Associate Professor Graham Hassall and Dr Elizabeth Eppel. I'm greatly thankful for your constructive feedback along the way. I would like to extend my sincere appreciation to Professor Cecilia Nembou, President of the Divine Word University and Mr Solomon Wanis Tapura, Master of Law Student at the Victoria University of Wellington for reviewing my thesis from a Papua New Guinean perspective.

I acknowledge the Victoria University of Wellington, the Office of the Assistant Vice Chancellor (Pasifika), in particular Dame Winnie Laban Luamanuvau and the School of Government; the Papua New Guinea High Commission in New Zealand and the PNG Department of Higher Education Research Science \& Technology for the administrative support during my three years of study. My appreciation is also extended to my friends and colleagues for moral support.

Finally, I thank my immediate family members for all the support accorded to me.

This thesis is dedicated to my parents, late Pitawa Hualupmomi and Martina Yavingy Hualupmomi.

I give Glory and Honour to God Almighty for His infinite Wisdom, Understanding and Knowledge! Without Him, I would not have come this far. 


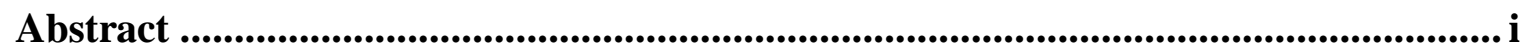

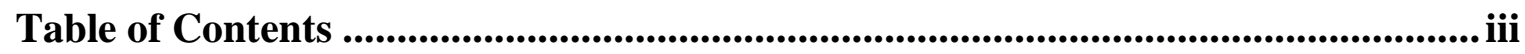

Abbreviations or Acronyms ................................................................................................ vi

List of Figures, Tables, Appendices, Map and Pictures ................................................ ix

CHAPTER 1: CONTEXT OF THE RESEARCH .............................................. 11

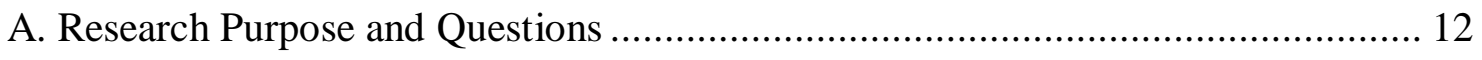

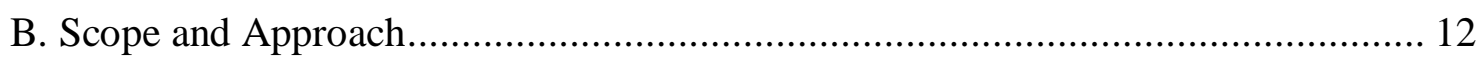

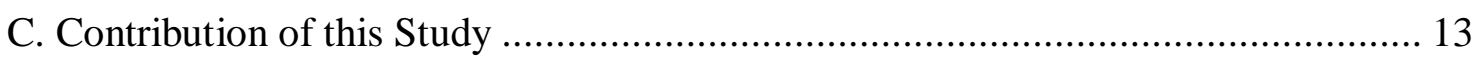

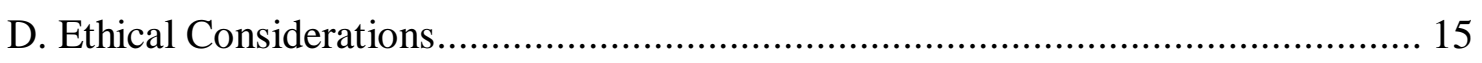

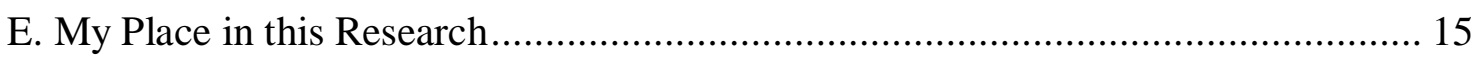

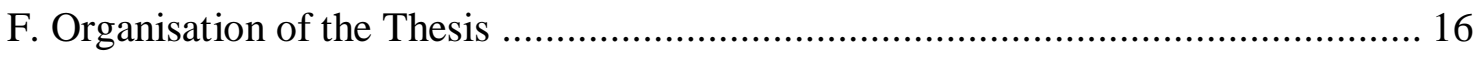

CHAPTER 2: LITERATURE REVIEW ......................................................... 18

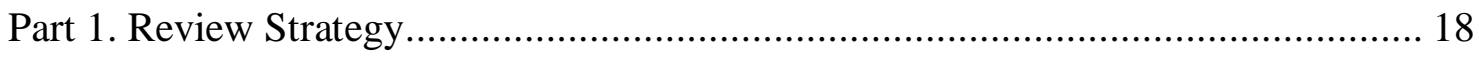

Part 2. Definitions of Energy Security and Energy Governance .............................. 19

Part 3: A Survey of Energy Security Literature ….................................................... 23

Part 4. Energy Security in OECD Countries and Resource-Rich Developing

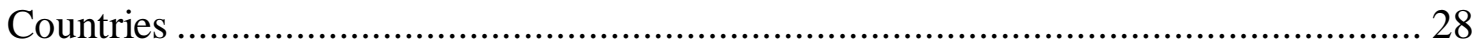

Part 5. Political and Economic Contributions to Governance of Energy Security........ 32

Part 6. Governance and Accountability Reports ............................................. 37

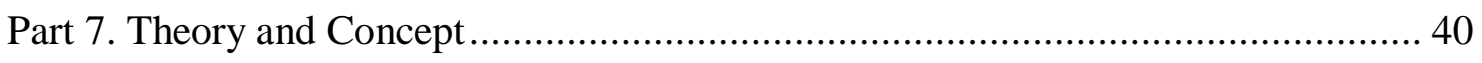

Part 8. Summary - Research gap in this study .............................................. 43

Part 9. A Quality Energy Governance Framework (QEGF) .................................. 44

CHAPTER 3: BACKGROUND...................................................................... 48

Part 1. Political and Economic System of Papua New Guinea ............................... 48

Part 2. Papua New Guinea Petroleum and Energy Context ................................... 57 
Part 3. Institutions and Policy and Legislation

Conclusion

Chapter 4: Research Design and Methodology ..................................................68

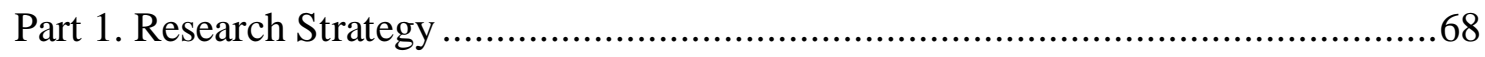

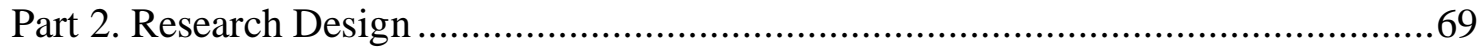

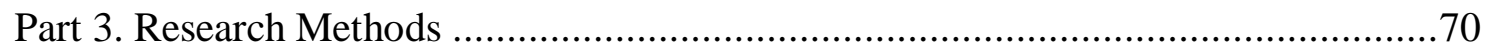

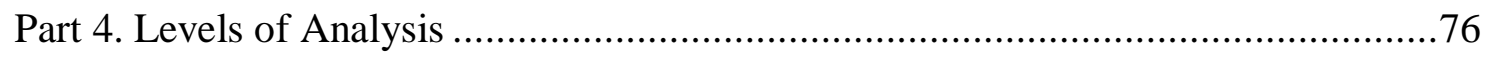

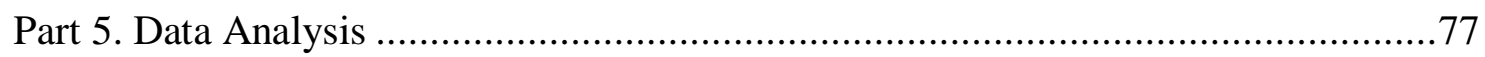

Part 6. Managing Research Challenges .......................................................... 79

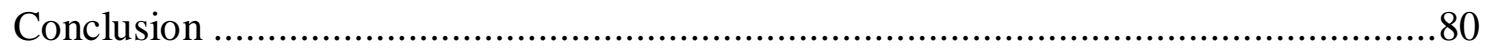

CHAPTER 5: LNG ENERGY GOVERNANCE FRAMEWORK ...........................81

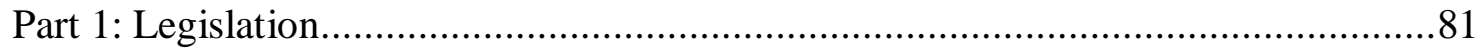

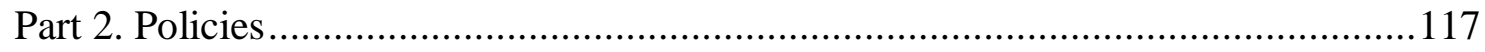

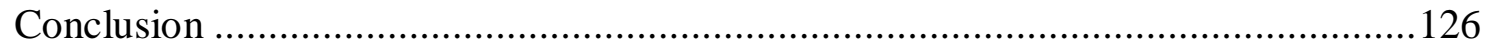

\section{CHAPTER 6: IMPLEMENTATION OF LNG ENERGY GOVERNANCE}

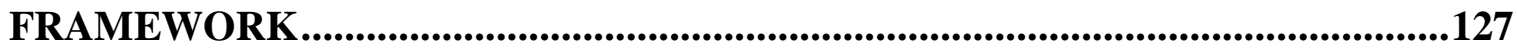

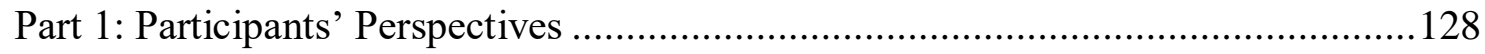

Section 1: Political Governance of Energy Security …......................................... 128

Section 2: Policies, Legislation and Institutions ............................................ 131

Section 3: Management of Energy Security .................................................. 141

Section 4: Government's Responses to Energy Security...................................... 149

Section 5: Best Approaches to Energy Security................................................ 153

Summary of Participants' Responses .......................................................... 161

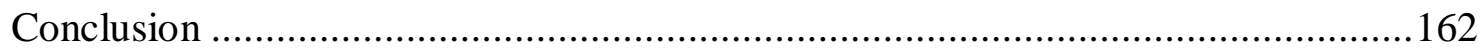

CHAPTER 7: THE CONTRIBUTION OF POLITICAL GOVERNANCE OF LIQUID FUELS TO ENERGY SECURITY IN PNG: A SYNTHESIS .................163

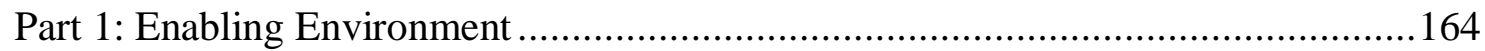

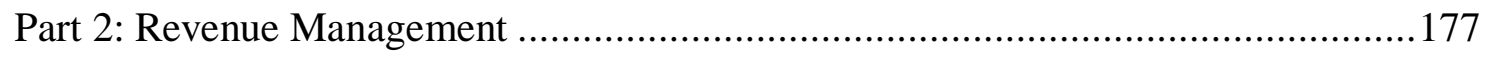




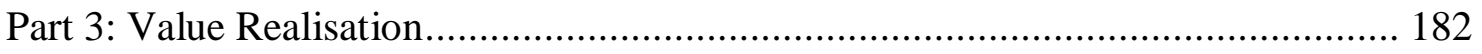

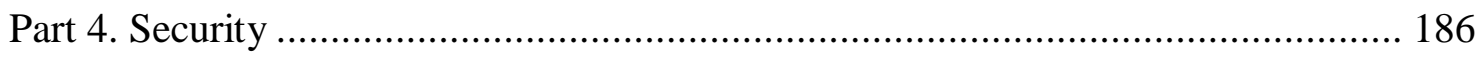

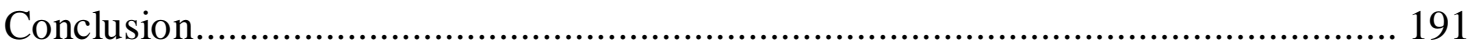

CHAPTER 8: IMPLICATIONS AND CONCLUSION ........................................ 193

Part 1: Implications to Public Policy Theory and Practice …................................. 195

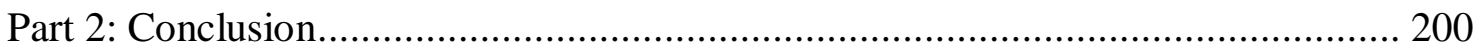

Part 3: Recommendations for Further Research................................................ 202

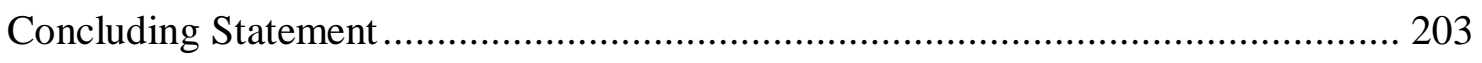

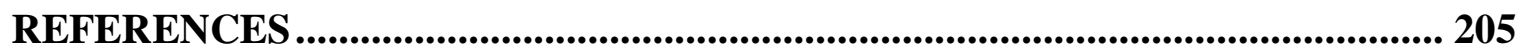

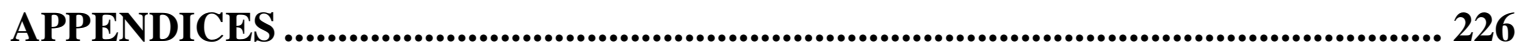




\section{Abbreviations or Acronyms}

AusAID

BSA

CSO

CSR

DFID

DMO

DPE

DPESI

EITI

FDI

GDP

GoPNG

IDA

IOGC

IPBC

KPHL

LNG

MNCs

MPE

MPESI

MTDP

NA
Australian Agency for International Development

Benefit Sharing Arrangement

Civil Society Organisations

Corporate Social Responsibility

Department for International Development

Domestic Market Obligation

Department of Energy and Petroleum

Department of Public Enterprises and State Investment

Extractive Industry Transparency Initiative

Foreign Direct Investment

Gross Domestic Product

Government of Papua New Guinea

International Development Agency

International Oil and Gas Company

Independent Public and Business Corporation

Kumul Petroleum Holdings Limited

Liquefied Natural Gas

Multinational Corporations

Ministry of Energy and petroleum

Ministry of Public Enterprises and State Investment

Medium Term Development Plan

National Alliance Party 


\begin{tabular}{|c|c|}
\hline NEC & National Executive Council \\
\hline NGDP & National Goals and Directive Principles \\
\hline NGO & Non-Government Organisations \\
\hline NOGC & National Oil and Gas Company \\
\hline NPC & National Petroleum Corporation \\
\hline OECD & Organisation for Economic Cooperation and Development \\
\hline OLIPAC & Organic Law on Integrity of Political Parties and Candidate \\
\hline OPEC & Organisation of Petroleum Exporting Countries \\
\hline PBT & Power-based Theory \\
\hline PNC & Peoples' National Congress Party \\
\hline PNG & Papua New Guinea \\
\hline PNGDSP & Papua New Guinea Development Strategic Plan \\
\hline PNGNEP & Papua New Guinea National Energy Policy \\
\hline PPL & Papua New Guinea Power Limited \\
\hline QEGF & Quality Energy Governance Framework \\
\hline $\mathrm{RS}$ & Rentier State \\
\hline RST & Rent-seeking Theory \\
\hline SoE & State-owned Enterprises \\
\hline STaRS & Strategy for Responsible Sustainable Development \\
\hline SWF & Sovereign Wealth Fund \\
\hline Tcf & Trillion Cubic Feet \\
\hline UBSA & Umbrella Benefit Sharing Agreement \\
\hline UN & United Nations \\
\hline
\end{tabular}


UNDP

USAID

WB
United Nations Development Program

United States Agency for International Development

World Bank 


\section{List of Figures, Tables, Appendices, Map and Pictures}

\section{Figures}

1. Quality Governance Framework for LNG Energy Governance. 46

2. Changes in Petroleum \& Energy Ministers under the Somare and O’Neill governments 51

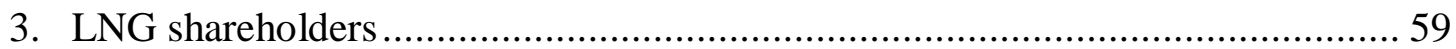

4. Proposed Kumul Consolidated Holdings structure............................................. 63

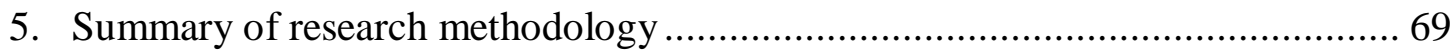

6. Timeline on petroleum and energy governance under Somare \& O’Neill governments from 2002-2017

\section{Tables}

1. Themes and subthemes and frequency of participants' responses 129

2. Themes and subthemes and frequency of participants' responses

3. Themes and subthemes and frequency of participants' responses

4. Themes and subthemes and frequency of participants' responses 150

5. Themes and subthemes and frequency of participants' responses 155

\section{Appendices}

1. List of Interviewees 227

2. Semi-structured Interview Guiding Questions ............................................ 229

3. Letter on Request for an Interview ............................................................ 232

4. Letter to the Participant's CEO (or Delegate) …............................................ 233

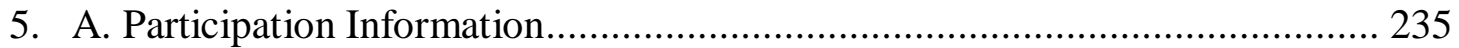

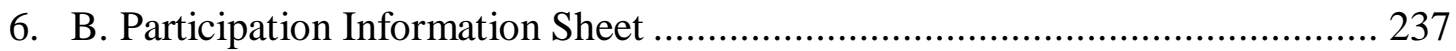

7. Policies, Legislation and Reports selected for Content and Thematic Analysis . 239

8. Codes of Participants 241

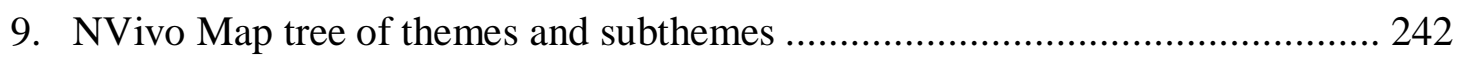

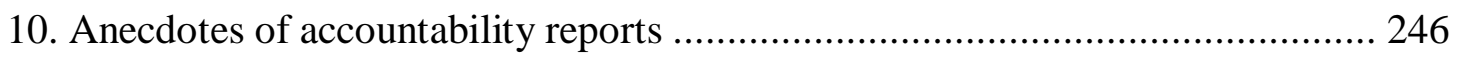

\section{Pictures}

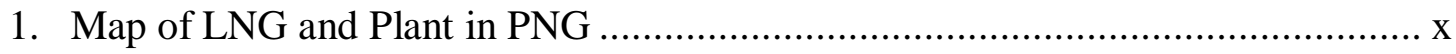


Picture 1. Map and Pictures of LNG and Plant in PNG

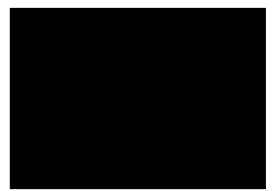

This content is unavailable.

Please consult the print version for access.

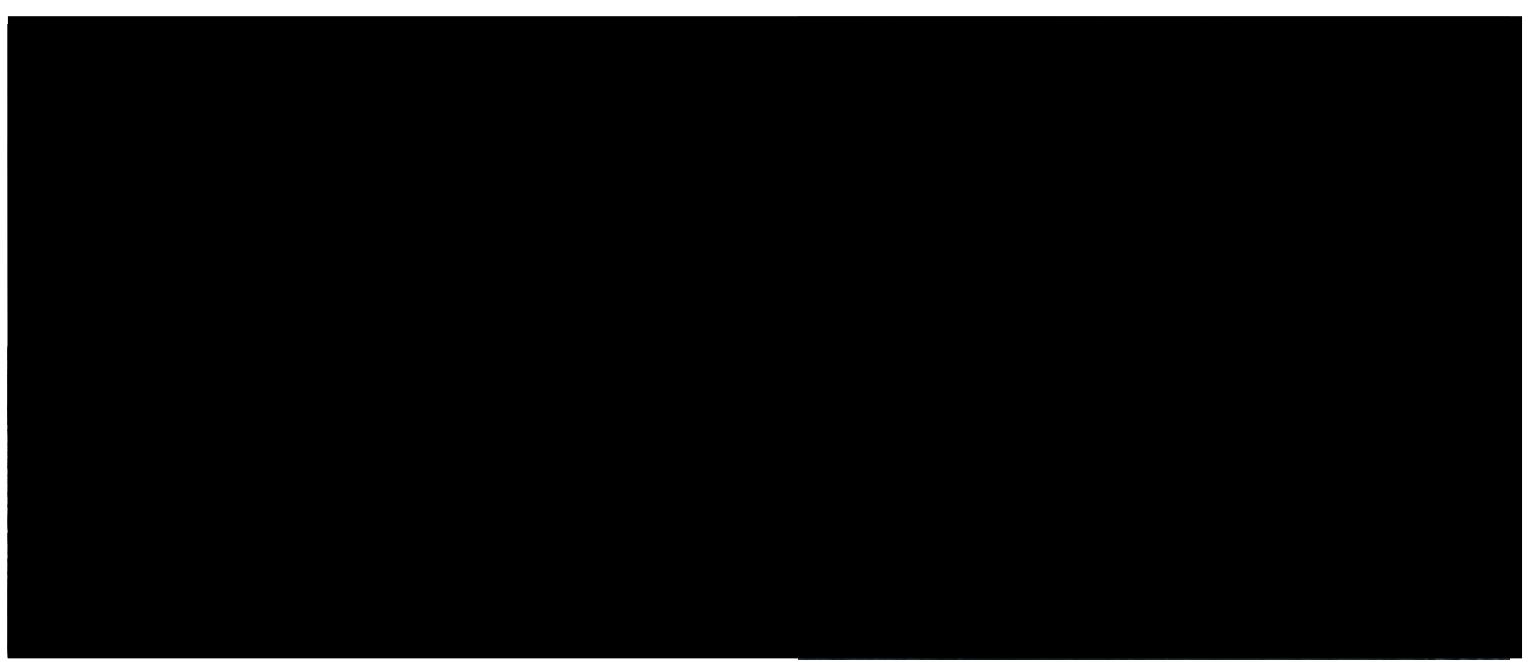

Source: (LNG World News staff, 2014) 


\section{CHAPTER 1: CONTEXT OF THE RESEARCH}

Governance of energy resources is a major policy problem in PNG's extractive industry. According to the Papua New Guinea Human Development Report of 2014 (PNGHDR), there has been little change in poverty levels in PNG despite a 40-year history dominated by the extractive industries and 14 consecutive years of economic growth (UNDP, 2015). The oil and liquid petroleum gas sector in PNG has been estimated by the Bank of Papua New Guinea to be worth at least K37 billion since 1992 (UNDP, 2015). Yet it is not uncommon for people in the PNG cities and the countryside to have no electricity. The statement from the PNGHDR 2014 underscores the need to better understand how in the availability of such richness from the extractive industries, which include oil for petroleum and natural gas, could have resulted in such unsatisfactory development outcomes in PNG. This same report found that the most pressing issue in PNG's extractive sector has been good governance, transparency and accountability in the management of resources.

This study examines how energy resources are governed in PNG and how that governance contributes to energy security. I am using the term 'governance' to refer to processes and outcomes of the interactions between actors (organisations, institutions, and indivduals). These processes may or may not observe formal rules, but they are not the rules themselves. Thus energy governance refers to the manner in which a set of formal and informal rules and institutions are used to shape political and economic behaviour in the energy sector to ensure long-term energy security for development. This definition is further elaborated in chapter three. Energy security is generally understood by many as the supply of and demand for energy in an energy market. As a multi-disciplinary concept shown in the literature (Chester, 2010), energy security ${ }^{1}$ is broadly defined as an object for security threats or as a subject generating or contributing to insecurity in society. Where the energy system is regarded as an object for security, threats are related to security of supply and security of demand; however, the energy system when defined as a subject could pose threats to human, national and societal security (Johansson, 2013). It is this latter subjective dimension that I am interested in and will discuss in Chapter three. Studies into energy security in PNG are rare yet essential to understanding how it affects development outcomes and national security. This study, therefore, is an important step towards

\footnotetext{
${ }^{1}$ It is important to note that security in the context of energy security refers to Johansson's (2013) definition, that is absence of threats or simply being secure. This will be used throughout the thesis.
} 
understanding the relationship between energy governance, energy security and development in resource-rich countries such as PNG (Barma, et al., 2012).

\section{A. Research Purpose and Questions}

The aim of this study is to explore how energy governance contributes to energy security in PNG. To achieve this aim, these key questions guided the research:

Main question:

1. How does governance of energy at institutional level contribute to energy security? Secondary questions:

Critical events in energy governance and energy security in PNG between 2002 and 2017 led me to the following subsidiary questions:

How has energy security been managed?

Have any actions been particularly successful in achieving energy security?

How might we improve governance of energy in terms of decision-making, policymaking and regulatory (legal) aspects of energy security?

\section{B. Scope and Approach}

This study is guided by a qualitative approach within a world view of social constructivism informed by interpretivism (Crotty, 1998). A critical case analysis based on content and thematic analysis have been used to explore political governance of liquid fuels from 2002 to 2017 based on critical events in energy governance which occurred within that period. Insights from a political economy framework are used to account for political interaction at the institutional level that affects energy governance and its contribution to the governance of energy security.

The findings are informed by documentary analysis and interviews with 20 participants from a number of institutions in the petroleum and energy and related sectors in PNG categorised as: state institutions (government agencies related to energy governance); regulatory institutions (government agencies that regulate energy); revenue-generating institutions (government agencies that manage LNG revenues and collect tax); producing institutions (IOGCs \& NOGC); Civil Society Organisations (including landowner 
associations); research institutions; and academia. The perspectives gained from these institutional actors provided an insight into understanding how energy (in the form of liquid fuels) is governed at political and policy levels and, in turn, how this governance affected development outcomes and contributed to energy security.

\section{Contribution of this Study}

Most studies on energy governance relating to energy security are found in developed and developing countries, in particular Africa, Latin/South America, Asia and the Pacific with more focus on renewable energy and global energy governance. I have found limited examples of the contribution of how energy governance has contributed to energy security in developing countries. For instance, few studies have been conducted on how weak government (political institutions) ${ }^{2}$ and political corruption in oil-rich countries have affected energy security. Much of the concentration has been on the international/political economy of energy, resource curse ${ }^{3}$, Dutch Disease ${ }^{45}$, renewable energy and global energy governance.

In PNG, others such as Kuwimb $(1997,2010)$ have studied the governance of mining and petroleum resources. Sovacool (2012) has focused on renewable energy, particular, solar

\footnotetext{
${ }^{2}$ In this thesis, I distinguish political institutions from institutions. Political institutions refer to organisations which create, enforce and apply laws. They often mediate conflict, make (governmental) policy on the economy and social systems and otherwise provide representation for the populace (Boddy-Evans, 2017). The concept of an institution on the other hand, generally refers to a set of formal rules (including constitutions), informal norms, or shared understandings that constrain and prescribe political actors' interactions with one another. Institutions are generated and enforced by both state and nonstate actors, such as professional and accreditation bodies. Within institutional frameworks, political actors may have more or less freedom to pursue and develop their individual preferences and tastes (Gilad, 2018). In this thesis, I refer to political institutions as governments or ruling governments, political parties, and politicians (political actors). My focus is on political dimensions of public policy. That is how political institutions influence public policy through institutions in PNG.

${ }^{3}$ The paradox remains that countries with an abundance of natural resources, specifically non-renewable resources like minerals and fuels, tend to have less economic growth and worse development outcomes than countries with fewer natural resources (NRGI, 2015 \& 2018).

${ }^{4}$ In resource-rich countries, increases in oil, gas and mineral exports to foreign markets can generate large capital inflow, resulting in real exchange rate appreciation and inflation. This can hurt certain parts of the economy — such as manufacturing - and make exports less competitive (NRGI, 2015 \& 2018).

${ }^{5}$ Where a blessing is expected from natural resources in developed countries, the resource curse appears to be a trap in many of the developing countries. Resource curse often leads to Dutch Disease where it displaces and diminishes the agriculture sector and manufacturing industry, which are associated with economic growth and technology. PNG seems to experience this syndrome (Avalos et al., 2015). One of the contributing factors of a curse and symptoms of Dutch Disease is poor governance and corruption. However, only a few countries such as Norway have managed to escape the syndrome of the resource curse and Dutch Disease due to its quality policy regime (Sacks and Warner, 2001).
} 
energy with an implicit emphasis on energy security. There is scant literature that focuses particularly on how political governance of liquid fuels contributes to energy security in PNG and Pacific. This study is positioned to produce fresh theoretical and practical insights into energy security and public policy.

In so doing, the research makes a contribution to the understanding of energy security and public policy. That is, the study contributes to our understanding of how governance of energy, in particular LNG policies and legislation at the institutional level, contributes to energy security in a resource-rich country such as PNG. Although the current study is based on a small sample of participants, by utilising relevant core qualities identified in the Resource Governance Index used in the analysis of data, the findings have demonstrated that there is a clear link between governance, energy and security.

While many studies, particularly in the fields of economics and political science, have quantitatively and qualitatively focused on the causal relationship between resource curse/Dutch Disease, and conflict and wars in oil-rich developing countries, very little has been investigated about the possible link between governance and energy security.

This study has demonstrated that governance of energy could lead to negative development outcomes and, therefore, impinge upon national security. In so doing, it makes a valuable contribution to the existing body of research related to energy security and forges a link between political science, economics, public policy, energy, and security.

This study also helps contribute towards improving energy governance in PNG as one of the resource-rich countries in the Pacific currently struggling with the syndrome of 'paradox of plenty'. In common with many other developing countries, PNG is not immune to the natural resource problem of resource curse and Dutch Disease. The country has a problem of prudently managing revenues from the resource sector, in this case, LNG. This study provides an insight on how best revenues should be managed politically at the institutional level.

Finally, this study also provides a fresh horizon for research in the area of energy security, especially in the area of governance of renewable energy and qualities of energy by combining both qualitative and quantitative studies to understand energy security. 


\section{Ethical Considerations}

Ethics in research is important to maintain the credibility of the research and to access sensitive data (Creswell, 2014). Before proceeding with this research, I applied to the University of Victoria Human Ethics Committee for approval to conduct this study outside of New Zealand. In accordance with the guidelines of the Ethics Committee, approval was granted based on the condition that consent from participants was obtained. The Human Ethics Approval number accorded to this study is 0000023724 (Pipitea Subcommittee).

This thesis involved interviews with policymakers and members of civil society groups. These people were offered confidentiality as part of their consent to participate. Therefore, confidentiality remains paramount in order to adhere to the research ethics committee's approval. Furthermore, the purpose of the study was explained to the participants for them to understand the nature of the topic in order to secure their consent. In so doing, an ethical relationship was established; for instance, in the explanation of accurate information about the nature of the study and what would occur during and afterwards.

\section{E. My Place in this Research}

Research is driven by one's worldview of an existing or emerging problem in society and one's motivation. Of relevance to this study, my worldview and motivation have been shaped by my upbringing as a native PNG citizen and my roles in the PNG government sector.

Firstly, I found myself curious as to why PNG, a country blessed with natural resources, is still lagging behind in its development, while other developing countries in the region with relatively fewer resources have made rapid progress. Whilst working as a public servant in PNG, I have travelled in Asia and noticed that some of these countries utilise scarce resources at their disposal and emerge from poverty to become developed economies. Even a Small State Developing Island Country such as the Maldives, made up of isles floating on the heart of the Indian Ocean, does better than PNG in development indicators as a middle-income economy. Even more puzzling is the fact that, despite some of these countries sharing the challenges of immature governance institutions and corruption, they tend to do better than PNG. The immediate question in my mind is, why is PNG not achieving better development outcomes for its people? 
Secondly, I became interested in energy security after experiencing the legacy issue of energy poverty in PNG in many ways. PNG is an energy rich country in terms of renewable and non-renewable energy sources. Despite producing and exporting oil and LNG to global markets, she continues to experience power interruptions (power blackouts) in major cities. It is disappointing to see residents, even oil and LNG landowners, lacking access to electricity, when it was supposed to be provided or met by those in authority. Instead of PNG being self-sufficient, she tends to import more than export energy related products, therefore, impairing an industrialisation progress that has not yet met expectations. I was left to puzzle, why is it that PNG continues to face energy poverty?

Moreover, while working in the higher education sector, I have been curious about why the government has not been investing more in human capital given the rents it acquires from petroleum exports. Why is it that strategic areas such as human capital development have not been given priority, other than in the mining and petroleum sector, by the government?

Finally, the project was conceived during my time working for the government. As a policy advisor in the higher education sector, I was provoked by the issue of PNG being plagued with systemic corruption. Why is it that PNG behaves differently from other countries of similar geography and colonial history? Is there something that we may have missed in understanding the underlying problem?

These questions, in many ways, have fundamentally motivated my interest in studying energy security and how it links to the issues of development and national security. I have observed generally that energy security is a comprehensive subject of interest that may shed light on these thought-provoking questions. I arrived at a preliminary hypothesis that suggests the manner in which energy security has been approached will provide fresh insights into understanding why PNG has experienced a different development pattern.

\section{F. Organisation of the Thesis}

The thesis has eight chapters. The first chapter introduces the research in terms of the purpose and questions, significance, motivation, scope, knowledge contribution, and ethics. Chapter two lays out the literature review strategy. It establishes a definition of energy security and energy governanceand provides a critical focus on the literature on energy security; empirical and theoretical contributions of energy governance. A knowledge gap 
is identified and together with an overview of the concept of ownership contributes to the theoretical framing of an energy governance framework with which this chapter concludes. This chapter is followed by the background to PNG's development status and the emergence of its energy governance structures and institutions. This frames the setting of the energy sector, institutions, policies and legislation and key players and their interests.

Chapter four describes the methodology, research strategy, research design and methods applied in the research. Chapter five presents the LNG energy governance framework, while the implementation of the LNG Energy Governance follows in chapter six. Chapter seven discusses and synthesises chapters five and six. This chapter establishes how the political governance of LNG energy has contributed to energy security in PNG. The final chapter discusses the theoretical and policy implications, proposes areas for further research and concludes with a summary of the research. 


\section{CHAPTER 2: LITERATURE REVIEW}

Chapter two presents a review of selected literature relevant to energy governance and energy security and adopts an appropriate theoretical framework for the study in the PNG context. The chapter is divided into nine parts. The first part sets out the literature review strategy. The second part introduces the definitions of energy security and energy governance. The third part is a survey of the scholarly field of energy security. The fourth part gives an overview of international experiences about energy security and focuses, in particular on Organisation for Economic Cooperation and Development (OECD) countries, including resource-rich developing countries. The fifth part builds on part three and discusses some empirical and theoretical contributions from scholarship concerning the governance of energy security in developing countries and PNG. The sixth part is a summary of governance and accountability reports. The seventh part is an overview of the theory and concept used in conceptualising energy security. The eight part discusses a knowledge gap of importance to this research. The last part draws on the threads of this literature platform to identify a governance framework for use in the analytical and discussion phases of the research. The uniting focus across these parts is energy governance and of its contribution to the governance of energy security.

\section{Part 1. Review Strategy}

The review involves a survey of existing contributions on energy security and governance of energy security in OECD and resource-rich developing countries. This involves conducting a historical survey of the existing body of knowledge in this field through books, peer-reviewed journals identified through search engines, such as the Journal of Energy, Journal of Energy Economics, Extractive Industries and Society Journal, Comparative Economic Studies Comparative Political Studies Geo-Journal, Resources Policy Journal, The Pacific Review, Journal of Development Economics, World Development, JSTOR, SAGA, and others, articles from recommended sites, Google Scholar and grey literature such as Working Papers. Two search foci have been used to survey the literature: energy security and energy governance in resource-rich developing countries, together with energy security and energy governance in PNG. The objective of the search was to refine the focus for my research by clarifying our understanding of the 
governance of energy security in resource-rich developing countries (Feak, 2009) and identifying any gaps in the existing literature.

\section{Part 2. Definitions of Energy Security and Energy Governance}

\section{A. Energy Security}

Energy security is a multidisciplinary concept with no unified or universal definition (Chester, 2010). Yergin (2006) defines it as an umbrella term linking energy, economic growth, and political power by locating one's conception in the value chain from a political economic perspective. Others such as APERC (2007) define it as one that constitutes four As (accessibility, affordability, availability, and acceptability). However, Cherp \& Jewell (2014) suggest that the 4As definition does not address the security question and define it otherwise as 5As (availability, accessibility, accommodation, affordability, and acceptability). Following on from the 5As, these same scholars define it as a low vulnerability of vital systems. While a debate exists regarding a precise definition of energy security, the stance adopted in this thesis is that energy security should be defined in the context in which it is used. Hence, Johansson's (2013) conception is relevant in that he suggests that energy security might be studied as either an object of security or a subject of security. The former refers to the security of supply and security of demand. Some examples of security of supply include critical infrastructure protection, availability of energy sources and supply-demand matching. Examples of security of demand include protection of market share and stable cash flow. Energy security as a subject, on the other hand, refers to those structures, actions, processes or outcomes that generate or enhance security or enhance insecurity. Examples of this definition are mainly political-economic risk factors, technological risk factors, and environmental risk factors. Political-economic risk factors include the struggle for scarce resources and exercising power through energy dependencies; whilst technological risk factors include dam safety, nuclear materials, oil tankers and gas explosivity. Lastly, environmental risk factors include climate change, air and water pollution, and threats to biodiversity. However, according to Johansson (2013), there is no clear-cut division between various elements of these typologies and some threats could be classified as belonging to more than one of the defined groups.

In this thesis, energy security is focused on as a 'generator of insecurity' or as an 'enhancer of insecurity' or, conversely, it can also be an enhancer of 'security' (increase the level of being secure from threats) in society. That is, energy security refers to structures, actions, 
processes or outcomes that can generate or heighten insecurity or conversely heighten or enhance security. An example would be a weak law that provides the potential for corruption thereby generating or enhancing energy insecurity. Energy security, on the other hand, enhances security in society. A good example of this would be that a strong tax law prevents or limits opportunities for tax avoidance and evasion thereby enhancing (strengthening) energy security. This focus fits well with PNG's context for governance of energy security in which energy richness is accompanied by energy deficits. This focus on energy security leads to consideration of the underlying problems associated with resourcerich countries. These include uneven distribution of wealth, corruption and reduced incentives to build functioning institutions associated with resource curse as contributors to energy security based on Johansson's definition.

\section{B. Energy Governance}

Governance is a general term that could be used in different contexts such as the governing of the government (how the government governs the economy and society through its established political system), or corporate governance in business organisations. It is used extensively by scholars in various fields (Kjær, 2004). For example, Folke and others define it broadly as 'structures and processes by which people in societies make decisions, set rules, and share power' (2012).

In recent decades development partners of newer nations such as PNG have emphasised the need for good governance, particularly in contexts where the perception has been that poor governance has resulted in economic decline and potential state failure. The United Nations Development Program (UNDP), for instance, defines governance in modern terms as:

"The exercise of political, economic and administrative authority to manage a nation's affairs. It is the complex mechanisms, processes and institutions through which citizens and groups articulate their interests, exercise their legal rights and obligations and mediate their differences" (UNDP, 1997). 
The World Bank (WB) initially defined governance in terms of transparent processes and accountability to ensure that activities of governments are closely scrutinised by the parliament, media and civil society. In the 1990s, the WB further identified 'good' governance in the context of 'sound development management' (1992) which is linked to the concept of 'new public management' in public administration and public sector reform (Hudson, 2014; Turner, 1997). Hyden (2004) defines governance as '... the formation and stewardship of the formal and informal rules that regulate the public realm, the arena in which state, as well as economic and societal actors, interact to make decisions' (Hudson, 2014: 12).

These definitions do not take into account the interaction of political actors with the process of governance. The International Development Agencies (IDAs) argue that poverty in developing countries boils down to politics of how to govern the economy and society. From this perspective, Unites States Agency for International Development (USDFID) (2001) then extended WB's definition of governance, this time, with clarity about the role of political actors in the process:

\begin{abstract}
'We use the term governance to mean how the institutions, rules and systems of the state - the executive, legislature, judiciary and military - operate at the central and local level and how the state relates to individual citizens, civil society and the private sector. We use government to mean the executive function at central and local levels. The political system or politics is the way power in the state is acquired and how people and groups inside and outside government influence the use of that power'(USDFID, 2001:11)
\end{abstract}

Understanding governance from a political perspective is one critical way of fighting poverty. This point was well articulated by Hilary Benn, whilst the UK Secretary of State for International Development, 'Ultimately it will be politics that will help us make poverty history' (Benn, 2006 in Hudson, 2014: 13). DFID affirmed this definition that '[Governance] is about politics. Politics determines how resources are used and policies are made. And politics determines who benefits. In short, good governance is about good politics' (USDFID, 2006; Hudson, 2014). In recent times, AusAID, too, has come to define 
governance through the lens of political science with this bold statement: 'development is an inherently political process' (AusAID, 2011; Hudson, 2014). In its 2015 Report, the Australian Department of Foreign Affairs and Trade (DFAT) further strengthened this definition by asserting that governance is 'how power and authority are used to manage a country's resources ... and 'governance' is also used to describe a sector' (ADFAT, 2015:3).

Similarly, energy governance is defined broadly since it concerns multiple policy fields ranging from politics, economics to environment where issues are global and relatively cross-cutting. According to the definition provided by Fontaine (2011), energy governance refers to the system of the energy-related interplays between the state, society, and the economy. Lesage (2010) defines energy governance in the context of peak oil production and the shifting geography of supply. Energy governance also resonates with the international political economy of oil and gas where geopolitics matter (Yergin, 2006). Some governance scholars have recently adopted the term 'mega-issue' particularly in respect of how power and policy are dynamically managed (Lesage, 2010).

In order to establish the link between governance and energy security, I argue that energy governance can be seen as a set of rules, both formal and informal, and institutions that constrain political and economic behaviour in the energy sector to ensure long-term energy security for development.

Studies of energy security initially emerged in response to separate policy agendas such as the supply of fuels for armies and transportation, uninterrupted provision of electricity, and ensuring market and investment effectiveness (Cherp \& Jewell, 2011). More recently, it has become a distinct scholarly field incorporating traditional and modern interdisciplinary fields in addressing the energy policy agenda (Sovacool, 2014; Sovacool \& Mukherjee, 2011).

Moreover, energy security studies in the $20^{\text {th }}$ and $21^{\text {st }}$ centuries are heavily concentrated on the supply side and rooted in political science and related disciplines such as public policy, security theories, international relations and global governance. Three perspectives from political science, economics, and natural/technical sciences dominate the scholarship on energy security (Cherp \& Jewell, 2011), which are fundamental to the following analysis of the energy security literature. 


\section{Part 3: A Survey of Energy Security Literature}

Research into energy security has a long history. Over the last two decades, there has been growing research into establishing and understanding the relationship between energy and security from various disciplines. Many scholars have argued that energy security is a multi-disciplinary field with no clear perspective, overlapping with engineering and energy systems analysis, earth sciences, economics, technology studies, political science, international relations, security and military studies (Cherp \& Mukhtarov, 2014).

Here, therefore, energy security is surveyed as a field of study from two different perspectives, the traditional and contemporary.

\section{A. The Traditional Perspective}

Energy security was first linked to historical challenges in the $20^{\text {th }}$ century. The focus of the literature was on the nexus between energy and national security during WWI and WWII. The first serious discussions were around the challenges and policy implications of the security of oil supplies to feed warships and vehicles. Some of the examples of comprehensive research in this conversation include Yergin, (1991) and Sagan (1988). These studies are important to understand how energy security first evolved as a topic of scholarship.

About 30 years on from the publication of these studies, the focus of energy security shifted to vulnerability from oil shocks due to fluctuation in demand and supply of oil for civil transportation and electricity triggered by global economic changes. Much of the research in the 1970s was on domestic policy and international regimes. These studies are widely captured in political science and international relations literature such as Paust and Blaustein (1974), Krasner (1978), and Ikenberry (1986). The sovereignty perspective developed by Cherp and Jewell (2011) is built around this conversation and is further expounded by Hughes and Lipscy (2013). These studies exemplify the strategic significance of oil supply in warfare and oil shocks in understanding why states went to war and how the global energy market affects society. 


\section{B. The Contemporary Perspective}

The second discourse on energy security is based on the contemporary operationalisation of energy security. Around the 1990s and 2000s, there was a turn of conversation from the traditional oil supply to other aspects of energy security, which gave rise to various conceptualisations, operationalisations, and measurements of energy concerns. A body of research began to emerge linking security with natural gas, nuclear energy, electricity grids and other types of vulnerabilities originating in political, economic, technical, and natural factors (Yergin \& Frei, 2006; Yergin, 1998). These studies generally argue that energy security should be approached comprehensively, taking into account other important factors. Two scholarly traditions emerged from this perspective, one from social science and the other from science. In the former, 'dimensions' of energy security based on stakeholder opinions attracted a wider context capturing a broad view of environmental, social and other related aspects (Sovacool, 2011). Using this approach, Chester (2010) expanded this tradition by introducing the concept of "polysemic" which refers to definitions or concepts from different contexts of energy security. He argued that the energy security concept is loosely defined, because it has different meanings in different contexts and for different audiences. Cherp and Jewell (2011) view energy security as a politically constructed concept rooted in properties of energy systems and governing institutions which have distinct policy problems and approaches. The latter tradition studies the science of energy security. This study is based on engineering and economics focusing on properties of energy system; For instance, measuring heat in terms of electricity (Winzer, 2012).

Thirdly, a number of scientific studies from policy think tanks and governments have begun to measure energy security using different approaches and methodologies, in particular on how to operationalize and measure energy security as a political factor. Kendell (1998) shows the importance of measurement in energy security related to oil import dependence and vulnerability. Bazilian et al. (2009) advances this quantitative analysis with a more complex method of measuring electricity systems. Using the same methodology, Scheepers et al. (2007) and Kruyt et al. (2009) propose systematic systems of indicators for energy security that relate to availability (elements relating to geological existence), accessibility (geopolitical elements), affordability (economical elements) and acceptability of energy (environmental and societal elements). Others, such as the International Energy Agency (IEA), proposed and used a method for evaluating the security of primary energy sources 
in OECD countries based on the assessment of internal and external risks and vulnerabilities for eight different fuels and carriers (Jewell, 2011). Some writers, however, (e.g. Cherp \& Jewell, 2013 and Gracceva, 2014) have attempted to draw fine distinctions between indicators and frameworks and argue that energy security should be assessed using quantitative systematic assessment frameworks rather than separate indicators. The other focus of contemporary energy security literature is on an alternative discourse around energy security as a political concept. This literature is rooted in classic political science theories such as the securitisation theory (Buzan et al., 1998) and new institutionalism (Cherp \& Mukhtarov, 2017). Helm (2002) supports this view by explaining how energy was securitised in the UK in the 1980s and the 1990s due to competing political interests and ideas relating to coal strikes emanating from energy market liberalisation and underinvestment in power generation capacities and how political discourse linked interpretations of energy security with ideas of competitiveness and sustainability respectively. But others (see Chester, 2010 and Kern et al., 2013) argue that energy security has different meanings in different contexts and further explain a paradigm shift based on recent developments of energy security interpretations in the UK. Meanwhile, Cheon and Urpelainen (2014) argue that energy security is more of a political problem, based on their assessment of how Western countries responded to the oil supply shocks of the 1970s by investing in energy.

Beyond these political concepts is the literature on energy security and international relations. The focus of this literature is the discourse around how oil shocks affect international relations. According to Hancock and Vivoda (2014), the 1970s oil shocks contributed to the revival of the political economy of international energy relations. This view is supported by Yergin (2006), Victor and Yueh (2010) who maintain that the oil shock episode gave rise to many scholarly contributions in prominent foreign policy journals. In recent years, there has been an increasing amount of literature on how international relations are affected by energy security, for instance, the EU-Russia's relations (Kuzemko, 2014; Stegen, 2011) and the US-China relations (Downs, 1999; Zweig, 2005; Nyman, 2014).

A related discourse is the security and geopolitics of oil. The central focus of this literature is a conversation on the relationship between energy security and geopolitics with regard to oil. It has at its heart concerns about global energy security, as a response to the World Wars and an oil embargo when the Organisation for Petroleum Exporting Countries 
(OPEC) imposed an embargo upon the US in retaliation for the US decision to resupply the Israeli military and gain leverage in the post-war peace negotiation. This conversation was also taking place alongside research arguing that conventional oil would inevitably peak in the first half of the 21st century (Campbell, 2012). The peak oil concept, however, is still debatable in light of the discovery of unconventional resources (e.g. oil shale) in North America (Hughes \& Rudolph, 2011; Rogner et al., 2012) and elsewhere. Some authors have mainly been interested in questions concerning the appetite for scarce resources by new consumers such as China (Leung, 2011) and resource wars (Klare, 2002). In his book, Klare (2002) predicts that if this trend continues it may lead to the breakdown of the oil market and 'resource wars'. However, this view has been criticised by others such as Jaffe et al. (2008) who argue that market forces and government intervention had prevented wars and global instability. Karl (1997) further contends that the abundance of oil resources may impede the spread of democracy and stimulate conflict and political instability in lowincome countries.

Furthermore, in recent years, the security and geopolitics of natural gas have attracted scholarly attention. In his study, Reymond (2007) raises concerns over global gas resources, increasing demand, and the geographic concentration of production due to the interruptions of Russian gas supply to Ukraine in the mid-2000s. Other scholars have focused their interests on exploring the vulnerability of European countries to natural gas supply (Söderbergh et al., 2008), analysis of potential geopolitical risks associated with Russia (Larsson, 2006) and relationships between Russia and European countries (Goldthau, 2008; Smith, 2011). They argue that Russia would use energy as a weapon to disrupt gas supply to achieve political concessions from the European Union. This is against a European supply of energy that Stevens (2010) argues in his analysis is unlikely to repeat the US shale gas revolution in Europe.

In recent years, there has been an increasing amount of literature on the security of other energy sources and energy infrastructure, in particular, security of coal, biofuels and refined oil products, nuclear energy, hydroelectricity, biomass, electricity supply and end-uses in transport, industry and the residential sector. While a focus on the security of oil and natural gas has been dominant in contemporary energy security, the security of other energy sources also attracts the attention of policy makers and scholars. A few studies consider other sources of energy as important to energy security. For instance, Cherp et al. (2012) focus on a wide range of vulnerabilities ranging from demand growth and aging of 
infrastructure to blackouts induced by natural events and technological dependencies in nuclear energy. Similarly, Jewell (2011) applies an IEA short-term model to identify risks and vulnerabilities of oil and its products, natural gas, coal, biomass and waste, renewables (solar, wind, geothermal, hydropower, and ocean energy) and nuclear power. These studies suggest that energy security with respect to each of these products should be studied comprehensively.

The OECD National Energy Agency Report (2010) on measuring energy security discusses the relationship between coal security and energy security by building on the earlier work of Scheepers (2007). See also Kessels (2008) on coal energy. Johansson (2013) further provides an overview of energy security risks associated with new renewables (solar and wind), whilst Morey and Kirsch (2014) and Grave (2012) raise caution about renewable electricity. On the other hand, Lilliestam and Ellenbeck (2011) in their analysis of imported renewable electricity for Europe found no significant risks. Grave et al. (2012) support this argument through an engineering analysis of a case in Germany. Kessels et al. (2008) discuss in further detail the potential issues associated with security of coal supply.

Deriving from other sources of energy security is the literature on security of electricity. This literature focuses on the engineering and economic aspects of electricity generation. In their analysis, Lovins and Lovins (1982) argue that centralised electricity supply systems are far more vulnerable than distributed generation from small-scale renewable sources. Stirling (1994), Awerbuch (1995) and Bazilian and Roques (2009) discuss the security of electricity based on the liberalisation of electricity in the UK. Farrell et al. (2004) analyse the vulnerability of energy infrastructure, including electricity systems. The Electricity Journal (2013) discusses electricity blackouts and their effects. Dobson et al (2007) discuss how complexity system theory could be applied to explaining why blackouts occur and persist in complex liberalised electricity systems. However, Yu and Pollitt (2009) did not find an empirical link between blackouts and electricity market liberalisation.

Finally, the literature on energy security and climate change mitigation has recently attracted attention. The focus of the literature is the nexus between energy security and climate change, in particular on climate change mitigation policies. The discourse centres on the debate between energy security and climate change in the context of political, institutional and legal environments (Froggat et al. 2013; Bazilian et al., 2011; Rosen, 2009). Jewell $(2013,2014)$ analyses the short-term climate change mitigation scenarios. 
While Bollen et al. (2010) and McCollum et al. (2014) calculate the "energy security cobenefits" of climate mitigation policies with a single metric of energy security, Gracceva and Zeniewski (2014) discuss the energy security implications of climate change mitigation in the EU.

Generally, these studies have not only shown that energy security is a comprehensive and multi-disciplinary topic in its own right but also assisted in locating my place of research. In this survey, I was not able to establish a clear understanding of the link between governance of energy and security in developing countries. Having discussed the field of energy security and its contributions, I will now move on to discuss some of the international experiences of energy security.

\section{Part 4. Energy Security in OECD Countries and Resource-Rich Developing Countries}

I commence with a focus on energy security in OECD counties and follow this with the discussion of the application of the concept to resource-rich developing countries.

\section{A. An overview of energy security in OECD countries}

The literature on energy security in OECD countries focuses particularly on geopolitics, economics, and environmental dimensions. The OECD was established alongside the IEA as complementary organisations to address the socio-economic development and energy security of western countries in the 1970s in response to OPEC embargo (Bamberger, 2004; Scott, 1994).

Studies show that energy security has become a top policy priority in OECD (e.g. Chester, 2009). Despite being the second largest producer and consumer of energy in the global economy (IEA, 2014, 2017), OECD countries are also susceptible to energy security due to uncertainty in the energy markets that is caused largely by instability in the middle-east oil-producing states, the monopoly of oil production by OPEC and natural disasters (Gnansounou, 2009; IEA, 2017, 2018; Gupta, 2008). Supply of energy (security of oil supply) has been a major concern for many of the member countries because they are depending more on imported oil and gas to feed domestic demand (Murakami et al., 2011; Cohen et al., 2011). 
A couple of factors have caused an increasing demand for energy sources overseas, especially in developing countries, Middle-East, South and North America, Russia and Eastern Europe (IEA, 2017). One such factor is that some of the OECD countries have done little to diversify their energy since the first oil crisis and the formation of IEA (Murakami et al., 2011). Another factor is the intensity of industrialisation and the revolution in transportation, electricity and technology in Europe, North America, and OceaniaAustralasia that has pushed governments to further look for overseas partners through cooperation and collaboration for investments (IEA, 2014).

Several studies have shown that OECD countries, in response to declining hydrocarbon reserves, increasing demand for energy by emerging economies such as China and climate change have shifted their policy focus towards promoting energy efficiency by investing in clean energy while maintaining a considerable import dependence policy (John, 2002; OECD/EA, 2013). Through this shift, they are contributing towards mitigating carbon emissions (Butlera \& Parkhillb, 2018; IEA, 2010; OECD, 2007). In the face of climate change, some of the member economies such as US and Australia who are also the biggest LNG exporters have not remained committed to global energy governance (O’Neill, 2016). One possible reason could be more economical and geopolitical. That is, advanced countries need oil to remain geo-economically competitive in order to sustain their global political leadership against China's rising influence (Goldthau \& Martin, 2010).

Another group of studies has shown that developed countries in Europe, such as the UK and the Netherlands, suffer from resource curse and Dutch Disease as a result of weak governance in oil and gas industries (Frynas, 2010). However, these studies also suggest that countries who are members of the EITI have not been fully committed to the principles of resource governance. For instance, the general practice of corporate social responsibility (CSR) in the petroleum energy industry in Australia has been a problem due to lack of government regulation on multinational corporations (MNC) (Paynter et al., 2018). This has been an ongoing challenge for OECD countries (EY, 2014; DEITi, 2016). One of the major problems found in the developed countries has been corruption, in particular in petroleum and electricity industries where large contracts and transactions take place (Andrew, 2014; EY, 2014).

There is a consensus among scholars that there are some interesting yet noble lessons for developing countries, especially resource-rich nations, on the governance of natural 
resources that can be learned from OCED countries. Norway, a European country, is a leader in petroleum management that has set the international benchmark in energy governance. The success of Norway in establishing effective energy policies and legislation has become known as the 'Norwegian model', with clear separation of policy, regulation, commercial functions (for example, Thurber, 2011; Holden, 2013; IEA, 2011) and revenue management through a savings and stabilisation fund (e.g., Velculescu, 2008; Skancke, 2003)that has been embraced internationally.

Various studies have assessed the efficacy of the Norwegian model and suggested that the OECD countries could also learn from Norway. For instance, a study by Hunter (2010) argues that the present Australian petroleum regulatory framework shows no occurrence of optimal extraction; that petroleum legislation provides little capacity to regulate petroleum industry and fails to encourage the maximisation of the value of Australian petroleum for the benefit of the Australians. Other studies suggested improving the energy governance framework by removing the existing barriers (Schultz \& Sharpe, 2014; Commonwealth of Australia, 2009).

Energy security remains a challenge in OECD countries despite them being the largest energy exporters and importers in the global economy due to geopolitical, economic and environmental concerns. Studies generally caution that governance strategies that work well in countries with mature institutions may be ill-suited to countries lacking certain institutional endowments (e.g. Grindle, 2004, 2007; Thurber, et al., 2011; Moore \& Putzel, 1999; Rodrik, 2008). Taken together, the studies in this section show that the link between petroleum energy governance and energy security is under researched.

\section{B. Energy Security in Resource-Rich Developing Countries}

Energy security issues in developing countries are discussed in this section. The notion of energy security in developing countries is clearly concerned with the security and insecurity of the supply and demand of energy (Cherp \& Jewell, 2011; Yergin, 1988, 2006; Kuik et al., 2011). First, security of supply is a traditional issue that affects developing countries based on the fact that many of them lack the capacity and technology to convert their rich energy sources (both renewable and non-renewable) into secondary and finished products to feed the domestic population (Cherp \& Jewell, 2011; Jewell, 2011; Sovacool, 2013; 
Sovacool et al., 2011; Yergin, 1988). Given this condition, governments tend to depend highly on imported energy from developed countries to feed and sustain the energy appetite of the domestic population. For instance, government and businesses depend very much on electricity to sustain their daily operations. This dependence usually comes with a high opportunity cost to sustain the economy. Failure to achieve energy security and consequential disruption of electricity supply has a significant impact on the economy and population.

Secondly, security of demand is increasingly becoming a major problem in resourcedependent economies (Cherp \& Jewell, 2011; Yergin, 1988, 2006). As these countries begin to export more of their energy sources, usually in the form of primary unrefined products, the country tends to depend more on revenues from these exports to sustain the economy. This pattern conditions the government to become highly dependent on energy revenues and in turn makes the country highly vulnerable to exogenous economic shocks caused by market forces in the global economy such as perturbations in oil demand and supply.

Similarly, the balance of payments between imports and exports often appears to be in disequilibrium. Resource-dependent countries import more energy than they export. As a result, a significant amount of their revenues earned from export is often spent on import. Any profit earned from export remains relatively marginal and therefore, the country remains trapped in poverty (Barma et al., 2012, Yergin 1988).

The two issues identified above point to the issue of energy governance. Existing literature suggests that resource-dependent economies tend to be more vulnerable to weak governance and high-level corruption which often leads to poverty, conflict, violence, and civil war (Klare, 2001a, 2001b, 2016; Klare, 2004a, 2004b, 2008; McNeish, 2010). Some scholars refer to it as 'resource wars' based on a general consensus of different terminologies and theories. They argue that an abundance of natural resources is frequently at the root of violent internal and border conflict (Collier 2005; Kaldor 1999; Kaplan 1994; Nafzinger \& Auvinen 1996; Watts 2008). This notion is generally accepted as the paradox of plenty (Karl, 1997). Under these circumstances, the government becomes progressively weaker and repressive as it seeks to exploit rents from the energy sources at the expense of the society as a whole. In the process of building a rent-seeking network, it develops policies and laws that are often biased, thus socially creating a weak society and increasing 
poverty. Recent research by Keating and Brown (2015) found that resource disputes can also trigger violence and destruction, particularly in states with weak governance, high levels of corruption, and existing ethnic and political divisions.

This political culture is systematically entrenched and becomes more and more likely to be associated with the phenomenon which has been labelled a 'resource curse' and 'Dutch Disease' making oblique reference to the plight of a number of resource-rich countries (Stevens, 2003; Stevens \& Dietsche, 2008; Ushie, 2013). Countries such as PNG, Nigeria, Ogaden in Ethiopia (Luft \& Korin, 2009; Klare, 2009; Müller-Kraenner, 2007) to name a few, have been caught in this vicious trap. It seems that governments in these countries tend to behave differently from non-resource rich countries. In fact, statistics have shown that non-resource rich countries tend to perform much better, for instance, Botswana (Barma et al., 2012).

This pattern of development outcomes has now compelled some IDAs to shift their development priorities to address the issue of energy governance related to energy security (Barma et al., 2012). IDAs such as WB, ADB have mounted a new Political Economy Approach (PEA) to assist governments to establish governing mechanisms such as building capacity and accountability measures to address the issue of energy poverty within the bigger framework of poverty reduction. Some of the recent examples include assisting developing countries to establish Sovereign Wealth Funds to ensure transparency and accountability in a sustainable way (World Bank, 2001).

\section{Part 5. Political and Economic Contributions to Governance of Energy Security}

\section{A. Developing countries}

There has been a rich literature on governance of natural resources but its relationship to energy security is limited. Several of these studies will be discussed here.

Sachs and Warner (2001) and others such as Auty (1993, 1995) provide an influential understanding of the relationship between the natural resource and economic growth. In fact, this study led to the coining of resource curse theory when they found a negative correlation between natural resource abundance with growth in a large cross-country study. This study gave rise to numerous studies focusing on negative associations between 
resource abundance and stability and the quality of a political system (Ross, 2001; Jensen and Wantchekon, 2004; Collier and Hoeffler, 2005; Bhattacharyya and Hodler, 2010).

In addition, there have been other similar studies that focus on the relationship between natural resource and institutions and economic growth. Baland (2000) and Torvik (2000) found that resource rents induce rent-seeking and corruption. Bhattacharyya and Hodler (2010) also established that resource rents often lead to corruption if the political institutions are weak. The most recent study by Tsani (2015) establishes that resource funds have a positive correlation with governance and institutions in terms of its distribution. She concludes that resource funds can be an insulation against resource curse as manifested in decaying governance and institutions. The resource curse theory has been vigorously challenged in recent years by a number of writers, including Manzano and Rigobon (2001) and Stijns (2006) who focus instead on debt and learning processes respectively.

However, few writers have been able to draw on the causal relationship between the natural resource and economic growth to link them with energy security. Building on from resource curse theory by Sachs and Warner $(1995,2001)$ and others, new studies have emerged to focus on how governance of energy resources contributes to energy security.

The latest of these studies is a quantitative study done by Sovacool et al (2016) on energy governance focusing on the relationship between the effectiveness of the Extractive Industry Transparency Initiative (EITI) and resource curse at the transnational level. This study is significant to the establishment of PNG EITI in terms of its relationship between energy governance and EITI. Sovacool and colleagues found that most EITI countries do not perform better during EITI compliance and that they do not outperform other countries. Based on these findings, they postulate that the weakness of the EITI is a result of a limited mandate, its voluntary nature, stakeholder resistance, and dependence on a strong civil society.

Another study by Sovacool and Andrews (2015) focuses on whether the Extractive Industry Transparency Initiative promotes transparency and accountability by government and corporate companies in the energy sector. By using qualitative case studies of Azerbaijan and Liberia the study found that it is difficult to establish governance improvements to EITI. It also established inconsistency in the virtue of EITI and that damage caused by mining and hydrocarbon development is socially and economically unavoidable. 
Sovacool and Dworkin (2015) focus on the positive side of governance of energy rents by paying attention to how resources and revenues from energy sources are prudently managed for future use and utilised in the local community for public good. Through a qualitative case study of Sa o Tome' e Príncipe (STP), the study found that, despite policy challenges, these policies generated government revenue, helped diversify the economy, lowered inflation and rates of poverty and minimised corruption and the exploitation associated with oil exploration and production.

The other contribution by Sovacool and Brown (2010) was a quantitative study done to establish the relationship between oil rents and the resource curse. Using a matrix of energy security to test this relationship across countries in South Asia in comparison to five largest countries of OPEC and BRICS, the study found that the resource curse is not occurring in these countries. Based on the findings, they conclude that resource curse theory perhaps is too simplistic and deterministic to explain why some countries are cursed and blessed. Their findings also support others who have disputed resource curse theory.

Moreover, Sturesson and Zobel (2015) focus on oil governance in Uganda as a petro-state. Through a qualitative study, they found that Uganda is highly vulnerable to the resource curse due to factors such as weak institutions and governance, social fragmentation, lack of political inclusiveness, and the opacity of Production Sharing Agreements (PSAs) signed by politicians and oil companies. Based on their findings the study concluded that a strong institution with capacity and capability is necessary.

The final study is a qualitative analysis conducted by Orogun (2010) on the Nigeria Delta in relation to resource control, revenue allocation, and petroleum politics. This study has relevance because it examines the complex interactions in the political economy of petropolitics involving MNCs, the state and the militia insurgents and specifies the root causes of conflicts, violence, and poverty that are associated with the 'paradox of plenty', 'resource curse' and 'shadow state syndrome' in most petrostates ${ }^{6}$.

In the context of Melanesia, researchers (Allen, 2013, 2017, 2018; Banks 2003, 2005, 2008; Ballard \& Banks, 2003; Togolo, 2006) attempted to evaluate the impact of resource governance and conflict. Their focus has been on the governance and management of minerals and petroleum that led to tension, dispute, violence and civil war. Several studies

\footnotetext{
${ }^{6}$ See also Le Billion, 2001; Ross, 2004; Watts, 20004a, 20004b, 2000c on similar cases.
} 
have revealed similar cases in PNG (Auty, 2002; Banks, 2008; Haley \& May, 2007; Hill \& Fletcher, 2018; Filer, 1997; Lasslett, 2014; Regan, 1998, 2014; Weiner \& Glaskin, 2007; Main \& Fletcher, 2018; Minnegal, Main \& Dwyer, 2018; Main, 2018; Koim \& Howes, 2016).

However, much of the research up to now has been quantitative in nature, focusing on the causal relationship between the natural resources and economic growth associated with resource curse theory. These findings are inconclusive (Konte, 2013). This suggests that while few of the resource-rich countries perform better than the others, they are highly vulnerable to resource volatility and that institutions matter in resource governance, a viewpoint that needs further exploration.

Having discussed some of the contributions to the governance of energy security, I will now move on to discuss contributions from PNG.

\section{B. Political and Economic Contributions from PNG}

This part discusses studies of the relationship between the natural resources and economic growth and energy security in PNG.

From the literature survey, three empirical and two theoretical studies from the political and economic perspective were identified. An empirical study by Imbun (2006) focuses on perceptions of Multinational Corporations (MNCs) on mining and petroleum regulations through a quantitative approach. Imbun found that MNCs have moderate satisfaction of the existing policy regimes regulating the industry and recommended that the government should attend to revenue generation prior to managing issues of management of revenue or distribution of proceeds from mining and petroleum projects or other related projects.

Another empirical study focused on the theory of Dutch Disease in PNG from a quantitative economic perspective (Avalos et al., 2015). The study found that PNG as a resource-rich country shows signs of natural resource curse disease, in particular, the Dutch Disease. Based on the findings the study concludes that governance is a pressing challenge and makes suggestions for reform in revenue management and spending.

The other two studies are Kuwimb's Masters and PhD theses $(1997,2010)$. These are qualitative and theoretical in nature. The former is an examination of the legal framework 
of petroleum in PNG which tested the hypothesis that the existing laws are weak and exploitative from a legal perspective. Based on his analysis Kuwimb concluded that PNG has a good legal framework that facilitates substantial benefits from resource exploitation, but there seems to be gross mismanagement of these benefits. Kuwimb's later work takes a political economy perspective to focus on resource curse theory. The study tested the hypothesis of the resource curse theory by examining the legislative arrangements in PNG drawing on from international literature. He concluded that for natural resource-rich countries such as PNG to avoid the curse of natural resource, they should follow developed countries by reforming their laws.

A further qualitative study is an unpublished Master's thesis by the author (Hualupmomi, 2012). This thesis focuses on the geopolitics of resources, in particular mining and petroleum in PNG, from an international political economy perspective. The study found that geopolitical interactions between or among great powers in PNG also affect domestic development through operation of MNCs. The study concluded that PNG should play a neutral game among great powers to maximise national interest (Hualupmomi, 2012).

Anoser (2013), in his Master's thesis, focused on resource benefit sharing arrangements (BSA). The study found that there have been few BSA in the past which have not captured the equal distribution of benefits to resource owners. The study concludes that BSA should be strengthened through the Development Forums and that process, legal requirements and other characteristics of BSA must be properly organized by the government to promote equal benefit sharing for development.

George (2013), in his Master's thesis focused on how MNCs were to determine Corporate Social Responsibility (CSR) practices in one Petroleum Company (Oil Search Ltd) in PNG. He examined the ways in which the concept of CSR is broadly understood at the governmental or corporate levels. The study found that there was lack of planning and policy at institutional levels which affected MNCs' CSR and government's constitutional obligations of service delivery to affected landowner communities.

Two recent contributions are literature reviews done by Ila'ava (2014a, 2014b) on PNG's international security and national security. The reviews explored existing literature on international security and national security. The former focused primarily on geopolitics in PNG, whilst the latter discussed internal security issues and challenges. Despite the relevance of the reviews on PNG's security, energy security was not clearly captured. 
The studies presented above are largely based on resource governance, in particular, petroleum. Looking across these studies, it is apparent that the study of resource governance relating to energy security in PNG and internationally is limited with no explicit linkage made between energy governance and energy security.

\section{Part 6. Governance and Accountability Reports}

A good number of reports ${ }^{7}$ related to $\mathrm{LNG}$ governance, both at the national and international levels, have provided noble suggestions and recommendations for policy makers to adopt best operational and adaptive quality governance approaches in improving and strengthening resource governance in order to enhance energy security.

At the national level, several reports and policy documents raise the issue of energy governance related to energy security and proposed areas of improvement (see, for example, PNGEITI, 2013, 2014, 2015, and 2016). First, almost all reports and studies have shown that compliance with the existing governance systems and process is lacking and strongly recommended that the government, IOGCs and NOGC should improve in this area. For example, the PNGEITI strongly recommended that all stakeholders in the petroleum energy industry must effectively report on their financial statements. That is, the government, producing institutions, and revenue-generating institutions should be transparent in producing timely and adequate revenue and expenditure reports.

Second, some reports foregrounded the deficiencies within the taxation system and suggested for the government to improve the taxation system in the country as it seems to be outdated in respect of the energy governance arrangements. The NRI report edited by Odhuno (2014) and PNG Tax Review Committee (2015a, 2015b) indicated that PNG has been losing millions of Kina as a result of the existing tax regime and highly recommended that the government strengthen the taxation system, processes and structure. This included building and modernizing the tax administration, administrative capacity, and strengthening enforcement and compliance of taxation regime.

Third, NRI reports (Osborne, 2015; Voigt-Graf, 2015) identified some weaknesses in the SWF and suggested improvements, in particular on the management of the fund and the need to operationalise the OLSWF by establishing the administrative structure.

\footnotetext{
${ }^{7}$ Refer to Appendix 9 for a list of reports.
} 
Fourth, the DFW (2013) and PNGNSP (2013), in discussing the vulnerability of the existing security system in relation to energy security, suggested the need for the government to strengthen the security institutions, systems and processes. The policies also suggested modernising the military in the $21^{\text {st }}$ century to protect national strategic assets such as oil and gas in the country.

Fifth, an ANZ report (2013) suggested that the government should diversify the economy by investing in agriculture and infrastructure. That is, windfall of revenues should be strategically invested in high return areas to sustain the economy and peoples' social wellbeing. Given the LNG revenue generated for PNG, the report also suggested the government should enhance good governance of these assets.

At the international level, numerous reports also suggested that governments around the world should adequately provide protection from disruptions of vital energy systems. For instance, Cherp et al (2012) suggested that in the face of disruptions of energy systems from both short-term shocks, such as natural events, technical failures, malfunctioning markets, or deliberate sabotage, permanent threats, such as resource scarcity, aging of infrastructure, and unsustainable demand growth there is a need for the governments around the world to develop an adaptive system to respond to these surprises. The reason being that such disruptions may affect broader security issues ranging from the viability of national economies and stability of political systems to the danger of armed conflicts.

Seventh, some international energy policies also suggested the government should establish a strategic stockpiling of oil and gas for times of emergency (Kobayash, 2015). Since PNG does not have a national stockpiling system, it is important that the government immediately establish one to cater for disruptions from geopolitics, price fluctuation, natural disasters and domestic needs such as the demand for electricity. This would also support Domestic Market Obligation which is outdated in PNG. Others such as Yergin (2006) suggested that, given the complex changing global political and economic environment, it is necessary for governments to develop an adaptive security system that is able to read surprises and respond accordingly by way of diversifying energy sources and pursue cooperation and collaboration within the existing bilateral and multilateral framework. 
Eighth, a notable global governance institution, The NRGI (2017), has provided six recommendations for resource-rich countries to promote and improve resource transparency and accountability. These include:

- Focus on implementation by strengthening the implementation of laws and regulations in extractives particularly in lagging areas.

- Continue open government by publishing details of what you pay; the true beneficial owners of companies; the commercial interests of officials and their associates; the deals governments make and the detailed project-level payments companies make to governments.

- Bolster state-owned enterprise governance given their weaknesses relating to the regulation and disclosure of oil sales. These include strengthening the corporate governance of SoEs by establishing independent governing boards; making appointments according to well-defined, meritocratic processes and emphasizing technical expertise rather than political patronage.

- Protect civic space and combat corruption by recognising the citizens' ability to participate in selecting and monitoring their government; their freedom of expression and their freedom of association where governance of extractive industry is flawed.

- Strengthen global norms and institutions where governments of countries home to extractive companies, international institutions and nongovernmental organisations should further strengthen the global framework for natural resource governance, including influencing how multinational companies behave. For instance, the work of EITI should be recognised in PNG.

- Use data to drive reforms to help inform better policy decisions and improve governance and corruption control. This may involve measuring and monitoring the quality of governance and effectiveness of resource and revenue management throughout the 'value chain'; design measures to improve institutions, policies, and practices based on such evidence-based assessments and fund the development of institutional systems providing regular and timely gathering, analysis and dissemination of key data in resource-rich countries. Governments should also ensure that public information about the resource sector is released in line with the Open Data Charter standards. 
Last but not least, there is a need to strengthen the Parliamentary Committee System in PNG. While there appear to be many such committees based on the Westminster system,

only few remain active yet they are not that effective. Two of the committees that are important to energy governance and security are the Public Accounts Committee and Constitutional Law, Acts and the Subordinates Committee. Some researchers (e.g. Werner Cohil, 2017) argue that the effectiveness of these two committees in terms of their recommendations is often overshadowed by the political actors. One such example is that, over the years, the Constitutional Law, Acts and Subordinates Committee has been seen as a 'rubber stamp' in ensuring 'checks and balances'. The committee, on many occasions, was not able to withstand draconian laws, or worse better, bulldozed laws. Similarly, Hassall (2011) sees the political culture of politicising the committee outside of the effectiveness of the parliamentary system in ways that contradict the formal parliamentary governance in PNG. Given these weaknesses, the committees need to be strengthened.

This review emphasises the need for a theoretical framework for examining the state of energy governance and energy security, which is discussed in the next part.

\section{Part 7. Theory and Concept}

\section{A. Theory}

This study adopts a political economy theoretical framework that builds on different but complementary insights from political economy (power-based theory [PBT] and rentierstate $[\mathrm{RS}]$ and rent-seeking theory $[\mathrm{RST}])$. PBT contends that power is the central unit of analysis in order to understand how politics affects the governing of petroleum energy resources to maintain the political actors' grip on power. It considers institution, ideas and cultural aspects as important elements of power which political actors tend to use as a political means to gain influence otherwise unavailable to them to enable their political survival (Hudson, 2014; World Bank, 2008). RS centrally argues that decision-makers in natural resource-rich countries create and maintain growth-restricting policies. RST posits that oil economies induce a high-level of rent-seeking and corruption where there is lack of strong legal-political institutions dominated by multiple powerful interest groups. These theories elaborated further in this section, provide a useful basis from which to examine how governance of energy contributes to energy security in resource-rich countries. 
According to Di John (2011), there are several important propositions within the RS framework:
"existence of a higher level of mineral rents increases
rent-seeking and corruption relative to economies with lower mineral abundance; increases in rent-seeking and corruption generate lower growth; oil rents provide a sufficient fiscal base for the state and, thus, reduce the necessity for the state to tax citizens. This, in turn, reduces political bargaining between state and interest groups, which makes governance more arbitrary, paternalistic, and even predatory; and absence of incentives to tax internally weakens the administrative reach of the state, which results in lower levels of state authority, capacity, and legitimacy to intervene in the economy" (Di John, 2011).

In other words, Di John (2011) posits that resource curse is not caused by economic conditions but by specific historical arrangements of institutions; this often generates negative development outcomes.

Tornell and Lane (1999) assert that in such an economy, powerful groups dynamically interact through the fiscal process that permits access to capital stock. Di John (2011) neatly sums up these theories by positing that there is a cost to the economy when allocation of resources is channelled through state-leaders, who have discretionary authority, rather than through bargains between private economic agents. Since revenue generation is the central function of governments in oil economies, the level of allocation of resources and regulation of the economy tends to be higher than in most non-oil economies. Therefore, the tendency for high-level rent-seeking and corruption is increased compared to nonmineral economies (Di John, 2011).

Overall, a political economy theory, drawing on Power-based Theory, Rentier State, and Rent Seeking Theory, will significantly inform and advance our understanding of governance of energy security in the PNG context and will likely also be applicable in a broader context. 


\section{B. Concept of Ownership}

Ownership and property rights are two associated concepts. Ownership refers to the 'bundle of property rights' (Howell, et al., 2018). Property rights are the socially acceptable uses to which the holder of such rights can put the scarce resources to which these rights refer (Demsetz, 2009) ${ }^{8}$. That is to occupy and use the property, to enjoy the income generated from the legally permitted uses of the property, to exclude others from using the property, and to transfer control of some or all of the property rights to other owners and for whatever consideration is available. According to Quigley (et al., 2009), "in practice, the last of these rights clearly defined ownership because ownership could be retained even where use and exclusion rights were transferred through a lease or impaired by government action".

What it precisely means is that a proprietor who owns a certain property has a 'bundle of rights', therefore, has the ability to exercise that right in its best interest. That same principle also applies to the ownership of land and minerals and petroleum resources within it by the proprietor (landowner and state).

A generally held view is that the ability to exercise control over a bundle of rights rests with the state (Howell, et al., 2018) through governing institutions such as SoEs. This is where shareholders-owners have contracted away almost all of their rights to make decisions about the use of the relevant assets to the board and management of the firm (Howell, et al., 2018).

In PNG, the concept of ownership applies to both the customary landowners and state. The customary landowners own about 98 percent of the land whilst the government owns about 3 percent of the land (Encylopedia, 2015). That means they (customary landowners and state) have a 'bundle of rights' in maximising optimal output and outcome from the land and minerals and petroleum resources. However, for the purpose of minerals and petroleum development the state negotiates with the customary landowners to access land through lease. In many ways, the concept of ownership, especially on the question of who owns the resources, whether it is customary landowners or the state, is a complex and controversial legal issue in PNG (Ongwmuhana \& Regan, 1991). Through this system of ownership a benefits framework is developed by the state as is discussed throughout the thesis.

\footnotetext{
${ }^{8}$ See also Demsetz, 1967, 2002
} 


\section{Part 8. Summary - Research gap in this study}

Increasing interest in the governance of energy resources in resource-rich developing countries has heightened the need for better understanding of how energy governance contributes to energy security. The studies reviewed above generally show a relationship between natural resource governance, economic growth, and energy security. The actual dynamics involving causality of these relationships remains obscure. That is, to date, scholars have been focusing on one aspect of energy security without considering its underlying interdependencies and complexity from a holistic view. This suggests that governance of energy security in resource-rich countries including PNG is understudied and under-theorised despite increasing interest.

It should be noted, for instance, that studies by Sovacool $(2014 ; 2015 ; 2016)$ clearly show that studying energy governance as a subject of insecurity to society is as important as other aspects of energy security. Sovacool's conclusion appears to hold for PNG as well, where the focus to date has been highly concentrated on governance of resources, particularly mining and petroleum, without consideration of how this links to energy security. For instance, a study by Imbun (2006) on MNCs' perception of government's regulatory arrangements and how these might affect developments in the mining sector clearly demonstrates this literature gap. Findings of studies conducted in PNG do not clearly indicate how energy as a subject of insecurity affects development in terms of economic growth and quality of institutions as indicated by Kuwimb $(2009 ; 2010)$. These studies have addressed only the question of how resources are governed in relation to the regulatory regime and development outcomes. They have not explicitly examined the linkages to national development and national security. This study aims to fill this gap as identified in the literature so far. It will do so by exploring governance of energy security in PNG.

Having reviewed the existing literature and identified the knowledge gap around our understanding of the relationship between energy governance, energy security and the governance of energy security, the final part of this chapter concludes with a framework for examining the quality of energy governance. 


\section{Part 9. A Quality Energy Governance Framework (QEGF)}

Economic development and political stability in resource-rich developing countries depend on good governance of natural resources. Without good governance, progress in development is impaired and the security of the State is at stake. The management of LNG energy in PNG is a billion-dollar industry that requires effective governance systems and structures to better manage massive rents extracted and exploited from the petroleum energy sector for energy security outcomes. The performance, adaptability, and stability of PNG's LNG energy resources depend on the quality of governance. An effective and efficient governance system will ensure regime adaptability and stability. And, in turn, the qualities of an effective governance system and structure can enhance energy security and development outcomes.

The likelihood of achieving development outcomes can be assessed using a set of critical governance qualities. The extent to which these qualities are attended to ${ }^{9}$ also determines the level of regime stability and securitisation ${ }^{10}$ of energy (Buzan, 1998). Whilst policy regimes can change in tandem with a change in ruling government, the stability of performance of the institutions in the sector is determined by the characteristics of governance within which they are politically and legally structured.

Based on the literature review and knowledge gap identified, a modified version of the Resource Governance Index used by the Natural Resource Governance Institute (NRGI, 2017 ) is developed as the guiding quality governance framework used in this thesis. This framework is contextually appropriate for my research question because it uses globally accepted principles of energy governance reflected on indexes to understand governance of natural resources at multiple or different levels of complex decision making. For these reasons, it is applied to an understanding of the political governance of energy and its contribution to energy security in PNG.

The intention is to use this framework in analysing the LNG energy governance system and structure in terms of the institutions, rules, and practices that determine how the government makes decisions, engages with different affected actors and influences outcomes within the operating environment in the energy sector. This will help in positioning the results in a

\footnotetext{
${ }^{9}$ Measurement here refers to qualitative assessment given the nature of the study.

${ }^{10}$ Securitisation of energy refers to the level of regime stability that generates energy insecurity or enhances energy security.
} 
broader analytical framework, drawing connections and relating them to the theory (Wolcott, 1994:29-36).

The QEGF has four components: value realisation; revenue management; enabling environment; and security ${ }^{11}$. Value realisation covers the governance of allocating extraction rights, exploration, production, environmental protection, revenue collection and state-owned enterprises. Revenue management covers national budgeting, subnational resource revenue sharing and sovereign wealth funds. The third component assesses the enabling environment for energy governance provided by the State. The last component assesses whether the other three components generate or enhance energy security (NRGI, 2017). These dimensions of quality governance though are uniquely different, and yet overlap each other in many ways. For instance, should a financial report of an IOGC be unavailable publicly for access, this may raise the question of transparency and accountability. And transparency constitutes certain characteristics such as distortion of information to avoid tax, which per se, could destabilise the regulatory regime, thereby generating security concern for the State.

While the framework resembles important quality dimensions in a more general sense, for this study, particularly chapters five, six and seven, the focus is on critical qualities of LNG energy governance. Figure 1 shows the framework and its constituents.

\footnotetext{
${ }^{11}$ I have added security into the Resource Governance Framework purposely to establish the link between energy governance and security based on the literature gap.
} 
This content is unavailable.

Please consult the print version for acess.

A modified version of Resource Governance Index from the NRGI

It is equally important to note that quality characteristics of the framework are further filtered by the regime type as strong or weak for the purpose of discussion in the thesis. Energy regime constitutes laws and regulatory and institutional arrangements governing energy whilst energy system constitutes system and structure in terms of the institutions, rules, and practices. Energy regimes that are strong exhibit transparent and accountable processes, systems and structures that facilitate good governance which in turn generate and enhance security and improve development. On the hand, energy regimes that are weak exhibit the opposite. This distinction will be used throughout the thesis.

To conclude, there is a knowledge gap in our understanding of the linkages between energy governance and the governance of energy security for the purposes of development 
outcomes. This conclusion was reached by first reviewing the definitions of these terms and the emergence of energy security as a particular school of thought related to national security and development outcomes. It then presented the political and economic contributions to thinking about the political governance of energy security in OECD countries, resource-rich developing countries, and PNG. These include an understanding of the concept of ownership. These contributions forged the theoretical framework used in this research. Finally, a quality energy governance framework, modified from NRGI in the light of the literature review is adopted as an analytical framework to be used in the analysis phase of the thesis. This now sets the stage for a study designed to better understand the linkages between energy governance and energy security in the PNG context. 


\section{CHAPTER 3: BACKGROUND}

Chapter three provides the background of the study, in particular an overview of PNG, its geography, history, politics and economy, and petroleum and energy sector and its institutions, policy and legislation. The aim is to provide the background in which energy is governed.

\section{Part 1. Political and Economic System of Papua New Guinea}

This section sets the research context by focusing on PNG's political and economic system and how energy, in particular, petroleum is located in the governance problem of the stateeconomic-society relations. It also provides an insight into the institutions, policies, and legislation relevant to the energy and petroleum sector.

\section{A. Geography, History and Economy}

PNG is located north of Australia in the Western Pacific with an estimated population of about 8 million people, multi-ethnic and speaking over 800 different languages. It is a Melanesian island country sharing a land border with Indonesia (Gibbs, 2006). PNG has a mixed economy (formal market and informal subsistence). Historically, portions of the island were colonised by Germany (New Guinea) and Britain (Papua). After World War Two the northern and southern regions were combined as a Trust Territory of the UN under Australian administration, until self-government in 1973 and independence in 1975 (ADFAT, 2006).

About 80 percent of the economy is subsistence-based or sub-agrarian farming and small scale businesses. The economy is rich in such natural resources as oil and gas, gold and copper, forestry, fisheries, cocoa, and copra. It is also a capital-intensive economy due to the heavy manifestation of mining and petroleum activities (GoPNG, 2010).

\section{Economic Performance}

PNG's economy has performed well from early 2000 to 2011. It enjoyed a decade-long period of stable economic growth due to political stability, prudent fiscal management, and robust macroeconomic policies that formed the backdrop of LNG construction. After a 
slow or negative growth in the 1990s, the GDP began to pick up in mid-2000. The positive growth during this period sustained the economy. PNG was recorded as one of the fastest growing economies in the Asia-Pacific region. The LNG project was expected at that time to further drive the growth from 14 percent to about 21 percent by early 2020 (Levantis \& Sanida, 2015; Osborne, et al, 2017).

However, in 2011, the economy experienced a decline in growth. This decline was attributed to low commodity prices and governance issues (Levantis \& Sanida, 2015; Osborne, et al, 2017; World Bank, 2017). According to the Trading Economics (2018) based on Bank of PNG data, the GDP trended downwards from 11 percent in 2011 to about 2.5 percent in 2017 despite LNG export since 2014. The LNG export was expected to spur the economy by 2014 , but instead, it declined. The debt level has increased dramatically due to overspending and borrowing. This has affected the national budget in financing and sustaining socio-economic services. The exchange rate dropped sharply and weakened foreign reserves to sustain the private sector (Flanagan, 2015).

During this period (2002-2017), the World Bank (2017) reported that despite some progress in improving development indicators such as health outcomes, indicators had remained low compared to other countries in the same development category.

\section{Government System}

PNG adopted a Westminster system at independence in 1975 (Kavanamur, 2003). As a constitutional democracy, it has three arms of government: Executive, Legislative, and Judiciary. Its parliament comprises 111 members, elected nationally every five years, representing 22 provinces and 89 districts (National Parliament of Papua New Guinea, 2016). The constitution defines and demarcates the jurisdictional functionalities. The Executive arm of the government comprises executive government made of ministers appointed by the leader of the party or coalition party with the Prime Minister as the Chief Minister. The executive government is the National Executive Council (NEC) which makes executive decisions such as the appointments of the head of government agencies and businesses and approves policies and proposes legislation. The bureaucracy sits under the executive branch to provide advice to the government and implement government decisions. The Legislature makes and amends laws. The Judiciary interprets the law in practice and enforces it. 
The structures and system of government have undergone major reforms since the mid1990s (National Parliament of Papua New Guinea, 2016). There are currently three levels of government: national, provincial and district. The central functions include Defence, Foreign Affairs and Trade, Treasury and Finance, National Planning and Monitoring, Personal Management, and Provincial and Local Level Government Affairs (National Parliament of Papua New Guinea, 2016). A more recent concept introduced at the district level is the District Development Authority, which performs functions on behalf of the provincial government to deliver services at the district level (Colin, 2014).

The governing of society also involves the contribution of civil society in decision-making regarding important policies and legislation through consultation (Gapromas Problem Management Services, 2014). NGOs and Faith-based Organisations play a complementary role in development. For instance, anti-corruption advocacy programs are often performed by non-governmental organisations such as the Transparency International PNG Chapter. In this respect, the state-society relationship is one of the key tenets of parliamentary democracy as prescribed in the constitution.

PNG is also a member of the Commonwealth in which the Head of State is the Governor General representing the Queen. The Governor General performs ceremonial duties apart from endorsing political and administrative elections and appointments and legislation upon advice from the government (Gapromas Problem Management Services, 2014)

\section{The Political Party System}

PNG has a multiparty system that is characterised as fluid in that no single party dominates but each collaborates or manoeuvres to form the government (Hambly \& Morgan, 2008; May, 2008). The political culture of PNG electoral politics is such that during the elections the number of parties increases. Many have similar policies and eventually die out after elections (Okole, 2005). However, independent candidates in electoral politics exert a minor influence and very few independents make it to the parliament.

Prior to the Organic Law on Integrity of Political Parties and Candidates (OILPAC) in 2003, a law was passed in Parliament to prevent political instability, where changes of party allegiance among elected representatives could precipitate votes of no confidence and ministerial reshuffles. Moreover, the multi-party system has also influenced survivability 
of the prime ministers. There have been 14 prime ministers since 1975 who were either elected via national elections or assumed power following a vote of no-confidence between elections. Of all the Prime Ministers, only Grand Chief ${ }^{12}$, Somare served his full 5-year term as the Prime Minister. Even he was removed as the Prime Minister on occasions during his term through a vote of no-confidence. However, in 2011 he was removed unconstitutionally by the O’Neill government through a political impasse ${ }^{13}$ (Wolfers, 2012). Similarly, between 2003-2017 there have been frequent ministerial changes in the Petroleum and Energy Ministry. The significance of this is that various governments have altered energy policy to suit their interests (see Figure 2 for details).

Figure 2. Changes in Petroleum and Energy Ministers under Somare government and O’Neill government

\begin{tabular}{|c|c|c|c|c|c|}
\hline Year & $\begin{array}{l}\text { Ruling } \\
\text { government }\end{array}$ & $\begin{array}{l}\text { Prime } \\
\text { Minister }\end{array}$ & $\begin{array}{l}\text { Minister for } \\
\text { Petroleum } \\
\text { and Energy }\end{array}$ & & $\begin{array}{l}\text { Frequency of } \\
\text { Ministerial } \\
\text { Changes }\end{array}$ \\
\hline $\begin{array}{l}2002- \\
2011\end{array}$ & $\begin{array}{l}\text { National } \\
\text { Alliance } \\
\text { (NA) }\end{array}$ & $\begin{array}{l}\text { Grand } \\
\text { Chief, Sir } \\
\text { Michael } \\
\text { Somare }\end{array}$ & $\begin{array}{l}\text { Sir Moi Avei } \\
\text { William } \\
\text { Duma }\end{array}$ & $\begin{array}{l}\text { NA } \\
\text { United } \\
\text { Resource } \\
\text { Party } \\
\text { (URP) }\end{array}$ & 0 \\
\hline $\begin{array}{l}2011- \\
2017\end{array}$ & $\begin{array}{l}\text { Peoples } \\
\text { National } \\
\text { Congress Party } \\
\text { (PNC) }\end{array}$ & $\begin{array}{l}\text { Peter } \\
\text { O’Neill }\end{array}$ & $\begin{array}{l}\text { William } \\
\text { Duma } \\
\text { Nixon Duban }\end{array}$ & $\begin{array}{l}\text { People's } \\
\text { Progress } \\
\text { Party (PPP) } \\
\text { URP } \\
\text { PANGU }\end{array}$ & 5 \\
\hline
\end{tabular}

\footnotetext{
${ }^{12}$ Grand Chief is the highest order of political recognition or honours accorded to politicians and professionals who have an outstanding or distinguished record of service for Papua New Guinea.

${ }^{13}$ PNG experienced a constitutional crisis where the Court ruled that the removal of Grand Chief Somare was unconstitutional, which O'Neill refused to accept through a legal battle until the National General Elections. That was the time in which the LNG revenue was forthcoming.

${ }^{14}$ Hon. Sam Basil, the leader of PANGU Party, joined the Government from the Opposition in October 2017. As a result of this move, he was rewarded with an additional minister of energy. It is interesting to note here that the Ministry of Petroleum and Energy still remains but energy was also a part of Hon. Sam Basil's new
} 
On the other hand, such a party system might be expected to enhance democracy (Allison et al, 2013; May, 2008). PNG's multi-party system creates a political environment for active and inclusive social interaction between and among parties and politicians to truly exercise freedom of choice in promoting and protecting democracy (Migdal, 1988). When one is allowed to exercise freedom of choice and movement through multiple channels of politicking, weak government is pervasively held accountable and transparent to the populace. The vote of no-confidence has positively contributed to change of government to ensure checks and balances. An example of this is the change from the Skate government to the Mekere government over governance and corruption issues which precipitated the economic crisis in the late 1990s.

Despite the amendment of electoral law by the Chan government in 1992 to extend the grace period between votes of no-confidence to 18 months, there was little improvement in political stability. The Organic law on the Integrity of Political Parties and Candidates (OLIPAC), introduced by the Mekere government in 2001, brought more political and economic stability because it regulated the political parties, candidates and politicians behaviour during and after elections. This law also provided a stable political environment for government to create a more conducive environment for the economy to grow. This was evidenced by the Somare government being the first government to serve its full term since the system was introduced at independence. The economy was also stabilised as a result. However, OLIPAC was challenged in the court of law and declared unconstitutional in 2010 .

\section{E. Policy System}

The policy environment in PNG is generally unstable. Linda and others noted that, since 1975, the policy environment is characterised by frequent policy change based on the interest of the ruling party and government (Kavanamur \& Turner, 2009; Linda, 2010). The multi-party system of the country tends to encourage ambitious policies and development

function. One explanation for this decision could be that the O'Neill Government made this decision in the interest of maintaining the ruling government to avoid political instability. The table clearly shows the frequent ministerial changes in the O'Neill government than the Somare government; there was stability in the Somare government. Perhaps the longest serving Minister for Petroleum and Energy was Hon. William Duma who served under two political governments since 2007. 
plans, which, in large part, rarely last long - policies often, do not last long without completing their life cycle. It is often the case that when a new government is formed, new policies with same philosophy are introduced with a strategic intent to attract public confidence and build political capital.

Policies and development plans in PNG are linked to PNG's founding fathers' philosophies and its development pathway is anchored on The National Goals and Directive Principles (NGDP) embedded in the Papua New Guinea National Constitution ${ }^{15}$ (Ambang, 2012). Since 1975, PNG has crafted nine consecutive development plans without full implementation or fairly mixed results. The first development plans and subsequent policies were in direct response to the political transition and development challenges (DNPM, 2010). Policy history has revealed that almost all of them did not fully achieve their strategic objectives, for instance, public sector reforms (Kavanamur \& Turner, 2009; Linda, 2010). Given this policy trend, in late 2000, the National Alliance (NA) government decided to create a stable policy environment as an ambitious forward-looking strategy to drive PNG's modernisation agenda - Vision 2050 was the outcome of this policy shift (GoPNG, 2010).

Vision 2050 is a home-grown, long-range, strategic policy framework with a range of broad goals as directive statements. In essence, it provided an ambitious philosophy on which other subsequent policies and plans are made or would succinctly follow (DNPM, 2010). The Vision 2050 pillar on Environment Sustainability and Climate Change particularly 'strategy 1.17.9.3 Climate Establish a Sustainable Development Policy in all sectors, especially forestry, agriculture, mining, energy and oceans by $2015^{\prime}$ calls for sustainable energy (GoPNG, 2010:10).

The Development Strategic Plan 2030 (DSP) translates and operationalises Vision 2050 goals into sectoral strategies to be implemented by each sector. The sectoral plans are aligned to the Medium Development Plan 2011-2015 (MDTP) (DNPM, 2010). All micro policies are, therefore, sectorally aligned to achieve Vision 2050 targets. In terms of petroleum and energy, the DSP envisioned to 'Build a world leading petroleum industry

\footnotetext{
15 The NGDPs are found in the Preamble of the Constitution of Papua New Guinea:

1. Integral Human Development

2. Equality and Participation

3. National Sovereignty and Self-reliance

4. Natural resources and Environment

5. Papua New Guinean Ways
} 
that maximises benefits to PNG and landowners, minimises impacts on the environment and maximise social welfare, and provides PNG with energy security' (DNPM, 2010:96). The MDTP states that 'achieving the goal for petroleum requires a strength of the state institutions for policy making, administration, and enforcement of regulations within the first MTDP. An important strategy is to have an efficient and effective delivery mechanism' (DNPM, 2010: 95-96).

Unfortunately, the DSP did not last long. It was replaced by the National Strategy for Responsible Sustainable Development for PNG (STaRS) in 2015 (DNPM, 2015). The STaRS focus is more on green economy, hence this statement "Wealth creation: setting the direction for the economy to move from an economy heavily dependent on non-renewable natural resources to one which has a broader base with dynamically developed industries in both secondary and tertiary sectors and with well-connected and vibrant markets". However, what is relevant for this study is that energy and petroleum sector policies and plans are, or will be, aligned to the Vision 2050. For instance, the PNG National Energy Policy 2016-2020 (PNGNEP) is framed on the premise of Vision 2050.

\section{F. Political Economy of Governance and Development in PNG}

In a political economy of natural resources and development, politics has been thought of as one of the key factors in influencing the pattern of development outcomes. The interplay between politics and natural assets explains issues such as resource curse and Dutch Disease (Collier, 2006; Collier \& Hoeffler, 2005). How the structure of governance is designed to facilitate resource management and development within a political system is critical in ensuring equal distribution of power and wealth in the society (Kahn, 2000a, 2000b, 2001, 2004, 2006, 2007, 2010). In essence, political values, institutions, and parties play a critical role in limiting the unacceptable behaviour of political elites in influencing policies at every levels of decision making (Jain, 2001; North, 1990). However, in practice, governance in advanced countries, and especially developing countries, continues to face significant challenges relating to corruption.

Acemoglu and Robinson (2012) argue that power and wealth has a strong link to politics and corruption. The social interaction between political institutions and wealth owners determines certain policy and development outcomes. 
Johnston (2005) contends that ownership of wealth affects governance of resources where wealth-owners collaborate with holders of political powers to exploit benefits outside of the established rules. This is where unequal power distribution leads eventually to unequal distribution of income and wealth and poor implementation of government policies.

Acemoglu and Robinson (2005) furthermore argue that political actors acting as agent for and on behalf of the Principal, in this case the citizens, in many ways exploit wealth. Given the asymmetry of information relating to how business is conducted it is quite difficult to ensure transparent contractual arrangements between business agents and state agents negotiating for resource benefits. This is where allocation of rents and patronage play a role in influencing fair distribution of wealth due to nature of differing political settlements across countries. In so doing, it weakens the institutions to function effectively (Kahn, 2010).

Moving on now to consider PNG's practical experiences.

\section{Rent-seeking, Patron-client Relations, and Corruption in PNG}

Governance has been a major problem in PNG. Of particular concern is corruption that is widely seen not only by Papua New Guineans but scholars and international development partners (Barma, 2014; May, 2004) as an immoral disease that continues to undermine the rule of law, the legitimacy of the governing system and the fabric of society. Some commentators often tag PNG as a 'failed state' in Melanesia as a consequence of poor governance and high levels of corruption (Standish, 2007).

Governance issues in particular, corruption in PNG is well characterised by rent-seeking and patron-client relations. It is systematically institutionalised where it penetrates all levels of the governing system (Allen \& Hasnain, 2012, Wood, 2018).

Rent-seeking in PNG occurs mostly between politicians and corporate or business entities (Barma, 2014). In many ways, politicians especially, those with ministerial portfolios, often establish symbiotic relationships with corporate and business entities to maximise their political and commercial interests. The politicians on one hand receive rents from the corporate and business entities to facilitate their elections and stay in power. On the other hand, the corporate and business entities in return receive political support for their commercial interest. A notable example is the awarding of contracts by government 
agencies directed by politicians to commercial and business entities in different sectors of the government system. The two most politicalised sectors in the economy are natural resources and development infrastructure (Barma, 2014; May 2004). The controversial relationship between politicians and the Rimbunan Hijau (RH) Group of companies is another classic example.

Similarly, patron-client relationship is another way in which corruption is facilitated in the governing system (Wood, 2018). This relationship is largely driven by the cultural orientation that shapes governing actors' behaviour and interest within the governing system (Morgan, 2005). The social interaction between political actors and bureaucrats, and to some extent the corporate and business entities, are institutionalised in a hierarchy of leadership in the Melanesian context where a political actor is seen as a 'big man' who can demand and command respect from his supporters and those below his ${ }^{16}$ jurisdiction. This political culture has been dominated and influenced the distribution of power and resources in an unequal way. In such cases, politicians often appoint their own bureaucrats (more appropriately, cronies in terms of friends and family members) ${ }^{17}$ to key positions in order to facilitate their political interest. The appointment of some heads of government agencies and SoEs as reported in the media illustrates this point clearly (Allan \& Hasnain, 2018). Moreover, constitutional funds such as the Provincial Development Grants and District Development Grants have been used by the Executive government as a political tool to suppress other politicians especially the Opposition politicians (Howes, 2017a, 2017b).

In general, governance, in particular corruption, is institutionalised and continues to affect development outcomes in PNG. The PNG National Security Policy (2013) clearly identifies governance and corruption as a national security issue. The key argument is that distribution of resource wealth has largely been exploited by the elites in power, which poses a credible threat for human development.

\footnotetext{
${ }^{16}$ PNG is both a patrilineal and matrilineal society but practically, a man tends to dominate the society in decision-making.

${ }^{17}$ In some cases, the politicians' nominees for a top post in the public service or SoEs are often unqualified
} 


\section{Part 2. Papua New Guinea Petroleum and Energy Context}

This section introduces PNG's energy and petroleum context by providing a sectoral overview of policy, legislation, institution and actors.

\section{A. Energy Sources}

The energy resources of interest in this research are non-renewable, liquid fuels and petroleum.

PNG is rich with abundant non-renewable and renewable energy resources. While smaller than the mining sector, the energy and petroleum sector in PNG contributes 14 percent of GDP to the economy. The energy sector depends on three main types of energy: Electricity, oil and gas (Aiau, et al; 2015). Oil and gas dominate the sector and is mostly used for revenue generation. The natural gas sector is huge and is equivalent to at least 2700 million barrels of oil (or even more). This will be depleted as more extraction continues (IRENA, 2013). There has been discussion with the IOGCs to supply electricity with LNG. The potential for hydro and coal and renewable energy such as geothermal, wind, solar, tidal, sea wave, and biofuel is currently under policy consideration but is outside the scope of this study (UNDP, 2015). The renewable resources are still underexploited due to organisational and technological reasons (Aiau, et al, 2015).

\section{B. Demand for and Supply of Energy}

World-wide energy demand and supply are unpredictable given the complexity of the changing economic and geopolitical environment, natural disasters, and innovation in technologies (PSI \& WEC, 2013). Energy demand has continued to grow, driven by nonOECD countries such as China and India. For instance, World Energy Monitors demonstrates how world energy leaders are constantly panicked by uncertain energy prices (PSI \& WEC, 2013).

The rapid growth of the PNG economy in the last decade has propelled a significant rise in demand for domestic energy. The demand for affordable and reliable sources of energy is a major challenge in PNG's drive towards industrialisation and modernisation. Despite significant domestic sources of energy, in 2014, 54 percent of the energy consumed by the 
country was imported making the governance of energy supply a significant issue for PNG. Of this energy use, the major component, petroleum, has been mainly used in the transport, power generation, and commercial and industrial sectors including households (APERC, 2012).

\section{Exploration and Production}

Oil and gas were originally sighted in 1884 during the 'Gold Rush' along the creeks, streams, and rivers of British Papua. By 1911, oil exploration had begun at lower Vailala River, Ihu District of Gulf Province of Papua (former British New Guinea). The year 1911 was also officially recorded as the 'oil and gas age' in PNG by Mr. J.E Carne (assistant Government Geologist) of New South Wales and Mr. E.R Stanley (the first Commonwealth Government Geologist to the Territory of Papua) and reported to the Colonial Administration in Port Moresby who, in turn, reported this discovery to the Commonwealth of Australia (Kuwimb, 1997).

Oil was first drilled in PNG during World War Two, but at a smaller scale, probably, for military use. The first commercial oil discovery under the Independent state of Papua New Guinea was in 1986 by US-based Chevron at Kutubu. This was followed by:

- First commercial exploration under independent State of Papua New Guinea was by BHP Petroleum and Partners (Australasian Petroleum Company, Chevron, Oil Search) from 1980s

- First commercial production was from 1991-1992

- Peak production 1993

- Hides Gas is small compared to Kutubu Oil

- Gobe as the third oil/petroleum project developed in 1997 (Filer and Imbun, 2009).

The first crude oil was produced in Kutubu by US based Chevron in 1992 and later bought by Oil Search Ltd (an Australian based and PNG incorporated) in 2003. The second wave of commercial exploration and production was the mega LNG project (PNGCMP, 2016).

As at 2016, oil and LNG are produced in Kutubu, Gobe Oil, and Moran oil fields. The current LNG is 9 trillion cubic feet of gas, which is expected to be produced over a 30-year 
lifespan with a projected capacity of 6.9 million tonnes per year (UNDP, 2015). Two LNG loads were shipped to the Japanese market in 2014 and 2015 respectively.

The production of oil reached its peak in the 1990s and has since slowed to about one third of its peak level. Production picked up again with first LNG shipment in 2014. Further exploration is underway for a second LNG project in Gulf of Papua. Gulf LNG is an InterOil Project-based Elk/Antelope in a joint venture with Mitsui which potentially holds 7-12 tonnes of cubic feet (Tcf) of gas - about the same size as the PNG LNG Project. The second project is the petrochemical plant owned and operated by the Singaporean-based Puma Energy located close to Port Moresby, which aimed to supply the domestic market need of about $70 \%$.

The biggest project is the ExxonMobil US 19 Billion US\$ PNG LNG. The LNG Partners include: Esso Highlands Ltd as operator (33.2\%); Oil Search Ltd (29\%); National Petroleum Company of PNG (government) (16.6\%); Santos Ltd 13.5\%; JX Nippon Oil and Gas Exploration (4.7\%); Mineral Resource Development Company (PNG Landowners) (2.8\%); and Petromin PNG Holdings (0.2\%). This is depicted in figure 3.

Figure 3. LNG Shareholders

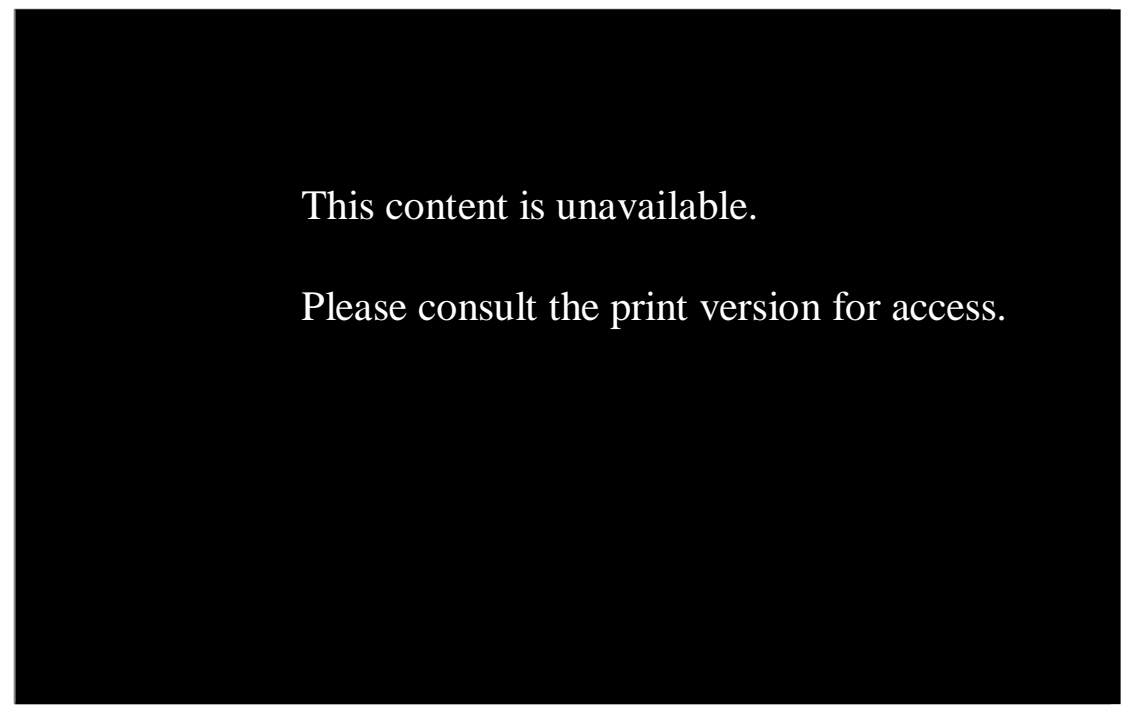

Source: PNGCMP, 2012

Other potential LNG projects include Stanley Condensate Recovery joint venture between Horizon Oil and Talisman (PNGCMP, 2012). The GoPNG has signed the Kumul Trusteeship Deed which means that "all state Trust Property will be under the responsibility of the Kumul Petroleum Share Trust. The Kumul Consolidated Holdings 
has transferred all shares issued in Kumul Petroleum Holdings to the Kumul Petroleum Trustee. The trustee is the Prime Minister of PNG (Post Courier, 2016).

\section{Energy and Petroleum Contribution to the Economy}

Petroleum is the second biggest contributor to the economy in terms of revenue while at the same time powering the economy through electricity, transportation, and provision of other goods and services such as social welfare as well as critical for national security. In aggregate, petroleum has accounted for 14 percent of the GDP, mostly from LNG (gas).

In terms of contribution to the economy through rent distribution from oil and LNG under the Oil and Gas Act 1998, the government acquires 22.5 percent. The petroleum industry contributes over K13 Billion in taxes, landowner payments, and corporate contributions. The benefits are in the form of royalties, development levies, and taxation including APT. The State then redistributes a substantial portion of these to the project area landowners, affected Provincial Governments and Local Level Governments or project area stakeholders (Oil-Search, 2014). For instance, the government also puts aside benefits for provincial and local level governments where all provincial and local level governments under Kutubu Oil Project receive 6.75 percent of the net revenues. The host provincial governments (Hela Province and Gulf) receive 2.70 percent. The resource owners under Gobe and Moran Oil Projects receive 2 percent. The total contribution to the economy is 33.95 percent. The rest is shared between IOGCs and others (ACIL Tasman, 2009).

The major streams of income derived from LNG are mainly from taxation. That is, Company Tax payable by the PNG LNG participants - PAYE or personal income tax; Development Levy; Royalty and Equity participation.

However, the information available and summarised here is insufficiently clear enough to give a true picture of the aggregate benefits to PNG. There is a significant disparity of information when comparing the resource and income sources. This dilemma has been confirmed by Margaret Callan in her findings on the contribution of mining and petroleum companies to the PNG's development (Callan, 2013). She admits that, in most cases, companies tend to have mixed reporting based on different sets of indicators, even while in the same line of business. Reporting, therefore, is neither uniform nor transparent. But the 
obvious conclusion from her data is that at least as much benefit is going to private interests as is going to the state as dividends or taxes.

Since the 1990s, petroleum has made increasingly major contributions to the economy. Beginning in 1993 petroleum exports have significantly increased from K817 million to over K2 billion in 2007 (ACIL Tasman, 2009). By 2014, the LNG added another K4.4 billion to GDP, which is 12.9 percent in 2014 budget as per first LNG production (Levantis \& Osborne, 2015). In other words, over K37 billion (US 13 billion in 2014 price) of LNG has been exported by PNG since 1993. However, NRI noted that this did not impact PNG because most of the revenues remained abroad (Sanida, 2015). Despite a drop from a predicted 21 percent GDP in 2014 due to the low price of LNG, the economy is forecast to pick up again from the LNG revenue at some time in 2018, and will continue to increase the GDP (ADB, 2016). PNG also has huge LNG reserves with underexplored coal and diminishing oil (UNDP, 2015). However, it is projected that oil will run out by 2035 creating uncertainty in the future (DNPM, 2015).

\section{Part 3. Institutions and Policy and Legislation}

This part introduces key institutions, institutional actors and discusses the policy and legislation underpinning energy and petroleum sector.

\section{A. Institutions and Their Roles and Functions}

This sub-section outlines the institutions and their roles and functions in the energy and petroleum sector.

\section{Jurisdiction}

The energy and petroleum sector is different from the mining sector - mining and petroleum were separated in 1998 by the Oil and Gas Act. Note that political and administrative agencies bear the name petroleum and energy. However, for the purpose of this study petroleum (non-renewables and liquid fuels) is the primary focus as clearly defined at the beginning of this chapter. The energy and petroleum sector is under its own ministry but also intersects with other ministries such as mining and public enterprises and 
state investment. The government agencies responsible for the sector are the Department of Petroleum and Energy (DPE) supported by the Department of Public Enterprises and State Investment (DPEPI). The state enterprises and government companies such as PNG Power Ltd and Kumul Holdings Ltd fall under the jurisdiction of DPEPI, although they have portfolios of petroleum and energy.

\section{Roles and Functions of the Institutions}

The Ministry of Petroleum and Energy (MPE) provides political oversight of the energy and petroleum sector. The DPE provides policy advice to the Minister for Energy and Petroleum and also performs the regulatory role in terms of licensing. The department also manages the benefit sharing arrangement in terms of royalties, dividends, and others between resource owners and the State. It is also important to note that this mandate also applies to development and management of renewable energy resources.

The Ministry of Public Enterprises and State Investment (MPESI) provides political oversight in the whole of government-business relations. The DPESI provides policy advice to the MPESI. Its main role is to provide policy and legal advice on governmentbusiness relations and investment.

The functions of PNG Power Limited and Kumul Petroleum Holdings Limited (KPHL) respectively are as follows. First, PNG Power Ltd. operates the national power grid system in PNG but it also has its own price regulation apart from the Independent Consumer and Competition Commission (Micah, 2012). It regulates power by approving licenses for electrical contractors, providing certification for electrical equipment and appliances to be sold in PNG, and providing safety advisory services and checks for major installations through a price control mechanism called maximum price average (MPA). Second, the PNG Kumul Petroleum Holdings Ltd. manages government petroleum business and shares from LNG and also operates businesses in the energy and petroleum sector (KPHL, 2016). This is further explained in the ownership of assets in the following section. 
There are also other related state agencies which play a complementary role to the central agencies to regulate petroleum and energy. For instance, the Environment and Conservation Authority (regulating environment externalities) and the Independent Consumer and Competition Commission (ensuring fair competition).

\section{Ownership of Assets}

The ownership of SoEs is clearly defined in the State of Enterprise Policy 2014. This policy established the Principles of State Ownership and Participation in Commercial Activities (the Kumul Agenda), how it should be restructured and governed which is depicted in figure 4 (Howell, et al, 2018). The governance aspect of this policy will be discussed in Chapter five.

Figure 4. Proposed Kumul Consolidated Holdings structure.

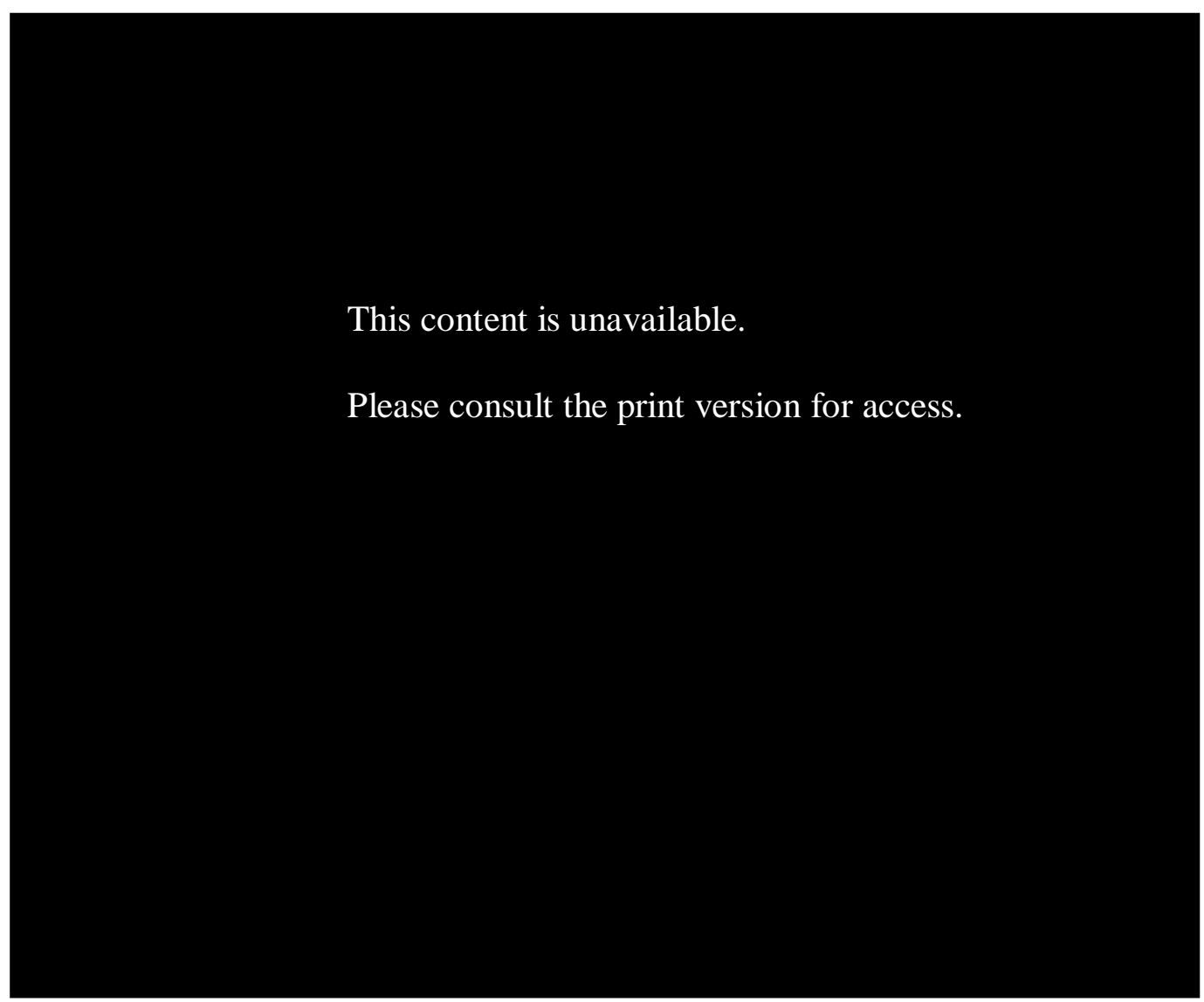

Source: Ministry of Public Enterprises and State Investments (2014) p 72.

The proposed Kumul Consolidated Holdings ( $\mathrm{KCH})$ composed of three entitities: Kumul Corporations Holdings; Kumul Petroleum Holdings (KPH); and Kumul Mineral Holdings (KMH). The Kumul Coporations Holdings was replaced with Kumul Consolidated 
Holdings ${ }^{18}$, while the other two remain the same. The $\mathrm{KCH}$ manage non-petroleum and non-mineral assets. The Kumul Petroleum Holdings (KPH) and Kumul Mineral Holdings $(\mathrm{KMH})$ manage State interests in the extractive sector. KPH constitutes subsidiaries, Kumul Petroleum Investments. It also partners with the private sector in a number of projects. It currently holds $16.57 \%$ share in PNG LNG Ltd. KMH primarily manages the portfolio of mineral interests. The Kumul Resource Development Company is owned by the State with its main function being the management of Landowners equity held on trust by the politically-appointed trustees governing the decisions (James, 2018). KPH and KMH pay substantial dividends and taxes to the State. Petroleum and Minerals are, in principle, owned by the State. The State grants the rights to explore for, extract and exploit minerals and oil and gas. It retains the right to buy back a percentage of the permitted enterprise at cost (Howell, et al., 2018). PNG Power under proposed Kumul Corporations Holdings (now Kumul Consolidated Holdings) by operation of this structure is also expected to meet electricity demand in PNG. This is to be accomplished through the DMO (Domestic Market Obligation) under LNG agreement. That is, gas from LNG is to be supplied by a new company jointly owned by Oil-Search Ltd and KPHL to power electricity in PNG (KPHL, 2015; The National, 2019; The National, 2018).

\section{B. Other Stakeholders}

The other stakeholders involve civil society (UNDP, 2015). The political context in which policy is designed involves civil society organisations such as PNG Resource Governance Coalition, Transparency International PNG and the recently formed Extractive Industries Transparency Initiative (EITI). EITI was set up in 2013 by the PNG government upon the advice of the World Bank to promote revenue transparency and accountability in the country's mining and petroleum sectors. EITI's influence in terms of power is low compared to PNG Chamber of Commerce and PNG Chamber of Mines and Petroleum. Nevertheless, the ruling government, driven by political parties, appears to dominate and influence the design and establishment of policies and legislation as is the case in most resource-rich countries.

\footnotetext{
${ }^{18}$ It is a trustee holding company for 9 (nine) State Owned Enterprises (SoEs) operatinng in agriculture, aviation, banking and financial services, insurance, maritime infrastructure, power, post and logistics, telecommunication, and water and sanitation. The company also acts as the manager of infrastructure projects throughout PNG such as hydroelectric power facilities, metropolitan sewerage systems property and port developments $(\mathrm{KCH}, 2018)$.
} 


\section{Policy and Legislation}

In order to understand the energy governance framework in PNG, it is worth tracing its historical context. Kuwimb (1997) notes that political sovereignty (which includes legal jurisdiction) over petroleum resources dates back to before 1921.

\section{Pre-Independence (1922-1975)}

The regulatory framework governing the energy and petroleum sector before independence occurred during the 'Gold Rush' period in PNG (Neale, 2003; Owen \& Lattimore, 1998). The first petroleum regulatory regime was created in 1922 when the then Australian Colonial Administration enacted the oil and gas legislation (Petroleum Legislation). This Act gave the Crown absolute ownership over all metals, precious stones, coal, shale and mineral oils in or under all lands in the Territory including the right to reserve and work any of these minerals (Neale, 2003; Owen \& Lattimore, 1998).

By 1938, a comprehensive Act on Petroleum for Papua and New Guinea was enacted. This was superseded in 1951 with a consolidated Act on Petroleum for Papua and New Guinea after both territories were united in 1949. Kuwimb (1997) noted that the new Act did not introduce new provisions except for incentives to encourage exploration.

\section{Post-Independence}

After independence, the 1951 Act was replaced by the Petroleum Act (1977), which included new incentives for exploration. The Morauta government passed the Oil and Gas Act 1998 as part of the major economic policy reforms undertaken to recover from economic crisis left by the Skate's government, and this was replaced by the Somare government's Petromin Act (2007). This Act governs the exploration for and production of oil and gas and the grant to traditional Landowners and Provincial Governments and Locallevel Governments of benefits arising from projects for the production of oil and gas. The Petromin Act renders the State as the principal nominee representing the people of PNG, with exclusive rights to explore, develop, commercialize and hold equity of all oil and gas in the country (Deszcz \& Ladbury, 2006). In 2007, the Somare government also established the Independent Public Business Corporation (IBPC) to coordinate the commercial 
activities of SoEs. Through IBBC, Arthur Somare, Minister for State Enterprise and Public Investments secured the first onshore LNG project from the previous unsuccessful Queensland LNG Pipeline under the Mekere government and Sir Moi Avei as the Minister of Mining and Petroleum (The National, 2016a).

In late 2015, the O'Neill government introduced a further set of key policies and regulatory regimes: Kumul Holdings Act 2015; Sovereign Wealth Fund 2015; Extractive Industry Transparency and Initiative and PNG Energy Security Policy 2016-2020. These policies and laws govern and manage LNG energy in PNG. One important piece of legislation is the Kumul Holdings Act 2015, introduced by Ben Micah as the then Minister for Public Investment and State Enterprise, which legally subsumed all government businesses including National Petroleum Company of Papua New Guinea (NPCP), IPBC, Petromin, Mineral Resource Authority and state enterprises. The Kumul Petroleum Holdings Limited Authorisation Act 2015 is part of the overarching Kumul Holdings Act 2015 that replaced NPCP Holdings Limited and established the Kumul Petroleum Holdings Limited as the PNG's National Oil and Gas Company (NOC) (The National, 2016b; KPH, 2018).

These Acts provide the legislative arrangement for the regulation of the energy sector. My own assessment of this new arrangement in terms of change in legislation and institutions is that it realigns all of the government's petroleum businesses under one umbrella for efficiency and effectiveness in a single coordinated framework. Government businesses have been operating with a lack of governance oversight. That is, lack of adequate supervision and decision-making related to strategic direction, financial planning, and bylaws (policies of SoEs). Therefore, these SoEs are seen to be incapable of operating in a competitive market environment. For instance, government business in the petroleum sector has been confronted by corporate governance challenges as a result of having uncoordinated business entities with different shareholders. Almost all SoEs faced insolvency. PPL to date has been unable to provide sufficient electricity to power the economy and households. There are ongoing problems of power blackouts and corporate governance issues (Matui, 2010). It appears that lack of compliance is the main governance problem in PNG.

In summary, the energy governance framework of PNG is adopted and adapted from an Australia-Anglo legal perspective on how best to govern energy. 


\section{Future Policies, Legislation and Institutions}

The first energy security policy was drafted in 2006 by DPE, perhaps a consequence of Energy Conservation Strategy of 2001 which coincided with Rural Electrification Policy of 1993 (SPC, 2012). In 2016, the government through the DPESI and DPE developed the National Energy Security Policy 2016-2020 which would see the institutional realignment in the petroleum and energy sector. This will be established by the Energy Security Act 2016, and subsequent Acts. The policy was finally approved by NEC in 2018. The Act is yet to be passed by the parliament. The key features of the policy involve policy and legislative arrangements on how best to manage and regulate energy (non-renewable and renewable energy) in PNG. The objective is to promote a balance between economic growth and climate change. This is discussed in Chapter seven.

In the preceding section, I have laid out PNG's political and economic system and energy petroleum sector in terms of its history, institutional structures, and policy and legislative arrangements. In the next chapter, I will review what has been studied about the governance of energy security in PNG.

\section{Conclusion}

This chapter presented a background of PNG, its geography, economy, history, politics, and government system in which political governance of energy security is set. It also introduced the political economy of energy and policies, legislation, and institutions in which energy is politically governed at the institutional level. 


\section{Chapter 4: Research Design and Methodology}

Chapter four describes the research design and method used in analysing how political governance of liquid fuels contributes to energy security in PNG. It follows from the research questions of this study:

How does governance of energy at institutional level contribute to energy security?

And the secondary questions: How has energy security been managed? Have any actions been particularly successful in achieving energy security? How might we improve governance of energy in terms of decision-making, policy-making and regulatory (legal) aspects of energy security?

This study was conducted in PNG to understand how political governance of liquid fuels has contributed to energy security. The investigative research design developed to achieve the aim of this study is premised on a philosophical world view, method, levels of analysis, data, and analysis.

This research is approached through a qualitative interpretative worldview involving field work and document analysis, backed by a critical review of the literature on the political governance of energy security in PNG. The research aims to fill a knowledge gap in our understanding of the relationship between energy governance and energy security identified in the previous chapter by providing new insights into the questions above.

The chapter has six parts to it. Part one outlines the research strategy. Part two focuses on the research design framework. Parts three to five set out the detailed research methods from data collection to data analysis respectively. Part six reflects on the challenges of the research.

\section{Part 1. Research Strategy}

The socio-politically constructed nature of the energy governance processes and structures my research aims to explore require a constructivist approach. I have worked in the public management field in Papua New Guinea and in the areas of energy management, which makes me an insider researcher (Miles \& Huberman, 1998; Denzin \& Lincoln, 2008). Although my research strategy can benefit from this insider knowledge because I have some understanding of the actors and institutions at work in the field, it also needs to be managed to limit the potential for bias. That is, an approach to data collection and data 
analysis that manages this risk is needed. For these reasons my constructivist strategy (Crotty, 1998:3) consists of collecting data from three sources: i) official documents that set out the formal governance processes and institutions of energy governance; ii) interviews with other actors in the energy governance field and iii) secondary analysis of these processes and institutions and how they operate in the PNG context. I elaborate on these elements in the detailed research design in the next section.

\section{Part 2. Research Design}

The elements of the methodology applied in the research project (summarised in Figure 2) are explained individually in each part of this chapter.

Figure 5: Summary of the research methodology

\begin{tabular}{|ll|}
\hline Element & Summary \\
\hline World View & Interpretive (Punch, 2014 \& Creswell, 2014) \\
\hline Method & Critical Case Analysis (Ragin \& Becker, 1992; Stake, 1995) \\
\hline $\begin{array}{l}\text { Level of } \\
\text { Analysis }\end{array}$ & Institutional Level \\
\hline Data Analysis & Content Analysis (Bowen, 2009) \& Thematic Analysis (Berg, 2009) \\
\hline
\end{tabular}

\section{A. Philosophical World View}

A worldview is informed by three philosophical assumptions, namely ontology (nature of reality), epistemology (relationship between the researcher and reality or knowledge and its limitations) and a methodology which leads to the methods that can be used for studying the reality. The first two assumptions then inform the study approach or research method/methodology (Creswell \& Race, 1999; Creswell, 2014; Punch, 2014).

Within the scholarship on public policy, three traditional world views are dominant: interpretivism, positivism and critical perspective (e.g. Wayne \& Knutsen, 2007). In pursuit of understanding the governance of energy security, which remains yet underdeveloped in PNG, interpretivism is best aligned with a worldview that recognises the socially constructed nature of this phenomenon (Creswell \& Race, 1999; Creswell, 2014; Punch, 2014). There are three reasons why interpretivism is chosen as the most appropriate 
perspective for this study. First, interpretivism helps interpret how energy governance contributes to energy security. Secondly, interpretivism seeks to build and develop existing theory through rich perspectives on an underdeveloped discourse of energy security. Thirdly, interpretivism is best aligned to exploration of 'how' type research questions (Yin, 2009).

\section{Part 3. Research Methods}

The research method uses a critical case analysis informed by thematic analysis of key informant interviews and document analysis.

\section{A. Critical case analysis}

My research question creates the need to explore and gain an understanding of how political governance of liquid fuels contributes to energy security in PNG. A critical case analysis is used to test or build a theory based on critical/information rich/revelatory/unique instances/occurrences (Ragin \& Becker, 1992; Stake, 1995, 1998). Thus I have selected for this research a critical case by focusing on energy governance in PNG between 2002 and 2017. This critical case analysis consists of examination of the specific institutions (political and economic) and processes of energy governance in order to explore the question of how governance of energy in institutions contributes to energy security.

There are several reasons why this method is appropriate in this study. First, a critical case analysis helps a researcher to identify a problem and its root causes within a case of interest (Ragin \& Becker, 1992; Stake, 1995, 1998). In so doing, it helps in the designing of objectives that are aligned with the question of inquiry. Second, once a problem is identified it would be much easier to explore and interpret the observed facts (critical instances) within a theoretical framework. Lastly, a critical case is useful to build or confirm an existing theory, in this case, political economy (political and economic) assumptions (Ragin \& Becker, 1992; Stake, 1995, 1998). In so doing, it avoids the pitfall of a single case study generalisation.

My selection of the years 2002 and 2017 for my critical case is based on my preliminary assessment of the history of energy governance in PNG. Critical cases are chosen because they involve significant changes in policy and institutional arrangements relating to the 
governance of liquid fuels and, therefore, are assumed to be important for understanding energy security (Eisenhardt, 1989). Of relevance to the selection of 2007 as the start date is that the Somare government introduced Petromin Ltd in 2007 to manage all mining and petroleum business activities on behalf of the people of PNG. The governance institutions created under the Somare government were later reorganised by O'Neill government in 2015. The latter changes are of interest to this research because at the time and subsequently there has been public criticism of the suitability of the governance changes for serving the good of the PNG people.

In addition, my insider perspective leads me to hypothesise that studying changes to the governance institutions and processes across this time period would be likely to provide insights into the governance of LNG and energy security. The change events in this time frame were substantial and the outcome has been significant to the people of PNG. For instance, development outcomes appear less positive as a consequence of poor management of oil rents from LNG after changes made in 2015. Could the governance institutions and processes tell us about some possible explanations for this? The latest report on the government spending during the resource boom from 2004-2016 in the Development Policy Blog (Howes \& Fox, 2016) also confirms the significance of the 2015 changes in the governance arrangements because there was less control in the fiscal budget (in terms of spending and borrowing) towards the end of the boom. Again, what role did the governance change play? Therefore, it would inform my research questions to understand the institutions of governance and processes created by these two governments under which this pattern is produced.

In summary, two of the more active political periods of creating institutions and processes for energy governance occurred during the 2002-2017 period, under the prime ministerships of Somare and O'Neill. Therefore, in analysing governance of energy security within this period we may expect to provide a critical case for analysis in terms of the political-policy dynamics at play in energy governance and the creation of energy security. 


\section{B. Data collection}

\section{Research protocols}

Prior to the fieldwork, research protocols were developed. These were observed throughout the conduct of the research. They aided in the design and review procedures for the identification and selection of critical documents, events, and interviewee subjects. One purpose was to manage any potential for bias through the use of focus questions, note taking mechanisms and maintaining case databases and chains of evidence to ensure and enhance the reliability of the research as proposed by Gerring (2007) and Yin (2014).

\section{Participants}

PNG's capital city and National Capital District is the host of governing institutions, IOGCs and NOGC, CSOs, research institutes, academics, and landowners. For the reason of proximity to key people and resource constraints, my fieldwork was limited to this location. In my research, I aimed to interview a range of people playing roles and experiencing governance in order to gain a fuller and more holistic perspective on LNG governance. The resources available for this research did not allow travel outside of PNG, or into the host provinces of LNG. This latter gap is mitigated by the fact that landowners from the LNG host provinces often reside in the city awaiting their royalties and dividends. The reason I have chosen these particular participants is because of their experience and expertise in the governance of LNG energy. In total twenty (20) people were interviewed. They were mainly senior officers of the government institutions, senior CSO officers, senior academics, landowners, and the chief of landowner associations. Unfortunately, no participants from producing institutions were available, due to time limitations and work commitments. As a substitute, some of the speeches presented during the 2017 Petroleum and Energy Summit in Port Moresby by the head or senior officers of these institutions were acquired for analysis. Interviews were done formally and informally through the office, email or written (Appendix 7 shows the list of participants interviewed and participant codes). 


\section{Recruitment}

As described generally above, the participants sought were those involved directly or indirectly with the political governance of energy security, especially those in the energy (petroleum and oil and gas) sector and related sectors (government agencies). They were identified and categorised into seven groups namely: state institutions (other petroleum energy related government agencies); regulating institutions (government agencies that regulate petroleum energy); revenue-generating institutions (petroleum SoEs \& government agencies that manage LNG revenues and collect tax); producing institutions (IOGCs \& $\mathrm{NOGC}^{19}$ ); civil society institutions (inclusive of the landowners' association); research institutions; and academia (see Appendix 1 for a full list of participants). I identified the participants both through my personal and work networks and through systematic identification of key people within key organisations. I used this strategy of recruitment with an open mind for the purpose of avoiding the bias of interviewee selection (Crotty, 1998). A request for an interview was made through email, hand delivery of a letter and or a direct personal approach at the 2017 Petroleum and Energy Summit in Port Moresby, PNG.

The letters introduced the researcher and explained the purpose of the research. Participants were assured that the research was an academic exercise with the objective of contributing to improving the energy governance and energy security and not a fault-finding investigation. They were also advised that participation was voluntary and they could opt out of this exercise anytime. Therefore, the consent forms were attached to the letters in order to secure participants' consent or otherwise. The participants were advised through the letters that their views and opinions would be treated anonymously. Each letter was accompanied by a questionnaire. Participants were also requested to choose their preferred dates for the interviews within a period of a month and their preferred venues (Refer to Appendix 1-5 for research protocols such as confidentiality, a letter written to institutions requesting an interview, participant information sheet and letter on request for an interview).

Those who responded were interviewed or asked to respond in writing. Some of the key participants in energy governance such as Ministers, Secretaries, and senior officers were not available for the interview because the fieldwork was conducted at the peak of the 2017

\footnotetext{
${ }^{19}$ Note that PNG NOC does not produce oil and LNG, it is responsible for managing the state's equity.
} 
PNG National General Elections. To compensate for this limitation, official reports, research reports and other documents, including media reportage, were obtained for analysis. Out of the 22 participants who responded only 20 of them participated in the interview.

\section{Interview preparation}

Interviews were conducted using open-ended and semi-structured questions. The reason for the adoption of this format was to ensure there was maximum opportunity for the interviewees' perspective to be evident without undue shaping by the interviewer's questions being too structured. This method is also appropriate in this context because it helps the researcher to interview participants once, instead of using many interviews and reliable and comparable data (Bernard, 1998). The interview format ranged from more formal to more informal face-face discussion and sometimes written exchanges via emails. The latter was the case for those participants who could not turn up for the interview due to work and other commitments. Following the interview process, as a researcher, I also recorded (written) my own general observations about the interviewee's perspectives and collected documents related to the participants' responses (Robert Wood Johnson Foundation, 2017).

The interview schedule was based on semi-structured interview questions in addressing the research questions. The benefit of using it is that allows the participants the freedom to express their views in their own terms but it can also provide a reliable and comparable data (Robert Wood Johnson Foundation, 2017). To elicit frank responses, the interviews were conducted in both formal and informal settings, in the form of a conversation. The participants were advised that they could avoid questions that they felt inappropriate; to avoid judgments if possible and to ask for clarification should there be a need. The justification for allowing interviewees to avoid questions is because management of LNG energy is a sensitive topic and government officers, including other participants, may not have been willing to cooperate unless their confidence was gained. 


\section{The Interviews}

The interviews took place over three months on dates chosen by participants, though there were slight adjustments in some cases to accommodate changing schedules. Most of the participants chose their offices as preferred venues. The interviews were not recorded, out of deference to interviewee sensitivity. The substance of the conversation was recorded by writing directly into a notebook as the participants spoke. The interview was conducted in English. Participants were also asked to do a brief write-up based on the questions through email correspondence. The ability of the landowners to comprehend English, too, has made the task easier and these written responses provided another source of data. Interview times ranged from 30 minutes to an hour depending on the participant's willingness to engage in wider conversations. Also for sensitivity reasons, participants were given code numbers to protect their identity. It was also observed during the interviews that participant responses to question and the topic ranged from positive engagement with the research questions to neutrality and reluctance to provide their perspectives or more than factual information.

\section{Collection of documents}

Relevant research, official reports, media reports, official policies and legislation were obtained to create a picture of the formal governance processes and institutions. These provided a backdrop against which to view the participants' perspectives. The documents also add an additional layer of validity and reliability to the interview data. Some relevant documents not easily available, especially policies and legislation were collected during fieldwork from the interview participants. Online sites were also used for legislation, policies and organisation reports. However, many of the official documents such as minutes, briefs and reports were not accessible due to state classification, poor record keeping of government departments and perhaps obscurity created by the sensitivity of the topic. I was not able to interview the research institutes in PNG. To overcome this problem relevant secondary data was searched for via the databases in Victoria University of Wellington Library, Google Scholar, journals, blogs, and media. I also searched on research institutions, IDAs, state institutions, regulating institutions, revenue-generating institutions, producing institutions and CSOs in PNG that might hold material relevant to the research. 
Out of the many documents found, 24 particularly relevant documents comprising legislation (9), government or departmental policies (3), official reports of government agencies and other organisations well placed to provide a credible view (8) and research reports (4) were subjected to further analysis (refer to Appendix 6).

These documents are based on the historical developments of petroleum and energy between 1975 and 2017 as figure 4 shows.

Figure 6: Timeline on the petroleum and energy governance regime under the Somare and O’Neill governments from 2002-2017

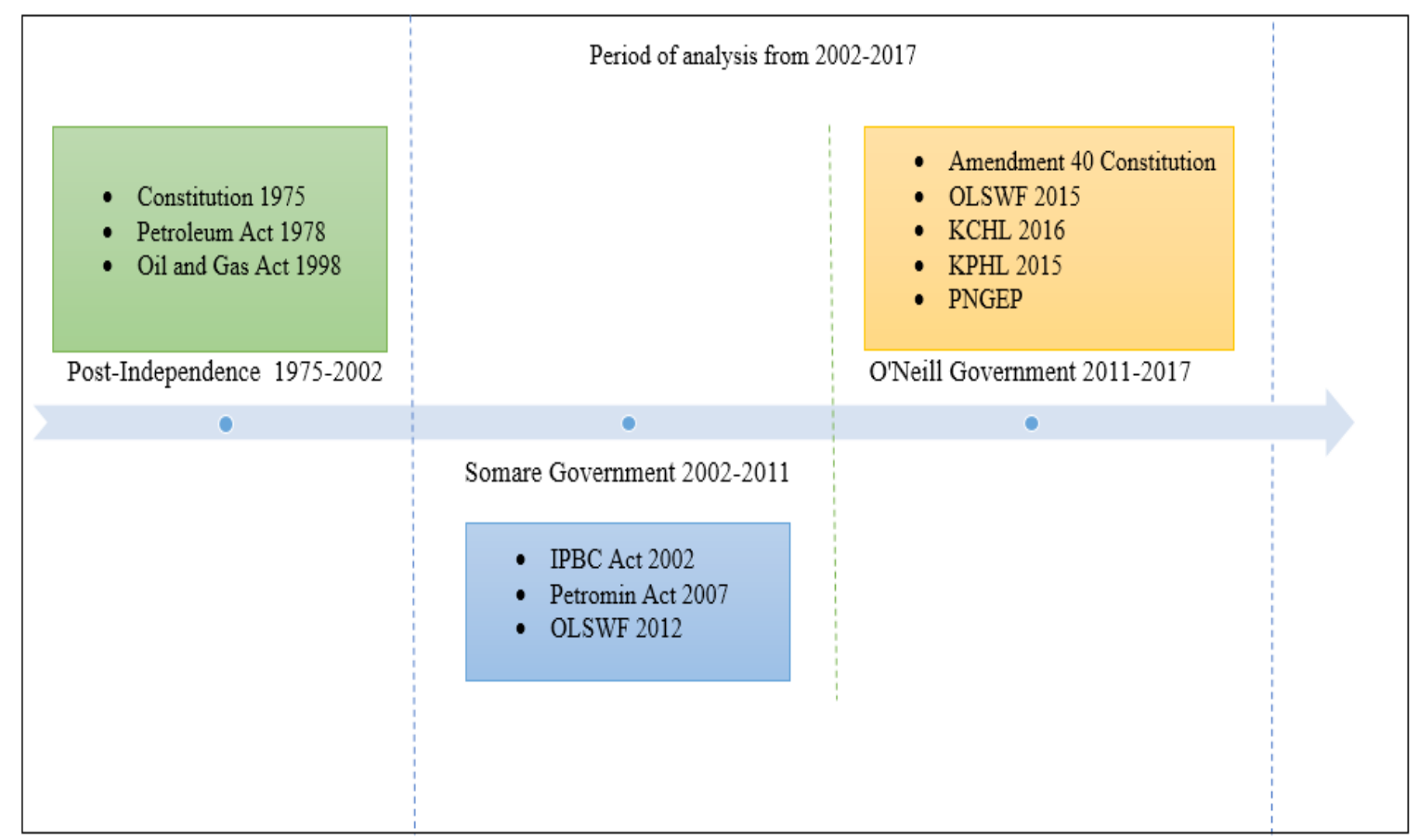

\section{Part 4. Levels of Analysis}

The levels and units of analysis of the data are outlined below:

A. Levels of Analysis: The study primarily focused at the institutional level to understand the institutional and development patterns produced by government's institutions and processes of energy governance which contribute to energy security.

B. Units of Analysis: The primary unit of analysis are the interactions between the political and economic actors and governance institutions and processes. The focus was on policies and legislation, policy and political actors and non-state actors such as CSOs and landowners. 


\section{Part 5. Data Analysis}

\section{A. Documentary Analysis}

The documentary analysis focused on key legislation, policy documents and reports. Interview participants helped me to identify the wide range of documents available. Documents considered most relevant to the research question were analysed for their purpose, key ideas and their implications. The document analysis was then synthesised with what had been said by the participants.

Bowen (2009) defines documentary analysis as a form of qualitative research in which documents are interpreted by the researcher to give voice and meaning around a research topic of interest through triangulation. Triangulation is an important technique in documentary analysis because it provides a confluence of evidence that gives credibility to the research. In so doing, it reduces the potential impact of bias in using different methods in gathering and analysing a data (Bowen, 2009). One of the strategies proposed by Bowen is content analysis. Bowen also argues that thematic analysis can be applied together with content analysis where it is helpful for recognising particular patterns in a document which is then useful for painting a broad, overall picture (Bowen, 2009). I have adopted this approach. In summary, Bowen defines documentary analysis as "evaluating documents in such a way that empirical knowledge is produced and understanding is developed" (ibid, p. 34). In so far as a document expresses both facts and emotions, not only can critical insights be derived from documentary analysis but also the mind of the author(s) can be interpreted. This latter point is very important for this research, for the purpose of attempting to hypothesise the reasons for governance success or failure. Such an approach minimises the personal bias of an emotional interviewee (participant).

The other advantage of documentary analysis is that it can be pursued as an efficient and effective way of gathering data because documents are manageable and practical artefacts reflecting the point in time at which they were written. Documentary analysis supports and strengthens the research methods and becomes a supplementary method of data collection or in providing background information in order to contextualise a research (Bowen, 2009).

In summary, a combination of content and thematic analysis was used to interpret and analyse important patterns and meaning found in the documents to flesh out and provide background to the participants' responses in order to generate a better understanding of the political governance of energy security in PNG. 


\section{B. Thematic Analysis}

Thematic analysis is a qualitative analytic method used by researchers for identifying, analysing and reporting patterns (themes) within data. It organises and describes data set in (rich) detail but it can also move beyond this by interpreting themes from various aspects of the topic as well (Berg, 2009). In this study, thematic analysis was used to draw together threads that when seen together make a more of pattern in the data.

\section{NVivo 10 Software Program}

NVivo 10 Software Program was used as way of storing, managing and analysing data (Bazeley, 2007; Lewis, 2004). Butler and Lavery (2012) argue that the outcome of the research using this software really depends on the researcher despite its capacity to record, store and generate qualitative data. Based on this advice, a blank file known as a project journal was opened for data entry. This journal was not only given a title where raw data were recorded but for keeping track on the questions, ideas and reflections in the process of data analysis. The steps I used to analyse my data using NVivo are described.

Firstly, I used my research questions to create five nodes (see appendix 8A) for the main themes, namely: political governance of energy; policies, legislation and institutions; management of energy security; government responses to energy security and best approaches to energy security. In the process of coding the data to these large theme nodes, several subthemes emerged and were added as sub-nodes under their respective themes. Thirdly, as coding proceeded, relationships between the subthemes under the main themes became more visible and interrelationships were established allowing for the identification of nodal trees. The above process was repeated several times to confirm or verify the themes, subthemes and their interrelationships for interpretation. The emerging themes were coded through a mapping tree as shown in the Appendix 8B-E. The final thematic structure was then imported as tables for analysis in Chapter 6.

The data analysis method described above enabled a form of (re)construction of social reality in the petroleum and energy sector. Participant's views in this sector were subject to their own interpretation of realities that are influenced by their world views and background and positions held in respective institutions. In order to create the narrative in 
Chapter 6, I have interpreted participants' views and constructed them as evidence to understand how political governance of energy has contributed to energy security.

\section{Theoretical Application}

To answer the research questions, this study applied a political economy perspective as discussed in Chapter three. In so doing, it complemented QEGF in discussing the streams of data in Chapter seven and draws the conclusion in Chapter eight. The use of this strategy is inspired by Crotty's method of positioning the philosophical stance within the research design (1998:3). In other words, it bridges the theoretical and empirical part of the study in the interpretivism tradition.

\section{Part 6. Managing Research Challenges}

Several challenges were encountered during the course of the data collection and data analysis. In order to manage them, a reflective strategy was used (Al Makhamreh \& Lewando-Hundt, 2008; Labaree, 2002; Paechter, 2013; Rogers, 2012; Taylor, 2011). Reflectivity ensures 'neutrality' in the conduct of the research. In so doing, it avoids obvious, conscious or systematic bias and enables the researcher to be as neutral as possible in the collection, interpretation and presentation of data. However, as a 'research insider,' I have recognised that sometimes it is quite challenging to be as neutral as possible or objective in the research. A research insider is defined by Jenkins (2000) as a member of an 'in-group' with access to its past and present, who shares experiences with the research participants.

My insider status as a public servant is clearly based on multiple commonalities with my participants, such as shared culture, language, religious beliefs, educational experiences, profession, work roles and responsibilities, collegial relationship, daily activities, and lifestyle. The commonalities led to some of the dilemmas I experienced during the process of my data collection and data analysis. For example, I was struggling to separate myself from personal opinions as recorded in my project journal.

During the course of the data gathering process, I regularly reflected on data gathered after each day of interviews. This enabled me to try to make more sense of the data as I proceeded, reflect upon the insights gained and also use this for reference in subsequent 
interviews. The transcriptions of the data helped me to reflect on participants' words and meanings based on their experiences. Hence, in the process, the participants revealed more to me and allowed me to make sense of their world (Creswell, 2003). This reflexivity greatly helped me in avoiding potential biases and report alongside the research details.

\section{Conclusion}

This chapter presented the research design and method used to collect and analyse data on the fieldwork and the researcher's reflections on fieldwork experiences. Given the various documents especially legislation, policies and reports, I have applied a combination of research methods to categorise, analyse and interpret the findings.

The process of locating, reviewing and accessing those documents and managing the risks of insider research was also described in this chapter. 


\section{CHAPTER 5: LNG ENERGY GOVERNANCE FRAMEWORK}

This chapter presents an analysis of the important institutional and regulatory frameworks, laws, regulations organisations, policies and laws governing the LNG energy in PNG. Out of the many documents, 24 particular relevant legislation (9), policies (3), official reports (8) and research reports (4) were identified. However, only legislation and policies related to legal entities and legally binding processes and institutions are analysed. The reports are analysed in chapter two (as summary) and appendix 9. For each document a purpose ${ }^{20}$ is first identified. Then particular parts of each document deemed relevant to the research question are commented upon and finally the implications of the documents for the research are discussed.

The purpose of this chapter is to lay out clearly the formal governance framework and how it operates, and the extent to which it might likely produce energy security outcomes.

\section{Part 1: Legislation}

Nine pieces of legislation and the Constitution are analysed as legislation directly related to the Governance of energy in PNG. The nine are: National Constitution; Constitutional Amendment Number 44 on Organic Law on PNG's Ownership of Hydrocarbons, Organic Law on Sovereign Wealth Fund 2012 and 2015 (OLSWF) ${ }^{21}$; Oil and Gas Act (OGA) 1998; Independent Public Business Corporation Act (IPBC) 2002; Petromin Act 2007; Kumul Consolidated Holdings Act (KCHA) 2016; Kumul Petroleum Holdings Authorisation Act (KPHA) 2015 and the Unconventional Hydrocarbon Act (UHA) 2015. The selection of these particular pieces of legislation and the Constitution is based on the timeframe (20022017) of this study. Only sections of legislation specific to the context of political governance of energy security are examined in detail.

\footnotetext{
${ }^{20}$ Note that some of the purposes are explicit whilst others are made implicit by their Statements.

${ }^{21}$ There are two versions of the OLSWF. The first version was legislated by the O'Neill government in 2012 (OLSWF 2012). In 2015, the same government amended it (OLSWF 2015). The Organic laws on SWF are discussed in this chapter.
} 


\section{Section1: Papua New Guinea Constitution and National Goals and Directive Principles (NGDP)}

The Constitution was adopted in 1975 based upon the Constitutional Committee (CCP) recommendations. The NGDP of the Constitution are important in this research. Therefore, it sets the governance framework for the political governance of liquid fuels in the context of energy security in PNG.

\section{Purpose of the NGDP}

The Constitution of PNG is best described as a political roadmap that not only established the Independent State of Papua New Guinea and its political and legal systems but also prescribed the type of society people aspired to have. It is the supreme legal foundation on which it could be expected all other laws are derived and operational from since 1975. In its origins, this legal foundation is based on the NGDP and Basic Social Obligations (BSO).

The NGDP and BSO are the two most important bodies of underlying goals and principles based on PNG's social and cultural orientations. These goals and principles ultimately set out how PNG aspires to be an independent nation after the Australian Colonial rule. They are the preamble of the Constitution (Kari, 2005; Narokobi, 2016).

According to Narokobi (2016), the implementation of the NGDP and BSO is a constitutional duty provided for by subsection 25 and subsection 63 of the Constitution. That is, there are avenues in which governmental bodies can effectively implement the NGDP and BSO in compliance to the Constitution in an indirect justifiable way. Therefore, the government as an agent of the Independent State of Papua New Guinea is required by the Constitution to do so through policies and laws. In this respect, all laws and policies and plans are developed and operationalised by the government in the true spirt of the Constitution accordingly. However, these provisons (ss $25 \&$ ss 26 ) are not enforcable in a court of law, in my view; that is to say that the government will not be held accountable if it fails to do so.

Together they established the legal and regulatory framework on which existing laws define and govern the existence of the State and operation of the government (Narokobi, 2016). 


\section{Specific sections investigated}

In light of the Constitution, it is appropriate that the NGDP are examined first in this part.

\section{Significance of NGDP}

The NGDP provides the philosophical foundation on which the government governs and manages the energy sector in PNG as stated above. Therefore, the political governance of energy (liquid fuels) is derived from the NGDP of the Constitution. More precisely, Goal 3 and Goal 4 of NGDP clearly lay out the parameters by which the government should prudently govern and manage natural resources (both non-renewable and renewable):

- 'Goal three (3) provides for the Government to base their planning for the political, economic and social development and take effective measures to control and actively participate in the national economic, and in particular to control major enterprises engaged in the exploitation of natural resources.

- Goal four (4) provides for Papua New Guinea's natural resources and environment to be conserved and used for the collective benefit of all, and be replenished for the benefit of future generations. ' (Government of Papua New Guinea, 2014; Narokobi, 2016).

These goals and directive principles have been the underlying philosophy of development policies, plans, and legislation and in this case, governance and energy security. The government is required by the Constitution to provide a stable political and economic environment through which fair policies, plans, and laws will empower every citizen to actively participate and benefit from the resources in a sustainable way. In other words, NGDP \& BSO are the tones of moral and ethical framework set by the Constitution within which the government should conduct itself with respect to its subjects and the resources. They are basically the cornerstones of prudent governance; resources and benefits must be seen to be well managed by the government for and on behalf of the people of Papua New Guinea and distributed equally to the society. The government in this regard must be seen to be acting only as the custodian of the resources and benefits for and on behalf of the people.

This underlying philosophy has inherent implications for the notion of ownership of resources in PNG. Apparently, landownership will help us to understand the relationship 
between governance, development and national security. Therefore, it is worth briefly discussing the significance of the legal basis of the resource ownership.

The Colonial Administration and Government of PNG have claimed absolute right over most strategic economic resources for political and economic reasons as stated above. And this was done by introducing legislation claiming ownership of any minerals and petroleum or oil and gas by the Crown and State. But there appears to be a conflict between traditional landowners and the State in the context of benefit sharing under the legislated arrangement. Therefore, the implications of this legislation should be critically analysed in light of the energy security.

\section{Land Ownership}

Land in PNG is not only sacred but is attested to the social, spiritual and religious significance of the PNG society. Long before the arrival of European colonisation, land was traditionally owned communally. The ownership of land was passed down from generation to generation. And that is the reason why almost 80 percent of the land is still owned by the customary landowners. However, this notion of land ownership was disputed with the introduction of the Western philosophy (Kuwimb, 1997). It is the clash of these two conflicting Melanesia and Western worldviews that have given rise to some of the development issues faced in PNG as shown in the following sections. The general notion is that customary land is under communal ownership, meaning land is owned by the community, tribe or clan and not really the individuals. A clan member is entitled or has usufructuary rights over tribal land and so forth. However, in the context of resource development, the current law clearly provides for the State the right of ownership over mining and petroleum assets as discussed throughout the thesis. [See Armitage (2001), Glaskin, (1992) and AusAID (2008) on customary land ownership in PNG.]

\section{Legal Basis for the State Ownership}

The ownership of resources found on customary land ${ }^{22}$ by the State was legalised under the first Mining Ordinance of 1907. This Ordinance gave absolute right of ownership of

\footnotetext{
${ }^{22}$ Refers to the State ownership of petroleum and mineral (subsurface, except in the case of alluvial gold where local landownership extends to the first $6 \mathrm{~m}$ depth) with the surface land rights. Where a developer is
} 
Petroleum resources to the Crown in the Territory of Papua and divested customary land ownership (Kuwimb, 1997) ${ }^{23}$. Section 1 of the Mining Ordinance 1907 provided that "All mineral gem and precious stones or under native lands shall after the passing of this Ordinance be the property of His Majesty”. This has been the legal basis to all other amended versions of the Ordinances or pieces of Legislation until 1975 where resource ownership is vested with the Administrator or the Crown.

In 1975 when PNG became independent, the resource property rights were transferred to the PNG Constitution. Two sections of the Constitution provide for the State Ownership: Section 248 of the Constitution provided that: "All property that was, immediately before Independence Day, vested in the body corporate at that time known as 'The Government of Papua New Guinea, is, on that day, vested in Papua New Guinea, and all rights and liabilities...of that body immediately before that day are, on that day, rights and liabilities of Papua New Guinea." similarly, Section 2 of the Constitution declared that the State has permanent sovereignty over natural resources within its territory.

However, in the absence of section 284, section 2(2) of the Constitution confers general rights over resources in the State, which declares that the State has permanent sovereignty over natural resources within its territory. Thus, this provision states that the sovereignty over natural resources is, and shall, remain an absolute, subject only to the international law obligations that are freely accepted by PNG in accordance with the Constitution. According to the Constitutional Planning Committee (CPC), this provision is to ensure that PNG exercise its right to have effective control over this resources and their exploitation as a free and sovereign nation (Kuwimb, 1997).

Several other provisions under different Mining and Petroleum Acts provide for the same (right):-

- Section 5 (1) of the Petroleum Act Ch. 198 - which states that “...all petroleum and helium at or below the surface of any land is, and shall be deemed at all times to have been, the property of the State."

- Section 5 (1) of the Mining Act 1992 - which states that “ all minerals existing on, in or below the surface of any land in Papua New Guinea, including any mineral

interested in investing in minerals or petroleum, the State, which claims sovereignty, (and which landowners do frequently contest) must first negotiate with the customary landowners to access their land.

${ }^{23}$ See also Filer, 1997 and Weiner and Glaskin, 2007. They also provide interesting insights into ownership issues. 
contained in any water lying on any land in Papua New Guinea, are the property of the State."

- Section 6 (1) Oil and Gas Act 1998 - which states that "Subject to this Act, but notwithstanding anything contained in any other law or in any grant, instrument of title or other document, all petroleum and helium at or below the surface of any land is, and shall be deemed at all times to have been, the property of the State."

\section{Government Justification for State Ownership}

There are three main justifications for the government's claim of State Ownership. The first reason is an economic acknowledgement that there is a prime legal entity for the State; and that entity holds assets and responsibilities on behalf of the people of PNG. The second reason is attributed to the economic development objectives. That is, where there is exploration or exploitation of minerals and petroleum, this must be done in accordance with the promotion and implementation of the national objectives of economic development. The last reason is purely for strategic purposes. That is, natural resources are a national strategic asset of the State and, therefore, must not be left to private citizens or individuals (Kuwimb, 1997). These three reasons, apparently, are policy justifications provided for by the government. The same is boldly emphasized in NGDP.

\section{Implications}

The issue of resource ownership dispute between the landowners and State and developers (companies) under the current legislation has major implications.

The first implication is that there is a dual and disputed ownership of land on which the resources are found brought about through the PNG legal system that recognises both the State Ownership of the Land (through a lease arrangement) and the Customary Ownership of the Land. Customary Law is a body of rules and norms that govern the ownership of land. These two laws operate in parallel but tend to conflict with each other on the basis of differing Western and Melanesian conceptions; the clash of the customary concept of land versus the Anglo-Australian concept of landownership. Without some resolutions of the operation of these laws, legal disputes as to who owns the land and the resources beneath are likely to continue to be a source of tension and conflict between the State, the developers and the landowners. This is the main reason why to date there have been ongoing disputes 
between landowners and the State, and developers in terms of distribution of benefits and compensation claims in and by the affected project areas.

The second implication, related to the first, when the land is taken as a commodity in an economic sense against customary ownership by the virtue of an individual and clan or tribe. When the land is commodified by the State into a monetary value via developers, the issue of benefit distribution, including moral concerns, tend to lead to tension and conflict, since the land is something defined as sacred in the Melanesian world view. When the land is commodified from a sacred value into a monetary value, the tendency for demand for equal participation by the customary landowners against a price tag in the form of an economic transaction by the capital proprietor increases as a customary obligation by virtue of customary rules and norms.

The third implication may arise as result of State failure in the distribution of equal benefits from the petroleum projects to society in light of the second implication. Since the State through the government by-law has the responsibility to do so, it has the duty within the true spirit of the Constitution to develop the land and resources beneath it and distribute the wealth equally. This is clearly articulated by the NGDP as directed by the Constitution. Hence, this may collide with the Constitution, which has been the case. The Bougainville crisis is a result of the tension and conflict between the State and developers and the Panguna Copper Mine Landowners about the unequal distribution of wealth and moral concerns in terms of sociocultural-environmental issues.

One of the important observations of the NGDP is that the State shall have absolute monopoly over the governing of resources within it in such a way as to the benefit of the State and the People or Citizens within its sovereignty. This is reflected in Goal 3 and Goal 4 of the NGDP:

'Goal 3. National sovereignty and self-reliance. We declare our third goal to be for Papua New Guinea to be politically and economically independent, and our economy basically self-reliant.

Goal 4. Natural resources and environment. We declare our fourth goal to be for Papua New Guinea's natural resources and environment to be conserved and 
used for the collective benefit of us all, and be replenished for the benefit of future generations.'

That implies that the Government shall act for and on behalf of the State in any matters defined by the Constitution. In addition, any subsidiary laws must operate within the true spirit of the framework of the Constitution. Given the supremacy of the Constitution by the hierarchy of laws, subsidiary laws in relation to the governing of energy sources may conflict with the Constitution. For instance, the notion of State Ownership over the subsurface resources is clearly guaranteed by the Constitution for the State through the Government to Act for and on its behalf. This may conflict with the current legislation governing the petroleum and oil and gas where a political head is vested with the absolute right to act for and on behalf of the State, Government and People of Papua New Guinea. I have observed that this will be a serious dilemma as analysis of the legislation will show in the next sections.

Section 2: Constitutional Amendment Number 44 (Papua New Guinea's Ownership of Hydrocarbons and Minerals and the Consolidation and Commercialisation of Papua New Guinea's Business) Law 2016

\section{Purpose}

The purpose of the Constitutional Amendment 44 is stated as 'Being a Law to alter the Constitution by providing for Papua New Guinea's Ownership of Hydrocarbons and Minerals and the Consolidation and Commercialisation of Papua New Guinea's hydrocarbons and minerals.'

\section{Specific Sections Investigated}

The section investigated is specifically Amendment Number 44 in the Papua New Guinea Constitution in particular, New Sub-division AB of Division VIII.1. where Division VIII.1 of the Constitution is amended by adding after section 212A the following new division: 


\section{'Subdivision AB. - Papua New Guinea's Ownership of \\ Hydrocarbons and Minerals and the Consolidation and \\ Commercialisation of Papua New Guinea's Business.}

212B. Papua New Guinea's Ownership of Hydrocarbons and Minerals.

(1) Hydrocarbons and minerals in their natural state are, and always, have been, the property of Papua New Guinea.

(2) An Organic Law may make further provision in respect of Papua New Guinea's business activities and interests and may provide for the disposal of, dealing with and the consolidation and commercialisation of those activities and interests.

212C. The Consolidation and Commercialisation of Papua New Guinea's Business.

(1) Papua New Guinea may undertake business activities

(2) An Organic Law may make further provisions in respect of Papua New Guinea business activities and interests and may provide for the disposal of, dealing with and the consolidation and commercialisation of those activities and interests'.

The main focus of this analysis is on the ownership of hydrocarbons in PNG and its significance for the governance of energy and energy security.

\section{Significance}

Constitutional amendment number 44 is significant to the governance of hydrocarbons particularly the ownership of them. The aim of this amendment is to clearly define the ownership of hydrocarbons through the Constitution, previously opaque in the Constitution. That is to say that the Constitution only makes reference to it in general terms. The Constitution generally defines the ownership of resources under NGDP. However, NGDPs are non-justifiable. And this could be one of the reasons why this special provision (constitutional amendment 44) was introduced. The amendment now gives absolute right of ownership of hydrocarbons to the State and the right for the State to consolidate and commercialise hydrocarbons. And in so doing, this amendment (44) now gives effect to the supremacy of subsequent legislation governing the petroleum and energy sector. 


\section{Implications}

The new constitutional amendment 44 may have implications for rights of ownership between the State and landowners and subsequent legislation governing petroleum and energy sector, in particular, the Customary Law. First, the law now effectively gives absolute right of ownership to the State over the landowners, which may conflict with the customary law. That is because the Constitution is supreme over other legislation in the hierarchy of laws. Secondly, the Constitution, by operation of the amendment 44, gives absolute right for the State to consolidate and commercialise hydrocarbons in the interest (business) of the State. It does not, in any way, clearly stipulate for the State to act for and on behalf of the people of Papua New Guinea; implicit in the constitution as a whole is that all actions taken by the institutions it establishes are undertaken for the people, as their trustees. It is not a certificate of ownership of positions, or resources. The supremacy of the Constitution effectively empowers $\mathrm{KCH}$ and KPHL to exercise its powers to conduct business.

\section{Section 3: Organic Law on Sovereign Wealth Fund 2012 and 2015 (amended)}

The Sovereign Wealth Fund (SWF) was first introduced by the Somare government in 2011 to manage the first LNG revenues and minerals in PNG. The Somare government initially proposed two consolidated funds namely, Future Fund and Infrastructure Fund. The same government also announced that the SWF would be governed by an Organic Law which would provide the requisite high level structure, governance arrangements, and policy guidance. And those other aspects of the SWF would be governed by subordinate funds. However, the original proposal's structure and number of funds had been altered when the O'Neill government took over from the Somare government in the 2011 political impasse. In 2012, the O'Neill government passed the first OLSFW. In that it replaced the future fund with a Stabilisation Fund and infrastructure fund with a Development Fund respectively. However, in 2015, the same government amended the OLSWF 2012; the OLSWF 2015 supersedes the OLSWF 2012. The reason why the OLSWF 2012 was amended is due to the procedural issue placing doubt around the law's validity.

\section{Purpose}


In order to manage the LNG revenues, the government decided to establish the SWF by an Organic Law in 2012 and amended it in 2015 as stated in precedence. The objective of the SWF is provided in section 5 of the amended OLSWF 2015:

a) To support macroeconomic stabilisation;

b) To support inter-generational equity; and

c) To support asset management in relation to assets accrued from mineral and petroleum receipts.

In light of this, the SWF was legislated as OLSWF 2012. The aim of the SWF by law is to ensure that all revenues from the minerals and petroleum flow through a stabilisation fund prior to flowing through the national budget in accordance with a specified formula. This means that, in effect, dividends from the LNG project are required to be paid into a development fund earmarked for socio-economic development.

In essence, the 2012 version of the OLSWF focused on the stabilisation fund for development purpose. However, the 2015 amendment replaced the Development Fund with a Savings Fund, which is linked to the Kumul Trust of the KCH governed by the KCHA. The NRI report (see NRI report on OLSW 2015 in Chapter six) states that the rationale of the Development Fund was to establish a dedicated source of funding for investment in high priority infrastructure development in PNG to set the foundation for sustained broadbased economic growth. The OLSWF stipulates that Savings Fund is to provide a means of preserving the real [inflation adjusted] value of extracted mineral and petroleum resources through long-term investment for the benefit of current and future generations of citizens of Papua New Guinea. This amendment to OLSWF may have implications for the governing of LNG revenues as discussed below. This also explains one of the reasons for too much policy change.

\section{Specific sections for investigation}

The specific sections of the OLSWF 2015 investigated and analysed are related to the significance and implications of the Act. The analysis focuses on the powers of SWF, Board and its composition, the appointment of the Board members, and independence of the Board, Trusts, and management of the revenues. These sections are contained in:

- Part II: The Sovereign Wealth Fund 
- Part III: Operational Rules

- Part IV: The Sovereign Wealth Fund Board

- Part V: Duties and Responsibilities of Board Members

- Part VII: Fund Managers and Custodians

\section{Significance}

The OLSWF 2015 is an important piece of legislation that supersedes OLSWF 2012 and gives effect to the operation of the SWF in accordance with these specific sections. Section 4 (1-3) established SWF in accordance with 212A of the Constitution and consists of a Stabilisation Fund and Savings Fund. Subsection 2 of section 4 provides that the money paid into or withdrawn from the Fund must be paid and withdrawn in accordance with the Organic Law. Sections 7 and 8 provide for the role and mandate of the Minister. The Minister is mandated to give an investment mandate to the Board after consultation with the Board in accordance with section 8. Sections 10-12 provide for the purpose and operation of the Stabilisation Fund. Sections 13-15 provide for the function and operation of Savings Fund.

Sections 17-20 provide for the establishment of the Board, its functions, powers and delegation of powers. Sections 21-23 provide for the membership, appointment and Chairman of the Board. The Chairman and members of the Board shall be appointed by the Head of State upon the advice of the SWF Appointments Committee in accordance with section 22 (1-28). The Chairman of the Appointment Committee is the Prime Minister in accordance with section 22 (3a). Section 23 provides for the appointment of the Chairman of the Board in accordance with the same process prescribed in section 22. Sections 36-38 provide for the Fund Managers and Custodians who shall be appointed by the Board to carry out functions as prescribed in section 36 (2) and section 38 (3-4) respectively.

There are several implications about the OLSWF. First is that, there have been two models prescribed. The first appeared in the OLSWF 2012 which proposed a stabilisation fund and a development fund. The OLSWF 2015, by contrast, comprises a stabilisation fund and a savings fund. The savings fund replaced the development fund from the 2012 Organic Law. However, since the coming into effect of 2015 Organic Law on SWF, the Government has been slow in administering this SWF model. No reasons or information have been provided by the government on the delay of such an important governance mechanism. 
The second implication is that the fund is to be managed by the Kumul Trust according to the second version of the SWF. Because the Fund is parked under the Kumul Trust, it legitimately makes the Prime Minister the sole Trustee. This opens an opportunity for the funds being used for political purposes other than the prescribed purpose as stipulated in the KCHLA, KPHLA, and OLSWF.

Third implication is that the Board of the SWF, assuming that it is established, may not be fully independent because the Prime Minister is the Chairman of the Appointing Committee of the Board. The Prime Minister in this instance may influence certain decisions of the Board in relation to the appointment and management of the Fund through his status provided for under the Act.

Finally, the development fund that appeared to be a suitable economic option has been replaced by the savings fund. According to NRI's (2014) analysis based on an economic model, the implication of this amendment is that the savings fund may not necessarily be the best economic option because future savings will be invested in an unpredictable longterm financial asset market. While the saving funds supported by the fiscal framework comprising the Medium Term Development Strategy, Debt Management Strategy, PNG Fiscal Responsibility Act 2006 and Public Finances Management Act 1995 is important for current and future generations, there is no guarantee that the accumulated equity will result in high returns. Market volatility often dictates the true value of returns. Another potential risk is that there is no guarantee that the savings fund would be wisely used. Political actors may sometimes unethically draw down savings at any time for a political purpose other than development purposes by altering the legal framework. The underlying point is that it is wise to invest in a sustainable broad-based economy given PNG's socio-economic urgency of priority needs. The past experience from the recent use of trust accounts and with the previous operation of the Mineral Resource Stabilisation Fund (MRSF) from 1974 to 2001 provides evidence to suggest that revenue management is a governance problem in PNG (PNGDoT \& BPNG, 2010).

In addition, the Deposit and Withdrawal rules of the Stabilisation Fund will reduce the 'smoothing' purpose and increase destabilisation of the fund itself because it does not target stabilisation in the event of economic surprises. Moreover, the opaque formula used in this arrangement leaves opportunities for mismanagement of Fund. Comparably, the development fund will be invested in the dire situational need of infrastructure 
development. This will generate higher returns which will be reinvested for generationalequity or future savings. It is more rational for the government to spend now than in future. The National Research Institute's (NRI) report (2015), supported by a discussion paper on SWF by the PNG Department of Treasury and Bank of PNG (2010), also pointed out these weaknesses and confirms this implication.

\section{Section 4: Oil and Gas Act 1998 and the Amended Versions}

The Oil and Gas Act (OGA) 1998 was legislated by the Mekere government as part of a major reform undertaking. This piece of legislation has been the legal framework governing oil and gas and petroleum in PNG until it was amended by the O'Neill government in 2016. The amendment that was made is section 3 of the 1998 Act in relation to the definition of "offshore area". The new definition takes into consideration of 'seabed' other than internal waters. This was done to recognise the uptake of offshore drilling.

\section{Purpose}

The purpose of the Act is provided as:

'Being an Act to enact comprehensive legislation governing the exploration for and production of petroleum (including oil and gas) in Papua New Guinea, including the offshore area, and the grant to traditional landowners and Provincial Governments and Local-level Governments of benefits arising from projects for the production of petroleum (including oil and gas), and the processing and transportation in Papua New Guinea of petroleum and petroleum products, and to repeal various Acts, and for related purposes.'

Therefore, it gives effect for the full operation of the government business in petroleum and oil and gas by virtue of the powers vested in OGA.

\section{Specific Sections Investigated}

The specific sections investigated for the purpose of this study are ownership, governance, participation and benefit sharing. The aim is to analyse the significance and implications of the provisions in the Act relating to the ownership, transparency and accountability, and 
equal participation and benefit sharing in the petroleum and oil and gas industry. These three sections are found in:

- Petroleum Ownership - section 6 (1)

- Governance - sections 11-16

- Participation and benefit sharing - section 2 and sections 165-179

\section{Significance of the Act}

The Act not only provides the legal parameters in the form of rules and guidelines on how different parties should participate and benefit from exploration to benefit-sharing but also defines the roles and responsibilities of each party in this undertaking.

A number of implications arise from the operation of this Act. The first relates to the State Ownership. This is an issue introduced in an earlier section. This Act through section 6 (1) clearly provides for the State's absolute right and ownership of the petroleum, which the customary landowners frequently contest. That is any petroleum and oil and gas elements under the land and sea belong to the State. Access to land on which petroleum is found is granted under the terms and conditions of this Act, by the award of a petroleum license. That means licensees have the right to enter and use the land for the purpose of conducting their operations. This right is granted to licensees on the condition that they provide compensation (upon negotiations) to the Customary Landowners for a period up to 25 years which may be extended for a further period of 20 years. Before issuing a license to the developer the Minister for Petroleum and Energy under section 116 (1) authorises access to land (through means of a lease upon negotiation between the State and Customary Landowners) on which the petroleum is found. Despite the fact that the Act provides for landowner identification, this has not been done for the LNG project. This is one of the major reasons why royalties have not been paid and landowners are frustrated (Minnegal, et al, 2018; Koim and Howes, 2018).

The same colonial law was transferred to the Independent State of Papua New Guinea in 1975; the Constitution provides that all laws in place prior to independence continue to be in force post-independence until altered by parliament. This particular provision is in conflict with the customary laws therefore creating a tension with the landowners. Deszcz \& Ladbury (2006) deliberate the same issue in their paper. The government has not yet made any attempt to clearly define this legal paradox. Ongoing landowner issues in the 
energy sector are a consequence of this provision. Similarly, this issue has been witnessed in the mining sector with the Bougainville crisis.

The other implication relates to governance. Here, I am referring specifically to the political governance and any conflicts there might be between the responsibilities of corporate governance and those of political governance. Section 11 of the Act provides for the governing board of revenue-generating institutions, the composition of the members, appointment, and roles and responsibilities of the board. The concern that may arise from this section is the appointment of the Chairman by the Minister responsible for the petroleum and energy. Although the board may appear to be independent by the virtue of the Act whilst, on the contrary, the Act, per se, may also become susceptible to the possibility of political interference and manipulation of the appointment and decisions of the board. This is because the Minister is part of the board. More so, this would increase the tendency for political corruption, rent-seeking, and patron-client which may affect the decisions of the board to perform independently in accordance with the prescribed functional objectives as stipulated in the Act. Therefore, transparency and accountability may appear to be issues in this respect.

Finally, the Act appears to have given fewer considerations to equal participation by the State itself and landowners given the $22.5 \%$ interest in each petroleum or oil and gas project. S165 (1) provides that 'The State has the right (but not the obligation) to acquire, directly or through a nominee, all or any part of a participating interest not exceeding $22.5 \%$ in each petroleum project'. In the case of PNG LNG, the $16.6 \%$ State and $2.8 \%$ customary landowners' interests in the form of equity appears to create an imbalance between the State and landowners and IOGCs because almost three quarters of the share of the pie is owned by the IOGCs. As it may seem, external actors appear to benefit more than the State and the people of PNG. The Jubilee Research Australia Report (2018), Callan (2013) and Tax Review Report (2015a and 2015b) also show that PNG people are not benefiting from the existing arrangement because as much benefit is going to private interests as is going to the State as dividends or taxes. Less than a quarter of the share of the pie is not only unequally distributed between the State and landowners but competed for between and among different political constituencies ${ }^{24}$. This may also affect

\footnotetext{
${ }^{24}$ While I do agree that the State does require investment either through loans or IOGCs to develop oil and gas, my assessment based on the evidence is that a better share in terms of benefits should be negotiated and
} 
development outcomes should this little share of the pie be exploited by the rent-seekers in the form of political corruption, patron-client, and rent-seeking. This suggests that both the government and developers had given limited consideration to their ethical and legal responsibilities and obligations in meeting the expectations of the landowners and people of PNG.

\section{Section 5: Independent Public Business Corporation Act 2002}

The Independent Public Business Corporation of Papua New Guinea Act (IPBC) 2002, introduced by the Somare government, established the eponymous entity, the Independent Public Business Corporation of Papua New Guinea (IPBC). This Act succeeded the Privatisation Commission established by the Mekere government in 2000. The IPBC Act provides for the Government to act for and on behalf of the State in managing all State business assets and interests due to the failure of the Privatisation Commission to achieve its mandated objectives according to the O'Neill Government (Morauta, 2011). The functions and powers of the IPBC are provided in section $8(1 \& 2)$ and section 9 (1-5)

\section{Purpose}

The purpose of the Act is provided for in 'Section 7: Objects of the Corporation.

(1) The Corporation is to act as trustee of the Trust and hold assets vested in it as trustee for the benefit of the State subject to this Act.

(2) The Corporation is to succeed to, and be vested with, assets and liabilities of the Privatisation Commission in accordance with this Act, and, without limitation, shall become trustee of any trust of which the Privatisation Commission is trustee on the succession date in place of the Privatisation Commission and subject to the terms of any such trust.

(3) The Corporation shall act as trustee of other trusts for the benefit of other persons (including trusts for the benefit of employees which may be established as part of the privatisation process under the Privatisation Act 1999) with the approval of the National Executive Council and as prescribed'.

agreed between the State and IOGCs. This is the argument I maintain on the benefit sharing arrangement throughout the thesis. 
This Act makes the IPBC the body to act for and hold assets from petroleum exploration on behalf of the Crown and yet this body is permitted to operate without guidelines or further reference to the Crown.

\section{Specific Sections Investigated}

The specific sections investigated for the purpose of this research are related to the governance aspect of managing the government's business and commercial interests. The aim is to examine the significance and implications of the Act by focusing on the Powers of IPBC, the Board and its composition, the appointment of the Board members, and independence of the Board, Trusts, and management of business interests. These sections are contained in

- Section 9 (1-5): Powers of IPBC

- Section 9A (1-2): Power of National Executive Council and Minister

- Section 10-13: Board

- Section 23: Appointment of Managing Director

- Section 31 and 32: Trusts

- Section 32-45: Finance

\section{Significance}

The IPBC Act to some extent provides that the IPBC functions independent of political interference. And this is evident in its powers, Board constitution, trusts, and finance. In so doing, it can act for and on behalf of the State to manage commercial interests by way of acquiring of and investing in assets. Not only does it do so in this respect, but also ensures that the IPBC functions effectively and efficiently in a competitive corporate world. But some instances have indicated that IPBC appears to be less independent. Therefore, this section analyses the significance and implications of the Act.

These sections are significant to the governance of energy in terms of the powers vested in the Act.

First, section 9 (1-5) provides for the powers of the IPBC in terms of its existence and functions. Additionally, section 9A (1-2) provides for the powers of the NEC to determine 
the terms and conditions of the employment of the chief executive officers of the Corporation and business enterprises and consultants of the Corporation and business enterprises. Secondly, section 10-13 provides for the Board, its roles and functions, Directors and appointment of Directors and Chairman and Deputy Chairman. Third, section 23 provides for the appointment of the Managing Director. Fourth, sections 31 and 32 provide for the Trusts and Trustee and its powers. Lastly, sections 32-45 provide for the finance and how it should be managed.

These sections have several implications.

The first of these is that the IPBC Act appears to give more powers and influence to the Minister responsible in the business and commercial interest of the State which may provide an opportunity for unethical behaviour in the governance of the corporate interest of the State. The Minister responsible decides on the appointment of the nominee of the Board through a recommendation to the National Executive Council (NEC). The NEC only acts upon the advice based on the recommendation of the Minister. Such an arrangement can allow the Minister to influence decisions of the Board and management of assets based on political interest other than national interest. It is argued that the Act allows the government, through the NEC, a limited role in influencing the decision of the entity by the design of it. The Minister appears to be the most influential player in the IPBC.

The State, through the government, has limited powers to interfere in the matters of the Board and IPBC because of the powers vested in it as a Trustee. The Trustee in this sense becomes an absolute owner of the State asset. Such powers vested in the Trustee in the absence of full transparency and public accountability may create the potential for conflict of interest, unethical and unsound-decision making by the minister and Board. This institutional arrangement by law may allow rent-seeking, political corruption, and patronclient. This was the case when the previous Minister, Hon. Arthur Somare was accused of creating such an institution (IPBC) to facilitate his political interests rather than national interests (Morauta, 2011). A good example is the controversial International Petroleum Investment Company (IPIC) loan obtained outside of the government legal process to purchase State equity in LNG project. This appears to be unethical and economically unsound. There has been a lack of transparency and accountability leading to underperformance of SoEs as a result of mismanagement and weak commercial discipline. 
Due to the increased controversy surrounding the creation and operation of IPBC such as the lack of public scrutiny on its operations and political interference on the Board, the Act was reviewed in 2012 by the O'Neill-Nama government under the leadership of Sir Mekere Morauta as the Minister for State Enterprise. The following were the key areas being proposed by an amended Bill:

- Reinstating Section 6.5 of the IPBC Act, which expressly guarantees IPBC's independence from political interference and requires IPBC to operate on sound business principles.

- Adding a new provision allowing the responsible Minister to issue directions to IPBC only after consultation with NEC and the directions being published in the National Gazette.

- Replacing Section 9A with a provision enabling NEC to directly appoint directors to Public Enterprises on the recommendation of the Minister. (At present directors are appointed by the IPBC Board, with NEC having the right to object to the IPBC Board's nominees.)

- Amending Section 29.4 to remove the IPBC Managing Director from coverage under the Salaries and Conditions Monitoring Committee Act, in line with other IPBC and Public Enterprise staff

- Amending Section 38, which at present enables IPBC to lend money to any Public Enterprise in which the State or IPBC has any level of ownership.

- Amending Section 46B, which requires majority-owned Public Enterprises to get Ministerial approval, on the recommendation of the Mana Director of IPBC, for all commitments in excess of K1 million.

- Strengthening the requirement of Public Enterprises to follow due process and for directors to comply with the law (Morauta, 2011).

These amendments were captured in the KCHL Act and KPHL Act respectively.

\section{Section 6: Petromin Act 2007}

The Petromin Holdings Limited Authorisation Act 2007 (PHLA) was legislated by the Somare government in 2007. The PHLA created a new government commercial company called the Petromin PNG Holdings Limited (PPHL). This is a revenue-generating institution operating as a commercial enterprise with an objective to efficiently manage the 
State's equity in the mining and petroleum industries for and on behalf of the people of PNG.

\section{Purpose}

The purpose of the PHLA is provided for in the Act as:

'Being an Act:

(a) to recognise the establishment of Petromin PNG Holdings Limited as a commercial enterprise and to provide that Petromin PNG Holdings Limited is not the State or an instrumentality of the State and that its assets are not public assets; and

(b) to permit the State to nominate Petromin PNG Holdings Limited as the nominee of the State to acquire certain assets for the purposes of the Mining Act 1992 and the Oil and Gas Act 1998 and for related purposes; and

(c) to authorise the State to direct Mineral Resources Development Company Limited to transfer certain assets to Petromin PNG Holdings Limited; and

(d) to authorize the State to direct Independent Public Business Corporation to transfer certain assets to Petromin PNG Holdings Limited;

(e) to make consequential amendments to certain other Acts to facilitate the application of this Act'.

Furthermore, s4 (2) provides the mandate for the company to hold State equity in mineral, oil and gas projects and develop and commercialise mineral and oil and gas interests in PNG either wholly or in partnership with other investors. The mandate is to acquire and hold all future State interests in petroleum and mineral projects both in the upstream (exploration and production) and in any value-added downstream processing projects. In so doing, it not only maximises the value through the development of mining and petroleum in PNG but also to reinvest in socially responsible projects which benefit society and make a profitable return for the shareholders.

Therefore, the PHL Act provides for the government to conduct its business operations in petroleum and mining for and on behalf of the people of PNG. 


\section{Specific Sections of Investigation}

The specific sections in the PHLA that have been investigated are those that relate to the governance aspect of managing the State's equity. The focus is on the Powers of PPHL, the Board and its composition, the appointment of the Board members, independence of the Board, Trusts, and the management of business interests. These sections are contained in s4 (1-4), s5 (1-6), s6 (1-3).

\section{Significance}

The establishment of PPHL brought into being an important State company managing equity for and on behalf of the people of PNG. For the first time in PNG's history, the Somare government created a company that would participate as a commercial entity at arm's-length from the government in the exploitation of minerals and petroleum and oil and gas development in the country. In doing so, the Act gave the State an active role in governing and managing the State's commercial (economic) interests. Before the coming of this Act, the State's interests have been managed by other companies or as a quasiindependent arm of Treasury. The coming into effect of this law allowed the transfer of assets and commercial (participating) interests from MRDC and IPBC to PPHL.

But PPHL too was seen as a controversial Company given the critical issue of governance relating to the issue of Trusteeship and Board. Therefore, it may have implications on transparency and accountability, such as conflict of interest in decision-making.

It appears that PPHL may not be independent despite operating as a commercial enterprise in many ways. First, the Act gives absolute power to the Prime Minister to act for and on behalf of the State and People of PNG as the Trustee Share Holder. This implies that the Trustee Share Holder owns PNG's share of the mining and petroleum equities or projects or the commercial interests. If that is the case, then there is no guarantee that the shares will be prudently managed and equally distributed to society and beneficiaries. The Trustee Share Holder may influence the commercial interests of the State Company for political interests.

Secondly, given the provision that the Prime Minister is the Trustee Share Holder and therefore the Chairman of the Board does not seem entirely transparent because he or she may not be accountable in the conduct of the business operations. The Act to a certain 
degree renders the Board a rubber stamp as it may be interfered with for political or personal gains by the Chairman or the Trustee Share Holder. In other words, the Act provides an opening for rent-seeking, political corruption, and patron-client relations. A good example of this type of occurrence is that in 2008 Prime Minister Grand Chief Sir Michael Somare was alleged to have failed to declare his private shareholdings while acting as the shareholder in trust for the Independent State of Papua New Guinea. This allegation was related to his private properties overseas and role as the Trustee Shareholder of Petromin (Kantha, 2008).

In addition, the Act does not seem to promote equal participation given the interest it has relative to the IGOCs. The benefits for the State and landowners are less than 50\% in both the mining and petroleum sector based on a makeup of the State and landowners' participation:

- Petroleum - State participation in projects is $22.5 \%$ while $2 \%$ is reserved for the landowners

- Mining - State participation is up to $30 \%$ while $5 \%$ reserved for the landowners.

This situation or environment created here is similar to the OGA 1998, because it did not fully capture the ethical considerations of resources development in terms of fair distribution of benefits and equal participation. First, much of the profits after tax are going out of the country while less is being unequally redistributed by the State. Second, the benefits received from a) its share of the profits as co-owner b) taxation; and c) infrastructure and services built to service the projects are relatively unfair because there is no equal participation where all parties would benefit. This implies that the Act provides fewer opportunities for equal participation and fair distribution of benefits to the landowners.

Another implication of this institutional arrangement is that the Act provides for the Prime Minister to be the sole Trustee Share Holder of these commercial interests in terms of equities and benefits for and on behalf of the State and the people. The government argued that this arrangement is the best economic option to manage commercial interests for and on behalf of the State and people of Papua New Guinea. However, this argument may have some ethical issues. First, it is more economical to have the government through the NEC to act for and on behalf of the State and citizens. That is, the NEC would collectively act in the best interest of all parties in accordance with the governance framework. This is a 
traditional function of the State in the Westminster system to ensure there are checks and balance in decision making of commercial interest. Second, having the Prime Minister to act for and on behalf of the State and citizen may have ethical issues when it comes to decision making relating to the commercial interest. It is argued that sometimes the Prime Minister may act outside of the national interest as the Trustee Shareholder. Given the prevalence of political corruption in PNG, the private interests of the Prime Minister may conflict with the national interests. This may, in turn, affect the distribution of wealth to society. While this may sound economical for the purpose of managing commercial interests for and behalf of the State and People of Papua New Guinea, on the other hand, it may also be seen as unethical because the tendency for equal distribution of wealth is less likely due to a high prevalence of corruption in the country.

The Act also allows for geopolitical influence in the government decisions given the governance structure of the Board and ownership. The Trustee Share Holder may be influenced by the competing giant energy players under the umbrella of commercial interest.

\section{Section 7: Kumul Consolidated Holdings Act 2002 Amended 2016 and Subsidiary Act Kumul Petroleum Holdings Authorisation Act 2015}

Two pieces of legislation are relevant:

\section{A. Kumul Consolidated Holdings Act 2002 Amended 2016}

The Kumul Consolidated Holdings Act 2002 Amended 2016 (KCHA) was introduced and legislated by the O'Neill government in 2016. This Act brought all commercial interests (mining and petroleum and State-owned enterprises) under a single framework. This Act abolished the IPBC and PPHL; the Act was a complete revision of the IPBC Act 2002 (previously amended in 2012). The State's interests in the institutions (State-owned enterprises) under the IPBC were transferred to KCHA with the exception of National Petroleum of PNG (NPCP) renamed as Kumul Petroleum Holdings Limited (KPHL) and mineral assets named as Kumul Minerals Holdings Limited (KMHL). These subsidiaries within $\mathrm{KCH}$ are established by the following Acts: The Kumul Minerals Holdings Limited Authorisation Act 2015; Kumul Petroleum Holdings Limited Authorisation Act 2015; and 
Kumul State Enterprise Holdings Limited Authorisation Act 2015. These changes were aimed at improving the efficiency of the different State companies.

These two Acts (KCHA and KPHLA) will be discussed together as the former creates the latter, therefore, it is more appropriate to examine them in the same context.

\section{Purpose}

The purpose of $\mathrm{KCH}$ as found in section 7 of the Act is to exercise for and on behalf of the Government, and for the benefit of the State, the trustee ownership of, overarching business management of, and provision of financial resources and services for, certain State assets, notably the coporatised entities known as the Majority State Owned Enterprises, and to act as Trustee of other certain prescribed Trusts. Generally, the Act governs the State's commercial interests in mining and petroleum and SoEs.

\section{Specific Sections to be investigated}

The specific sections in the KCHA that have been investigated are those that relate to the governance aspect of managing the State's equity in the ownership and proceeds of petroleum and gas exploration. The aim is to analyse the significance and implications of the Act by focusing on the powers of $\mathrm{KCH}$, its Board composition and appointment of the Board members (Directors), and independence of the Board, Trusts overseen by the Board, and arrangements for day-to-day management of business interests on behalf of PNG. These sections are contained in

- Part I. Preliminary: s4

- Part II. Independent Public Corporation - s6-12

- Part IV. Officers And Employees Of The Corporation: s23-29

- Part V. Trusts - s31-32

- $\quad$ Part VI. Finance - s33, 37, 38

\section{Significance}

The government sees KCHA as the best strategic direction undertaken to realign the State's commercial interests under a single well-coordinated framework to promote economic 
efficiency and rescue the underperforming SoEs. And this has been evident in the creation of three new corporate enterprises under KCHL by KCHA. It also appears that the new arrangement may have implications for the governance of liquid fuels in the context of energy security. Therefore, it is important that the significance and implications of the Act are analysed accordingly.

Firstly, the power of the Corporation to appoint members of the Board and Managing Director have been repealed in section 9 (5) and section 9A so that the National Executive Council (NEC) upon the advice of the Minister has the power to appoint them. Section 10 provides for the NEC to appoint a Chairman of the Board upon the advice of the Minister by identifying and nominating a member among the members of the Board. In addition, the NEC is not limited to appointing other members of the Board recommended by the Minister. Section 23 provides for the NEC to appoint a Managing Director upon the advice of the Minister. Section 46C provides for the NEC to appoint the Board Directors of the SoEs.

Secondly, a Trust called the Papua New Guinea General Trust is established under section 31 (1-4) where the beneficiary of the Trust is the State. Section 32 provides that the Corporation shall be the Trustee of the Trust and all money belonging to each of the Trusts shall be invested or dealt with by the Trustee. Subsection 9 of section 31 provides for the dividends to be paid directly to the SWF in accordance with the Organic Law on Sovereign Wealth Fund 2012 (OLSWF). The Corporation also has the powers to borrow and lend as stipulated under sections 37 and 38. Section 50A provides for the State to nominate Kroton as its nominee to acquire so much participating interests in the LNG project and subsection 2 of 50A also provides for the State to nominate MRDC or a wholly owned subsidiary of MRDC to hold equity benefit as granted by the State under section 167 of Oil and Gas Act 1998.

Third, the Act under section 4 prevents $\mathrm{KCH}$, the Trustee, a SoE or any other enterprises in which the Corporation, the Trust or a SoE hold any shares, property or other interests from being regulated by the Public Finance Management Act; the Public Finance Management Act does not apply to the above stated business transactions. That implies that this provision directly applies to the subsidiaries of $\mathrm{KCH}$ such as KPHL and KMHL.

The implications to this Act are threefold. Firstly, the Act allows the NEC, upon the advice of the Minister responsible for SoEs, to appoint Directors of the Board and a Managing 
Director. That is, the Act provides for the Board to advertise positions of the members of the Board and Managing Director through an independent process where a qualified candidate is selected and recommended to NEC for appointment upon the advice of the Minister. This leaves room for nepotism and non-merit-based appointments by the Executive government. Arguably, the appointment process at the corporate level is independent but at the political level where NEC is involved in decision making for the appointment remains a questionable issue, since the NEC has the power to decide who governs the Board and manages the company. For instance, the sacking of Thomas Abe as the Managing Director of the KCH by the O'Neill Government has been reported by the Media as politically motivated. Mr. Abe claimed in the media that there were experiences of governance issues relating to non-transparent recruitment and appointment processes in the Corporation (Kenneth, 2017a). The NEC defended its decision that Mr. Abe was sacked because he fraudulently increased his pay (Kenneth, 2017b). This instance suggests that NEC may sometimes unethically use its political powers to interfere with the operation of the SoE. Secondly, the Act gives the Corporation the absolute power to borrow and lend which may sometimes be contrary to the national interest.

Moreover, the Trustee of the Trust acting for and on behalf of the State may be influenced by political interest given the provision that allows for the NEC and Prime Minister as the head of NEC to involve themselves directly with the Board. This means that there is a conflict of interest in this arrangement where the Trustee is the political head of the government representing the State. In other words, the Prime Minister is legally seen as a private person acting for and on behalf of the Company if there are any arbitrary decisions concerning State's commercial interest; yet the Prime Minister by virtue of this Act is seen also to be a private person acting in the interest of the Company. A good example of this conundrum was also reported by PNGi (2017c) in that Prime Minister O'Neill's expansive network of companies, and associated business partners, has put him into situations, where his political position and private interests appear to converge in ways that prompt a range of questions. Another example reported by the media was that the NEC was seen to be politically interfering with the appointment of the Board Chairman of PNG Power Ltd (The National, 2017). Therefore, transparency and accountability may be compromised to a certain degree.

Finally, there appears to be a clear lack of financial transparency because the Act provides for $\mathrm{KCH}$ and its subsidiaries to be exempted from the Public Finance Management Act. 
The PFM Act is an important piece of legislation that regulates financial transactions and the behaviour of the Corporation and its subsidiaries so that they account for public money for which they are responsible and manage on behalf of the State through the Trustee. This is a constitutional requirement for the management of public finance. Neglect of this safeguard measure makes misuse of public funds by those responsible more likely. A good example was reported by PNGi (2017a) that the MRDC Managing Director, Augustine Mano, used the State Company in avoiding tax for his private business dealings. Therefore, transparency and accountability of $\mathrm{KCH}$ and its subsidiary companies is still in question.

\section{B. Kumul Petroleum Authorisation Act 2015}

The Kumul Petroleum Holdings Limited Authorisation Act 2015 (KPHLA) was introduced by the O'Neill government in 2015. It created what is now Kumul Petroleum Holdings Limited (KPHL). KPHL operates as a commercial entity and participates in the PNG LNG Project by managing the State's $16.57 \%$ equity in the US\$19 billion. KPHL participates in the oil and gas resources and exploration in PNG territories with an option for a $20.5 \%$ uptake in every development.

\section{Purpose}

The purpose of the Act is to establish to KPHL as the sole nominee of the State to acquire, hold and manage the State's oil and gas interests and assets in PNG and to carry on business as any other commercial entity in the oil and gas sector. The Act mandates KPHL to protect and maximize the value of PNG's petroleum assets such that it can contribute to the maximum wealth for its shareholders and the people of Papua New Guinea.

\section{Specific Sections for Investigation}

The specific sections being investigated relate to the governance of petroleum and oil and gas. The aim is to analyse the significance and implications of the Act by focusing on the powers of $\mathrm{KCH}$, Board and its composition, the appointment of the Board members (Directors), and independence of the Board, Trusts, and management of business interests. These sections are contained in: 
- Part II. Kumul Petroleum Share Trust: s4

- Part III. Kumul Petroleum Holdings: s5-13

- Part IV. Kumul Petroleum Holdings to be State Nominee

- Part VIII: Leadership

\section{Significance}

The KPHLA is an important piece of legislation governing energy, in particular, liquid fuels. The passing of this Act resulted in the creation of KPHL. The purpose of its creation shows that it is clearly intended to ensure economic efficiency in the commercial management of PNG's oil and gas interests and to participate in the development the petroleum and oil and gas industries. Several sections of the Act appear to have some wider implications needing elaboration.

Firstly, Section 4 (1-3) provides for the governance of the Share Trust. This section creates KPT as the Share Trust of KPHL in holding the share for and on behalf of the State. Secondly, sections 8, 10, 11 and 14 provide for the independence of KPHL. Section 8 (18) not only prevents the assets from IPBC to be transferred to the State but also allow the transfer of all assets parked under IPBC to be transferred to the KPT. Subsection 5 of section 8 provides for the independence of KPHL whereby it authorises KPHL to function independently of, and free from, interference or direction by the State, State Ministers or Members of the Parliament or Members of Principal or Local Level Governments or officers of the public service. Furthermore, Subsection 6 of section 8 provides for KPHL the freedom to engage in all commercial enterprises without limitation and interference or direction by the State, State Ministers or Members of the Parliament or Members of Principal or Local Level Governments or officers of the public service.

Moreover, in terms of the operation of the Board, Section 10 (1-13) provides for the Board, its composition and the appointment. Subsection 8 of section 10 provides for the members of the Board to be appointed by the KPT. Subsection 11 of section 10 effect the appointment of the Chairman of the Board by the members of the Board. In addition, section 11 (1-9) provides for the appointment of the Board, Chairman and members of the subsidiaries of KPHL by the Board of KPHL. 
The Act also provides for KPHL to be the nominee of the State. Section 14 (1-3) effect KPHL to act for and on behalf of the State as its nominee in accordance with the Oil and Gas Act 1998. That is to say that, the State, and the State Minister responsible for the Oil and Gas Act 1998 will nominate KPHL as the State nominee for petroleum and oil and gas commercial interests and projects provided under section 165 and 175A of the Oil and Gas Act 1998.

Finally, section 19 provides for the Board and Staff of KPHL to be exempted from the Leadership Code. What it means is that, unlike any other public servants, the members of the Board and staffs of the Company are not subject to this code.

These sections outlined above have some implications for the governance of energy. Firstly, there appears to be an issue relating to the Trusteeship Shareholder. The 2015 Act was amended so that the Prime Minister acts as the sole principal owner of the State's assets through what is called the Kumul Petroleum Trustee (KPT) under section 4 (1-3) of KCHA and KPT Deed provisions. This has been achieved by replacing section 175 of the OGA 1998 with a new section 175A, whereby neither the State nor the Minister has the power to act as the State nominee. In so doing, the Prime Minister becomes the Chairman of the boards of KCHA, KPHLA and KPT by virtue of his office in accordance with the provisions of the relevant Deed. In this instance, he or she acts for and on behalf of the State and People of Papua New Guinea. The Prime Minister as the principal trustee becomes the sole judge of what is in the interests of the State and the PNG people. His/her decisions are not reviewable or subject to scrutiny by the courts or parliament.

The Act also provides for the Prime Minister as the sole Trustee to seek loans internally or externally outside of the existing regulations. For example, it was reported by the media that the GoPNG had obtained a controversial loan from the Australian arm of Swiss bank UBS in 2014 to buy shares in Oil Search, a joint venture partner in PNG's biggest resources development, the \$19 billion US PNG LNG project without seeking authorisation from the Legislature (ABC, 2017). The Financial Authorisation Act governs spending and borrowing behaviour of the government. That is, it provides for the government to borrow at a certain limit. Where any spending or borrowing by the government is to occur beyond the limit set in accordance with the Act, it must be scrutinised and passed by the parliament. In this case, the media reported this did not take place under the signature of Prime Minister O'Neill (RNZ, 2016). As a result, the sacked former Treasurer under the O'Neill 
Government, the Hon. Don Polye, filed a court case against the Prime Minister on this issue (RNZ, 2016). The Ombudsman Commission also mounted an investigation and referred him to the Police Fraud Squad for investigation and prosecution (RNZ, 2017). This case was struck out by the Supreme Court due to lack of evidence in 2017 (PNGLoop, 2017). This suggests an inconclusive unethical behaviour in the first instance related to the governing process within the institutions.

The singular exercise of political power if the courts and Parliament are unable to scrutinise decisions made by the Prime Minister in his capacity as Principal Trustee may also open doors for geopolitical influence over government decisions because the Act allows for the State Minister responsible for the OGA 1998, together with the Prime Minister by virtue of his or her status under KPHLA, to nominate KPHL as its nominee to participate in commercial interests and projects. That is to say, these key State Ministers may sometimes decide which IOGCs to participate with in commercial interests or projects outside of the national interests.

The second implication is the power of the Principal Trustee to make appointments to the Board. Although the Act stipulates the independence of the Board, this may not necessarily be the case. This is because the Board Chairman is, or will be, appointed by KPT. The Prime Minister decides who sits on the Board because he/she is the Principal Chairman by virtue of his/her status as the sole Trustee for and on behalf of the State. Therefore there is a possibility that immediate political interests rather than the best interests of the State or the people of PNG might dominate decision making by the Board. Such powers of the Prime Minister could be exercised at the NEC level in the appointment process of the Board members or managing Director of SoEs.

Moreover, the potential for geopolitical influence is inevitable given the permissiveness of the Act. Since the Prime Minister as a political head or even a Minister are allowed to decide on who participates in the development of petroleum and oil and gas they are open to influences beyond the interests of the PNG State and the people of PNG. For instance, the Prime Minister can influence Board's decision on a commercial strategic partnership with an IOGC.

Finally, the KPHLA exempts the Board and staff of KPHL from the Leadership Code. This raises the question of accountability. Since the Board is acting for and on behalf of the State through the Trustee who is the political head of the government there is no guarantee that 
the Board would ensure stringent regulation of the behaviour under corporate governance. A good example was reported by PNEi (2017b) and PNGexposed Blog (2018), where the Minister for State Enterprise, William Duma and the Minister for Petroleum and Energy, Dr Fabian Pok, were suspended from ministerial duties after it was alleged they had a beneficial interest in a lucrative Manumanu land deal made with the Kumul Consolidated Holdings. However, both of them were reappointed to ministerial roles by Prime Minister O’Neill, despite not clearing their allegations. Transparency International PNG (2018) in response to this reappointment stated that the Prime Minister had made a mockery of the justice system and that his government had been unjust to the people of PNG through failure to uphold integrity and accountability.

Generally, the KPHLA and KCA appear to be less independent because the Prime Minister acts as Principal trustee he or she get to appoint other members of the Board and they are able to make decisions as board members that might not be in the best interests of the State and the people of PNG. An example of this is the appointment of Board members and Managing Director of the Corporation as stated earlier.

Both (KCHA and KPHAC) have removed the two companies from the powers and requirements of Public Finance Management Act, which is the principal legislation guarding against misuse of government or public funds. In addition, the KCH and KPHL are also exempted from the Leadership Code. This lack of openness and powers allowing scrutiny of individual and collective decisions creates opportunities for decisions that are not in the interests of the State or the PNG people. Therefore, national interest could be compromised in these legislative and institutional arrangements. The Ombudsman Commission, the Law Reform Commission, and NRI did not make any comment about the absence of the Leadership Code and Public Finance Management Act provisions. Moreover, the legislature did not adequately debate on this legislation; the majority of the legislature passed the legislation without considering the implications as seen in Hansard (Parliament of PNG, 2018). 


\section{Section 8: Unconventional Hydrocarbon Act 2015}

The Unconventional Hydrocarbon Act 2015 (UHA) was introduced and legislated by the O'Neill government in 2015 to regulate the extraction of shale gas, shale oil, tight sands, clathrates (gas hydrates), coal bed methane (CBM) in PNG.

\section{Purpose}

The purpose of the Act is defined in this statement as "Being an Act to - govern the exploration for and production of unconventional hydrocarbons in Papua New Guinea, including the offshore- area; and the grant to traditional landowners and Provincial Governments and Local-Level Governments of benefits arising from projects for the production of unconventional hydrocarbons."

Act. In effect, the Act provides power for the independent conduct of the government's oil businesses.

\section{Specific Sections for Investigation}

The specific sections of interest are related to the significance and implications of the Act by focusing on the powers of UHA, Board and its composition, the appointment of the Board members (Directors), and independence of the Board, Trusts, and management of business interests. These sections are contained in:

- Section 6: Unconventional Hydrocarbons The Property Of The State

- Section 12: Powers And Duty Of The Board

- Division 13: Rights In Respect Of Land And Property: S84-94

- Part Iv: State Equity Entitlement And Project Benefits

- Section 43-45: Development Forum, Matters Required Before Development And Development Agreement

\section{Significance}

Until 2015 the GoPNG did not have a legislation to govern unconventional hydrocarbons in PNG. The government recognised this by introducing and legislating the UHA. There 
are some implications relating to governance and energy security in the specific sections outlined above in this Act which are subjected to further analysis here

Firstly, section 6 (1) stipulates clearly that “...all unconventional hydrocarbons at or below the surface of any land area, and shall be deemed at all times to have been, the property of the State."

Section 10-12 provides for the powers of the board in accordance with the application of Part II of Oil and Gas Act 1998. The rights of landowners are recognised under section 85 and, in addition, section 90 (1-19) provides for the compensation of the landowners. Section 132 (1-4) provides for the development levies to be made payable to the concerned parties. Section 62 provides for the application of the Domestic Market Obligation (DMO) provided for under section 67 of the OGA1998.

Sections 43-49 provide for the Minister to hold and coordinate a development forum to discuss issues pertaining to the hydrocarbons before any agreement is negotiated, agreed and signed by all parties concerned. Section 137 (1-6) provides for the equity entitlement where the State has the right to acquire directly, or through a nominee, all or part of the participating interest not exceeding 22 percent in each hydrocarbon project. In addition, section 138 (1-7) provides for the State to pay equity benefits, which include royalty benefits to all parties concerned stipulated under section 139 (1-5). Sections 141-145 also provide for the sharing of benefits amongst project area landowners. Section 147 (1-7) provides for the project benefits, royalty benefits and any additional participating interests granted by the State to the landowners to be received and held in Trust by the Corporate Trustee of MRDC and section 148 (1-5) provides for the administration of the expenditure made in accordance with section 144 and 147.

These provisions have some wider implications. The first is that the ownership issue has not been changed. Under the UHA, the State has absolute right of ownership over any hydrocarbons under the land regardless of landowner rights. The second implication is that the Board may not necessarily be independent, given ministerial and NEC involvement in the Board, in certain aspects relating to decision making. The third, implication is that the Act does not allow for full participation in the commercial interest and projects where up to 22 percent is a maximum. It appears that three quarters of participation in the commercial interests and projects left for the developers may attract geopolitical competition and affect participation and distribution of benefits. While it is economically viable that the State 
needs capital investment from foreign investors to develop the industry, this may potentially lead to resentment by the landowners as has been seen and also geopolitical competition by big energy players over the remaining percentage that could affect PNG's diplomatic relations with economic partners such as the US, Australia, China and others (The Guardian, 2015). Finally, these implications have the potential to encourage behaviours such as rent-seeking, political decision making, and patron-client relationships, thereby creating tension and conflict with the wider and longer-term interests of the State and the PNG people. This is clearly established in studies conducted by the Australian Jubilee Research Institute in April 2018 (Flanagan \& Fletcher, 2018; Fletcher \& Webb, 2013).

\section{Section 9: Other Supporting Acts}

There are other key pieces of supporting legislation which are important in the governance of energy. A report by the SPC (2012) provides an overview of the Acts:

- the Electricity Supply (Government Power Stations) Act (amended in 2006) which deals with powers of the Minister for Petroleum and Energy for generation, supply and extension of electricity from power facilities built with Government funds;

- the Electricity Industry Act (2002), which specifies the functions and powers of PPL;

- the Independent Consumer and Competition Act (2000), which establishes the regulation regime for the electricity and petroleum sectors;

- the Environment Act (2000), which compels project developers to conduct detailed studies (biological, social and cultural) of the environmental implications of proposed development projects, with the findings presented to the Minister for Environment for public scrutiny and debate. The final decision on the commencement of any development project lies with the State through the National Executive Council;

- the Organic Law on Provincial Government and Local Level Government Law (1995), which grants authority to 19 provincial and 299 local governments, to manage and regulate their local electricity operations. This includes distribution and management of petroleum revenues in terms of royalties and dividends; 
- the Public Finance (Management) Act (1995) sets out rules on the State financing of electricity projects. This also includes governance of revenues in petroleum;

- the Land Act (1996), which sets out the procedures for the State to attain customary land for public purposes. This includes the State acquiring land by agreement with landowners and, under some circumstances, for the Minister for Lands to make compulsory purchase when land is required for a public purpose as defined in the Act $^{25}$;

- the Land Disputes Settlement Act (2000) sets out the legal process for the resolution of disputes involving customary land and provides for a land disputes committee to be established at local, district or provincial level to mediate grievances on land issues;

- The Lands Groups Incorporation Act (1974) was developed in recognition of the need for indigenous peoples to participate in the formal economy while at the same time protecting their customary land interests. A customary group can register with the Register of Incorporated Land Group and, once registered, the rights and liabilities of the customary group become the rights and liabilities of the Incorporated Land Group (ILG). The ILG then becomes the representative of the tribe in the formal legal system and is able to enter into agreements and make decisions on behalf of the customary group (2012, p. 29).

- Public Funds Management Regularisation Act 2018. The purpose of the Act is to deal with the hypothecation or earmarking of non-tax revenue collected by public and statutory bodies. The second is to ensure that the management and control of public funds is strengthened and to ensure that value for money is delivered in compliance with lawful processes to spend public funds. It provides for the government to manage 90 percent of the revenues from SoEs and statutory authorities (National Parliament of Papua New Guinea, 2016). That is, the Act directs all these institutions to retain 10 percent and transfer 90 percent of their profits into a Revenue Consolidated Fund Trust Account to be managed by the Department of Finance for and on behalf of the State and the GoPNG for the budgetary purpose (GoPNG, 2017).

${ }^{25}$ This Act was amended in 2018, in particular, section 62 on APPEALS (National Parliament, 2018). 
These Acts have implications that relate to some of the issues and challenges particularly electricity, environmental concerns, land ownership and distribution and management of petroleum revenues. For instance, the Electricity Acts provide for the Minister for Petroleum and Energy to generate, supply and extend electricity throughout the country. This also relates to the Minister exercising his or her powers to generate electricity from different sources including petroleum. Another example is the Environmental Act which provides for the regulation of environment in petroleum and energy sector. Moreover, the Lands Act provides the basis for land ownership in petroleum and energy sector. The last example is the latest certification of the Public Funds Management Regularisation Bill 2017 by the Parliament in 2018. This Act provides for the State the absolute right to access 90 percent of the revenues (non-taxable) generated by the SoEs (including KPHL) and statuary authorities. These funds will be parked under a single Consolidated Revenue Fund Trust Account managed by the Department of Finance for the purpose of funding the budget. There are several implications of this Act. The first is that the Act prohibits SoEs and other related institutions to challenge government decisions (not subject to any judicial and administrative review) on the management of money. While the government has the power to decide on the management of SoEs and their assets, this may have an impact on governance issues related to revenue management. In addition, it leaves no room for SoEs and other institutions to control government spending that could have an adverse impact on their operation and the economy as a whole. In other words, the government would not be held accountable for the management of this money. Moreover, it would be difficult for the SoEs to respond to other investment needs of the SoEs as they are left with only 10 percent to manage its commercial operations. The SoEs are better managers of profit (revenues) than the government. The Ombudsman Commission has challenged the constitutional validity of this Act in the courts (EMTV, 2018).

\section{Part 2. Policies}

Three policies have been selected and analysed for their relevance to the governance of energy and energy security. These three policies are PNG National Energy Policy 20162020, PNG National Security Policy 2013, and Defence White Paper 2013. 


\section{Section 1: PNG National Energy Policy 2016-2020}

The PNGEP was introduced by the O'Neill Government in 2016 to drive sustainable industrial development through the energy sector. PNG potentially has one of the richest energy sources in the region and the government has recognised the value of energy as a driver of inclusive sustainable economic growth and development.

\section{Purpose}

The purpose of PNGEP is reflected in this statement on page $\mathrm{xi}$, "The overall objective of the energy policy is to ensure affordable, competitive, sustainable and reliable supply of energy to meet national and provincial development needs at least cost, while protecting and conserving the environment."

The vision, goals and objectives of PNGEP are stated in section 1.3 as

\subsubsection{Vision}

Improve quality of life for every citizen and provide a platform for strong economic growth through sustainable development of the energy sector in line with Vision 2050.

\subsection{Goals}

The Goal of the energy policy is to ensure affordable, reliable, and accessible provision of energy in a manner that is competitive, sustainable and environmentally friendly.

The focus areas of the policy are set out as objectives for implementation to achieve the Vision 2050, DSP 2030, STaRS, and MTDP I and II goals ${ }^{26}$. These areas are social, economic, environmental and energy security.

\footnotetext{
${ }^{26}$ The government's strategic political and policy directions are aimed at creating wealth (V2050) by building a world leading petroleum industry that maximises benefits to PNG and landowners, minimises impacts on the environment and social welfare and provides PNG with energy security (DSP 2030). Achieving the goal for petroleum requires a strengthening of the State institutions responsible for policy making, administration and enforcement of regulations within the first MTDP. An important strategy is to have an efficient and effective delivery mechanism established to achieve the targets (MTDP).
} 
The PNGNEP also clearly defines energy security in the PNG context: "Energy security is all about the continuous availability of energy at all times in various forms, in sufficient quantities, and at affordable prices." This policy thereby creates the operational definition for the governance of energy (liquid fuels).

Prior to the PNGNEP there had been no national policy in properly governing the loosely coordinated sector. The O'Neill Government saw the need to harmonise the various pieces of legislation through a national policy to ensure that the government could properly govern and or regulate the sector which had been developing under various legislation since 1975 . This policy lays out how the government will effectively plan, develop and manage the abundance of energy sources to drive the economy in an efficient and sustainable way. It is aligned with the legislative reform in tandem with the Vision 2050; this involved institutional reforms to align policy, regulations and commercial operations. In so doing, it aimed to transform PNG into a globally competitive middle-income economy through industrialisation by 2050 .

\section{Specific Sections for Investigation}

Specific sections of PNGNEP that have been investigated and analysed are related to the significance and implications of the policy focusing on governance of energy, in particular, liquid fuels. These specific sections are:-

- Section 2 (2.2): Legal and Regulatory Framework

- Section 2 (2.3): Current Institutional Arrangements

- Section 3 (3.2.3): Fossil Fuels - Upstream petroleum Policies and Strategies

- Section 3 (3.3.11): Fossil Fuels - Strategies in Midstream and Downstream Petroleum

- Section 3 (3.3.4): Mid \& Downstream Natural Gas - Strategies in Mid \& Downstream Natural Gas

- Section 8: Indigenous Participation in the Energy Sector

- Section 9.4: Energy Financing Options

- Section 10: Energy Efficiency and Conservation

- Section 12: Proposed Institutional Arrangements 


\section{Significance}

The energy sector lacks proper coordination, as evidenced by the various examples of legislation and policies that have appeared since 1975. To solve this policy problem the government has introduced the PNGNEP. The policy proposes new governing institutions to be established by their own legislation. This is to ensure that institutional arrangements of the energy sector are streamlined to encourage efficiency, access, and affordability under a coherent framework to drive industrialisation and sustainable development. The Bills, once passed by parliament, will establish the Energy Authority, Petroleum Authority and Energy Regulatory Commission separate from the Department of Petroleum and Energy. The energy regulatory functions, both technical and economic, will be brought under PNG National Energy Authority. The PNG Petroleum Authority will be responsible for the petroleum regulatory functions. The DPE will be restructured to manage the midstream to downstream activities of the Petroleum sector.

There are some implications for the research question arising from this policy analysed below.

The first implication that may arise from these rearrangements is potential for conflict with the $\mathrm{KCH}$ and its subsidiary companies recently established by the government and the existing institutions. This could effectively lead to a duplication of functional responsibilities. For instance, the establishment of the Energy Authority and Petroleum Authority and Energy Regulatory Commission separate from the Department of Petroleum and Energy may conflict and duplicate roles of ICCC, PNG Power Limited, and Kumul Petroleum Holdings. It might ideally be expected that a new policy would create a welldefined and unambiguous environment, but this policy appears to fail in this regard. The tendency for sectoral politics may also affect effective coordination as functional responsibilities become duplicated in its making. It takes time for reform to be institutionally accepted by different actors with multiple interests within this space.

The second implication of the policy is that geopolitics may influence the regulation of petroleum industry. For instance, IOGCs may sometimes indirectly influence ICC to regulate competition. Since a particular IOGC may intend to dominate the industry, the strategic interaction could be quite antagonistic. In addition, domestic fuel price presents challenges to be regulated by the ICCC given the monopoly of IOGCs. The case for PUMA Energy to dominate aviation industry has been in dispute over the issue of monopoly. The 
ICCC has intervened to resolve this issue. The nature of such strategic interaction would not only affect motorists as marginal cost is passed down to the chain of consumers but also affect the government and businesses who depend heavily on imported fuels.

The third implication of the policy is that the proposed strategy of financing options per se may increase the tendency for geopolitical influence and economic risks. The government is vulnerable to geopolitical influence because as a developing country that is described as having a resource-dependent economy, the government is dependent on foreign investors to develop its energy sector. Big energy players through their IOGCs can tempt the government into agreements that aappear to align with its strategic interests. Investments are a political tool used by these big energy players to influence the host government's decisions and policies and legislation. In addition, the government can be induced by domestic economic and financial pressure to seek offshore financing incentives from financial institutions which are sometimes considered as to be a high risk due to changing market dynamics. For instance, offshore borrowing and buying stocks and shares can be a risky gamble for developing countries such as PNG. The UBS loan is a case in point where PNG suffered huge losses after controversially buying Oil-Search shares through borrowing of a substantial loan from UBS.

The last implication of the policy that may arise is that achieving sustainable development would be quite challenging for a developing country like PNG when the government is trying to balance between political and economic interest and moral interest. While achieving or working towards a sustainable environment has been a global agenda that all countries are committed to achieving, it would be quite difficult for PNG to balance moral concerns and economic imperatives because it needs petroleum energy to drive its development agenda of industrialisation. Given the fact that petroleum is a lucrative industry where political actors could be easily tempted to maximise their economic interest from the rents, it could be difficult for them to adhere to global agenda at political and policy levels. This becomes even more complicated as political actors compromise with economic actors (IOGCs) to maximise their economic interests at those levels. For example, an economic transaction between international organisations and the PNG Government may conflict with the moral transaction needed for climate change amelioration. What happens is that economic transaction involving renewable energy trade tends to motivate political and policy actors to divert the course of global funds elsewhere. And this may affect the fight against climate mitigation. In other words, global funds 
intended for financing carbon trade as a mechanism to mitigate the effects of climate change may be squandered by political and policy actors at the institutional level.

Therefore, governance of energy may have indirect effects because of the complexity politics of environment and petroleum development.

\section{Section 2: PNG National Security Policy 2013}

The PNG National Security Policy 2013 (PNGNSP) was introduced by the O'Neill government. This is the first national security policy since 1975 to address national security issues (both traditional and non-traditional security). The policy is approached from a human security perspective linking it to development.

\section{Purpose}

The PNGNSP was introduced basically to address a lack of an overarching policy framework for national security issues and challenges for an effective and well-coordinated approach. It provides a whole-of-nation framework to address these issues and strengthen national security.

The policy is linked to development by emphasising human security, in particular peoplecentred security, as fundamental to national security. The policy articulates security as critical to development; a lack of security development will affect human existence. Therefore, the policy is designed in such a way as to ensure that development is protected and secured for human existence. This strategic approach is consistent with the UN definition of comprehensive security focusing on human security based on the "freedom of want' and 'freedom of fear'.

Hence the definition of the national security summarises the purpose of this policy.

National security is the protection of our citizens, national sovereignty, democratic rights, freedoms and values, strategic assets and resources, and the wellbeing and prosperity of our nation and people. 


\section{Audience}

The policy document was prepared by the government to deal with national security issues and challenges in the country. The agencies involve in implementing this policy are identified in the policy document.

Specific sections analysed for their relevance to energy governance and energy security are

- Strategic security focus of the policy

- Definition

- National security threats priorities

\section{Significance}

The PNGNSP is an important policy document which nobly links security to development by focusing on a people-centred approach. Yet the policy does clearly state how it should deal with energy security and this has implications for the political governance of energy security in PNG.

Firstly, looking systemically from global, regional and national levels, the policy identified that, among many security issues or threats (both traditional and non-traditional), geopolitics has implications for PNG. Although the policy did not clearly state energy security as an emerging security threat in PNG, it did make clear reference to economic security relating to the unpredictable economic environment in terms of economic shocks that might affect the national economy. The implication of this is that energy security is not clearly linked to economic security and how it affects the fiscal and monetary capacity of the State through the government to deal with it. PNG is not immune to energy shocks such as the price volatility of oil and LNG. This needs to be factored into an energy security policy.

Secondly, the policy identified border control as one of the threats affecting economic security given its high vulnerability to activities such as the illegal trade of goods, guns and people to name a few, where many economic benefits have been lost in the process. However, one of the missing security issues appears to be cross-border strategic natural resources. There is a high possibility of PNG's energy resources situated along the borders of Indonesia, Solomon Islands, and Australia where disputed ownership will likely occur 
in the future. Until now, there has not been any consideration given to such a credible and proximate threat. This is a missing issue in the policy that needs to be addressed.

Thirdly, the policy identified organised crime as one of the current national threats where it involves white collar criminals networking with politicians, almost all high ranking, to squander resources and wealth in the country. Such high-level corruption is highly dangerous to energy security. As wealth is squandered and diverted out of PNG through money laundering and capital flight, national development is affected and could spark civil unrest. The case of the Bougainville crisis is a good lesson for the GoPNG (RNZ, 2015; Chandler, 2018).

Fourthly, land security has been identified by the policy as a national threat due to the complexity of policy and legislative and institutional arrangements. Since land ownership appears to be conflicting with the legal system that recognises both customary law and energy laws, this may affect petroleum and oil and gas development in PNG. This also relates to the culture of landowners (both genuine and illegitimate) demanding unnecessary compensation from the State. Tension and conflict are most likely and, therefore, this policy should clearly lay out how different arrangements should be harmonised to address this threat.

Fifth, corruption is a serious problem in PNG and it has affected development outcomes in many ways. The policy has identified this as a national security threat. While admirable noble strategies have been proposed it is a difficult area to deal with because of the complex networks of organised crime involving high-level political and economic actors. Since PNG is highly dependent on energy sources and revenues where rent-seeking is systematically prevalent, the chances of dealing with this threat successfully are not high, unless it is addressed at the political level.

Sixth, the policy has identified vital asset protection which includes energy sources. Since PNG has a weak political governance system, the potential for disruption by landowners is high as the benefits of energy resources from their land are not equally shared as result of misuse of public funds.

Finally, downstream processing, illegal resource exploitation, and business enclaves have been identified and addressed. These three threats cannot be analysed in isolation because of the complex interaction between political and economic actors with multiple interests. 
Their interaction influences development dependency syndrome where government decisions are affected in diversifying the economic base, including down-streaming of natural resources. Giant energy players will continue to exploit natural resources through the process of this vicious cycle. The consequences would be lack of strategic energy stockpiling, vulnerability to energy shocks, corruption and squandering of wealth (public money). These are all energy security issues that relate to weak political governance. If there is a lack of policy and sectoral coordination at institutional level PNG will be highly vulnerable to energy security issues and challenges because of energy.

The general implication is that the policy needs to be clearly linked to energy security and development. Political governance of energy should be identified as one of the top national security priorities, since lack of political governance of energy has negative implications for the economy and development outcomes.

\section{Section 3: Defence White Paper 2013}

\section{Purpose}

The purpose of the Defence White Paper 2013 (DWP) is to provide strategic policy directions and strategies to build PNG's Defence Force for the $21^{\text {st }}$ century. The DWP builds on from the previous policies (DWP) and PNG Vision 2050 and links to PNGNSP. In so doing, it shows how DWP contextualises and responds to energy security.

\section{Audience}

The DWP is intended for government, the private sector, donor agencies and others who are interested in PNG's national security.

\section{Significance}

The DWP focuses on four core tasking areas: 1. Defend Papua New Guinea 2. Civil Emergency Assistance 3. Nation Building 4. International Obligations. Important strategic challenges have been identified. The DWP judged that PNG sovereign borders have, 
significantly, become vulnerable to poaching of resources due to degenerated PNG Defence capabilities. These gaps in many ways have affected national development.

Energy security is captured in the DWP as part of global security. It noted that energy security would increasingly become an issue in PNG due to competition over scarce resources and that there is a need for PNGDF to contribute to energy security through its task of nation building. The DWP placed specific emphasis on the strategic importance of PNG LNG which would be affected by maritime security threats such as terrorism and pirates and overreliance on non-renewable resources. The paper stated the need to minimise these threats through its core task of nation building.

Furthermore, the DWF stated in bold that in line with the PNGNSP order of imminent threat, corruption, lack of border control and illegal poaching of resources are classified as Level 1 security threats for which PNG must prepare immediately.

All in all, the DWP stated that its strategic intent is to complement government in nation building by linking human security to national development in the $21^{\text {st }}$ century. This generally implies that building a relevant force to be responsive to nation building, hence, contributing to energy security through minimising energy shocks and maritime security challenges is strategically critical.

\section{Conclusion}

In summary, it has been shown from this chapter that PNG's commercial and corporatised approach of governing LNG energy is managed at arm's-length from the purview of parliament, Cabinet, and people with non-transparent governing processes, non-transparent accountability, and non-transparent decision-making frameworks. Moreover, it has indicated that the current legislation and policies governing energy do not seem to conform to the QEGF. The intent of the some of the policies and plans that have yet to be operationalised carries the potential to improve energy security and governance of energy security in PNG. 


\section{CHAPTER 6: IMPLEMENTATION OF LNG ENERGY GOVERNANCE FRAMEWORK}

In this chapter, an analysis of how the participants and the formal accountability reports portray the formal governance framework working in practice is laid out for examination. It also incorporates evidence which reflects upon how well the formal governance requirements, established in Chapter five, have been met. The purpose of the chapter is to establish whether there is an implementation gap between the intended and practiced governance regime and the outcomes for energy security.

Three points are worthy of note here as they have had an impact on the shape of this study. Firstly, the data collected from 20 LNG policy elites and experts, including a few landowners as described in Chapter four, were rich and a decision was made to display the nuanced richness of these findings in a narrative. Secondly, questions were based on the key themes arising from the literature review. The analysis drew out subthemes from the responses. Most participants interviewed were so concerned about the economic situation they appeared very ready to provide their frank assessments of the situation as they saw it. Thirdly, the formal governance reports analysed in this chapter point to some suggestions in terms of approaches to energy governance in PNG.

The first part of the chapter analyses the participants' responses (as in their perspectives) under five themes: Political governance of energy security; policies, legislation and institutions; management of energy security; government's response to energy security and best approaches to energy security. The specific insights about the operation of laws and institutions offered by the respondents are summarised at the end of part one.

In order to protect the identity of the participants, code numbers (see Appendix 7), are used in this chapter. In the narrative, rather than using specific numbers of responses terms such as 'a few' meaning 1-4, 'some' meaning 5-8, 'several' meaning 9-12, 'most' 13-15, and 'almost all'16-20 were used.

The second part presents an analysis of some selected formal accountability reports. The purpose of the reports is to complement the participants' perspectives. Nvivo software was used to analyse the themes and subthemes for the first part. The second part was based on content analysis of the documents without NVivo. 


\section{Part 1: Participants' Perspectives}

\section{Section 1: Political Governance of Energy Security}

\begin{tabular}{lll}
$\begin{array}{l}\text { Themes } \& \\
\text { subthemes }\end{array}$ & $\begin{array}{l}\text { No. of } \\
\text { participants }\end{array}$ & Frequency of the responses \\
\hline
\end{tabular}

Relationship between political governance and energy security

\begin{tabular}{|c|c|c|c|}
\hline \multirow[t]{2}{*}{ Relationship } & 17 & Yes & No \\
\hline & & 17 & 0 \\
\hline
\end{tabular}

Political governance of energy security

\begin{tabular}{|c|c|c|c|}
\hline $\begin{array}{l}\text { Positive } \\
\text { implications }\end{array}$ & 20 & 7 & \\
\hline \multirow{2}{*}{$\begin{array}{l}\text { Negative } \\
\text { implications }\end{array}$} & 20 & Negative & Neutral \\
\hline & & 15 & 5 \\
\hline
\end{tabular}

Table 1. Themes and subthemes and frequency of participants' responses

Participants were asked how they perceived political governance of energy security, in particular, liquid fuels in PNG. Two subthemes that emerged from the analysis are discussed below.

\section{Almost all the participants felt strongly that there is an interdependent relationship} between political governance and energy security.

When they were asked if there was any relationship between political governance and energy security as a starting point from their perspective, a common view amongst interviewees was that there is an interdependent relationship between political governance and energy security because of the way the government is making decisions on petroleum energy through policies and laws. Based on this relationship, most of the participants agreed 
with the statement that political governance of energy, in particular, LNG, had both positive and negative implications to the development and national security.

\section{Participants had mixed reactions. Most of the participants felt that the way LNG was} politically governed had more negative implications than positive implications.

When asked about the positive aspects of the political governance of LNG, some of the participants felt that the LNG had increased the fiscal capacity of the economy. One participant from a state institution commented that while the LNG had been mortgaged for loans, it also contributed to the budget and stimulated the economy. For instance, they were of the view that the outcome of the investments in infrastructures based on loans would not be seen now but in the future through higher returns (P19). This view was echoed by P11 who stated that the LNG project had brought in revenues for the national budget and impacted positively on development progress, but cautioned that good governance was necessary to maintain continuity of growth.

There was a sense of positivity amongst a few participants that LNG had changed the image of PNG in the global political economy. For instance, one participant from the academia (P17) argued that LNG had changed PNG's political and economic standing in the international community and driven the economy to an unprecedented growth rate for a decade. One participant (P14) thought that LNG had brought in international best practice in good governance and management of mega projects.

Generally, the participants were optimistic about the benefits of LNG for development and to the society if the government improves on governance.

However, there were more negative comments about LNG. When asked about the political governance of LNG, most of the participants were unanimously of the view that bad governance and mismanagement of LNG had affected development progression and national security while others remained neutral. For instance, P11 from a state institution saw parallels with the governance of the mining sector in PNG and the problems encountered there, said that there was a clear relationship between the political governance of energy and security and that a civil conflict could come about if the benefits of the landowners are not managed well. The same participant made reference to a similar situation that happened in the Panguna Copper Mine where it escalated into a decade of civil war in Bougainville. 
Another reported problem was that LNG had created opportunities for corruption and negatively contributed to the development and national security. For instance, P7 from a regulatory institution thought that political governance had some influence over energy through corruption which affected the revenues for allocation and distribution of resources. Another participant from the academia argued that LNG had become politicised and created a weak climate for the state to exploit its energy sources in order to achieve superior economic growth (P17).

Several of the participants felt that the governance of LNG had conveyed a bad image of PNG internationally. For instance, one participant from a state institution thought that poor governance of LNG had raised a negative impression or perception of PNG as a corrupt country or a failed state. Another participant argued that a resource curse similar to other resource-rich countries such as Venezuela and Nigeria had painted a negative image of PNG (P19). This participant argued that this bad impression had occurred because the government had not been transparent enough to publicly inform the country about the transaction of LNG revenues.

One critical participant (P10) from a CSO drawing on the Marxist perspective suggested that the governing behaviour of state through the government could be more akin to 'black colonisation of resources' where PNG's very own political elites appeared to have colonised the resources using the existing colonial institutions to maximise and pursue their political interests. A similar observation led P13 from a revenue-generating institution to say that governance had deteriorated in that that key institutions of state were being continuously undermined in performing their constitutional roles and duties. The same participant thought that if the government does not politically govern or manage LNG through irresponsible fiscal behaviour political and socio-economic issues would increase as a national security concern. Another participant from a revenue-generating institution thought that, if this situation continues, PNG could miss out on important investment opportunities as the country increasingly becomes less attractive due to governance issues (P3).

In summary, the findings established that there was an interdependent relationship between political governance of energy, in particular, liquid fuels and national security. What stands out in this section is that political governance had a significant impact on the economy, both positively and negatively. 
Section 2: Policies, Legislation and Institutions

\begin{tabular}{|c|c|c|c|c|}
\hline Themes \& subthemes & $\begin{array}{l}\text { No. of } \\
\text { Participants }\end{array}$ & \multicolumn{3}{|c|}{ Frequency of responses } \\
\hline \multicolumn{5}{|c|}{ Policies, legislation and institutions } \\
\hline \multirow{3}{*}{$\begin{array}{l}\text { Change of policies, } \\
\text { legislation and institutions }\end{array}$} & \multirow[t]{3}{*}{20} & \multicolumn{3}{|c|}{ Reasons for change: } \\
\hline & & Political & Economic & \\
\hline & & 14 & 6 & \\
\hline \multirow[t]{2}{*}{$\begin{array}{l}\text { Independence of governing } \\
\text { institutions }\end{array}$} & 20 & Independent & $\begin{array}{l}\text { Non- } \\
\text { independent }\end{array}$ & $\begin{array}{l}\text { Partially } \\
\text { independent }\end{array}$ \\
\hline & & 0 & 3 & 17 \\
\hline $\begin{array}{l}\text { Politics of sectoral } \\
\text { coordination }\end{array}$ & 16 & 3 & & \\
\hline \multirow[t]{2}{*}{ Weak policies and laws } & 20 & Weak & Strong & Neutral \\
\hline & & 16 & 2 & 4 \\
\hline \multirow[t]{2}{*}{ Geopolitical influence } & 17 & Yes & No & \\
\hline & & 14 & 0 & \\
\hline
\end{tabular}

Table 2. Themes and subthemes and frequency of participants' responses

Participants were asked how various policies, legislation, and institutions contributed to energy security based on their perceptions. Five main subthemes emerged from the analysis which are discussed below. There were mixed reactions amongst participants.

1. Some of the participants perceived that a change of policies, legislation and institutions was economically motivated, whilst most felt that it was politically motivated. 
Two divergent and often conflicting discourses emerged on the change of policies, legislation, and institutions. Some participants argued that there had been a frequent change of policies, laws and institutions for economic reasons, while others argued that changes were politically motivated. For instance, on the optimistic side, one participant from a revenue-generating institution argued that change in policies, laws, and reorganisations of this sector made economic sense in that it streamlined all different agencies under one umbrella for efficiency purposes (P3).

In contrast, a participant from a state institution argued that changes in policy and law and reorganisation of institutions were politically motived. That is, realignment was often done by political actors for their own self-interest rather than national interest. For instance, according to the participant, the creation of Petromin under Somare and KCHL under O’Neill government were only created for those in government.

Several participants saw the change as a way of politicising and institutionalising their interest through laws, policies, and institutions in order to continue to maximise or pursue and protect their interests in order to stay in power. For instance, a participant from a state institution stated that changes in petroleum institutions were only a political means to achieve an end in the name of development (P5).

Furthermore, the same participant stated that politicians sometimes bypassed existing legislative process to change the laws to suit their interest at the expense of a development agenda. P5 made reference to a controversial loan (UBS loan) that had been pursued in an undemocratic manner. P5 argued that when political interests override national interests, political and security institutions would be compromised, thus creating national security concerns, as had been the case so far in PNG.

One other participant from a revenue-generating institution observed that a delay in implementing important policies and laws was a national security concern. They related this to economic security in the context of energy security by saying that

There has been a delay by the O'Neill government in Oil \& Gas Act review and SWF since 2012. Had we implemented these, we would have saved a lot of money. So governance in my view has a big impact on national security (P13). 
Another participant (P14) from a state institution stated that a change in policies, laws and institutions had a political motive which could lead to the resource curse. In addition, P16 from a state institution was of the view that a change in laws, policies, and institutions, in particular, revenue-generating institutions, would lead to corruption and, therefore, a negative impact on energy security.

2. Only a few of the participants thought that the governing institutions were not independent whilst most thought that they were partially independent.

When asked about the independence of the governing institutions, almost all of the participants were unanimous in their view that, despite the creation of independent economic institutions in the petroleum energy sector, at times they had been politically interfered with for political and economic interests at the expense of the national interest. For instance, a participant from a revenue-generating institution said that politics sometimes interferes with the operation of the institutions, especially in the decisionmaking process $(\mathrm{P} 13)$.

P3 stated that while the governance of the revenue generating institution seemed to be functioning well, there were some loopholes in the governing law, which allowed the Prime Minister and Minister to interfere with the Board and its decision-making. Under these new arrangements, the Prime Minister becomes the sole trustee of the state equity, creating room for suspicion of political interference in some ways.

$$
\begin{aligned}
& \text { Prime minister is the sole shareholder in accordance } \\
& \text { with the Act. Act is clear about that but there is political } \\
& \text { interference. The CEO is politically interfered by the } \\
& \text { Board and government. Looking at good governance, } \\
& \text { board structure is very effective but the downside of it } \\
& \text { is that politics influence it in different size and shape } \\
& \text { whether you like it or not (P3). }
\end{aligned}
$$

This view was echoed by a participant from a revenue-generating institution who stated that "We have good governance mechanisms in place but still there is room for political interference because the Prime Minister is the Trustee and NEC also plays an overseer role. The government at least has some say in the board because of PM as the Chairman 
and sole trustee." (P13).

In addition, P1 from a state institution observed that that the current laws governing petroleum and energy had instead made the Prime Minister more powerful. In other words, these laws rendered to the Prime Minister the right to have a say in all revenue-generating pockets of the sector. The same participant suggested that political interference should be completely removed from these government business entities; the participant likened it to a hands-off approach quite similar to Temasek Holdings of Singapore.

Moreover, concerns were raised about the ownership and Trusteeship of the revenue generating-institutions. Two participants (P14 and P17) from academia also raised the issue of political interference by the Prime Minister as the sole trustee and Board Chairman of the revenue-generating institutions. The same participants said that transparency had become a concern and agreed with other participants that, because of this arrangement, governance had been undermined and deteriorated in quality and transparency.

Finally, a common view amongst participants was that of independence of revenuegenerating institutions. It was observed that Kumul Consolidated Holding Limited as a state company may not be fully independent due to its governance structure. The principal trustee is the Prime Minister and therefore the Board may still be influenced by the Prime Minister and Cabinet or even an individual Minister. The Prime Minister, for instance, decided who was appointed to the Board.

\section{A few of the participants were disappointed with politics of sectoral coordination which} delayed and affected energy security polices and laws.

Another reported problem was politics of sectoral coordination. In their accounts of events surrounding the absence and delay of energy policies and laws, a few of the participants raised the issue of sectoral politics and lack of sector collaboration in energy governance and security. They argued that this culture had affected the way government had understood and responded to energy security issues and challenges. For instance, one participant from a state institution declared that:

The other problem now is that due to in-house politics there is no proper working relationship with DPE. DPE is now working on energy policy excluding my department. There is lack of proper sectoral policy 
coordination so definition may vary from one

department to other (P1).

In addition, P9 said that that there was no synergy of these policies under a single framework. When asked about the delay and absence of energy policies and laws, one participant (P16) argued that due to the sectoral politics among and between institutions there had been no energy security policy developed.

The findings clearly indicated that, despite the recent development of energy policy, there had been no proper collaboration between and among the key sectors. As a result, institutions which played an active role in energy governance were not actively engaged in developing the energy security policy. The findings also showed that bureaucratic politics had affected sectoral policy coordination which resulted in the absence of an integrated energy policy and various energy security definitions across related sectors.

\section{Almost all the participants viewed the policies and laws as weak. Only a few thought} the existing policies and laws were quite strong, but the only problem was political interference.

Participants were asked about the effectiveness of the existing policies and laws governing LNG. A common view amongst participants interviewed was that some of the existing policies and laws in the petroleum and energy sector had contributed to governance issues. They argued that this had undermined development and contributed to the national security in the petroleum energy sector. One participant from a landowner association stated that the Benefit Sharing Arrangement (BSA) would not benefit them due to weak laws in the energy sector.

I must say that we didn't get any benefit at all under the
three arrangements 1. Umbrella Base Benefit Sharing
Agreement (UBSA), Umbrella Base License Agreement
(UBLA) and License Base Agreement (LBA). I believe
that the agreement will not benefit us due to weak laws
(P6).

In addition, $\mathrm{P} 7$ from a regulatory institution mentioned that ineffective policies and laws have affected their revenue-generating streams to support the national budget for development purpose. The same participant believed that these weak policies and laws had 
contributed to energy insecurity.

Finally, a participant from a state institution argued that loopholes in governance in terms of laws in the state enterprise relating to petroleum and energy had created opportunities for corruption. (P1).

In summary, the findings revealed that, unlike other participants' responses who had a positive impression of the LNG regime, some of the existing policies and laws were not effective in the governance of LNG. This had affected the fiscal capacity of the government and delayed the landowners' benefits, therefore, undermined development and contributed to energy security.

5. Most of the participants stated that geopolitical influence had affected the way the government has governed and managed LNG energy.

A recurrent theme in the interviews was a sense amongst participants that geopolitics mattered in energy security at domestic level in many ways. Big energy players were seen to be important strategic (economic) partners in the development of host countries through foreign direct investments. In PNG, a significant number of the big international players have invested in petroleum and energy sector. But the downside of it is that these big players can influence the development outcomes of PNG in many ways. Participants' observations of the geopolitical influence in PNG are drawn out here.

As has already been established in Chapter four, in essence, energy is a fundamental unit of analysis in the study of geopolitics. Geopolitics, therefore, studies how the politics of geography influence a government of a resource-rich country. Energy in this context is an important strategic asset states often feature in their domestic, foreign and strategic policies. Given the scarcity of energy sources globally, states tend to compete in order to have access and secure energy resources anywhere in the world. This can mean penetrating into another state's sovereign space either directly or indirectly. Hence, a more powerful country may in many ways influence a host country's decision-making or policy to maximise or pursue their own interests at the domestic level rather than the host country's interests. This interaction between political and economic actors with the institutions of the host country's institutions tends to contribute to energy security. In the context of PNG, a variety of views were expressed about how geopolitics had influenced government decisions and policies. 
Firstly, some participants felt that geopolitics was of strategic importance to PNG, others felt it may have negative implications. One participant from academia made a link that the LNG provided a strategic leverage in which PNG, as an emerging economy in the Pacific, could use to maximise opportunities by strengthening its geo-strategic position in the region (P17). The same participant thought that this could only be done through good governance and management and that failure to do so will result in the country gradually losing its position as an investment destination and LNG competitor and supplier. Furthermore, the same participant stated that PNG must utilise its geopolitical position as a national security asset to maximise its security both domestically and globally. The same participant argued that PNG must be able to effectively manage the geopolitical influence exerted by big energy players. For instance, she must be able to avoid backdoor deals with energy players in LNG projects. P14, however, cautioned that this political behaviour could possibly lead to corruption and tension or conflict between key players. This view was echoed by another participant from a state institution who said that kickbacks could undermine economic sovereignty and national security of PNG (P16).

Secondly, there were some negative comments that big players, especially corporate giants in the petroleum and energy sector have penetrated and influenced government's decisionmaking and policy formulation in order to maximise or pursue their interest while at the same time competing against other big players. One participant from a state institution neatly summed this up by saying:

We already have big energy players and lobby groups such as Chamber of Mines \& petroleum dominating government decisions. These include $W B$ and $A D B$. They have already engaged in data acquisition of energy potentials by funding geospatial mapping in PNG. Chinese is also competing with other big powers such as US, EU, Australia, New Zealand, etc. in renewable energy such as hydro, sola etc. NZ is involved in geothermal energy including Japan and US. Japan is really concerned about protecting her LNG shipment that is why she is playing a lot of roles in the PNG. Chamber of Mines and Petroleum are very influential lobby groups in influencing government's 
decision for commercial interest (P1).

This view was echoed by P3 in a revenue-generating institution who stated that IOGC's could exert influence over government decisions in terms of their commercial interest because of their financial capability. The same participant also stated that the existence of weak regulatory institutions and functioning of governance institutions allowed IOGCs to penetrate and influence decision-making and policy outcomes. Furthermore, P13 from a revenue-generating institution supported P3's view by stating:

Yes, geopolitics has some influence on governance in the country. Since we're a resource-dependent economy MNCs have some influence on government decisions of their commercial interests. Government listens to big companies because of money they have. We don't have the capacity. We need investors to increase our revenue through tax, so yes, geopolitics has big influence (P13).

Following on from the above, some participants stated that geopolitics could fuel corruption. They saw that occurring in the process of IOGCs pursuing their interest when penetrating and influencing government decisions. For instance, one participant from a state institution claimed that big players might bribe government officials or politicians to push their agendas in decision-making through corporate donations (P5). P11 from the same institution explained it this way:

In terms of my view on geopolitics affecting our energy security, I should say that multinational corporations (MNCs) are already here and influencing government policies and decisions. This can be seen in governmentbusiness relations of Exxon Mobile PNG. (P11).

P5 emphasised that big players are already present in PNG in the resource sectors and their presence could fuel corruption in the name of development and could potentially lead to civil war. The same participant supported this claim by making reference to the Bougainville crisis, which should not be taken lightly by the government and IOGCs. The 
same participant further supported this by providing examples of wars and conflict around the world such as in the Middle East, Africa and South America caused by geopolitics.

In their accounts of events surrounding the geopolitics of oil, a few of the participants observed that there was a possibility of foreign intervention by big countries to protect their national interests because of the absence of PNG's foreign policy, energy security policy and lack of security policy coordination. They stated that big countries whose commercial or economic interests are pursued by their IOGCs may attract foreign intervention should PNG fail to protect their investments given the ongoing landowner strikes. For instance, a participant from a state institution commenting from a planning perspective that, in terms of the implication on the Go-PNG's foreign policy, the current energy policy must be framed around the security of energy on the regional and global front (P8). This view was supported by reports from the Anti-Corruption Resource Centre Report authored by Wickberg (2013) and Hayward-Jones (2017) about how geopolitics influence extractive industries in developing countries.

It was suggested by the same participant that PNG's current foreign policy should be reviewed to capture and package aspects of energy security into the foreign policy's economic and security cooperation. P8 argued that through such an understanding, these Asian partners including APEC could work collaboratively to address terrorism and piracy and threat or possibility of war in the current LNG shipping route to these countries.

P14, an academic observer, stated that geopolitically, LNG was a catalyst of greater integration of PNG's visibility in western (US) foreign policy consideration today than in World War II because it had shifted American foreign policy perception about PNG and Melanesia.

One participant from a CSO raised an important missing policy agenda relating to the crossborder resource security with Indonesia, Solomon Islands, and Australia (P10). The same participant argued that due to the absence of policy in addressing this issue, tension and conflict is possible. The same participant made reference to the environmental pollution migrating into Indonesia and the possible discovery of resources under other land and marine borders such as Indonesia, Solomon Islands and Australia. The same participant argued that Indonesia had not been demanding PNG on pollution into their country and this could be a likely problem in the future if she supported the West Papua issue. 
A second argument related to the above made by the same participant is that there is a possibility of future tension and conflict with these neighbouring countries should a resource be found crossing the borders between them. This was a national security issue that had not been addressed by the successive governments. The same participant blamed weak governance as part of the problem in addressing these potential security issues.

The same participant also observed that weak state negotiation and corruption in project contracts could lead to conflict. According to P10, the negotiations of LNG contracts were not done in a transparent manner. P10 claimed that a weak negotiating stance had led to PNG's economic sovereignty being bought off by big energy players:

The state is weak in negotiation as they have been bought off by the companies. It seems our economic sovereignty has been sold out to foreign companies. The negotiation also did not consider multiple users of the pipeline. We must allow different or multiple companies to connect to the pipeline. This is a significant aspect that has been left out for reasons unknown. For domestic security we must allow multiple users (P10).

In addition, the same participant stated that, despite having an abundance of energy sources and export of LNG to overseas market, PNG continued to import gas from Singapore and Australia because of lack of policy direction. The same participant argued that economic benefits were lost as result of geopolitics.

Furthermore, the same participant perceived that activities in support of corporate intelligence were going on in the country through the recruitment of former government actors because big IOGCs were luring them with big money through salaries or other perks.

Finally, some participants observed a lack of corporate transparency in terms of financial reporting. For instance, P18 from a state institution opined that after over 200 shipments of LNG out of the country, Exxon Mobil had not come out publicly to inform the public of PNG, and particularly the landowners, how much earnings it made, further observing that it might raise the eyebrows of the landowners when the real monetary figures come out. The same participant also stated that if anyone in the government had the information they 
were probably holding these for reasons of commercial confidentiality or probably no one in the government even knew or had this data.

The findings indicated that geopolitical dynamics was one of the factors that affected the governance of LNG in several ways. Firstly, LNG had been used by PNG as a strategic leverage to influence certain political outcomes. Secondly, corporate giants (IOGCs) had penetrated and influenced government decisions. Thirdly, it was assumed that if the government fails to manage the landowners' issues there might be a possibility of military intervention by counties allied with the LNG investors to protect their national (economic/corporate) interest. Fourth, it was observed that IOGCs could fuel corruption. Finally, there was a lack of corporate transparency in the LNG attributed to a need for commercial confidentiality.

\section{Section 3: Management of Energy Security}

Themes \& subthemes

No. participants

Frequency of responses

Management of energy security

\begin{tabular}{|c|c|c|c|c|}
\hline \multirow{2}{*}{$\begin{array}{l}\text { Management of } L N G \\
\text { revenues }\end{array}$} & \multirow[t]{2}{*}{20} & Positive & Negative & Neutral \\
\hline & & 0 & 13 & 7 \\
\hline Transparency \& & 20 & 0 & 13 & 7 \\
\hline
\end{tabular}

Table 3. Themes and subthemes and frequency of participants' responses

Participants were asked whether the government was able to manage energy security. Three main themes emerging from the analysis are discussed below.

\section{Most of the participants thought that LNG revenues lacked prudent management}


A recurrent theme in the interviews was a mixed sense amongst participants that management of LNG revenues had contributed to the economic and financial crisis in PNG. As set out in the introduction and supported in the literature review, there has been a windfall of revenues since 2014 when the country began exporting its first LNG to the Asian markets based on a long-term arrangement. The economy was expected to experience significant exponential growth and accelerated development on the back of a decade-long impressive economic growth in the Pacific region. But since 2014, the economy has trended downwards until it faced financial and economic crisis in 2017. Although the government endorsed stability and confidence in the economy, the country seemed to have faced financial crisis according to the NRI reports (e.g. Levantis \& Osborne, 2015; Osborne, 2017). These reports deem that poor resource revenue management since 2014 could have been one of the main causes. This, in turn, has affected the fiscal and monetary regimes. This section analyses what, in the view of participants, may have contributed to this crisis.

There was a sense of disappointment amongst participants that there seemed nothing wrong with the fiscal and monetary policies governing the economy on paper, except that the way they had been governed and managed in practice appeared to be a public policy and security problem.

Firstly, in their accounts of the events surrounding the economic and financial crisis, it appeared to them that the economy had been affected by poor governance and weak management. The participants, on the whole, seemed to point to the fact that the underlying causes of the economy were poor governance and mismanagement. Whilst a few mentioned that market forces played a partial role in the economic crisis, all agreed that governance at the political level has been the biggest problem. This view was echoed by another participant in a state institution who believed that both market forces and governance affected the economy in general but governance at political level was the problem (P19).

One other participant from a state institution also supported the observation that the budget was expansionary, because it had been framed using the LNG revenues (P5). The same participant observed that the price fluctuation did not affect the LNG revenue. According to the participant, this had influenced the government in obtaining more unnecessary loans in the name of big projects interest. The participant also added that because of this, landowners had since been on strike. The participant furthermore stated that the 
government failed to implement SWF and honour the UBSA arrangement despite more than 200 shipments of LNG cargoes since 2014.

Most of the participants argued that the government may have mortgaged the LNG for high impact projects based on the ruling political party policies. A few felt that market forces had little effect on the LNG revenues. One of the participants from a state institution confirmed this by saying that the government did not have an issue with the price due to a locked-in long-term contract with the buyers.

This is largely influenced by a long-term locked-in $L N G$ contract between the government and buyers of $L N G$. That means, even if the price fluctuates in the global energy market, it will not necessarily affect the fiscal capacity of the economy. Given this commercial guarantee, the $L N G$ revenues have not been affected during the low price period, in contrary, to what the government has been stating publicly (P19).

The participant further stated that had the government borrowed loans in a manageable manner, the country would not have faced this economic and financial crisis (P19).

Apparently, according to the same participant, the government had claimed that the market price has been the problem. "On the contrary, the problem of price fluctuation should be on buyers because they obviously need money to continue purchase PNG's LNG. Instead, PNG seemed to inherit their problem" (P19). Since the government had already mortgaged the LNG revenues for huge loans, it had been compelled to borrow at an unprecedented level to sustain those policy priority areas. As a result, there had been cuts in the budget which consequently led to an increase in inflation, depletion of foreign reserves, an increased exchange rate and increased unemployment as explained by one participant from an economic perspective in a regulatory institution. Landowners' benefits were delayed and the purchasing power of the ordinary citizens was reduced to sustain the increasing inflation on basic goods and services, while business experienced a backlog of foreign reserves in doing business (P20).

In order to cushion the economy, the state companies such as KPHL were directed by the government to rescue the financial problem through an offline payment. This action 
received an overwhelming public criticism as stated by a participant from a revenuegenerating institution (P3). Another participant from a state institution also confirmed that because of the huge budget deficit, the government had no choice but to task its revenuegenerating institutions to raise tax above the existing threshold. Other corporate taxes were imposed, excluding some mineral and petroleum companies, which seemed to be preferentially unfair as asserted by yet another participant (P5).

Additionally, borrowing and spending driven by the political actors was seen as a way to impress the public in order to purchase and build political capital (votes and public confidence) according to participants' responses. One participant from a revenuegenerating institution maintained that this was done through conspicuous borrowing and spending behaviour (P13). The same participant furthermore affirmed that the government has been borrowing more to impress the public through unnecessary spending in mostly capital cities (NCD and Lae) over rural areas. As a result, this had affected the balance sheet, despite warning from experts and financial institutions (P13).

When asked about resource curse and Dutch Disease, the participants were unanimous in the view that the government management behaviour had caused signs of 'resource curse' and 'Dutch Disease'. One participant from a state institution declared that the economic crisis is a sign of 'resource curse' and 'Dutch Disease' as experienced elsewhere in other developing countries.

\section{In fact 'resource curse' is becoming obvious which may lead to 'Dutch Disease'. We don't seem to have wise investment and good management at political levels. The big challenge for energy security as I see is management (P19).}

Most of the participants agreed with the statement that the O'Neill government did not seem to perform well compared to the Somare government, despite different levels of governance and corruption issues in managing the economy. The Somare government was able to bring political and economic stability through its sound macroeconomic policies and prudent financial management for a decade with a surplus budget. The highest was an economic growth rate of about 11 percent. When asked about governance issues under Somare and O'Neill governments, the participants were unanimous in the view that corruption level had increased under both governments. They also thought that under 
O'Neill government the economy had collapsed compared to the Somare government (P16).

This view was echoed by another participant from a state institution who said that the Somare government was more transparent in terms of the transitional arrangement of petroleum and energy sector realignment than the O'Neill government. He further averred that when the Somare government was unconstitutionally overthrown by the O'Neill government, the economy began to signal a decline and proliferation of high-level corruption leading to the economic and financial crisis (P19).

The same participant argued that the O'Neill government had authorised double exemptions or tax holidays to IOGCs for exploration and cautioned that, if this practice continued, security issues would increasingly become challenging. One other participant from a landowners group believed that both governments (Somare and O'Neill) may have poorly managed the LNG money because of the way they had diverted the revenues of LNG away from PNG citizens and traditional landowners. Participants were asked which government had honoured BSA effectively. When asked about the BSA, the participants were unanimous in the view that corruption had caused unnecessary delay in their benefits. For instance, one landowner participant argued that corruption in the Somare and O'Neill governments had delayed their benefits and felt that both governments had cheated the genuine landowners by not honouring their commitment P6.

In summary, the findings show that the government had not prudently macro-managed the revenues of LNG. The most striking finding to emerge from the participants' responses is that the management of LNG revenues by the government had largely affected the fiscal budget due to a locked-in contract with the LNG buyers. Market forces, however, did play a partial role in this equation. In addition, the high windfall of LNG revenues seemed to have induced weak political governance over LNG which led to an economic crisis and delay of honouring BSA for the landowners. Moreover, the findings also showed that there were signs of 'resource curse' and 'Dutch Disease' in the economy. There was disappointment levelled against the O'Neill government in the way it governed the economy. The findings further add to the view that under the O'Neill government, tax exemptions and tax holidays were unfairly issued to IOGCs. 


\section{Most of the participants were disappointed that transparency and accountability}

aspects of the management of $L N G$ revenues had not been adequately addressed.

Concerns regarding the transparency and accountability of managing LNG were more widespread. Despite recent work done by the government to improve transparency and accountability dealings with the extractive industries, a lack of transparency and accountability in the governance and management of LNG revenues seemed to persist because of existence of relatively weak policies and laws, lack of contract transparency, lack of publication of financial reports, and lack of implementation of policy recommendations as revealed by participants' responses and supported by documents.

Transparency and accountability seemed to be a problematic governance issue in the petroleum and energy sector. Some participants agreed that many of the existing policies and laws had been manipulated in many ways so as to facilitate the interests of political and economic actors. For instance, one participant from a regulatory institution claimed that, despite some work on the extractive industries relating to PNGEITI, issues relating to revenue collection continued to be a problem (P7).

There were more negative comments on policies and laws in terms of transparency and accountability. For instance, one participant from a revenue-generating institution asserted that in the current governance structure of the Kumul Consolidated Holdings (KCHL), there would still be room for political interference because the Prime Minister is the trustee and therefore decisions of the Board may sometimes appear to be non-transparent. Since the Prime Minister is the trustee on behalf of the people, it would be quite reasonable to argue that the notion of accountability could be in question (P3). Another participant from a CSO argued that, because of this, the public had lost confidence in the government and therefore felt that the government's credibility to be at stake (P10).

Another reported problem was contract transparency. Participants argued that many of the contracts had systemic effects on development and national security. For instance, P10 from a CSO argued that some of the project contracts signed between the government and the IOGCs and government and domestic corporate clients appeared to be non-transparent because they were facilitated outside of the national interest.

A common view amongst participants was that contracts were awarded to maintain political and economic interests through the democratic process. For instance, one participant from a state institution felt that some political actors often award contracts to their own business 
(P19). The same participant elaborated that political actors often collaborated with the government actors (officials) and economic actors who were both their clients (business partners or their own subsidiary businesses). The proposal usually followed the democratic process but was often inflated for other interests other than development (P19).

Opinions differed as to whether projects awarded by the political actors to their business clients were inflated. Most of the participants agreed with the statement that some contracts often bypassed the officially established procurement and tendering process. For instance, one participant from a revenue generating institution made reference to how contracts had been inflated for mega events held recently in PNG. The FIFA World Cup, Pacific Games, and other international meetings were some of the events that attracted inflated infrastructures (P7). Furthermore, P5 argued that these nondemocratic activities or malpractices were done at a sector-wide level motivated by the windfall of LNG revenues. According to P10 from a CSO this had created a development challenge and national security concern. This view was echoed by a participant from a state institution who concluded neatly that transparency and accountability could trigger conflict should this behaviour affects landowners (P5). In light of these public criticisms on the process of contracts awarded, P7 also thought that some stories were correct while others might need verification.

When asked about the transparency of financial reporting, the participants were unanimous in the view that financial reports relating to petroleum and energy had been either distorted or kept secret by the government and IOGCs. For instance, one participant from a state institution alleged that, until now, the government had not been clear on spending of the LNG revenues (P18).

Finally, this lack of transparency theme came up, for example, in discussions of government's response to the implementation of EITI reports among others. The participants, on the whole, were of the view that the government had been inconsistent in policy implementation in relation to ensuring transparency and accountability in the petroleum and energy sector. It appeared that given the non-democratic activities, some of the key policy recommendations relating to transparency and accountability of extractive industries such as petroleum and energy were not adequately implemented. For instance, one participant from a CSO argued that some of the important recommendations contained in the PNGEITI were not implemented. 
Two most important reports in relation to governance

of extractive industries were submitted to the government for implementation. Until now none of the recommendations were implemented (P10).

In addition to this, it was also observed that the government, through the Office of the Auditor General, does not audit LNG revenues. A participant in that office confirmed that an international auditing firm by the name of PricewaterhouseCoopers (PwC PNG) had been auditing government's LNG revenues since 2014 .

It was also observed that the government had been operating in secrecy because of governance and corruption issues linked to LNG revenue. While many of the participants responded openly in the issue of management of LNG revenues based on the frustrations they held against the government, only a few responded generally. More so, there was a lack of reporting in the way revenues were managed, with the exception of PNGEITI recently. There was less reporting on the government side of the story with the public forced to rely on distorted reports in the media. Despite this, it was also observed that social media has played an important role in publishing on this issue in blogs and electronic news feeds.

In summary, the findings generally indicated that transparency and accountability was one of the biggest issues and challenges in the governance of LNG. The collection of revenues by the relevant institutions had not been effective to feed the fiscal capacity of the state. Moreover, there was political interference in the laws, policies, and institutions in governing LNG for political and economic interests other than national interests. Another interesting finding is that some of the commercial contracts between the state and IOGCs seemed to be non-transparent. It is also interesting to note that financial reports of the government including IOGCS and NOGCs were either incomplete, distorted or secretive. The government was inconsistent in policy implementation in relation to ensuring transparency and accountability in the petroleum and energy sector. 


\section{Section 4: Government's Responses to Energy Security}

\section{Themes \& subthemes No. respondents Frequency of responses}

\begin{tabular}{|llll|}
\hline \multicolumn{2}{|l}{ Government's response to energy security } & \\
& 17 & Positive & Negative \\
\cline { 3 - 4 } & & 1 & 16 \\
\hline Policy and legislation & 20 & Adequately & Inadequately \\
\cline { 3 - 4 } & & 6 & 14 \\
\hline Military and security & 3 & Adequately & Inadequately \\
\cline { 3 - 4 } & & 2 & 17 \\
\hline
\end{tabular}

Table 4. Themes and subthemes and frequency of participants' responses

Participants were asked about government's responses to energy security issues in PNG based on their experiences, observations, and perceptions. Three themes emerged are discussed.

\section{Almost all the participants were disappointed with the Benefit Sharing Arrangement} (BSA).

Participants generally were of the view that the government is not doing enough to respond to energy governance and energy security issues in PNG. For instance, one participant (P16) from a state institution said explicitly that this was an ongoing challenge faced by the government.

Participants claimed that the BSA is an important mechanism through which benefits to landowners are governed and managed. However, it appeared that since 1992 the government had not honoured its commitment by responding to their demands. P1 claimed that the government had continually failed in their commitment towards landowners due to unwise spending on loans to repay debt. This was supported by P5's statement that "the 
government has failed to honour its commitment under the UBSA to deliver landowners benefits, simply because they have misused the money". The money was believed to have been used to pay government debts, fund private investments and to fund politicians' elections so that they could continue to hold on to power and benefit more from the booming LNG. When asked whether the revenue-generating institutions pay royalties and dividends to landowners, P3 asserted that they do not have such powers under their respective Acts to pay landowners and could only provide assistance where necessary. "There is no legislation for KPHL to give extra as demanded by landowners", according to P3. P11 also alleged that the government, including the IOGCs and NOGC, did little to ensure spin-off benefits are provided to the landowners' demands. P16 maintained that, because of the failure of the government, IOGCs and NOGCs to conduct a proper social mapping to identify legitimate landowners, their rightful benefits were delayed.

However, only one participant (P13) from the revenue-generating institution argued that the government gave a lot of money to the landowners, but many of them spent it unwisely on immoral social activities. According to the same participant, those that spend their money wisely did not seem to make demands as often compared to the others.

In summary, the findings clearly showed that the government failed to honour the BSA from the time of its inception. This appears due to a number of related factors. Firstly, the participants thought that the money earmarked for the landowners was used by the government to pay its debts from borrowing, fund private investments and fund politicians' elections. Secondly, the government including the, IOGCs and NOGCs, did not provide sufficient spin-off benefits to the landowners. Third, the government did not conduct an accurate landowner social mapping. One further surprising finding was that KPHL did not have any provision within its legislation to deal with the landowner issues other than investment.

\section{Most of the participants thought that the government had not responded adequately to} energy security through policy and legislation, whilst only a few thought that the government had taken steps to address this policy issue.

Participants spoke of the government's responses to energy governance issues relating to policies and legislation. For instance, one participant (P3) from a revenue-generating institution insisted that the establishment of Petromin under the Somare government and reorganisation of Petromin under a single umbrella by the O'Neill government was an 
important intervention to respond to energy security issues. The second participant (P8) from a state institution argued that the government had made no attempt to look into the security of energy supply through policy intervention to deal with domestic or international energy crises. P8 made a case for PNG's shipment of LNG to Asian markets to be critically looked into due to maritime security issues that may affect the revenue and fiscal budget of the economy.

The other participants pointed directly to energy security as an issue, in terms of electricity in the context of energy poverty. Given the fact that about 70 percent of PNG lacks electricity, the government had been incrementally working with the international partners to respond to energy poverty by way of policies and legislation (P9). For instance, $\mathrm{P} 9$ from a state institution reasoned that the government was working in collaboration with WB and ADB to address these governance issues. However, the same participant claimed that
Despite this, I think the government has not really captured energy security because of lack of sectoral policy coordination. In terms of gas, we can't tap into energy as yet due to absence of Content Policy and DMO (Domestic Market Obligation) policy to address energy security issues. In think the gas policy is still in progress the question is how to link it with energy security. There is no synergy of these policies under a single framework (P9).

Another participant (P12), had deduced that the target of government is to achieve a 100 percent supply of electricity by 2050 in line with the Vision 2050 goal. The same participant said that the big challenge in that goal is that PNG power is still using oil and struggling to meet the demand, which has been the main reason for frequent power blackouts. According to the same participant, the government had not addressed domestic needs for development at the moment. Even the resource sites were not really seeing the benefits of electricity through LNG.

A further participant (P7) claimed that the establishment of SWF was slow despite much work being done. Secondly, P10 claimed that the government did not respond well to implement some of the recommendations contained in the PNGEITI report. 
In summary, the findings generally indicated that, despite the ongoing issue of electricity in the country, the government had responded to the energy security in an incremental and piecemeal manner by working with the development partners. It was also noted that the government was slow in the establishment of SWF despite extensive work done.

\section{Participants had mixed reactions on the military and security aspects of the LNG.} Many of the participants were of the view that the government had inadequately invested in the military to ensure the security of $L N G$ is guaranteed. Only a few thought the $L N G$ security was guaranteed but needed more support from the government.

Participants were of the view that the government had been protecting the strategic assets such as LNG through the existing military arrangements. For instance, P18 clearly outlined the two main tasks through the PNG Defence Force which are as follows:

a) Protection of vital assets: Major LNG or oil plants and pipelines are vital assets and though privately owned they contribute to the economy of the country. There are also energy resource plants and pipelines and their security is important for our energy exports. Parliament can call out soldiers to protect such assets in times of crisis.

b) Protection of Sea Lines of Communications: In contributing to our International Obligations; part of our job is keep our SLOCs open for shipping to traverse through our waters. Those are tasks for the PNGDF Maritime Element where we do not have to go abroad but do these within our waters to ensure they are no threats to our SLOCs. We are also obliged under the UNCLOS to do so.

Another participant (P11) supported P18 by saying that the security of LNG is guaranteed because the government has learnt from the Bougainville crisis. A reference was made to government's quick response to landowner strikes in the Southern Highlands province where the LNG production plant was located.

However, another participant (P8) believed that the government has not looked into the security of energy supply. P8 thought that if the government does not address this policy 
problem there is a high possibility of civil war, as was the case in Bougainville crisis. P8 persuasively argued the case that there were two main possible energy security threats that National Planning had not considered seriously: security of supply relating to maritime security in terms of protecting LNG shipment to the Asian markets and civil war posed by disgruntled landowners. The participant predicted that civil war is likely if the government fails to honour their promised royalties and other benefits.

Participant P10 also thought that the government had not addressed the issues of border security relating resource security. For instance, the same participant inferred that crossborder resource security such as maritime resource security and land resources security had not been considered as a national security policy.

In a nutshell, there is no national security policy addressing cross-border security issues or concerns. Example, if $L N G$ is found along the border it is obviously a national security. We have to know what Australia and Indonesia think about reserve benefits along the border as a national security concern and prepare for future implications (P10).

In summary, the findings indicated that majority of the respondents perceived that the government had not responded adequately to energy security issues in PNG, despite it being highly vulnerable to energy security threats. A few participants noted that maritime security including cross-border resource security was not well captured in the policy mix.

Section 5: Best Approaches to Energy Security

Themes \& subthemes

No. participants

Frequency of responses

\begin{tabular}{|lcc|}
\hline Political reforms & 20 & 20 \\
\hline $\begin{array}{l}\text { Policies, Legislation and } \\
\text { Institutions }\end{array}$ & 20 & 20 \\
\hline BSA & 20 & 20 \\
\hline
\end{tabular}




\begin{tabular}{|lll|}
\hline $\begin{array}{l}\text { Capacity and Capability } \\
\text { Development }\end{array}$ & 9 \\
\hline $\begin{array}{l}\text { Management of LNG } \\
\text { Revenues }\end{array}$ & 20 & 20 \\
\hline Down-stream processing & 17 & 15 \\
\hline Strategic stockpiling & 17 & 5 \\
\hline
\end{tabular}

Table 5. Themes and subthemes and frequency of participants' responses

The participants were asked what they would like to suggest to improve energy security in PNG. In response to this question, seven important strategic approaches in terms of operational and adaptive quality governance were proposed, namely political reforms; policies, legislation, and institutions; benefit sharing arrangement (BSA); capability and capacity development; management of revenues; down-streaming of energy sources and strategic stockpiling.

\section{Almost all the participants saw political governance as a major problem and suggested radical political reforms are needed.}

A recurrent theme in the interviews was a sense amongst interviewees that political reform is necessary. This is consistent with some research reports (e.g. Cohil, 2017 and Hassall, 2011). It was suggested that the underlying problem with energy governance in relation to energy security is a lack of vibrant political will at the higher levels of the government system. Politics has affected governance in the resource sector, in particular, petroleum and energy given the mega LNG project. Since the problem lies at the heart of decision-making, one participant (P1) from a state institution said that there was a need to have strong and vibrant ministers at the political level who could push for strong laws and policies to regulate the sector.

In addition, participants also observed that ethical political actors and political parties with smart policies are important elements of good governance in the energy sector. The energy 
sector is an important strategic economic asset of PNG to drive development in line with the Vision 2050. Therefore, one participant (P16) from a state institution said that if there are no right political leaders the country would face similar problems. The same participant suggested that there is a need to have good political parties to drive this agenda. The same participant added that these parties should focus more on resource sector and talk about the sensitivity of the resources and how to stabilise the economy when there is an energy crisis.

A participant (P1) from a state institution also emphasised the need for good ethical people by saying there is a need to have strong and vibrant ministers at the political level who could push for strong laws and policies to regulate the sector.

2. Almost all the participants suggested the strengthening of and compliance with existing policies, legislation and institutions to enhance energy security.

There were some suggestions that policies, laws, and institutions should be reformed. Some reports recommended for this reform (e.g. NRGI, 2017; ANZ, 2013; PNGEITI, 2013, 2014, 2015, 2016; PNGNSP, 2013; DWP, 2013; NRI Report edited Odhuno, 2014; PNG Tax Review Committee, 2015a, 2015b). Almost all of the participants argued that there is a need for strengthening some policies, legislation and institutions in the petroleum energy sector, while others were of the view that this must start with political leadership. A participant's comment illustrates this, “We have very good strong laws, policies and system but the problem seems to lie with the politicians at political level. Political institutions must be reformed". (P19). One participant (P13) from a revenue-generating institution commented that there must be increased political will and commitment from our politicians because they are legislators or lawmakers. The same participant argued that any law in relation to natural resource governance must be made with the nation's interests at the forefront. The same participant was of the strong view that that only when politicisation of state institutions stops, so would corruption too. Another participant (P3), when asked about policy, legislation and institutional reform questioned whether political interference from revenue-generating institutions should be removed to allow for transparency and accountability.

Most of the participants alluded to the notion of managing a war over resources. For example, a participant from a CSO stated that "a resource rent policy will help us define it clearly in terms of benefits. And this policy must be tied to law so that corruption is minimised. If not, it may lead to tension between landowners and state and foreign 
companies which may lead to conflict as we've experienced in Bougainville”. (P10). It was suggested that there must be good policies to manage resource rents in order to avoid future conflicts (P10).

One participant (P11) from a state institution furthermore commented that there is a need to review PNG's national security policy and tie it to energy security in order to address emerging security issues related to energy (LNG). The same participant thought that the national security policy needs a review due to new emerging security issues such as gun smuggling which is dangerous for LNG if it ends up in the hands of landowners. The same participant also felt that energy security was not clearly delineated in the national security policy. They further commented that, similarly, the Defence White Paper did not feature energy security as part of maritime security in terms of shipment of LNG across the international shipping lane to Asian markets.

This view was echoed by another participant (P16) who said there is a need for the government develop an energy security policy and align with the PNGNSP, DWP, trade policy, foreign policy and SME (small medium enterprise policy). The same participant added that there is also the need to have an energy security policy to effect regulatory change in the petroleum energy sector. Commenting on security policy, one of the participants (P10) said, in anticipation of future conflict related to resources, border security must be given consideration. One individual firmly contended that given less economic diversification, the government must look into vigorously promoting exports in every facet as much as possible to balance that shortfall (P7). And another commented that in the process, government should also promote local manufacturing industries in order to avoid economic shocks or surprises that might contribute to energy security (P20).

There were some suggestions that the SWF and the PNGEITI should be promoted by the government to ensure savings for future generations and transparency and accountability in the petroleum and energy sector. Talking about this issue P11, from a state institution, said that SWF had been established but these needed to come into effect. Another participant, when asked about the reform suggested that PNG should promptly set the SWF for energy funds to be kept and invested (P20). A few of the participants felt that the government should actively commit to the work of PNGEITI. As one participant from a CSO put it "Recommendations of the PNGEITI reports must be implemented by respective sectors" (P10). One participant commented that this would ensure good governance in the 
sector, "The Extractive Industry Transparency Initiative (EITI) is one such initiative aimed at safeguarding the interests of all stakeholders involved in the extractive industry in the most transparent and accountable manner" (P13).

Participants also suggested that there is a need to establish an independent anti-corruption institution to combat high-level corruption. Corruption has been found to have affected development outcomes and weaken governance institutions in a systematic and systemic way and that a new institution of such nature should be established to deal with this issue. Talking about this issue, one participant (P13) from a revenue-generating institution suggested the need to set up authorities like MRA or more like private sector organisations. According to the same participant, K2 million had been set aside to establish a petroleum authority to regulate the industry for and on behalf of the government and the people of PNG and, if established, it would play a critical checks and balances role. One individual suggested that the Independent Commission Against Corruption (ICAC) Bill must be passed so that it is institutionalised to investigate and prosecute corrupt leaders. And another claimed that the current government was too slow to pass the Bill and that this must be addressed urgently at the political level (P5).

\section{Almost all the participants suggested the review of BSA in order to avoid civil war.}

Concerns were raised about the BSA and the need to make it work better. The PNGHDR (2014) also recommended this review. It was suggested that that government must honour its commitment. As one participant put it, "They must be given a lot of opportunities to do small scale business or participate in big investments" (P11). One participant from a state institution commented that direct ignorance of government had affected the citizens. P5 felt that this often leads to disharmony and therefore a law and order problem as a national security issue. The same participant suggested that, in order to address this problem, the government must allow inclusive participation in energy governance of LNG projects.

One participant from a landowners' group, in response to BSA, said that the vetting process and social mapping of legitimate landowners was a problem and must be addressed (P6). The same participant suggested a strategy whereby the government must redo the clan vetting and social mapping and gazette it. 
Participants thought that that the best strategy to avoid conflict with the landowners as experienced in Bougainville is to pay their delayed benefits. As P10 from a CSO suggested, the landowners' delayed benefits must be paid to avoid conflict.

\section{Almost all the participants suggested improving and modernising the capacity and capability development of petroleum energy sector.}

Almost all the participants raised the issue of lack of capacity and capability development in the petroleum and energy sector. This view is shared by PNG Tax Review Committee (2015a, 2015b; NRI Reported edited Odhuno, 2014). The government is putting less emphasis in developing qualified human resources in different specialised areas and also boosting technological advancement. This is one of the problems in the sector that needs to be addressed. For instance, one participant in a revenue-generating institution suggested that there is an urgent need to attract qualified people to work in this multi-billion kina industry (P13). The second participant from a state institution furthermore considered that there is a need to reform the public sector and recruit highly specialised people in the sector (P16).

\section{Almost all the participants suggested the prudent management of $L N G$ revenues by} way of good governance.

Participants raised some suggestions as to how revenues from the LNG should be managed in a more transparent and accountable way. The NRI Reports suggested this reform (e.g. Osborne, 2015; Voigt-Graf, 2015; ANZ, 2013; PNGNSP, 2013; DWP, 2013). Firstly, some participants suggested that, for the LNG revenues to be governed and managed properly, political interference should be avoided. For instance, one participant from a revenuegenerating institution suggested complete removal of political interference on governing institutions (P3).

Secondly, contracts were found to be in many ways not transparent. The way these were negotiated and agreed upon without a wider stakeholder consultation was a problem. Ensuring transparency in this process of contracts would ensure good governance. Therefore, P10 from a CSO suggested the need to ensure contract transparency (P10).

Third, it appeared clear in the participants' responses that, since LNG revenues had induced political actors to behave rationally by diverting the money elsewhere for political and economic interests other than national interest, some sense of fiscal discipline need to be 
established. For instance, P11 from a state institution suggested that the government should avoid the mortgaging of LNG be getting loans to safeguard the future and economic shocks.

Finally, given the management problem at political and policy levels in the country, P16 from a state institution suggested that an effective management culture must be promoted. That is, simply, according to P19 from a state institution, ensuring that revenues gained from LNG are invested wisely and bolstered by good management.

\section{Almost all the participants suggested that PNG should promote down-streaming of} energy sources to mitigate energy security crisis.

Participants also claimed that due to lack of government's focus on down-streaming of petroleum and energy sources such as LNG, economic benefits were not translated into tangible development outputs and outcomes. The PNGHDR (2014) also supported this view. This gave opportunities for internal and external forces to exploit the resources and value in the value chain and therefore a need to have energy resources processed domestically to feed domestic and global demands. For instance, P11 from a state institution emphasised the need for PNG to have an in-country pipeline. The same participant argued that Gulf Papua LNG should be in-built for PNG's benefits. In addition to that, the country had been exporting the LNG through IOGCs and in return imported high volume of it in a secondary form to feed domestic demand. One participant from a regulatory institution suggested that a PNG entity on behalf of the state should buy crude gas from the developer, process it and sell it to buyers offshore. P20. In that way, domestic demands such as electricity issues in the country would be addressed.

\section{Some of the participants suggested the government should seriously consider stockpiling of energy to withstand energy crisis.}

Participants were critical of energy security relating to economic security caused by energy shocks or oil peak. Some research reports also recommended this reform (e.g. Kobayash, 2015; Yergin, 2006). Given the complex changing environment producing uncertainty, the need to save or stocktake LNG reserve is necessary. For instance, P3 from a revenuegenerating institution commented that, given PNG's energy poverty where about 70 percent of the population lacked access to electricity and suffered sudden power blackouts in the cities, the need to have a strategic stockpile is important. In addition, P7 from a regulatory institution neatly summarised the need to have a strategic stockpile during energy security crises as an economic security package. 
Economic security is important in particular in energy and resource sector. We don't have pools of resources stockpiled for future use during crisis. All we have are export. If there is a depression we should have some fall back strategy, example SWF must be in place, need to have oil and gas reserve for at least 8 months, in that we will not need to import because of reserve/stockpile. We also need to have more downstream processing plants in the country in order to cushion energy crisis to sustain the economy. If these measures are not in place national security, economic security and energy security will be affected. Example, there'll be currency depreciation where value of our kina will drop thus affecting our reserve. Having reserves will help sustain the currency because we have the cover, example foreign reserves or we can use the money from SWF to buy energy from depressed countries (P7).

The same participant suggested that PNG should have some stakes in energy extraction to be used for local consumption, what he referred to as strategic stockpile, in order to minimise the high cost of energy use in the long run.

In general, the findings suggest strongly that the government should consider the introduction of strategic policy interventions to address growing energy security issues related to the governance of LNG. The areas listed above are critical to enhance energy security in PNG. 


\section{Summary of Participants' Responses}

In this part, we saw that institutions, policies, and legislation, mandated by the State to govern LNG energy for and on behalf of the people of Papua New Guinea, had been interfered with by the ruling government for political interest, without due consideration of the ethical and legal responsibilities and obligations. This has been done under the guise of economic efficiency. Moreover, we saw that lack of capacity and capability of the governing institutions and sectoral policy coordination, compounded with politics bargaining for power between related governing institutions, had affected the regulation of LNG energy. We also saw that lack of policy reform at the legislative level postindependence had contributed to political interference in the operation of governing institutions. Legislation regarding ownership resources such as LNG is not well aligned with the expectations created by the Constitution at the time of independence. This misalignment has weakened the energy regime and made it less transparent and accountable to the people of Papua New Guinea.

If we take those three key points together, then this appears to indicate that despite the existence of an energy governance regime, compliance with policies and legislation by policy and political actors, including economic actors, was a major problem that affected the way LNG energy was governed and managed at the political and policy levels. As a result, it has incrementally weakened the effectiveness of energy governance and contributed to issues such as poor management of LNG revenues and unpredictable changes in policies and legislation without proper public scrutiny. This, in turn, has generated energy insecurity in PNG. 


\section{Conclusion}

Taken together, these results provide important insights into understanding how LNG was governed. It can be established that from the perceptions of participants, supported by documentary analysis, that energy security had been a national security issue since 1990s. The participants' responses and reports showed that there were both positive and negative aspects of the implementation of energy governance in PNG. In terms of positive aspects, the LNG had brought some benefits related to employment, infrastructure, revenues and others. On the hand, the LNG had negatively induced weak governance and management of the revenues. The policies and laws governing the LNG had been manipulated at institutional level by both the economic and political actors. This also included geopolitical influence by external actors over government's decisions. This clearly shows that compliance with the governing laws of petroleum energy remains a major problem and challenge in PNG.

The tax system in PNG remains, as yet, incompatible with the changing social, economic and technological challenges which, to some extent, had affected the government's ability to effectively and efficiently generate and redistribute revenues from LNG to the wider society in a transparent and accountable way.

Moreover, governmental responses to managing energy security issues seemed of a more piecemeal nature. The reports also clearly showed that the government had not been proactive in implementing many of the key recommendations provided by the policy think tanks. When combined, these factors seem largely to have contributed to the economic and fiscal crisis in 2015-2017.

Therefore, the weak implementation of the energy governance framework has had a major policy implication for national security; it has generated energy security. Some of the best approaches in managing energy security issues and challenges suggested by the participants, and supported by reports, include political reforms; policies, legislation and institutions; BSA; capacity and capability building; management of revenues; downstreaming of energy sources and strategic stockpiling in order to enhance energy security. 


\section{CHAPTER 7: THE CONTRIBUTION OF POLITICAL GOVERNANCE OF LIQUID FUELS TO ENERGY SECURITY IN PNG: A SYNTHESIS}

The objective of this research was to understand how energy governance contributes to energy security in PNG. To achieve this objective a number of supporting questions were identified in chapter one: How does governance of energy at institutional level contribute to energy security in PNG? How has energy security been managed? Have any actions been particularly successful in achieving energy security? How might we improve governance of energy in terms of decision-making, policy-making and regulatory (legal) aspects of energy security?

This chapter begins to answer these questions by drawing on the analysis presented in chapters five and six. It uses the QEGF described in chapter two as an analytical framework to unpack the constituents of the quality of energy governance in PNG under each of the dimensions of quality in that framework one by one.

The findings of this study show clearly that political governance of energy, in particular, LNG energy has had a significant relationship with national security and development outcomes. In essence, the gaps between the practices of governance explored in chapter six and the QEGF demonstrate that the present energy governance regime in PNG has resulted in energy insecurity, which, in turn, affects development outcomes as discussed below.

The QEGF, as explained in chapter two, has four dimensions, which cover a range of measurable qualities of governance: 1) enabling environment, 2) revenue management, 3) value realisation and 4) security. In respect of the research questions set out at the beginning of this thesis, the critical qualities within these four dimensions are used in this chapter as a framework to synthesise the findings presented in chapters five and six and explain how political governance of liquid fuels might contribute to energy security in PNG. The chapter ends with a summary of the gap between practice in each of these areas of quality characteristics and what might be done to improve the situation in PNG. 


\section{Part 1: Enabling Environment}

However, in order to attract these investors, countries will need to create an enabling environment that provides secure ownership rights, is subject to the rule of law, fosters transparency, and enables reasonable risk mitigation. In addition, individual sectors will have to be viewed as financially and commercially viable. This will be particularly critical in those sectors, such as electricity and heat that are largely dependent on their domestic markets. World Bank, 2010.

The World Bank (2010) statement above underscores the significance of countries having an enabling environment, critical to the attraction of foreign investments. Fundamental principles such as ownership rights and the rule of law ensure transparency and accountability in the governance of energy and security. Now, not only does this statement apply to foreign investment but, more importantly to the political stability necessary for inclusive sustainable economic growth and development. Hence, this statement has influenced the framing of the discussion to follow.

In chapters one, three, and five we saw the building blocks of the legislative and policy environment that government created for LNG. They involved the introduction of new policies and laws and the reorganisation of institutions to govern LNG in the petroleum and energy sector. The findings of the study indicate that the government created a set of institutions that should have provided an appropriate enabling and constraining environment for the governance of LNG. However, in practice, they have proven to be enabling in ways that have subverted their purpose and enabled some bad governance as a result.

Arguably, chapter five clearly showed that the policy regime governing the sector was based on Anglo-Australian law, adopted and adapted from the Australian Colonial Administration. Since 1975, the petroleum law was part of the mining law until 1998 when the Oil and Gas Act was introduced and passed in Parliament under the Mekere government. This law affected the emergence of the new institutions and rules governing petroleum and energy. A good example of this was the separation of Department of 
Petroleum and Energy from the Department of Mining. We also saw that between 2002 and 2017 both the Somare and O'Neill governments further introduced and rearranged policies, legislation and governing institutions under the guise of economic efficiency. That is, Somare introduced Petromin, IPBC and NPCP and other subsidiary institutions to manage particular aspects of the developing oil and gas industries. However, under the O'Neill government, these arrangements were reorganised and subject to new governance arrangements, whereby all former institutions were subsumed into an entity called Kumul Consolidated Holdings Limited (KCHL). Kumul Petroleum Holdings Limited (KPHL) was established as a subsidiary entity of KCHL. By way of contrast, we also saw that MRDC, an entity of mining sector created by the Mining Act, was not treated this way and continues to manage dividends and royalties of LNG beneficiaries.

Part one of chapter five also presented other legislation and amendments made as part of the O'Neill reforms which included the Hydrocarbon Act, Constitutional Amendment number 44 and the Sovereign Wealth Fund. Significant evidence revealed that these amendments were done in such a way as to give more powers to the State and governing actors. Part two of chapter five analysed the PNG National Energy Policy, introduced in 2016 and approved in 2018. This policy-legislation platform was complemented by other policies and legislation such as national security policies (PNGSP and DWP); electricity laws; environmental laws; taxation law; lands laws and customary laws as discussed in section nine of chapter five.

The evidence presented in the preceding chapter seems to suggest that, despite these legislative and policy efforts, the LNG energy governance regime remained ineffective and quite unstable, failing to produce an optimal public value. For instance, in chapter five we learnt that the LNG legislation under both the Somare and O'Neill governments lacked public scrutiny. Another relevant example was the continuous rearrangement of the policies-legislative and governing institutions by the ruling governments for political reasons under the guise of economic efficiency, again confirmed by participants' responses in chapter six. The characteristics of the quality energy governance framework discussed in turn below, allow us to probe more deeply into the data presented to understand the origins of this ineffectiveness and instability. 


\section{A. Voice and Accountability}

Voice and accountability is a critical indicator of political governance in a Westminster system of government. This involves the government providing a democratic platform on which citizens can actively participate in any form of development by presenting their perspectives on issues of interest and hold the government to account for what they do as their custodian.

In assessing this indicator in the energy sector, taking into account the broader context of the enabling environment, the findings of this study indicate that transparency and accountability was one of the biggest issues and challenges in the governance of LNG.

\section{Political interference in the policies and laws}

Firstly, the findings show that there was political interference in the laws, policies and institutions in governing LNG that enabled political interests rather than national interests. In chapter three we learnt that the government stated clearly that the policy reforms in energy governance presented in chapter five were for the purpose of ensuring economic efficiency and independence from political interference; however, governance documents in chapter five and governance reports and the practitioners' perspective in chapter six painted a different picture of how energy is governed at the institutional level. Sector participants interviewed collectively argued that there seems to be a lack of independence in the operation of the governing institutions such as KPHL due to political interference. Despite the fact that these institutions were intended to function independently of political interference by the operation of their legislation, there is no guarantee that the decisions made by them would be independent or in the best interests of the country, given the lack of public reporting and scrutiny of their decisions. It is also surprising to note that the KCHL and KPHL legislation safeguards the Trustee Shareholder, Board Chairman and members of the Board from being held accountable to the government and the public through the Leadership Code and Public Financial Management Act. As State entities, the members should be subject to the Leadership Code and public scrutiny. In chapters five and six, an analysis of the governance documents and the views of practitioners of energy governance demonstrated that LNG legislation does not allow for public scrutiny. For instance, both KCHL and KPHL are not subject to the Leadership Code and Public Finance Management Act. In other words, KCHL and its subsidiaries are outside of the purview of the accountability institutions, in this case, the Ombudsman Commission. In addition, the NRI report on SWF implications was not taken into consideration by the government. 
These implications were found across all legislation in chapter five. These findings are in accord with recent studies indicating that corporate governance of SoEs may not be independent (Matui, 2010). For instance, the World Bank (2018) report on energy sector development also indicated a substantial risk of political governance relating to the implementation of the projects. A possible explanation for this would be that there had been a frequent appointment of members of the Board and Chief Executive officers of PNG Power Ltd. This suggests potential risks of political interference in the governance and management of the project by PNG Power Limited and DPE involving a huge amount of finance. Moreover, it also seems to broadly support the work of other studies in this area related to the petroleum laws that found that, while relevant laws exist, they had not been complied with (Kuwimb, 1999). There are two possible explanations for these findings. One is that, for reasons of economic efficiency and effective management, these institutions were created to avoid political interference as experienced in the previous arrangements. Another possible explanation may be that political actors were motivated to pursue and maximise their personal economic interest in the government's business at the expense of the country's interest.

\section{LNG contracts lacked public scrutiny}

Secondly, it is somewhat surprising to note that some of the commercial contracts between the State and oil and gas companies evaded public consultation and scrutiny. That is, contracts awarded by the government to the developers were not transparent because they did not involve key stakeholders in the interest of good governance. This was the situation, for example, in the second LNG project in Gulf of Papua as described by some participants in chapter six. It showed that the contract between the State and developers about Gulf of Papua project was negotiated without proper stakeholder consultation and public scrutiny to capture national interest. In chapter six, we noted that the NRI also raised a similar concern in its 2015 report that petroleum and gas contracts were strictly confidential and that there was a need to make them more transparent in the interest of good governance. These findings raise intriguing questions regarding the extent of the non-transparency of some of the commercial contracts between the state and IOGCs and NOGC. According to some participants, certain contracts did not comply with standard or expected processes such as stakeholder negotiation. In most cases, contracts are rushed through without proper consultation with key stakeholders such as landowners, thereby evading adequate scrutiny. Further, participants, based on their experiences, suggested that geopolitics or rent-seeking 
might have influenced the manner in which political, economic, and policy actors negotiated contracts in such a non-transparent way. This finding may also help us to understand why there have been numerous landowner strikes in the face of obscure information and unanswered questions about who benefits, and to what extent, from these contracts.

\section{Financial reports of the $L N G$ revenues lacked transparency}

Thirdly, it is also interesting to note that financial reports of the government including IOGCS and NOGCs were partial, obscured or secretive. For instance, as revealed in chapter two $^{27}$, KPHL and $\mathrm{KCH}$ had not tabled their full annual financial reports to the parliament since their operation began (Parliament of PNG, 2018; Nicholas, 2018). According to the Auditor General's report (2016), these SoEs failed to provide accurate information. A striking finding is that some of the key documents relating to governance and management of LNG such as financial reports, policy briefs, minutes of meetings, were not open or disclosed, let alone made easily available to the PNG public. It is perhaps not surprising also to note that, in rare instances, where information is publicly available it tends to be contradictory and varies across sectors and institutions as, for example, a report on taxation relating to LNG (Callan, 2013). This finding is consistent with that of PNGEITI reports $(2016,2017)$ and Tax Review reports $(1,2)$ which confirm that the revenue-generating institutions and producing institutions had not been reporting their financial performance to Parliament as a requirement provided by their respective legislation. In addition, this finding corroborates the idea from Margaret Callan (2013) that there seems to be a significant disparity of information reported by the IOGCs. She brought to the fore a clear transparency issue. There are several possible explanations for this finding. First, it is possible that malpractices could have been one of the reasons these institutions failed to report their performance. Second, that this finding is likely to be related to confidentiality of the companies and the State. Third, it is likely that the government might simply have wanted to avoid public scrutiny of the way it conducts its business.

\section{Inconsistency in policy implementation in ensuring transparency and accountability}

Fourthly, the findings also indicate that the government was inconsistent in policy implementation in relation to ensuring transparency and accountability in the petroleum and energy sector as shown in governance reports in chapter two, governance documents

\footnotetext{
${ }^{27}$ The analysis of governance and accountability reports is in Apppendix 9. Hence, in this chapter, I will refer to these reports as in chapter two.
} 
in chapter five, and practitioners' perspective in chapter six. This finding appears consistent with a World Bank report on a renewable energy project in PNG where it reported an unsatisfactory result of the implementation of the project due to a lack of capacity and capability (World Bank, 2018). Many of the recommendations provided by key institutions such as PNGEITI and NRI were not taken seriously (Tax Review 1, 2; NRI, 2014). This finding supports previous research done by Sovacool et al. (2016) that most EITI countries did not perform better in compliance to EITI with respect to this indicator. This inconsistency may be due to a lack of political will. In the absence of political and public pressure, it is not unusual for governments to ignore high-level advice on good governance.

\section{Lack of landowners' voice and participation in the development of LNG, despite the existence of a development forum in accordance with the existing legislation.}

Fifthly, the findings indicate that there was a platform established by the government through the petroleum legislation for the landowners to be included in the development of LNG. The current legislation on LNG governance in chapter five provides for the government through the Minister responsible for petroleum and energy to hold Development Forums where important stakeholders, particularly, landowners participate in the process of exploration, extraction and benefit sharing (GoPNG, 1998a, 1998b, 2002, 2007, 2012, 2014 2015b, 2015c, 2015d, 2015f; Voigt-Graf, 2015; Anoser, 2013). Despite this requirement, as indicated in chapters two and six, some of the important landowners were not actively engaged in national forums. For instance, one landowner when interviewed during the 2017 Petroleum and Energy Summit in Port Moresby confirmed that some of the legitimate landowners were deliberately isolated from the Summit. One possible reason given by the landowner was that the Government and IOGCs did not want those legitimate landowners to jeopardise the Summit by airing their neglected issues.

Another interesting finding is the claim that the landowners were partially empowered to participate in the development of LNG. The government, revenue-generating institutions and producing institutions claimed that money had been spent on landowners as part of their social responsibility (Aopi, 2017; Barry, 2017; Kongoi, 2017; Patjole, 2017a, 2017b). Yet, the evidence gathered in this research shows that the government and revenuegenerating institutions had done little in promoting landowners' participation in spin-off benefits, such as small scale business contracts.

In summary, the findings show that despite the existence of legal accountability system and structures in governing LNG energy, its implementation in practice, in respect of 
transparency, public scrutiny, and voice remains a critical challenge. These findings are rather disappointing because, despite significant reforms over the last couple of years in the sector, there had been little effort to hold policy and political actors accountable in decisionmaking concerning management of LNG revenues. (Kuwimb, 1997; Matui, 2010; NRGI, 2017; PNGEITI, 2016, 2017).

\section{B. Government Effectiveness}

Public value is what the people of PNG must expect their government to provide. But this can only be provided if the government systems and structures including processes are effective and efficient.

\section{Government's response to energy security issues was based on a piecemeal or an ad-hoc approach.}

Government effectiveness is one of the key indicators of quality political governance. With respect to this quality in the LNG energy governance, the findings indicate that the government's response to energy issues had been piecemeal or ad-hoc. This was clearly shown in chapters five and six. For instance, some participants stated that energy security was not given priority by the government until recently. This finding is supported by other reporting outcomes on energy security in PNG (GoPNG, 2015; SPC, 2012) confirming that the energy sector and energy security had not been prioritised since the 1990s.

This finding is not encouraging. Notwithstanding some recent efforts, we saw in chapters five and six that energy policies had, over the timeframe of the research, not been proactively developed to respond to energy security issues related to LNG. There are possible explanations for these findings. One is that there was a lack of understanding of the concept of energy security in the public sector. This has been demonstrated in the various definitions provided by the participants. Another possible explanation could be that where energy laws and regulatory legislation and institutional arrangements exist they were too loosely coordinated which reduced their effectiveness. This view appears to be in line with the SPC (2012), George (2013) and PNGNEP (2016) on energy regulatory regimes. A third possible explanation could be that politics of sector coordination may have affected the sectoral collaboration, harmonisation of policy regimes, and geopolitics. Participants' views are in accordance with the latter. 


\section{Lack of capacity and capability}

Another important finding is that the capacity and capability in the area of energy had been lacking since the 1990s. In chapter six, we saw that some participants indicated a lack of understanding of energy security as a policy area. The PNGEP clearly identified the need to build capacity and capability in the energy sector. This finding is supported by previous reports (GoPNG, 2016; SPC, 2012; World Bank, 2018). Lack of capacity and capability over time appears to have affected the government's response in dealing with energy security issues. This finding may be explained by the fact that the government did not prioritise and invest adequately in skilled human capital across all the institutions involved in LNG governance in the country and in the sector as a whole.

\section{Regulatory Quality}

\section{Weak regulatory energy regime}

A robust regulatory environment is an important quality of LNG energy governance that would be expected to stabilise the energy regime and ensure effectiveness and efficiency. In chapters three, five and six we learnt that the government had provided a regulatory environment for the governance of energy. That is, it established institutions and policies and laws to regulate the energy sector. The important policy-relevant finding from chapters two, five and six is that the energy regulatory regime in practice was not that effective. The study found that some of the laws, and policies and institutions were weak in implementing and regulating LNG. The regulatory regime also posed some risks (political, economic and legal) to potential developers. This also accords with Kuwimb's (1997, 2010) earlier observations and reports (SPC, 2012; PEITI, 2014, 2015, 2016, 2016; Tax Review Report $1 \& 2$; Deszcz \& Ladbury, 2006). The findings showed non-compliance and inadequate compliance with the laws. Here it is worth citing the tax avoidance by some companies mentioned by some of the participants in chapter six. Further, the regulatory regime, borrowed from the former colonial power following independence has divested the indigenous resource owners of their ownership, and property rights, over natural resources. Instead, the arrangements have enriched the MNCs and local ruling elites in exchange for licensing fees and non-controlling equity, leaving many impoverished and underdeveloped. This is a legacy legal problem because the law has not really changed ownership rights after it was transferred from the colonial administartion to PNG in 1975. This finding is consistent with that of Kuimb's $(1997,2010)$. This inconsistency may be due to the ongoing 
reforms in the energy sector, lack of sectoral coordination, and lack of capacity and capability, political interest, and geopolitics. It seems possible that these findings could be related to the lack of political will to implement laws as intended and political interference in the regulatory processes.

\section{Rule of Law}

\section{Non-compliance with the existing laws}

The rule of law is an important quality indicator of a stable political and policy regime. Where there is legitimacy in the rule of law, political governance becomes effective in ensuring that public value is delivered efficiently in a more transparent and accountable fashion. In chapters three and five we learnt that the government has created an enabling governance environment for the LNG sector with institutions, policies, and laws to regulate it. Seen in this light, one of the interesting findings is that, while a regulatory regime exists, political actors and policymakers did not seem to observe the institutional legal requirements, the so-called rules of governance as indicated in chapters two, five and six. Political actors tend to operate outside of the rules and change the rules of governance when it suits them. It is possible that such behaviour may be influenced by political and economic interests other than national interest. The UBS loan is a potent example of how the government bypassed the existing laws to secure a loan to fund Oil-Search Ltd liquidity. That is, the Financial Regularisation Act was not observed when obtaining the loan as was clearly underscored in chapter six. This finding of questionable ethics in decision-making is in agreement with those of Kuwimb $(2007,2010)$ and NRI $(2015,2014,2017)$ in that, despite the existence of relevant laws, political and policy actors had not observed them. Compliance with existing policy and legislation had been the main problem in the energy governance regime. It has allowed continuous unconstitutional and undemocratic practices where governing institutions were undermined because political actors tended to see themselves operating to a set of different laws compared to policy actors. Such a political practice increasingly diminished the credibility of the policies, laws, and institutions. This finding supports the idea from that of Sturesson's (2015) and Orogun's (2010) that oil rents tend to induce corrupt practices and undermine rule of law, whilst also confirming the association between oil rents, corruption, and security. 


\section{E. Control of Corruption}

\section{Lack of control of corruption had affected governance of energy}

Corruption in the country determines the level of transparency in a state system. The level at which it is measured or assessed also determines the security of the state. Whilst it is acknowledged that the possibility of corruption exists in the system and can penetrate all levels of democracy, the State has the ultimate responsibility to create an enabling environment through an effective body of laws that minimise its occurrence.

In chapters three, five and six we saw the energy governance regime in terms of its policy and legislative arrangements. This study found that there seem to be no effective laws in controlling and minimising corruption in the management of LNG and revenues, for example, the delay of the Independent Commission Against Corruption Bill as emphasised by participants in Chapter six. Another pertinent example already noted was the absence of safeguarding measures such as the Leadership Code and Public Finance Management Act in the KPHL and KCHL. Such gaps may be exploited for unethical practices in the governance of LNG. The legislation had some loopholes, for example, absence of the Leadership Code and Public Finance Management Act, which may possibly have created the opportunity for malpractice and, according to participants appeared to be the case in some instances. For example, chapter five clearly showed that almost all the LNG energy legislation has provisions for avoiding situations where a conflict of interest in decision making is possible. This inference was confirmed by the participants' responses in chapter six. Yet, in spite of this, previous studies, reports on leakages in the management of LNG revenue (PNGEITI, 2016, 2017) and the findings of this research all confirm the unconstitutional practice of lending and borrowing of money through a mortgage (NRI, 2017). This finding is in agreement with Baland (2000) and Torvik (2000), Bhattacharyya and Hodler (2010) Tsani (2015), empirical studies that show clearly there is a positive relationship between governance, corruption, weak governance institutions and resource curse. Avalos, et al. (2015) in their study of Dutch Disease in PNG arrived at the same conclusion, contending that lack of mechanisms to control corruption also signalled Dutch Disease since the political actors seemed to be seduced by rents from LNG and ignored other relevant sectors. The findings of this latter study also confirm the associations between resource curse, Dutch Disease, and corruption in PNG. 


\section{F. Political stability and absence of violence}

An effective enabling environment is expected to provide political stability for a stable economy because without it security of the state is at stake. Where there is instability it precipitates tension, violence, and conflict.

\section{Change of policies and laws by the ruling government for a political purpose}

Yet, from the analysis, it is clear that the policies and legislation tended to change unpredictably with the ruling government. The political explanation for the change usually went under the pretext of economic efficiency. In chapter three we learnt that two different governments had introduced policy reforms in energy governance. The Somare government had reformed the institutions from the previous government and introduced new legislation and institutions. For instance, the Somare government replaced the Privatisation Commission established by the Mekere government with IPBC. However, this reform was later rearranged under a different name by the O'Neill government; the IPBC was relocated into $\mathrm{KCH}$ and subsidiary companies. The analysis of the legislation in chapter five indicated that the repositioning of energy governance by the two different governments had little, if any, significant impact on transparency and accountability. Instead, each set of the reforms increased the power of political actors in the governing institutions. Practitioners of energy governance stated in chapter six that the policy and legislative reforms were politically driven. A good example could be seen from Petromin, $\mathrm{KCH}$, and KPHL where more powers were vested in the Prime Minister as the Trustee Shareholder acting for and on behalf of the people of PNG. The implication of such policy regime change by different governments is that too much power is vested in the hands of political actors and may lead to unethical and unsound economic decisions. The unethical political interference by the ministers under the Somare government in the governing boards of IPBC as indicated in chapter five is a clear case in point. This finding is supported by key governance documents and the practitioners' perspectives detailed in chapters five and six which show conclusively that the legislative and policy framework for energy governance was not stable across different governments.

This observation also makes the frequency of policy regime change pertinent. One possible reason for this legislative and policy instability could be related to the underlying laws governing party politics and elections and what is deemed to be best under the prevailing circumstances for the good of the country. Another possible reason may be the nature of 
politics in the country as described in the chapter two of the thesis. This finding suggests that frequent political and policy change can affect energy regime stability.

\section{Despite no major disruption to LNG the strikes and protest by landowners over their outstanding demands would escalate into civil unrest and even civil war.}

Another important finding is that, despite the tribal wars in the LNG site areas there had been no major disruption to LNG, except that there were some landowner strikes or protests over their unmet demands promised by the Government and IOGCs and NOGC. In chapters two, five and six, we learnt that the BSA arrangement had not been properly conducted by the government and the developers to accommodate landowners' interest. It is interesting to note that all participants interviewed perceived that a potential threat may be the disruption of the LNG should the government and IOGCs and NOGC continue to fail to meet landowner demands. Civil unrest and even civil war is perceived to be more likely the longer the government and IOGCs ignore unmet demands and governance issues.

This finding seems to be consistent with other research and reports (Chambers, 2016; Fletcher, 2013; Garnaut, 2011; Graue, 2017; Ila'ava, 2014a, 2014b; Main, 2017; Radio New Zealand, 2017; Deszcz \& ladbury, 2006), which found that civil conflict is likely to occur in oil-rich countries where corruption is systematically rife. It is interesting to note that LNG-related violence was observed in 2018 (Main \& Fletcher, 2018). Thus, this study does observe some of Sturesson's (2015) and Orogun's (2010) findings continuing to exist. That is, a resource curse due to factors such as weak institutions and governance; social fragmentation; lack of political inclusiveness and the opacity of Production Sharing Agreements (PSAs) signed by politicians and oil companies; resource control; revenue allocation and petroleum politics. In addition, these findings further corroborate the ideas of Barma, et al. (2012), Kuwimb (2010), and the World Bank (2001) that development is best understood from a power politics perspective. In general, this finding also confirms the association between resource (oil) governance and security. 


\section{G. Open Data}

\section{Lack of open data about energy governance}

Open data is an important indicator to demonstrate how transparent a country is about its conduct of business. Open data involves disclosing information for public consumption and, in so doing, it promotes transparency in the way a government functions.

Data about government performance should be seen to be open to public scrutiny and public use. PNG has been a member of the Open Government Forum since $28^{\text {th }}$ October 2015. Since then, the country has been struggling to be more open to all of its citizens (Kale \& Yabon, 2016). The LNG energy is no exception.

Based on this indicator, one important finding in this study is that the data on LNG revenues, in most cases, had not been made public, open and transparent. This finding is consistent with the PNGEITI reports (2013, 2014, 2015, and 2016) and NRI (2015). Further, there is a lack of transparency about the operation and performance of the various governance institutions created by government for the LNG sector. This was clearly brought to light in the governance documents and participants' perspectives in chapters five and six respectively. There are several possible explanations for this finding. One might be that the Government lacks capacity and capability. Another possible explanation is that the Government and IOGCs tend to maintain confidentiality or secrecy of information for the State's national interest or the commercial interests of shareholders. This finding may well be related to malpractice in the management of LNG revenues. Similarly, Callan (2013), suggests that there were inconsistencies in financial reporting as part of IOGC' social corporate responsibility in PNG. Bandara (2016) also confirms the failure of some of the MNCs in publishing their financial reports as part of the CSR.

\section{Summary}

In summary, the evidence presented above seems to suggest that the enabling environment for the LNG energy is underperforming and potentially unstable. While the enabling environment seems conducive in terms of the design of its component elements, it mainly reflects the potential for investor confidence and opportunities for political actors' interestmaximisation rather than, and perhaps at the expense of, the PNG national interest. The qualities of good governance in LNG energy did not in many ways reflect the maximum benefits for an inclusive sustainable national interest. The LNG energy regime contains relevant elements but is weakened by how it has been implemented and its institutionalisation of political interest. In considering the stability of the policy-legislative 
mix, it is quite difficult to predict the timing of changes, given the tendency of unpredictable policy and weak political institutions. It is possible, therefore, to suggest that the LNG energy regime may be unstable due to the uncertainty of the ruling government. Given the non-compliance of regulations; declining rule of law; the unpredictability of political and policy change; lack of availability of information and public scrutiny, regime stability will remain a huge policy challenge.

\section{Part 2: Revenue Management}

Management of LNG revenues is strategically important for the governance of energy security. That is to say that prudent management of revenues is critical in sustaining the economy in order to advance inclusive social wellbeing. An unstable economy has the potential to affect social wellbeing and generate social chaos. The findings of this study demonstrate that the LNG revenues have not been prudently managed. This part discusses these findings under three headings: a) National Budget; b) Subnational Revenue Sharing; and c) the Sovereign Wealth Fund.

\section{A. National Budget}

The fiscal budget had been affected due to $L N G$ revenues being mortgaged to the financial institutions by the government

In chapter two, we saw that the NRI report on SWF clearly discouraged the government from saving LNG revenues offshore due to the previous experience of mineral stabilisation fund and market volatility. The same report went on to recommend that the government should consider investing these revenues in the immediate socio-economic needs of the country. This is because there is no guarantee that offshore savings would yield higher returns, due to the political tendency towards corruption and unpredictable financial markets.

Accordingly, my data confirms that the LNG revenues were actually mortgaged to the financial institutions by the government instead of generating profits during the production and export of the LNG. As a result, the national budget was affected because funds from LNG revenues were managed by the international financial institutions outside of PNG to offset the loans. In addition, my findings also reveal that there was no clear evidence showing how the government and financial institutions managed LNG revenues, in effect, 
how the loan repayment was managed, thus raising questions of transparency. This suggests that the government had possibly unethically dictated the management of revenues on how it should be spent as shown by the evidence elsewhere in the thesis. That could be possibly one of the reasons why it remained silent on this issue when questions were raised by the public and the Opposition government as shown in chapters five and six.

This study also found that the world-wide fall in oil prices did not affect the revenues received by PNG because the government had a locked-in long-term contract with its Asian buyers. In this instance, market forces played a minimal role in influencing LNG revenues. Practitioners of energy governance confirmed this in chapter six. Several reports also in chapter two pointed out that the public had had no idea where the LNG revenues were spent since 2014 (ADB, 2015; Associated Press, 2017; Blades, 2016, 2017a, 2017b, 2017c; Flanagan, 2015, 2016; GoPNG, 2015a, 2016, 2017; Howes, 2017; Levantis \& Osborne, July 2015; Odhuno, 2016; Sean, 2012; Tlozek, 2017).

\section{Energy governance depends on the quality of political institutions and these are government specific.}

Another significant difference was observed between the management of the macroeconomy and economic performance under two different ruling governments in the 20022017 period. Under the Somare government, there was a decade-long period of economic growth during which there were also governance and corruption issues identified, for example, appointment of their cronies in senior positions. In this period, the economy had a huge surplus against spending.

By way of contrast, in 2015, the O'Neill government recorded the highest budget deficit in history. The 2015 estimated deficit budget sharply increased from 4.4 percent GDP to 9.4 percent as indicated in chapter one (Flanagan, 2015). Chapters three, five and six have provided some insights into the differing economic performance of the two governments. One explanation of this could be that the OLIPAC created the circumstances for relatively long lasting and stable governments and sound fiscal policy that stimulated economic growth. Despite the impressive decade-long economic growth that occurred, the Somare government was not able to translate this into tangible development outputs and outcomes (Morauta, 2012; Post Courier, 2017a). The PNG Peer Review Team report (2013) also confirms this. 
In comparison, the O'Neill government invested more heavily in socio-economic infrastructures. This was done despite a dramatic decline in the economy amidst increasing governance issues related to the poor management of LNG revenues and corruption issues (Batten, 2011; GoPNG, 2015; GoPNG and UN in PNG, 2015; O'Neill, 2015; Post-courier, 2017b; Teme, 2017, The National 2016c). One explanation of this result is that the O'Neill Government was not able to prudently manage the economy and this led to a dramatic economic decline and eventually economic and financial crisis (Blades, 2016a, 2017a, 2017b, 2017c; Teme, 2017; Flanagan, 2015; Hayward-Jones, 2016; Howes, 2017).

These findings are both supported and contradicted by some of the existing literature. First, corruption contributes to negative economic growth as shown under the O'Neill government. This view confirms Mendez and Sepulveda's (2006) argument that corruption negatively contributes to economic growth in democratic countries. Second, corruption does not necessarily contribute to negative economic growth, as shown in the Somare government. This view is observed by Acemoglu and Verdier (1998) where they argue that corruption tends to contribute to development, and can even be desirable at manageable levels, because it works somewhat like a piece-rate pay for bureaucrats thus inducing a more efficient provision of government services. Third, the corruption and economic growth observed is specific to the Somare and O'Neill governments. Despite the positive economic growth under the Somare government, the energy regime (institutions, policies and legislation) and political institutions, in particular, appear to be quite unstable and weak. Interestingly, corruption did not affect economic growth in this period. This seems to be in agreement with Aidt, et al's (2007) argument that corruption has little or no effect on growth in weak political institutions. During the reign of the O'Neill government, after the political impasse in 2011, the quality of political institutions and policy regime began to diminish, for example in the securing of the UBS loan by the government in the absence of parliamentary scrutiny. Yet again, this was apparent in the political interference surrounding the appointment of the Chief Executive Officer of KCP and Boards of SoEs. Interestingly, corruption negatively affected economic growth compared to the Somare government. This finding seems to be inconsistent with the finding of Aidt, et al. (2007) that corruption has negative effect on growth in high-quality political institutions. Both the Somare and O'Neill governments) governed the economy through weak political institutions but performed differently as indicated by different economic growth patterns. 
This inconsistency, observed in the findings of this study not only suggests that the relationship between corruption and economic growth remains as yet inconclusive but also that the quality of institutions varies across countries and influence patterns of corruptioneconomic growth in resource-rich developing economies.

This finding further support previous studies, in particular, Baland (2000) and Torvik (2000), Bhattacharyya and Hodler (2010) Tsani (2015) that massive windfall revenues from oil tend to induce poor management of revenues; corruption; decaying governance institutions and conflict. This is also in accord with recent studies by Avalos, et al, and Kuwimb (2010) indicating signs of resource curse and Dutch Disease in PNG.

\section{B. Subnational Revenue Sharing}

\section{Inconsistency in sharing of revenues at the sub-national level}

The subnational governments (including the host provinces of LNG) benefit directly or indirectly from the windfall of revenues through the national budget and benefit-sharing arrangements for the host province. This is intended to ensure equal benefit sharing for development purposes. With respect to this indicator, the study found in chapters two, five and six that there was an inconsistency in the sharing of revenues at the subnational level. As mentioned in the literature, LNG revenues that were supposed to be redistributed to the Provincial and Local governments as the hosts of LNG were not clearly indicated in the study. The non-disclosure of some of the relevant information makes this finding inconclusive. It appears possible that some of the resource-poor provinces may not have had benefited from the LNG revenues through the national budget due to a deficit associated with excessive loans or malpractices or corrupt practices. That is to say, the resource-poor provinces usually benefit indirectly from the LNG revenues through the national budget. But if the funding from the budget is diverted elsewhere through misappropriation, they would benefit less. In other words, mismanagement of funds at the national level seemed to have a systemic effect in terms of allocation and distribution of benefits to not only the LNG areas but to wider society. The findings by Anoser (2013) on the weakness of BSA in achieving its intended purpose appear consistent with the finding of this study. In addition, this finding seems to be consistent with that of Amanda Watson and Colin Wiltshire (Watson, 2016; Colin 2014) on corrupt practices in the PNG's Public 
Financial Management System. What is more, this seems to be consistent with Reilly's research (Reilly, 2015) on the failure of service delivery at the sub-national level in PNG.

\section{Sovereign Wealth Fund}

\section{The SWF was not fully operational in safeguarding $L N G$ revenues}

The SWF is an important mechanism that was intended, according to its legislation, to govern and manage LNG windfall or revenues in a prudent manner for future generations and development purposes.

In chapter five we learnt that the SWF was amended twice by the O'Neill government due to procedural matters. However, research uncovered the fact that the SWF, which was established by the government through an Organic Law to manage LNG revenues, was not practically effective despite the efforts of various government agencies such as Treasury, Finance, Bank of PNG and National Planning and Monitoring. The study also unearthed the fact that SWF rules were amended several times and important safeguarding components were removed without considering the political and economic implications as clearly underlined in chapter two. Compared with previous similar arrangements in the 1990s, revenues were found to have been mismanaged and squandered and this mismanagement eventually led to an economic crisis (Chand, 2015; Osborne, 2015; VoigtGraf, 2015). The findings of this study indicate that LNG revenues were managed in practice by institutions other than the SWF as was intended by the legislators. This finding is rather disappointing because changes in the form of SWF had delayed such an important part of the intended governance institutional framework.

\section{Summary}

In summary, the current study found that the governance regime had not led to prudent management of the LNG revenues. There was no transparency of how and where the revenues were spent and this generated energy security concerns. In particular, the host regions did not appear to receive the expected share of the benefits and this generated unrest against the government and its actions. 


\section{Part 3: Value Realisation}

Value realisation is an important aspect of assessing public value produced by government's policy choices (PNGHDR, 2014). That is to say, whether the policy choices made by the government generate wealth and redistribute value equally in the society to advance social well-being. In this context, the findings show that PNG benefits little from its governance of LNG resources despite a massive windfall of LNG revenues. This part discusses these findings in respect of: a) State-owned Enterprises; b) Taxation; c) Licensing; and d) Local Impact.

\section{A. State-owned Enterprises}

SoEs in petroleum energy had not been performing effectively to achieve economic efficiency

SoEs play a critical role in providing public value in the business environment. In essence, they were established as part of the major economic reforms that took place in early 2000 with the aim of these institutions operating efficiently and maximising value as indicated in chapters three and five. Contrary to expectations, several reports and studies in chapters two have shown that SoEs, particularly those in the petroleum energy sector, have not been efficient in generating and managing revenues. It is interesting to note that two of the SoEs (IPBC and Petromin) under the Somare government had been found to be inefficient due to corruption-related practices, while the reformed SoEs under the O'Neill government have been found to be less independent in their governance and decision making. One interesting finding is that, despite the reforms of SoEs to make them more efficient and independent from political interference, this study has been unable to demonstrate this in reality. The findings from 2003-2017 show that SoEs were occasionally politically interfered with, irrespective of the numerous reforms under state oversight or minimal state oversight policy reform. These findings are consistent with those of Falon, (2015), Matui (2010) and provide further evidence of institutionalisation of political interest in SoEs, confirmed later by a Parliamentary Report (Morauta, 2011). In addition, the findings also show that political and governance aspects of SoEs represented a substantial risk in the implementation of energy projects. The World Bank report (2018) on an energy project in PNG indicated a substantial political and governance risk which delayed the implementation of energy projects in PNG. One possible explanation for this would be that there had been frequent appointments done by the government for the PNG Power Limited 
Board members and Chief Executive Officers. These findings were not encouraging because of the evidence of continuous political interference in the operation of SOEs, which led to their underperformance and disappointing results.

\section{Powers vested in Prime Minister as the Trustee Shareholder of SoEs may lead to a conflict of interest in the governance of energy}

An interesting finding in this study was that the Trustee of the SoEs was the Prime Minister of Papua New Guinea under the new legislative arrangement, as clearly indicated in governance documents and as stated by practitioners of energy governance in chapters five and six. Thus the interests of State and the Government of PNG have been transferred to the Trustee Shareholder. This single political operator is expected to act for and behalf of the state and its citizens without the checks and balance of the parliament and the transparency necessary for public scrutiny of decisions. This was quite different under Mekere government where the NEC acted for and on behalf of the State and people of PNG, more precisely, the Oil and Gas Act 1998 introduced by the Mekere government that provided for the State to act as the Trustee Shareholder for and on behalf of the people of PNG. The Act does not clearly specify the Prime Minister as the Trustee Shareholder of the State's commercial interest. A possible explanation of this change may partly be explained by the political and economic interests of the ruling political elites manifested in the institutions. This finding may suggest that the quality of the institution may be undermined and weakened through political interests in the process of decision making.

\section{The legislative arrangements appear to have conflict with the customary landowners of the resources $(L N G)$}

Another finding to emerge from the study is that the State ownership of the resources under the land through leasing had not been changed to address customary landowner interests since the Australian Colonial Administration, despite numerous amendments. In chapter three we saw that the legislative arrangement was supposed to have addressed the customary landowners the right to equally benefit from the resources on their land, however, as shown in governance documents in chapter five, this conflicted with the State's and the developers' political and economic interests. Ownership of underground resources remains contested between the State and the customary landowners because the legislation provides for the State absolute right over any resources beneath the land through leasing for development purposes. This has in many ways affected the benefit sharing arrangement that led to tension and conflict such as the Bouanville crisis. This finding is significant in 
respect of four contradictions over resource ownership. Firstly, the same law under the Anglo-Australian legal system had not been amended when it was transferred to the Independent State of Papua New Guinea. Secondly, the Melanesian concept of communal ownership is based on traditional (informal) norms and values. Thirdly, the land and the resources beneath it are a strategic asset of the State that must not be left to 'private hands'. Fourthly, the land has been taken as a commodity for monetary value. This finding corroborates the idea of Kuwimb (2009) that there existed a dilemma on the notion of land ownership and benefit sharing arrangement.

Finally, this finding could be related to a 'black colonialism' where the ruling elites may have had used the existing colonial institutions to pursue and maximise their political and economic interests. This finding is supported by one participant and Kuwimb's (2010) research on resource curse in PNG.

\section{B. Taxation}

\section{The taxation regime was weak}

The taxation system is important to generate government's revenues in order to maintain political and economic stability. And this depends largely on a fair tax regime associated with transparency, voice, and accountability in the taxation system. Based on the assessment of this indicator, the collection of revenues by the relevant institutions were not sufficient to feed the fiscal capacity of the State as was clearly revealed in governance reports, documents, and the practitioners' perspective in chapters two, five and six. Another important finding is that the tax regime in the energy sector was weak because IOGCs and NOGC were unfairly exempted from tax. There had been instances of tax avoidance by companies. One explanation for this is that the government wanted to promote foreign investment and drive private sector growth in petroleum energy. It is also interesting to note that, despite the existence of a tax regime, there was a lack of enforcement by the Internal Revenue Commission, PNG Customs Services, and Department of Finance. Several reports have shown that administration of tax has been a policy challenge (Tax Review 1, 2; NRI Report, PNGEITI, 2013, 2014, 2015, and 2016). One possible explanation could be that there was a lack of sectoral collaboration between the sector agencies. Another possible explanation could be the lack of capacity and capability in tax administration. A third possible explanation could be that rent-seeking may have influenced exemption of taxes 
offered to the companies by political actors. This finding further supports the idea that the tax regime in PNG is weak and outdated, a finding that is also consistent with the PNGEITI (2013, 2014, 2015, and 2016), PNG Tax Review (1, 2) and Sturesson's (2015) study of EITI in Uganda.

\section{Licensing}

\section{Lack of stringent licensing regulation}

Licensing in the petroleum energy sector is important because it generates revenues from prospective investors. The system and processes are critical areas that ensure compliance in the value chain. Accordingly, the finding of this study indicates that the licensing aspect of the petroleum energy sector was quite weak because there were compliance issues with the regulatory requirements and administration issues that needed to be improved in order to attract foreign investors. The governance reports and practitioners' perspective in chapter two and six drew attention to licensing as one of the main concerns in energy governance. This discrepancy could be attributed to a lack of capacity and capability. These findings might also suggest that there is a possibility of political interference with the licensing, thereby making the value chain riskier. This finding may somewhat be limited by the depth of the study. However, this finding is consistent with that of PNGEITI $(2013,2014,2015$, and 2016), Sturesson's (2015) and Deszcz \& Ladbury (2006). A commentary by the Director of Institute of National Affairs on the question of whether the LNG project was really that good, exposed the weak regimes in licensing within the Department of Petroleum and Energy that need to be improved to allow for transparency and accountability (The National, 2017). The acting Secretary for the DPE also believed that there is a need to effectively improve the regulatory aspect of licensing to function efficiently (Pacific Mining Watch, 2017).

\section{Local impact}

\section{There was little impact at the local level despite $L N G$ revenue generated}

The impact of LNG revenues is determined by the degree of benefits distributed to the local areas, especially the host areas. In chapter three it was argued that LNG is expected to benefit the country, however, the current study found that there was little impact at the local level despite some investment in basic socio-economic services by the IOGCs and NOGC, 
as indicated in the governance reports and by the participants' perspective in chapter six. It is interesting to note that the landowners had not seen the tangible outputs and outcomes as promised by the Government, IOGCs, and NOGC. Participants' responses and a Media Press Release by the PNG LNG Project Beneficiary Group (The National, 2016d) confirm this finding. This is also supported by Callaghan's (1990) research into the host areas of LNG and those of George (2013), Imbun (2006), and Gilberthorpe and Banks (2012) who claimed that IOGCs and NOGCs had not effectively executed their CSR's objectives in supporting local community development. One explanation of this finding could be that the IOGCs seem to be more profit-oriented than the moral and social responsibilities. Another possible explanation could be that there was no proper social mapping done prior to the project.

In addition, the study found that there had been massive investment in the local areas through service delivery policy of the government as the O'Neill government replaced the Somare government. Despite that, in relative terms, some of the provinces and districts at least witnessed tangible outputs and outcomes. The variances in this finding suggest that, while there has been a huge investment in these areas, management at the sub-national level may have affected the distribution. Another explanation might be that wealth could have been spent in a very biased way, partly due to politics of the government and the Opposition. This finding accords with that of Watson, et al, (2016), who asserts that corruption in the public finance management system has affected service delivery.

\section{Summary}

In summary, the current study found that the energy sector was not able to effectively or efficiently produce public value and equitably redistribute wealth to the society due to issues associated with inefficiency and weak governance such as malpractice or corrupt practices. As a result, PNG has benefited little from LNG extraction despite the massive windfall of revenues.

\section{Part 4. Security}

This part begins with three key policy statements from international organisations and GoPNG. The first statement is from the UNDP Report of 2004 which generally points up the link between energy, human security and human development and states that:

There is, of course, a link between human security and human development: progress in one area enhances the 
chances of progress in the other. But failure in one area also heightens the risk of failure in the other... Failed or limited human development leads to a backlog of human deprivation poverty, hunger, disease or persisting disparities between ethnic communities or between regions. This backlog in access to power and economic opportunities can lead to violence. UNDP, 1994.

In the same vein, the Natural Resource Governance Institute (2018) reinforces the general statement from UNDP by focusing specifically on how governance of natural resources such as LNG energy may contribute security and poverty.

Improving natural resource governance is one of the most significant development challenges of the decade and will determine the future of 1 billion people globally who live in scarcity in the midst of resource abundance. Countries with non-renewable resource wealth face both a challenge and an opportunitywhen used poorly or squandered, non-renewable resource wealth can cause economic instability, social conflict and lasting environmental impacts; used well, they can create prosperity for current and future generation. Natural Resource Governance Institute, 2018.

This global policy agenda has been embraced at the national level by GoPNG. GoPNG has aligned its national security policy with the UNDP Report of 2004 by establishing the inextricable link between security and development that has relevance to the governance of energy security.

National Security is inextricably linked with development. Mindful of this, the NSP is linked to the Constitution, the PNG Vision 2050, The PNG DSP 
2010-2030, MTDP 2011-2015, the Defence White

Paper and Foreign Policy. This is necessary because national security encompasses cross-cutting issues in domestic and international spheres. GoPNG National Security Policy 2013.

The three statements above underpin the relationship between security and development which, in turn, inform us how government needs to allocate and distribute scarce resources such as LNG energy equally to society in an efficient manner without harming its fabric.

The PNGNSP is informed by the UNDP's new concept of security: a shift from traditional security (state-centred approach) to human security (a people-centred approach) capturing political, economic, social, and environment dimensions. The policy delineates how resources are externally and internally exploited by state and non-state actors through corruption, for instance, how they may affect humanity in the broader context, for example in the interdependence of human development and the political governance of energy.

\section{Energy governance has an interdependent relationship with national security and development.}

It is argued, as above, that within the context of national security-human development nexus, the political governance of LNG energy has a link with security and development in many ways, for example, a stable political environment guarantees the security of a stable economy. Accordingly, this relationship depends on the quality of political institutions constructed by a ruling government. As mentioned in the literature review, a weak political governance system tends to affect economic growth and development, in particular human security, thereby generating energy insecurity. Similarly, a strong political governance system enhances energy security thereby yielding economic growth and development. This idea is consistent with Johansson's (2013) definition of energy security outlined in chapter one and in the literature review in chapter two.

Based on the above central argument, on the question of whether political governance contributes to energy security in PNG, this study found that there was a link between governance, energy, security and development. The findings from this study generally demonstrate that governing LNG energy at the institutional level contributed to energy security in two significant ways. 


\section{A weak energy regime generates energy insecurity instead of enhancing energy security}

The first matter of significance is that the study found that a weak energy regime tends to 'generate insecurity'. This energy insecurity is characterised both by lack of transparency and accountability and inconsistency, and lack of continuity, in governance and policy institutions and setting. In chapter three we noted that energy governance leads to enhanced energy security; however, in chapter five it was made clear that the existing legislation has proved weak in addressing issues relating to transparency and accountability. One possible explanation could be that a weak regime allows malpractices such as corruption and political interference to take hold in the enabling environment. That is, a weak regime creates a porous enabling environment for the exploitation of resources by political and economic actors with vested interests that are institutionalised and changed with the ruling government. These practices have tended to create instability and uncertainty, and affect adaptation to changing environment as the study indicates. Correspondingly, a weak regime tends to yield negative development outcomes. An important finding in this study is that negative development outcomes caused by a weak regime present themselves as human security concerns because it affects the 'freedom of fear' and 'freedom of want' associated with human development as shown in chapter one and governance reports and the practitioners' perspective in Chapter two and six. This finding confirms the association between security and development (UNDP, 2014; GoPNG, 2013) and corroborates the ideas of Hudson (2014) and World Bank (2008) that power politics is critical in understanding patterned development outcomes.

The evidence in this study suggests that a weak regime could generate insecurity when corruption affects national budget. Further it shows that poor management of LNG revenues has significantly affected the payment of landowners' benefits and precipitated protests in the LNG sites, as demonstrated in governance reports and the practitioners' perspective in chapter six. The most obvious finding was that poor management of LNG revenues could, in the words of a participant, 'strike the match', that is trigger civil tension and crisis should landowners' demands not be met.

Energy governance as described in chapter three indicated that a level playing field was intended to operate in the development of petroleum energy. However, governance reports and documents in chapters two and five, and the practitioners' perspective in chapter six indicated a different story. An interesting geopolitically relevant finding is that a weak regime had paved the way for greater power politics between competing multi-national 
energy giants. In turn, this created tension between the energy players and allowed external actors to penetrate the government decision-making system. As a result, the state's strategic asset was under threat from being economically exploited and economic sovereignty being undermined. This finding supports the idea that development can be affected by geopolitics and fuel resource curse, Dutch Disease, corruption, weak institutions, conflict and violence (Klare, 2001, 2004, 2009, 2016; Levi, 2010; Stevens, 2003; Stevens \& Dietsche, 2008; Ushie, 2013; Luft, 2009; Klare, 2009; Müller-Kraenner, 2007; McNeish, 2010; Collier, 2005; Kaldor, 1999; Kaplan, 1994; Nafzinger \& Auvinen, 1996; Watts, 2008; Karl, 1997; Keating \& Brown, 2015).

In addition to the above point, these findings also confirm a 'paradox of plenty' in the form of resource curse and Dutch Disease which tends to induce systematic corruption, breakdown of rule of law, decaying of governance institutions which often fuel tension, conflict and violence (Sovacool, 2014, Yergin, 2014, UNDP, 2014; Cherp \& Jewell, 2011; Yergin, 1988, 2006).

The findings also suggest that energy security depends on the quality of political institutions. A ruling government produces a set of institutions, policies, and legislation which create the quality of the governance and determine the level of security. Weak political institutions generate insecurity whilst strong political institutions enhance security. The type of institutions and level of security determines the level of economic growth and development.

Furthermore, the study found that a weak energy regime tends to affect energy efficiency and that revenue-generating institutions became increasingly ineffective and inefficient in yielding public value. The evidence clearly showed that political interference had affected the efficiency of the governance institutions.

\section{A strong energy regime enhances energy security}

The corollary and second significant point is that a strong energy regime tends to 'enhance energy security'. The literature review made a clear link between strong energy regimes and certainty and stability in the enabling environment. A stable enabling environment tends to allow the energy regime to adapt to change and effectively perform efficiently producing public value. The research in this study found that the enabling environment had been incrementally improving, yet remained challenged and ineffective due to complex 
political and economic dynamics as shown in governance reports and documents in chapters two and five and practitioners' perspective in chapter six. This difference between weak and strong energy regimes may be due to the manifestation of pervasive political and economic interests increasingly becoming institutionalised. This is in line with previous studies and reports (Sovacool, 2014, Yergin, 2014, UNDP, 2014; Cherp \& Jewell, 2011; Yergin, 1988, 2006).

The study also provided important suggestions for improving the political governance of energy security based on governance reports and the practitioners' perspective in chapter six. The two most important are political reform and policy allied to legislative and institutional reform to strengthen the governance regimes. It is argued that political will is the key to all other reforms since policy is governed within a political space. The existing policies and legislation are appropriate to the sector but there is a need to ensure more compliance. The management of revenues is critical to ensuring redistribution of wealth to advance and sustain social wellbeing. The BSA is an important arrangement that should be reviewed in a manner that is beneficial to the landowners, without which it could generate insecurity. The governing institutions also require administrative capacity and capability to implement policies and ensure compliance. In order to mitigate energy security issues such as price fluctuation and the meeting of domestic demands there is a need to encourage and promote down-streaming of energy sources and strategic stockpiling of energy reserves. These propositions would enhance the energy security system that is currently insecure due to existing and emerging threats or risks areas generated by the political and economic interactions within the state political governing system in accordance with the QEGF. These findings are consistent with those of Hassall, 2011; Cohil, 2017; Anoser, 2013; Deszcz \& Ladbury, 2006; George, 2013; NRGI, 2017, ANZ, 2013, Yergin 2006; Cherp, 2012; Kobayash, 2015; PNGNSP, 2013; DWP, 2013 and PNGNEP, 2018.

In summary, the study found that a weak energy governance regime tends to generate energy insecurity despite such measures as the introduction of policies and laws to enhance security. As a result, weak energy governance affects patterns of development outcomes.

\section{Conclusion}

By using the QEGF as an analytical framework, the study found that the political governance of energy in PNG, in particular, LNG energy governance had a significant and 
interdependent relationship with energy, security, and development. It showed that the enabling environment was characterised by non-compliance of regulations; declining rule of law; the unpredictability of political and policy change; lack of availability of information and public security. The study also showed that the energy sector was not able to effectively and efficiently produce public value and fairly redistribute wealth equally to society due to issues associated with inefficiency and weak governance. This was clearly demonstrated in the lack of transparency in managing the LNG revenues. The study also demonstrated clearly that a weak energy governance regime had generated energy insecurity despite some measures such as the introduction of policies and laws to enhance energy security.

Taken together, these findings appear significant in at least two major respects. First, is that a strong energy governance regime enhances energy security. And, in addition, its corollary that a weak energy governance regime generates energy insecurity. These findings suggest that the present LNG energy governance regime may not be able to produce a stable and adaptable political and economic system that can perform effectively and efficiently in advancing inclusive sustainable development in PNG. This might be best explained by the unpredictable behaviour that arises from regime change and that motivated by political interest and enabled by quality of political institutions. 


\section{CHAPTER 8: IMPLICATIONS AND CONCLUSION}

In this final chapter, I discuss the implications of this study's findings. My study examined how political governance of liquid fuels contributes to energy security in PNG. The interest lies in understanding how the government governs and manages LNG energy through policies, legislation, and institutions in order to establish whether these institutional structures and processes enhance or undermine energy security as a contributor to national security.

Chapters five to six analysed the LNG energy governance regime using a qualitative critical case analysis research design. The research design involved analysis of the key formal institutional structures of energy governance and the observations of participants in the governance processes and key documents relating to the critical cases of energy in PNG through the lens of political economy. Chapter seven synthesised the findings from these sources using the characteristics of QEGF which emerged from the analysis of the literature on energy governance and energy security in chapter two. In this synthesis, we see an unstable energy governance regime, non-transparent LNG revenue management, little impact of LNG on the economy and society, and energy insecurity generated by a weak governance regime about the nature of energy governance and its contribution to energy security.

From this synthesis I conclude that:

- Governance of energy security depends on the relationship between the qualities of political institutions (ruling government and politicians) and policy regime (policies, legislation, and governance organisations). A strong political institution creates the elements of a quality energy regime which, in turn, translates into an operational quality of energy governance that enhances energy security. Alternatively, a weak political institution creates a weak operation of energy governance and generates energy insecurity.

- The LNG governance regime in PNG lacks the operational and adaptive qualities to function efficiently in producing a public value. This occurs because the energy governance is perpetually interfered with by politically motivated actors of the ruling government, through the use of institutions in which they maximise their interest. In the process, it incrementally diminishes the credibility of the energy 
regime to withstand transparency and accountability issues and challenges that might contribute to energy security.

- The policy environment is complex due to the social interaction of various actors and their interests in a politically constructed governing system of institutional qualities (policies, laws, and governance organisations) which affect the energy regime and contribute to national security in an unpredictable way. Therefore, a quality energy governance system is important for its operational and adaptive qualities to respond to emerging energy governance issues and challenges that might contribute to energy security in the long run.

This synthesis makes a core contribution to our existing knowledge about the relationship between energy governance and energy security and contributes to national development. In summary, my empirical findings are that,

Energy governance is a system of interacting institutions, policies and legislation created by the political institutions for the purpose of achieving economic efficiency in order to produce public value. The effective functioning of this system depends on the quality of the political institutions. A strong political institution constructs a quality policy regime which, in turn, translates into operational and adaptive qualities of an energy regime that enhances energy security. Alternatively, where a political institution is weak, the operational and adaptive qualities of the energy governance system are also incrementally diminished and generate energy insecurity which, in turn, affects development outcomes. In the context of PNG, the qualities of the energy governance system did not seem to effectively function efficiently as a whole or as should be due to the political-economic interests and non-conformance of the institutional qualities. This, in turn, generated energy security instead of enhancing energy security. The social interaction of political and economic actors and their interests in this system is complex and quite difficult to predict, thus, producing an unstable energy regime. Given the unpredictability of this energy regime, political reform should assume primacy in the 'order of priority' to withstand emerging energy governance issues that might contribute to energy security in the long term.

This conclusion is now used to discuss the implications of the findings. 


\section{Part 1: Implications to Public Policy Theory and Practice}

The theoretical implications are directed to scholars in the fields of public policy, political science, security, and development, while practical implications are recommendations for policy and development actors. These include policy makers, implementers, development agents or partners, the private sector and civil society actors and other practitioners working in and with resource-rich developing countries.

This study has argued that the interaction of powerful political elites with the institutions of governance matters in the political governance of LNG energy. Even in circumstances where the governance institutions appear adequate for good governance, this is not the observed outcome. It has shown that a change in the ruling government has changed the energy regime for a political purpose under the guise of economic efficiency.

It appears that, the policy regime, in this case, the LNG energy regime in the form of laws and regulatory and institutional arrangements are subject to unpredictable changes at each change in government as political actors seek to shape the governance arrangements to suit themselves. We see periodic political changes punctuate the policy frameworks for energy governance and energy security and make it less stable and unpredictable. This change, in turn, contributes to instability and uncertainty in the enabling environment, a pattern largely driven by power politics. That is because it has both cause and effect upon public policy when there is a government change.

So what do these findings generally imply? Some elements of the QEGF come to the fore in the analysis of LNG in PNG, especially the enabling environment and revenue management. Theoretically, the interests of political and economic actors are constants but in practice they often change unpredictably with a change in government. On the one hand, the economists in chapter two tend to argue that incentives (rents) influence regime change (policy), however, this study clearly demonstrates that power politics tend to influence policy regime change. The central argument is that actors are motivated by self-interest that is to remain in power. As long as political actors remain in power they take rational steps to continue to maximise their interests by collaborating with economic actors. This sustained (symbiotic) relationship over time becomes institutionalised and is quite difficult to eradicate practically. In its processes, the governance arrangement for petroleum energy increases the vulnerability of the enabling environment, and its ability to function effectively and efficiently. The vulnerability of the environment generates insecurity and 
affects economic growth and development outcomes. A stable enabling environment provided by a strong political institution reduces the volatility of the policy regime and in the process enhances energy security, which is necessary for advancing sustainable development.

In practice, it is not always the case that a stable policy regime would lead to positive policy outcomes because of the inevitability of power politics. For instance, the delay of operationalising the SWF by the Somare and O'Neill governments has created a vulnerable environment in which the economy was not insulated from the political dynamics that led to a crisis. The same happened in the 1990s with the mineral stabilisation fund where political actors squandered the funds for political interests other than national interests. As a result, the economy descended into crisis. This seems to be a repeat of that case in 2014 as the findings show in the study.

In practical terms, if actors' interests become institutionalised it is often quite difficult to change specific qualities of political governance, for instance, amending certain sections of the legislation or policy where their interests remain deeply institutionalised. In addition, policy actors and political actors (especially those who are sympathetic to the ruling government) within the political system of policy governance often become corruption tolerant. A complacent behaviour related to 'fear of job security' would often lead to nonaction of preventing or deterring malpractices within the institutions as was the case observed in the study. In this sense, it would be quite difficult to introduce stringent governance measures; the delay of institutionalising and effectively administering the SWF proved to be the case. This has been the case as seen in the delay of an 'Independent Commission Against Corruption Act', a piece of legislation that was supposed to have established an anti-corruption institution. This includes the exemption of members of SoEs and NOGCs from the Leadership Code by the design of their respective legislation. If a change has to occur, it must then commence at the level of the political institution where policies and laws are made. This has been a practical policy challenge in the political governance of LNG energy. That is, there must be a collective political will to change the nature of political governance of public policy in the areas of energy. Political actors must take lead in changing the current deteriorating state of affairs. If that were the case, we expect a cascading and multiplier effect at all levels of development. At this juncture public policy would then seem to function effectively and achieve its strategic objectives efficiently. 
Another practical implication of the findings is that the economic security of the national economy does not only depend on energy market forces but also on geopolitics, for instance. And therefore, developing an adaptive system that is able to read signals (emerging issues) from the energy market environment is strategically important for policy resilience because of the changing nature of the political and economic environment. Policymakers should take into consideration the complexity of the energy market and how it interacts with politics of market forces. In many ways, power politics tend to have more influence over market forces. That is why the political governance of LNG has been affected since 2014 as observed in the study.

The findings also demonstrate that there is a significant interdependent relationship established between governance, energy, security, and development. This policy governance behaviour tends to lead to a certain outcome. Firstly, a weak energy regime generates energy insecurity and, secondly, a quality governance regime enhances energy security. One of the possible explanations of this policy behaviour could be that political elites tend to use the existing colonial institutions to pursue and maximise their personal interests. If that pervasive behaviour continues public policy would be captured by private interests and corruption would corrode qualities of governance often referred to as a state capture $^{28}$.

The second major finding was that the revenues of LNG had been poorly managed. An implication of this is that that mismanagement of resources may increase poverty and generate insecurity. The management of resources and revenues is critical for development. Where there is lack of prudent management or governance the notion of a 'paradox of plenty' in the form of the resource curse and Dutch Disease could potentially lead to tension, conflict and civil war. This is another of the policy challenges PNG has faced. Practically, there were signs of the resource curse and Dutch Disease, yet political actors tend to be seduced by rents from the energy sector because other sectors were not that attractive and lucrative. The reason is simple, political actors need economic incentive to remain in power. As a result, other sectors such as agriculture were not given significance

\footnotetext{
${ }^{28}$ By State capture in this study, I refer to a systemic political corruption where economic actors penetrate the government system of decision-making in order to maximise their advantage, for example when corporate companies owned by foreigners operate as a national company in the petroleum energy industry influencing commercial interest of the state. This study has observed the UBS loan as a manifestation of a state capture as reported in the media.
} 
or attention. This is also one of the legacy policy challenges in PNG which policy-makers should consider when designing responsive policies and strategies.

In relation to the above implication, an interesting compelling paradoxical pattern is observed in the study. First, the study found that it is not always a theoretical pattern that a stable (strong) political institution (ruling government) is transparent. It was established that a stable political institution with a stable policy regime seems to produce quite a positive outcome amidst corruption. For instance, the Somare government demonstrated that, despite the existence of governance and corruption issues, the government was stable and provided a stable macroeconomic policy environment for successful economic growth for a decade. Second, it is not always the case that an unstable political institution produces an unstable policy regime. The study found that the policy regime may be appropriate but could be interfered with by political actors for the purpose of interest-maximisation. For instance, the O'Neill government seemed to be unstable when it unconstitutionally overthrew the Somare government in the 2011 political impasse yet developed appropriate laws which they (politicians) appeared to have interfered with overtime. In so doing, they incrementally diminished the credibility of the policy regime to withstand the economic and financial crisis.

So what do these findings practically mean? Generally, the existing policies and laws governing LNG are appropriate but what is problematic is the implementation of them and conformity with the expected norms of political accountability by the governing actors within the institutions that matter most. Where political interest is institutionalised, even under a stable-unstable ruling government, corruption is inevitable and this may not always affect economic growth as the study indicated.

One other important implication found in the study relates to customary landownership where resources are found and the benefit sharing arrangement. Theoretically, the customary landowners of the resources are supposed to have benefited equally from the State and developers after the leasing of the land on which resources are found. Practically, this has not been the case for resource landowners, in this case, LNG landowners as cleary indicaed in the findings. Becaue the State has absolute right over any resources beneath the land through leasing for development purposes, it has the leverage to dictate the benefit sharing arrangement. This has led to contestation and conflict. 
Similarly, it seems that the LNG energy governance regime remains quite legally volatile because the ownership and Trusteeship in terms of Shareholder in the commercial interest of the State had been given to a political actor (Prime Minister) who by virtue of the legislation could be expected to act for and on behalf of the State. This study suggests otherwise. Practically, political actors are motivated beings who sometimes may behave rationally to pursue their own interest other than national interest. This is because every board officeholder is also a private person with private interests; however in many jurisdictions they are constrained to declare any self-interest and act on behalf of the shareholders (in this case the nation and people of PNG). The $\mathrm{KPH}$ and $\mathrm{KCH}$ for that matter were virtually seen to be operating as private companies although, by design, they appeared to be a State commercial entity. This contradicts the traditional practice of state ownership. This arrangement while theoretically it may sound economically viable for efficiency purposes, in practice, may be politically interfered with and therefore increasingly become less independent as the study showed.

The study also found that energy security was a relatively new concept in PNG although the idea has floated around since the 1990s. That was one of the reasons why there had been less coherence in policy development and implementation. Given PNG's strategic importance of energy security in the region, it is necessary that political actors and policy makers understand and appreciate its significance to the development of the country. Without a clear understanding of it, governance problems would continue to persist.

Taken together, these outcomes suggest that the LNG energy governance regime within the existing enabling environment is less stable than is desirable for the long-term interest of the PNG citizens. Further, its future performance is quite uncertain due to the complex political and economic interactions. This is because power politics play a central role in influencing certain outcomes or patterned development as experienced in the case of PNG. Political actors and policy actors should focus more on building an adaptive governance regime capable of withstanding short-term and opportunistic self-serving political interference. Policy actors should first understand and appreciate the dynamics of a complex interaction of political and economic actors and interests. In that way, they would be in a better position to strategically develop or design appropriate policy-relevant responses to energy security issues which have a greater impact on development outcomes and national security. 
The following are some of the practical areas of improvement:

- There should be a policy reform in terms of policies and laws about energy governance at the political level. This should be driven by a political will, without which quality policies will continue to be interfered with by politically motivated actors.

- Introduce strong punitive measures in the current legislation such as material fines, confiscation of profits and even imprisonment for law-breakers.

- Create a 'Whistle Blowers Act' to encourage those with knowledge of wrongdoing to come forward and also deter rational (politically motived) behaviour of lawbreakers.

- Operationalise SWF Act to safeguard the proceeds from LNG revenues for future generations.

- Strengthen the existing institutions by legislation in such a way as to prevent political interference.

- Review the current BSA and legislate it as a constitutional requirement to avoid strikes and civil war. A clear BSA implementation framework anchored on the BSA legislation should be developed synonymously and observed by the government.

- Build the capacity and capability of the institutions governing energy. The important areas are negotiations of projects, tax administration, management of LNG revenues, and regulation of licensing.

\section{Part 2: Conclusion}

\section{A. Significance of the study and contribution of the study}

This study contributes to our understanding of how governance of energy, in particular, LNG policies and legislation at the institutional level contributes to energy security in a resource-rich country such as PNG.

Although the current study is based on a small sample of participants, by using some relevant core qualities of the Resource Governance Index, the findings speak to the link between governance, energy and security.

While many studies, in particular economics and political science, have quantitatively and qualitatively focused on the causal relationship between resource curse/Dutch Disease and 
conflict and wars in oil-rich developing countries, very little has been done or said about the possible link between governance and energy security.

This study has demonstrated that governance of energy could lead to negative development outcomes and, therefore, national security. In so doing, it richly contributes to the existing body of energy security and bridges the link between political science, economics, public policy, energy, and security.

Finally, this study helps contribute towards improving energy governance in PNG as one of the resource-rich countries in the Pacific struggling with the syndrome of "paradox of plenty'. PNG is not immune to the natural resource problem of resource curse and Dutch Disease like many other developing countries. The country has a problem of prudently managing revenues from the resource sector, in this case, LNG. This study provides some insights on how best revenues should be managed politically at the institutional level.

\section{B. Strengths and limitations}

While the study established the clear interdependence of the quality of energy governance and energy security outcomes, there are some limitations that need to be acknowledged and discussed.

Speaking first to the strengths of this study. The topic of energy security, in particular political governance of liquid fuels (LNG energy) appears to be the first of its kind in PNG and the Pacific Islands countries. Energy security in general has been rarely studied in PNG. The focus has been on renewable energy apart from non-renewable energy, in particular LNG. PNG appears to be the only native island country in the Pacific Islands, apart from Australia and New Zealand, to possess, produce and export abundance of non-renewable energy (hydrocarbons in the form of LNG) to the Asian markets. In any event, this study is in many ways timely given the early stage of production and export amidst ongoing exploration in PNG. The findings of this study are relevant for policy discussion and advancement in this space.

Secondly, the research design based on a political economy approach lends confidence to the research findings in understanding the politics of public policy in the petroleum energy space. The methods of analysing participations' reflection and analysis of documents based on critical cases (instances) have provided significant insights into understanding the 
dynamics of governing and managing a billion-dollar industry which proves to be helpful in the public policy discourse.

Thirdly, the inclusion of security dimension into the QEGF deepens the ability of the framework in linking energy governance and security and development. In retrospect, the link between energy governance and national security and human development has been rarely studied and understood in PNG and elsewhere, particularly the resource-rich developing countries. The frameworks often used by many of the development agencies including think tanks such as the Resource Governance Institute seem to treat security as an isolated related variable. By adding the security variable into this calculus, the framework was able to explore and uncover patterns in politics of public policy at institutional level within which social interactions of multiple players and interest are played out. This is evident in the richness of the study through the prism of political economy.

Notwithstanding these strengths, the generalisability of these results is subject to certain limitations. For instance, a few of the participants, in particular the producing institutions (IOGCs and NOGC) have not been interviewed due to the timing and their busy schedule. The small sample size did not allow for the participation of some of the IOGCs. Another example is that it is quite difficult to differentiate between facts and assumptions from the participants' responses; however the participants are experienced working in petroleum energy and other sectors linked to it. A third example is that it is not possible to assess corruption in the LNG energy governance because the topic is sensitive in nature and in addition, accessibility to classified information proved too difficult. Despite these limitations, this generalisability also allows for the possibility of the study being replicated elsewhere.

The relatively limited sample in this work offers valuable insights into the understanding of how political dynamics influence policy behaviour and development outcomes and national security.

\section{Part 3: Recommendations for Further Research}

Since this research is relatively new in PNG, certain areas need further research. First, further research is required to quantify the outcomes of the governance in this study; the performance of results and how these relate to the QEGF. This study used a qualitative 
approach to understand the political governance of liquid fuels and could be extended to cover areas in renewable and non-renewable energy through a quantitative approach.

In addition, research could usefully explore how energy is governed in the renewable energy sector. PNG has untapped renewable energy resources and the government is moving into this space to complement the non-renewable energy. The potential for research in this area is important to inform policy.

Moreover, a further study could quantitatively assess how governance of energy affects economic growth and development and security. There have been few, if any, studies in quantifying the effects of energy security on the national economy. It would be relevant for more research to be conducted in this area to inform economic and social policies.

Since my study is qualitative in nature, it would be interesting, in future research, to apply a mixed methodology in this area of study. This should be applied to both renewable and non-renewable energy.

Finally, a further study should be conducted using the QEGF in the energy sector to test its applicability. Specific areas of the framework had not been previously been studied and, therefore, it would be interesting to extend the framework to test its applicability.

\section{Concluding Statement}

In general, resource-rich countries continue to face governance and corruption issues, poverty, conflict, and tension. PNG is no exception. This study has shared an insight as to how political institutions affect policies, laws, and governance organisations in the petroleum and energy sector. As we have seen in the case of PNG, the ruling governments tend to create their own policy system based on their policy platforms to achieve a certain purpose. And in most cases, this is not in the best interest of the State and citizens. Policies and laws that were supposed to have provided a safeguard for resource development were instead used by political actors in ways that are unethical for interest-maximisation. This political behaviour has consequently contributed to missed development opportunities and triggered frustrations that are likely to lead to a civil war as experienced in Bougainville. Political governance of energy security in this respect implies that the political institution is the central underlying problem, among others, that needs a comprehensive reform. 
Conversely, a strong political institution is necessary to create a stable policy environment to advance inclusive sustainable resource development. 


\section{REFERENCES}

ABC News. (2017, 1 June 2018). PNG sells Oil Search stake after deal leaves Government massively out of pocket. Retrieved from http://www.abc.net.au/news/2017-09-22/pnggovernment-sells-stake-in-oil-search/8976648

Acemoglu, D., \& Robinson, J.A. (2012). Why nations fail: the origins of power, prosperity and poverty. London: New York: Profile; Crown Publishers.

Acemoglu, D., \& Verdier, T. (1998). Property Rights, Corruption and the Allocation of Talent: A General Equilibrium Approach. The Economic Journal, 108(450), 1381-1403.

ACIL Tasman. (2009). PNG LNG Economic Impact Study: An assessment of the direct and indirect impacts of the proposed PNG LNG Project on the economy of Papua New Guinea. Retrieved from Papua New Guinea: http://pnglng.com/downloads/acil_tasman_impact_study_revision_01.pdf

Aidt, T., Dutta. J, \& Sena, V. (2007). Governance Regimes, Corruption and Growth: Theory and Evidence. Journal of Comparative Economics, 36(2), 195-220.

Allen, M. (2013). Melanesia's violent environments: Towards a political ecology of conflict in the western pacific. Geoforum, 44 (2013), 152e161.

Allen, M. (2017). Islands, extraction and violence: Mining and the politics of scale in islands Melanesia. Political Geography, 51 (81-90).

Allen, M. (2018). Resource extraction and contested States: Mining and the politics of scale in the pacific islands. Palgrave Macmillan.

Allen, M., \& Hasnain, Z. (2012). Power, pork and patronage: Decentralisation and the politicisation of the development budget in Papua New Guinea. https://epress.lib.uts.edu.au/journals/index.php/cjlg/article/view/1617

Al-Makhamreh, S. S., \& Lewando-Hundt, G. (2008). Researching `at home' as an insider/outsider: Gender and culture in an ethnographic study of social work practice in an Arab society. Qualitative Social Work, 7(1), 9-23.

Allison, G., Blackwill, R.D, \& Wyne. A. (2013). Lee Kuan Yew - The Grand Master's Insights on China, the United States, and the World: Cambridge, Massachusetts; London, England: The MIT Press.

Ambang, T. (2012). Progress and the challenges of implementing PNG Vision 2050: Reflections from Human Development Index ranking for 2011-2012. Contemporary PNG Studies, 17, 83-93.

Anoser, K. S. (2013). The Evolution of Benefit Sharing Agreement in Papua New Guinea: What are the Lessons Learnt and What are the Prospects For the Future. (Masters), Massey University, New Zealand.

ANZ Bank. (2013). Bold Thinking: Imagining PNG in the Asian Century. Retrieved from PNG http://media.corporate-ir.net/media files/irol/24/248677/insight/ANZ PDF 02.pdf

Aopi, G. (2017). Oil Search contribution to long term sustainability in PNG. Paper presented at the Petroleum and Energy Summit Port Moresby, PNG.

http://www.thecwcgroup.com/speakerpapers/

APERC. (2007). A Quest For Energy Security In The 21st Century: Resources and Constraints. Retrieved from http://aperc.ieej.or.jp/file/2010/9/26/APERC_2007_A_Quest_for_Energy_Security.pdf

APERC. (2012). APEC Energy Overview2012. Retrieved from http://aperc.ieej.or.jp/file/2013/6/28/APEC_Energy_Overview_2012.pdf

Armitage, L. (2001). Customary Land Tenure In Papua New Guinea: Status and Prospects. Retrieved from http://dlc.dlib.indiana.edu/dlc/bitstream/handle/10535/589/armitage.pdf

Asian Development Bank. (2015). Papua New Guinea 2016-2020: Country Partnereship Strategy Retrieved from PNG https://www.adb.org/documents/papua-new-guinea-countrypartnership-strategy-2016-2020

Asian Development Bank. (2016). Papua New Guinea: Economy. Asian Development Bank Outlook. Retrieved from http://www.adb.org/countries/papua-new-guinea/economy 
Associated Press. (2017, June 27, 2017). Papua New Guinea votes with corruption and economic woes key. Associated Press. Retrieved from http://wtop.com/elections/2017/06/papuanew-guinea-votes-with-corruption-and-economic-woes-key-2/

Auditor General. (2016). Report of the Auditor-General Part IV 2016 on the Accounts of Public Authorities and Statutory Bodies. PNG: PNG Governance Reporting Portal for Papua New Guinea Retrieved from https://pngiportal.org/directory/report-of-the-auditor-general-partiv-2016-on-the-accounts-of-public-authorities-and-statutory-bodies.

Australia Department of Foreign Affairs and Trade. (2006). Documents on Australian Foreign Policy: Australia and Papua New Guinea 1966-1969. Canberra, Australia: WH Publishing.

Australian Agency for International Development. (2008). Making Land Work. Volume two: Case studies on customary land and development in the Pacific Retrieved from http://dfat.gov.au/about-us/publications/Documents/MLW_VolumeTwo_Intro_Chap.pdf

Australian Agency for International Development. (2011). Effective Governance. Retrieved from Canberra, Australia:

Australian Department of Foreign Affairs and Trade. (2015). Effective Governance. Strategy for Australia's aid investments. Retrieved from Canberra, Australia: http://dfat.gov.au/aboutus/publications/Documents/effective-governance-strategy-for-australias-aidinvestments.pdf

Auty, R. 2002. Sustaining development in mineral economies: the resource curse thesis. Taylor and Francis.

Auty R. (1995). Economic Development and the Resource Curse Thesis. In: Morrissey O., Stewart F. (Eds) Economic and Political Reform in Developing Countries. Palgrave Macmillan, London

Auty, R. (1993). Sustaining Development in Mineral Economies. The Resource Curse Thesis, Routledge.

Avalos, N., Gonzales Stuva, V., Heal, A., Lida, K., \& Okazoe, N. (2015). Papua New Guinea and the Natural Resource Curse. Comparative Economic Studies, 57(2), 345-360. doi:10.1057/ces.2015.1

Awerbuch, S. ( 1995). Market-based IRP: It's easy!!! . The Electricity Journal, 8(8), 50-67.

Baland, J. M., \& Francois, P. (2000). Rent seeking and resource booms. Journal of Development Economics, 61, 527-542.

Ballard, C., \& Banks, G. (2003). Resource Wars: the anthropology of mining. Annual

Review of Anthropology 32, 287-313.

Bamberger, C. S. (2004). IEA The First 30 Years. Paris, France: OECD/IEA.

Bandara, P. M. N. (2016). Corporate Social Responsibility Disclosure Practices in Papua New Guinea. Advances in Economics and Business, 4(4), 63-75.

Banks, G. (2005). Linking resources and conflict the Melanesian way. Pacific

Economic Bulletin 20 (1), 185-191.

Banks, G. (2008). Understanding 'resource conflicts' in Papua New Guinea. Asia

Pacific Viewpoint 49 (1), 23-34.

Barker, P. (2016). PNG's Economy 2016-past, present and future prospects. Retrieved from http://www.inapng.com/pdf_files/PB\%20\%20Mining\%20and\%20Petroleum\%20Conference\%20\%202016\%20\%20Word\%202007. pdf

Barma, N. (2014). The Rentier State at Work: Comparative Experiences of the Resource Curse in East Asia and the Pacific. Asia Pacific Policy Studies. https://onlinelibrary.wiley.com/doi/pdf/10.1002/app5.26

Barma, N., Kaiser, K, Le, T.M, \& Vinuela, L. (2012). Rents to Riches? The Political Economy of Natural Resource-Led Development: World Bank Publications.

Barnett, A. (2014). Political considerations relevant to Energy and Economic Growth. Retrieved from http://thepolicypractice.com/wp-content/uploads/2014/12/Andrew-review-of-PEAof-Energy-in-Africa-EoD HDYr3 09 Nov 2014 PEA Energy-published-version-withlogo.pdf 
Barry, A., Managing Director, ExxonMobile PNG Ltd,. (2017, 28 February ). Creating lasting opportunities for Papua New Guinea. Paper presented at the Papua New Guinea Petroleum \& Energy Summit, Port Moresby, PNG.

Batten, A. (2011). Aid and Oil in Papua New Guinea: Implications for the Financing of Service Delivery.

Bazeley, P. (2007). Qualitative data analysis with Nvivo. Los Angeles: Sage Publications.

Bazilian, M., and Fabien Roques. . (2009). Introduction: Analytical Approaches to Quantify and Value Fuel Mix Diversity from: Analytical Methods for Energy Diversity \& Security Portfolio Optimization in the Energy Sector: A Tribute to the work of Dr Shimon Awerbuch. ScienceDirect, 12.

Benn, H. (2 February 2006). "Speech to the Royal African Society by the United Kingdom Secretary of State for International Development". In D. Hudson, Leftwich, Adrian (Ed.), From Political Economy to Political Analysis. Birmingham, UK.: The Developmental Leadership Program (DLP), International Development Department, School of Government and Society, College of Social Sciences, University of Birmingham.

Berg, B. L. (2009). Qualitative research methods for the social sciences (7th ed.. ed.). Boston: Allyn \& Bacon.

Bernard. HR. (1998). Research methods in cultural anthropology: Saga Publications

Bhattacharyya, S., \& Hodler, R. (2010). Do Natural Resource Revenues Hinder Financial Development? The role of political Institutions. IDEAS Working Paper Series from RePEC.

Bird, R. (2008). Tax Challenges Facing Developing Countries. Working Paper Retrieved from https://papers.ssrn.com/sol3/papers.cfm?abstract $\mathrm{id}=1114084$

Blades, J. (2016a, 2/09/2017). Heat on PNG PM in and outside parliament. Retrieved from http://www.radionz.co.nz/international/pacific-news/299902/heat-on-png-pm-in-andoutside-parliament

Blades, J. (2016b, 5/09/2017). PNG government keen to resolve LNG dispute. Retrieved from http://www.radionz.co.nz/international/pacific-news/311169/png-government-keen-toresolve-lng-dispute

Blades, J. (2017a, 2/09/2017). Papua New Guinea's economy has 'fallen off a cliff'. Retrieved from http://www.radionz.co.nz/international/pacific-news/328033/papua-new-guinea'seconomy-has-'fallen-off-a-cliff'

Blades, J. (2017b, 2/09/2017). PNG budget blowout from bad to worse. Retrieved from http://www.radionz.co.nz/international/pacific-news/336363/png-budget-blowout-frombad-to-worse

Blades, J. (2017c, Sunday, 8/06/2017). PNG Treasurer: Economy Under Huge Strain, Some Things Have To Change. Retrieved from http://www.pireport.org/articles/2017/08/06/png-treasurer-economy-under-huge-strainsome-things-have-change

Boddy-Evans, A. (2017). The Complete Story Behind Powerful Political Institutions: How They Impact Law, Economy and Culture. Retrieved from https://www.thoughtco.com/political-institutions-44026

Bohi, D. R., A Toman, Michael. (2011). The Economics of Energy Security: Springer.

Bollen, J., Sebastiaan, H, \& Van der Zwaan, B. (2010). An integrated assessment of climate change, air pollution, and energy security policy. Energy Policy, 38(8), 4021-4030.

Bowen, G. A. (2009). Document analysis as a qualitative research method. Qualitative Research Journal, 9(2), 27-40.

Brown, O., \& Keating, M. (2015). Addressing Natural Resource Conflicts Working Towards More Effective Resolution of National and Sub-National Resource Disputes Energy, Environment and Resources, (June). Retrieved from https://www.chathamhouse.org/sites/files/chathamhouse/field/field_document/20150619A ddressingConflictResourcesBrownKeating.pdf

Bustnesli, Y. (2017). The Oil and Gas Review: Norway (S. C. B Ed. 5 ed.): Law Business Ltd

Butler, R., \& Lavery, L, . (2012). Introduction to NVivo 10: working with Data. Retrieved from http://academic-consulting.co.nz/ 
Butlera, C., Parkhillb. K.A. , \& Luzeckaa. P. (2018). Rethinking energy demand governance: Exploring impact beyond 'energy' policy. Energy Research \& Social Science, 36(70-78).

Buzan, B., Wæver, O, \& De Wilde, J. (1998). Security: a new framework for analysis: Lynne Rienner Publishers.

Callan, M. (2013, 13 March 2013). What do big miners contribute to Papua New Guinea's development? Retrieved from http://devpolicy.org/what-do-big-miners-contribute-topapua-new-guineas-development-20130320-2/

Campbell, C. J., \& Laherrère, J.H. (2012). The end of cheap oil. Scientific American, 278(3), 7883.

Chambers, M. (2016). PNG dispute hasn't hit LNG project: ExxonMobil. Retrieved from http://www.theaustralian.com.au/business/mining-energy/png-dispute-hasnt-hit-lngproject-exxonmobil/news-story/f7deeab29cb828c5cdc821f22357f7fe

Chand, S. (2015). Papua New Guinea Sovereign Wealth Fund: The efficacy of the withdrawal formula. Retrieved from http://www.nri.org.pg/images/Downloads/Publications/2015 publications/Issues paper 1 7_PNGs_SWF_the_efficacy_of_the_withdrawal_formula.pdf

Chandler, J. (2018 May). Papua New Guinea's resource curse. Retrieved from https://www.themonthly.com.au/issue/2018/may/1525096800/jo-chandler/papua-newguinea-s-resource-curse

Cheon, A., \& Urpelainen, J. (2014). Escaping Oil's Stranglehold When Do States Invest in Energy Security? . Journal of Conflict Resolution, 59(6), 953-983.

Cherp, A., \& Jewell, J. (2013). Energy security assessment framework and three case-studies. International Handbook of Energy Security. Cheltenham Glos, UK: Edward Elgar.

Cherp, A., Adenikinju, A, Goldthau, A, Hughes, L, Jewell, J, Olshanskaya, M, Jansen, J, Ricardo, S.R, \& Vakulenko, S. (2012). Energy and security. Global Energy Assessment: Toward a Sustainable Future. Retrieved from http://portal.research.lu.se/ws/files/5735037/4239056.pdf

Cherp, A., \& Jewell, J. (2011). The three perspectives on energy security: intellectual history, disciplinary roots and the potential for integration. Current Opinion in Environmental Sustainability, 3(4), 202-212. doi:10.1016/j.cosust.2011.07.001

Cherp, A., \& Jewell, J. (2014). The concept of energy security: Beyond the four As. Energy Policy, 75, 415-421. doi:10.1016/j.enpol.2014.09.005

Cherp, A., Mukhtarov, Farhad. (2014). Energy Security Retrieved from https://www.researchgate.net/publication/269687401

Chester, L. (2010). Conceptualising energy security and making explicit its polysemic nature. Energy Policy, 38(2), 887-895. doi:10.1016/j.enpol.2009.10.039

Cohena, G., Frederick, J, \& Prakash, L. (2011). Measuring energy security: Trends in the diversification of oil and natural gas supplies. Energy Policy, 39(9), 4860-4869.

Cohil, W. (2017, 21 Dec 2017). Too many parliamentary committees in PNG Parliament. Retrieved from http://www.devpolicy.org/too-many-committees-png-parliament$20171221 /$

Colin, W. (2014, 13 January 2014). Without Fear or Favour? O'Neill's District Authorities to Build Capacity and Consolidate MP Powers in PNG. Retrieved from http://devpolicy.org/without-fear-or-favour-oneills-district-authorities-to-build-capacityand-consolidate-mp-powers-in-png-20140113/

Collier, P., \& Hoeffler, A. (2005). Resource Rents, Governance, and Conflict. Journal of Conflict Resolution, 49(4), 625-633.

Collier, R. (2006). "Venezuela's Oil Wealth Funds Gusher of Anti-Poverty Projects.” San Francisco Chronicle (October 2).

Commonwealth of Australia. (2009). National Energy Security Assessment. Retrieved from https://www.energy.gov.au/sites/g/files/net3411/f/national-energy-security-assessment2009.pdf

Creswell, J. (2003). Research design: qualitative, quantitative, and mixed methods approaches (2nd ed.. ed.). Thousand Oaks, Calif.: Sage Publications. 
Creswell, J. (2014). Research design: qualitative, quantitative, and mixed method approaches (Fourth edition, international student edition.. ed.): Los Angeles, Calif.: Sage.

Creswell, J., \& Race, R. (1999). Qualitative inquiry and research design: choosing among five traditions. 41, 236-237.

Crotty, M. (1998). The foundations of social research: meaning and perspective in the research process. Thousands Oaks, Calif: Saga.

CwC. (2018). LNG Word News: The Industry's New Terminal Retrieved from https://www.lngworldnews.com/picture-of-the-day-tanker-at-png-lng-terminal/

D-EITI. (2016). Implementation of the EITI in G7, EU and OECD countries. Retrieved from https://eiti.org/sites/default/files/documents/study-on-eiti-implementation-in-oecdcountries.pdf

Demsetz, H. (1967). "Toward a Theory of Property Rights." The American Economic Review 57 (2). The American Economic Association: 347-59.

---2002. "Toward a Theory of Property Rights II: The Competition Between Private and Collective Ownership." The Journal of Legal Studies 31 (S2). The University of Chicago Press: S653-S672.

---2009. “Toward a Theory of Property Rights." In Commons and Anticommons. Volume 2, 12133. Unlisted: An Elgar Reference Collection. Economic Approaches to Law, vol. 26. Cheltenham, U.K.; Northampton, Mass.: Elgar.

Denzin, N., \& Lincoln, YS. (2005). The handbook of qualitative research (3 ed.). London Sage.

Denzin, N., \& Lincoln, YS. (2011). Handbook of qualitative research (4 ed.). London Sage.

Denzin, N., \& Lincoln, YS (Ed.) (2000). Handbook of Qualitative Research (2 ed.). London: Saga.

Denzin, N. K., \& Lincoln, Y. S (Ed.) (2008). Strategies of Qualitative Inquiry (3 ed.). Thousand Oaks, CA: Saga.

Denzin, N. K., \& Lincoln, Y.S (Ed.) (1994). Handbook of qualitative research (1 ed.). London: Saga.

Denzin, N. K., \& Lincoln, Y.S (Ed.) (1998). Strategies of Qualitative Inquiry. London: Sage.

Department of National Planning and Monitoring. (2010). Papua New Guinea Development Strategic Plan 2030. Port Moresby, PNG: Government Printing.

Department of National Planning and Monitoring. (2015). National Strategy for Responsible Sustainable Development for Papua New Guinea (STaRS). Port Moresby, PNG: Government Printing.

Deszcz, A., \& Ladbury, R. (2006). Petroleum Projects in Papua New Guinea. Journal of Energy \&amp; Natural Resources Law, 24(1), 104-119. doi:10.1080/02646811.2006.11433427

Di John, J. (2011). Is There Really a Resource Curse? A Critical Survey of Theory and Evidence. Global Governance, 17, 167-184.

Dobson, E., Carreras, B.A, Lynch, V.E, \& Newman, D.E. (2007). Complex systems analysis of series of blackouts: Cascading failure, critical points, and self-organization. Chaos: An Interdisciplinary Journal of Nonlinear Science, 17 (2), 026103.

Downs, E. S. (1999). The Chinese energy security debate. The China Quarterly, 177, 21-41.

Dyer, H., \& Julia, M.T. (2013). Introduciton from: International Handbook of Energy Security Retrieved from https://www.e-elgar.com/shop/eep/preview/book/isbn/9781781007907/

Eisenhardt, K. (1989). Building Theories from Case Study Research. The Academy of Management Review, 14(4), 532-550.

Eisenhardt, K. (Ed.) (2002). Building theories from case study research. Thousand Oaks, London, New Delhi: Sage Publications.

Encyclopedia. (2015). https://www.tokpisin.info/land-ownership-papua-new-guinea/.

EMTV (Producer). (2018, 7 June 2018). Ombudsman Commission: Supreme Court Reference to be filed over validity of PMMR Act 2017. Retrieved from

http://www.emtv.com.pg/ombudsman-commission-supreme-court-reference-to-be-filedover-validity-of-pmmr-act-2017/

EY. (2014). Managing bribery and corruption risks in the oil and gas industry. Retrieved from http://www.ey.com/Publication/vwLUAssets/EY-Managing-bribery-and-corruption-risk- 
in-the-oil-and-gas-industry/\$FILE/EY-Managing-bribery-and-corruption-risk-in-the-oiland-gas-industry.pdf

Falon, J. (2015). State Owned Enterprises in Papua New Guinea: Public Policies and Performance. Retrieved from http://www.economicinsights.com.au/reports/EconomicInsightsPNGSOEsNRIReport.pdf

Farrell, A. E., Zerriffi, H, \& Dowlatabadi, H. (2004). Energy infrastructure and security. Review of Environment and Resources, 29, 421-469.

Feak, C. B., Irwin, V, \& swales J.M. (2009). Telling a research story: writing a literature review. Retrieved from doi:http://catdir.loc.gov/catdir/enhancements/fy1001/2009281625-d.html

Fernandes, C. P., \& Ferreira, R.T (Ed.) (2017). Geopolitics of Energy and Energy Security. Portugal Idn cadernos

Filer, C. (1997). Compensation, rent and power in Papua New Guinea. In: Toft, S. (Ed.), Compensation for Resource Development in Papua New Guinea. The Australian National University, Canberra, pp. 157-189.

Filer, C., \& Imbun, B. (2009). A Short History of Mineral Development Policies in Papua New Guinea, 1979-2002. In R. J. May (Ed.), Policy Making and Implementation: Studies from Papua New Guinea (Vol. 5). Canberra, Australia: ANU e-Press.

Flanagan, P. (2015). PNG's frightening fiscal figures. Retrieved from http://devpolicy.org/pngsfrightening-fiscal-figures-20150805/

Flanagan, P. (2016, 15/09/2016). PNG'S Economic History Since Independence. Retrieved from http://pngeconomics.org/?p=281

Flanagan, P., \& Fletcher, L. (2018). Double or Nothing: The Broken Promise of PNG LNG. Retrieved from http://www.jubileeaustralia.org/latest-news/new-jubilee-report-shows-thatefic-funded-png-lng-project-has-hurt-png

Fletcher, L., Webb, A, Hickie, S, \& Otterman, M. (2013). PIPE DREAMS - The PNG LNG Project and the Future Hopes of a Nation. Retrieved from www.jubileeaustralia.org/LiteratureRetrieve.aspx? ID $=112463$

Fontaine, G. (2011). The effects of governance modes on the energy matrix of Andean countries. Energy Policy, 39(5), 2888-2898. doi:10.1016/j.enpol.2011.02.064

Froggatt, A., Kuzemko, C, Rouhaud, E, Mitchell, C, Watson, J, \& Whiting, J. (2013). The energy security-climate nexus and the environment. New Challenges in Energy Security: the UK in a Multipolar World. Basingstoke: Palgrave Macmillan.

Frynas, J. G. (2010). Corporate Social Responsibility and Societal Governance: Lessons from Transparency in the Oil and Gas Sector. Journal of Business Ethics, 93, 163-179.

Galaz, V. B., Folke, F, Nilsson, C, \& Olsson, P. (2012). Global environmental governance and planetary boundaries: An introduction (Vol. 81, pp. 1-3).

Gapromas Problem Management Services. (2014). A Review Report of the Consultative Implementation and Monitoring Council. Retrieved from http://www.cimcpng.net/images/reviewreport.pdf

Garnaut, J. (2011, 5/09/2017). PNG chiefs talk of civil unrest over unpopular Australian bank deal. Retrieved from http://www.smh.com.au/business/world-business/well-turn-off-thetaps-png-chiefs-challenge-australian-bank-deal-20151009-gk58dq.html

George, M. (2013). Exploring the definitions and practices of corporate social responsibility (CSR) from a corporate perspective: A case of the Inter Oil Corporation in Papua New Guinea. (Masters ), Waikato University New Zealand Retrieved from http://researchcommons. waikato.ac.nz/.

Gerring, J. (Ed.) (2007). Case study research: principles and practices. New York: Cambridge University Press.

Gibbs, P. (2006). Papua New Guinea. In M. Ernst (Ed.), Globalization and the Re-Shaping of Christianity in the Paciflc Islands. Suva, Fiji: The Pacific Theological College. Retrieved from http://www.philipgibbs.org/pdfs/PNG\%20globalization.pdf.

Gilad, S. (2018). Institution - POLITICAL SCIENCE: Encyclopaedia Britannica.

Gilberthorpe, E., \& Banks, G. (2012). Development on whose terms?: CSR discourse and social realities in Papua New Guinea's extractive industries sector. Resources Policy, 37(2), 185193. doi:10.1016/j.resourpol.2011.09.005 
Glaskin, K., \& Weiner, J.F (Ed.) (2007). Customary Land Tenure and Registration in Australia and Papua New Guinea: Anthropological Perspectives (Vol. 3): ANU Press

Gnansounou, E. (2009). Energy Transition and Security of Supply: OECD Countries. Security and Peace, Vol. 27, No. 4, 27(4), 209-214.

Goldthau, A. (2008). Rhetoric versus reality: Russian threats to European energy supply. Energy Policy, 32(6), 686-692.

Goldthau, A., \& Witte, J.M. (2010). Chapter 1. The Role of Rules and Institutions in Global Energy: An IntroductionGlobal Energy Governance: The New Rules of the Game:

Brookings Institution Press. Retrieved from https://www.brookings.edu/wpcontent/uploads/2016/07/globalenergygovernance chapter.pdf.

Government of Papua New Guinea. (2015a). 2015 National Budget. PNG: Government Printing.

Government of Papua New Guinea. (2016b). Final Budget Outcome 2016. PNG Government Priniting Retrieved from

http://www.treasury.gov.pg/html/national budget/files/2013/budget documents/Related\% 20Budget\%20Documents/2016\%20FBO\%20-\%20FINAL.pdf.

Government of Papua New Guinea. (2017a). 2017 National Budget Speech by Treasruer PNG:

Treasury Retrieved from

http://www.treasury.gov.pg/html/national budget/files/2017/2017\%20Treasurer's\%20Bud get\%20Speech.pdf.

Government of Papua New Guinea. (2017b). Public Money Management Regularisation Bill 2017 Explanatory Memorandum PNG Treasury Retrieved from http://www.treasury.gov.pg/html/national budget/files/2018/Tax\%20Bill/Public\%20Fund s\%20Management\%20Regularization\%20Bill\%20\%20Explanatory\%20Memorandum.pdf.

Government of Papua New Guinea. (2010). Papua New Guinea Vision 2050. Papua New Guinea: Papua New Guinea Government Printing.

Government of Papua New Guinea. (2013a). Papua New Guinea Defence White Paper. PNG: Government Printing.

Government of Papua New Guinea. (2013b). Papua New Guinea National Security Policy. PNG: Government Printing.

Government of Papua New Guinea. (2015f). Papua New Guinea National Energy Policy 20162020. PNG: Department of Petroleum and Energy.

Government of Papua New Guinea and UN in Papua New Guinea. (2015). POST-2015 DEVELOPMENT AGENDA COUNTRY CONSULTATIONS. PNG: Government Printing Retrieved from http://www.pg.undp.org/content/dam/papua new guinea/docs/MDG/UNDP PG The\%20 future\%20We\%20Want\%202015.pdf.

Gracceva, F., \& Zeniewski, P. (2014). A systemic approach to assessing energy security in a lowcarbon EU energy system. Applied Energy, 123, 335-348.

Graue, C., Pacific Beat, (Producer). (2017, 5/09/2017). Hela 'no Bougainville', says former PNG defence force chief Singirok. Retrieved from https://asiapacificreport.nz/2017/01/12/helano-bougainville-says-former-png-defence-force-chief-singirok/

Grave, K., Paulus, M, \& Lindenberger, D. (2012). A method for estimating security of electricity supply from intermittent sources: scenarios for Germany until 2030. Energy Policy, 46, 193-202.

Grindle, M. S. (2004). Good enough governance: poverty reduction and reform in developing countries. Development Policy, 17(4), 525-548.

Grindle, M. S. (2007). Good enough governance revisited. . Development Policy, 25(5), 553-574.

Gupta, E. (2008). Oil vulnerability index of oil-importing countries. Energy Policy, 36, 11951211.

Haley, N., May, R.J. (Eds.) (2007). Conflict and Resource Development in the Southern Highlands of Papua New Guinea. ANU E Press.

Hambly, L., \& Morgan, M. G. (2008). Political Parties in the Pacific Islands: Canberra: ANU E Press. 
Hancock, K. J., \& Vivoda, V. (2014). International political economy: A field born of the OPEC crisis returns to its energy roots $1,206-216$. Retrieved from

https://doi.org/10.1016/J.ERSS.2014.03.017

Hassall, G. (2011). The Parliamentary Committee System In Papua New Guinea, 1975-1997. CLJP-RJP(17).

Hayward-Jones, J. (2016). In Prime Minister O'Neill's Press Club address, more candour on social and economic issues needed. Retrieved from https://www.lowyinstitute.org/theinterpreter/prime-minister-oneills-press-club-address-more-candour-social-and-economicissues

Hayward-Jones, J. (2017). Changing Geopolitical Dynamics For Papua New Guinea. Png Country Assessment. Retrieved from http://interactives.lowyinstitute.org/publications/PNGin2017/downloads/HaywardJones_Geopolitics.pdf

Helm, D. (2002). Energy policy: security of supply, sustainability and competition. Energy Policy, 30(3), 173-184.

Hill, C., \& Fletcher, L (Eds). (2018). Growing Bougainville's Future. Jubilee

Australia. https://www.jubileeaustralia.org/helpful-resources/publications

Holden, S. (2013). Avoiding the resource curse the case Norway. Energy Policy, 63, 870-876.

Howell, B.E, Potgieter, P.H., \& Sofe, R. (2018) Between the Conception and the Action: Implementing Papua New Guinea's State-Owned Enterprise Policy.

Howes, S. (2017a, November 10, 2016). Angau Hospital, and PNG's 2017 budget. Retrieved from http://devpolicy.org/angau-hospital-stories-pngs-2017-budget/

Howes, S. (2017b). Papua New Guinea 2018 budget fails to solve revenue crisis. Retrieved from http://www.devpolicy.org/png-budget-20171129/

Howes, S., \& Rohan, F. (2016, 12 September 2016). How did PNG spend the resource boom? Retrieved from http://devpolicy.org/how-did-png-spend-the-resources-boom-20160912/

Hualupmomi, F. (2012). Geopolitics of Geopolitics of Sino-PNG-US in Western Pacific in 21 st Century. An IPE State-centric Perspective. Masters Thesis. School of Law, Institute of International Studies. Jilin University.

Hudson, D., \& Leftwich, A. (2014, 29 June). From Political Economy to Political Analysis. Research Paper. (25). Birmingham, UK.

Hughes, L., \& Lipscy, P.Y. (2013). The politics of energy. Annual Review of Political Science, $16,449-469$.

Hughes, L., \& Rudolph, J. (2011). Future world oil production: growth, plateau, or peak? . Current Opinion in Environmental Sustainability, 3(4), 225-234.

Hunter, T. (2010). Legal Regulatory Framework for Sustainable Extraction of Australian Offshore Petroleum Resources (Ph.D), University of Bergen Retrieved from http://epublications.bond.edu.au/cgi/viewcontent.cgi?article=1353\&context=law_pubs

Hydén, G., Court, J, \& Mease, K. (2004). Making Sense of Governance: Empirical Evidence from 16 Developing Countries. Retrieved from https://www.odi.org/sites/odi.org.uk/files/odiassets/publications-opinion-files/4092.pdf

Ikenberry, G. (1986). The Irony of State Strength: Comparative Responses to the Oil Shocks in the 1970s. International Organization, 40(1), 105-137.

Ila'ava, S. (2014a). Papua New Guinea's Domestic Security: Literature Review (11). Retrieved from https://pngnri.org/wp-content/uploads/2016/06/IP11-201214-Ilaava-Papua-NewGuineas-Domestic-Security.pdf

Ila'ava, S. (2014b). Papua New Guinea's International Security: Literature Review (12). Retrieved from https://pngnri.org/wp-content/uploads/2016/06/IP12-201412-IlaavaPapua-New-Guineas-International-Security.pdf

Imbun, B. (2006). Multinational mining and petroleum companies' perceptions of the policy framework in Papua New Guinea. Pacific Economic Bulletin, 21(1), 225-242.

International Energy Agency. (2010). Energy Security and Climate Policy Assessing Interactions. Retrieved from https://www.iea.org/publications/freepublications/publication/energy security climate po licy.pdf 
International Energy Agency. (2011). Energy Policies of IEA Countries: Norway Retrieved from https://webstore.iea.org/energy-policies-of-iea-countries-norway-2017-review

International Energy Agency. (2015). World Energy Trends. Execerpt from: Energy Balnces of Non-OECD Countries Retrieved from https://www.iea.org/publications/freepublications/publication/WorldTrends NonOECD c ountries2015.pdf

International Energy Agency. (2017). World Energy Outlook. Retrieved from https://www.oecdilibrary.org/energy/world-energy-outlook-2017_weo-2017-en

IRENA, (2013). Renewable Energy and Jobs.

https://www.irena.org//media/Files/IRENA/Agency/Publication/2013/rejobs.pdf

Jaffe, A. M., Klare, M.T, \& Elhefnawy, N. (2008). The Impending Oil Shock: An Exchange. Survival, 50(4), 61-82.

Jain, A. (2001). Corruption: A Review, Journal of Economic Surveys, 15 (1): 71-121.

James, D. (2018, March 27). Business Advantage PNG. Retrieved June 5, 2019, from https://www.businessadvantagepng.com/mrdc-has-wide-mandate-says-md/

Jensen, N., \& Wantchekon, L. (2004). Resource wealth and political regimes in Africa. Comparative Political Studies, 37(7), 816.

Jewell, J. (2011). The IEA model of short-term energy security (MOSES): primary energy sources and secondary fuels. Retrieved from http://www.iea.org/publications/freepublications/publication/name-20557-en.html.

Jewell, J. (2013). Energy security and climate change mitigation: The interaction in long-term global scenarios. (Ph.D), Central European University. Retrieved from http://www.etd.ceu.hu/2013/jewell jessica.pdf

Jewell, J., Cherp, A, \& Riahi, K. (2014). Energy security under de-carbonization scenarios: An assessment framework and evaluation under different technology and policy choices. Energy Policy 65, 743-760

Johansson, B. (2013). A broadened typology on energy and security. Energy, 53, 199.

Kaldor, M. (1999). New Wars: Organized Violence in a Global Era. Cambridge: Polity Press.

Johnston, M. (2005). Syndromes of Corruption: Wealth, Power, and Democracy. Cambridge: CUP.

Kantha, S. (2008). Contemporary Pacific: Melanesia in Review: Issues and Events, 2008: Papua New Guinea. Retrieved from http://www.pireport.org/articles/2009/09/30/contemporarypacific-melanesia-review-issues-and-events-2008-papua-new-guinea

Kaplan, R. (1994). The Coming Anarchy: Atlantic Monthly.

Kari, S. S. (2005). The Origin and Setting of the National Goals and Directive Principles in the Setting and Writing of the Constitution. (PhD), Queensland University of Technology Australia Retrieved from https://eprints.qut.edu.au/16071/1/Sam Kari Thesis.pdf

Karl, T. L. (1997). The paradox of plenty: Oil booms and petro-states. Berkley: University of California Press.

Kavanamur, D. (2003). Building A Nation In Papua New Guinea: Views Of The Postindependence Generation. Canberra: Canberra : Pandanus Books.

Kavanamur, D., \& Turner, M. (2009). Explaining Public Sector Reform Failure: Papua New Guinea 1975-2001 Vol. 5. Y. J. May (Ed.) Policy Making and Implementation: Studies from Papua New Guinea Retrieved from www. oapen.org $/$ download?type $=$ document $\&$ docid $=459445$

Kendell, J. M. (1998). Measures of oil import dependence. Retrieved from http://www. eia. doe. gov/oiaf/archive/issues98/oimport. html

Kenneth, G. (2017a, 5 Oct 2017). I was not sacked. Post Courier

Kenneth, G. (2017b, 4 Oct). MD sacked for K4m pay hike. Post Courier

Kern, F., Kuzemko, C, \& Mitchell, C. (2013 ). Measuring and explaining policy paradigm change: The case of UK energy policy. Policy \& Politics, 42(2).

Kessels, J. R., Bakker, S, \& Wetzelaer, B. (2008). Energy Security and the Role of Coal. Retrieved from paris: https://www.ecn.nl/publications/bs/2008/ECN-B--08-010

Khan, M. Rent-Seeking as Process. In Khan M.; Jomo, K.S. (Eds) Rents, Rent-Seeking and Economic Development: Theory and Evidence in Asia. Cambridge: CUP. 2000a. 
Khan, M. Rents, Efficiency and Growth. In Khan M.; Jomo, K.S. (Eds). Rents, Rent-Seeking and Economic Development: Theory and Evidence in Asia. Cambridge: CUP. $2000 \mathrm{~b}$.

Khan, M. The New Political Economy of Corruption. In Fine, B.; Lapavistas, C.; Pincus, J. Development Policy in the Twenty-First Century: Beyond the Washington Consensus. London: Routledge. 2001.

Khan, M. State Failure in Developing Countries and Institutional Reform Strategies'. In Tungodden, B.; Stern, N.; Kolstad, I. (Eds). Towards Pro-Poor Policies: Aid Institutions and Globalization. Annual World Bank Conference on Development Economics, Europe 2003. Washington, DC: OUP and World Bank. 2004.

Khan, M. Governance, Economic Growth and Development since the 1960s: Background Paper for the World Economic and Social Survey 2006. DESA Working Paper No. 54. New York: UN. 2006.

Khan, M. (2007). Governance, Economic Growth and Development since the 1960s. DESA Working Paper No. 54. New York: UN.

Khan, M. (2010). Political Settlements and the Governance of Growth-Enhancing Institutions. DFID Research Paper on Governance for Growth. London: School of Oriental and African Studies, University of London.

Kirk, G. (Ed.) (1982). Schumacher on energy: speeches and writings of E.F. Schumacher London: London.

Kjær, A. M. (2004). Governance / Anne Mette Kjoer. Malden, MA: Malden, MA : Polity/Blackwell.

Klare, M. (2001a). The geopolitics of war. The Nation, 273(14), 11-15.

Klare, M. (2001b). The new geography of conflict. Foreign Affairs, 80(3), 49-61.

Klare, M. (2002). Resource wars: The new landscape of global conflict. New York: Henry Holt.

Klare, M. (2004a). Blood and oil: the dangers and consequences of America's growing petroleum dependency (1st ed.. ed.). New York: New York: Metropolitan Books.

Klare, M. (2004b). Geopolitics Reborn: The Global Struggle over Oil and Gas Pipelines. Current History, 103(677), 428-429,431-433.

Klare, M. (2009). There will be blood: political violence, regional warfare, and the risk of greatpower conflict over contested energy resources. . In G. Luft \& A. Korin (Eds.), Energy security challenges for the 21st century. A reference handbook (pp. 44-65). Santa Barbara, California: Praeger Security International

Kobayashi, Y. V. A. (2015). 'Oil Stockpiling Development in Southeast Asia', in Oil Stockpiling and Emergency Response Cooperation of East Asia. Retrieved from http://www.eria.org/RPR_FY2014_No.32_Chapter_2.pdf

Koim, S., \& Howes, S. (2016, December 16). DevPOLICYBLOG. Retrieved June 4, 2019, from http://www.devpolicy.org/png-lng-landowner-royalties-long-20161216/

Kongoi, S.-N. (2017). National Content Paper presented at the Petroleum and Energy Summit http://www.thecwcgroup.com/speakerpapers/

Konte, M. (2013). A curse or a blessing? Natural resources in a multiple growth regimes analysis. Applied Economics, 45(26), 3760-3769. doi:10.1080/00036846.2012.730137

Krasner, S. (1978). Defending the national interest: Raw materials investments and U.S. foreign policy. Princeton, N.J: Princeton University Press.

Kruyt, B., Vuuren, D.P.V, De Vries, H. J. M, \& Groenenberg, H. (2009). Indicators for energy security. Energy Policy, 37(6), 2166-2181.

Kuik, O. J., Bastos, L.M, \& Joyeeta, G. (2011). Energy security in a developing world. Focus Article, 2.

Kumul Consolidated Holdings. (2019). https://www.kch.com.pg/about/

Kumul Petroleum Holdings. (2018). http://kumulpetroleum.com/

Kumul Petroleum Holdings Limited. (2015). Kumul Petroleum Signs MOU with PNG Power Limited: Develop Solutions to Domestic Energy Demand.

http://kumulpetroleum.com/news-article/kumul-petroleum-signs-mou-with-png-powerlimited-develop-solutions-to-domestic-energy-demand/ 
Kumul Petroleum Holdings Ltd. (2016). Kumul Petroleum To Underwrite the Petroleum \& Energy Conference (PNG). Retrieved from http://kumulpetroleum.com/pressrelease/npcp-to-underwrite-the-petroleum-energy-conference-png/

Kuwimb, M. (1997). An examination of Papua New Guinea's petroleum law and policy. (Masters), Wollongong University, Wollongong, Australia.

Kuwimb, M. (2010). A Critical Study of the Resource Curse Thesis and The Experience of Papua New Guinea. (Doctor of Philosophy), James Cook University, Cairns, Australia. Retrieved from http://researchonline.jcu.edu.au/11667/

Kuzemko, C. (2014). Ideas, power and change: explaining EU-Russia energy relations. Journal of European Public Policy, 21(1), 58-75.

Labaree, R. V. The risk of 'going observationalist': negotiating the hidden dilemmas of being an insider participant observer. Qualitative Research, 2(1), 97-122.

Larsson, R. L. (2006). Sweden and the NEGP: A Pilot Study of the North European Gas Pipeline and Sweden's Dependence on Russian Energy. Retrieved from https://www.foi.se/reportsearch/pdf?fileName...1341-4861-925e-aa21573dae33...

Lasslett, K. (2014). State crime on the margins of Empire: Rio Tinto, the war on Bougainville and resistance to mining. London: Pluto Press.

Le Billion, P. (2001). The political ecology of war: natural resources and armed conflicts. Political Geography 20, 561-584.

Lecompte, M. (2000). Analyzing qualitative data. Theory into Practice, 39(3), 146.

Lesage, D., Graff, T.v.D, \& Westphal, K (Ed.) (2010). Global energy governance in a multipolar world England Ashgate.

Leung, G. C. K. (2011). China's energy security: Perception and reality. Energy Policy, 39(3), 1330-1337.

Levantis, T., \& Sanida, O.O. (2015) Mid-year review and forecast of the PNG economy. Discussion Paper: Vol. 144. PNG: National Research Institute.

Levi, M. A. (June 2010). Working Paper: Energy Security An Agenda for Research. New York, US: CFR Retrieved from www.cfr.org/content/publications/attachments/Energy_Security_Workshop_Paper.pdf.

Lewis, R. (2004). NVivo 2.0 and ATLAS.ti 5.0: a comparative review of two popular qualitative data- analysis programs. Field methods, 16(4), 439-463.

Lilliestam, J., \& Saskia, E. (2011). Energy security and renewable electricity trade: Will Desertec make Europe vulnerable to the 'energy weapon?'. Energy Policy, 39(6), 3380-3391.

LNG World News staff. (2014, 16 May 2014). Picture of the Day: Tanker at PNG LNG Terminal. Retrieved from https://www.lngworldnews.com/picture-of-the-day-tanker-at-png-lngterminal/

LoopPNG. (2017, 1 June 2018). Hearing commence on reference relating to UBS loan Retrieved from http://www.looppng.com/png-news/hearing-commence-reference-relating-ubs-loan$\underline{52641}$

Lovins, A. B., \& Lovins, H.L. (1982). Brittle power: Brick House Publishing Company.

Luft, G., \& Korin, A. (Eds.). (2009). Energy security. In the eyes of the beholder: Energy security challenges for the 21 st century. A reference handbook, . Santa Barbara, California Pr'aeger Security International

Main, M., \& Fletcher, L. (2018). On shaky ground: PNG LNG and the consequences of development failure. Jubilee Australia. https://www.jubileeaustralia.org/helpfulresources/publications

Main, M. (2017, March 9, 2017). Papua New Guinea gets a dose of the resource curse as ExxonMobil's natural gas project foments unrest. Retrieved from https://theconversation.com/papua-new-guinea-gets-a-dose-of-the-resource-curse-asexxonmobils-natural-gas-project-foments-unrest-70780

Manzano, O., \& Roberto, R. (2001). Resource Curse or Debt Overhang? NBER Working Paper Series, 8390. doi:10.3386/w8390

Matui, M. J. (2010). Developing a Corporate Governance Regime For State Owned Enterprises In Papua New Guinea. (Doctor of Philosophy), Waikato, Hamilton, New Zealand. Retrieved from 
http://researchcommons.waikato.ac.nz/bitstream/handle/10289/5169/thesis.pdf;jsessionid= EEF23AEF003FA0BE0F872B3B285995C6? sequence=3

May, J. R. (2004). State and Society in Papua New Guinea: the First Twenty-Five Years. Canberra: ANU E Press.

May, J. R. (1997). Regime Change and Regiem Maintenace in Asia and The Pacific (18). Retrieved from http://pacificinstitute.anu.edu.au/sites/default/files/resourceslinks/PSC_Regime_WP_18.pdf

May, J. R. (2008). Political Parties in Papua New Guinea (H. L. Rich Roland, Morgan G. Michale Ed.). Canberra, Australia: ANU E Express.

McCollum, D. L., Krey, V, Riahi, K, Kolp, P, Grubler, A, Makowski, M, \& Nakicenovic, N. (2013). Climate policies can help resolve energy security and air pollution challenges. Climatic change, 119(2), 479-494.

McNeish, J. A. (2010). World Development Report 2011: Background Paper: Rethinking Resource Conflict. Retrieved from http://web.worldbank.org/archive/website01306/web/pdf/wdr\%20background\%20paper\% 20-\%20mcneish_0.pdf

Micah, B. (2012). Speech by Hon Ben Micah MP Minister for Public Enterprises and State Investments to the Business Advantage Conference Port Moresby, Papua New Guinea Monday September 102012 [Press release]. Retrieved from http://www.businessadvantageinternational.com/PNG-Advantage-2012/Ben-MicahPublic-Enterprises-Minister.pdf

Michael, T. K. (2008). Rising Powers, Shriking Planet: The New Geopolitics of Energy New York: Metropolitan Books.

Migdal, J. S. (1988). Vision and Practice: The Leader, the State, and the Transformation of Society. International Political Science Review/Revue internationale de science politique, 9(1), 23-41.

Miles, M. B., \& Huberman, A.M. (1994a). Qualitative Data Analysis: Thousand Oaks: Sage.

Miles, M. B., \& Huberman, A.M (Ed.) (1994b). Qualitative Data Analysis: An Expanded Sourcebook (2 ed.). London: Saga.

Ministry Of Public Enterprises \& State Investments. 2014. "Principles of State Ownership and Participation in Commercial Activities."

Minnegal, M.,Main M., \&, Dwyer, P. (2018). From business development to protection money: landowners and the PNG LNG project. http://www.devpolicy.org/landowners-png-lng-project20180704/

Mitchell, J. V. (2002a). A new political economy of oil. Quarterly Review of Economics and Finance, 42(2), 251-272. doi:10.1016/S1062-9769(02)00130-8

Mitchell, J. V. (2002b). Renewing Energy Security. London Royal Institute of International Affairs.

Moore, M., \& Putzel, J. (1999). Thinking Strategically about Politics and Poverty. IDS Working Paper 101. Retrieved from http://www.ids.ac.uk/index.cfm?objectID=FA0755E3-50568171-7B8A757CBE2523D4\&pgno $\mathrm{pub}=5 \mathrm{~S}$

Morauta, M. (2011). The theft and waste of public money in Papua New Guinea's Public Enterprises. Retrieved from http://actnowpng.org/content/theft-and-waste-public-moneypapua-new-guineas-public-enterprises

Morauta, M. (2012, 2 January, 2012). Managing the boom in mineral revenue in Papua New Guinea. Retrieved from http://www.eastasiaforum.org/2012/01/02/managing-the-boomin-mineral-revenue-in-papua-new-guinea/

Morey, M., \& Kirsch, L. (2014). Germany's Renewable Energy Experiment: a Made-to-Order Catastrophe. The Electricity Journal, 27(5), 6-20.

Morgan, M. 2005. Cultures of Dominance: Institutional and Cultural Influences on Parliamentary Politics in Melanesia. State Society and Governance in Melanesia Discussion Paper 2005/2. Canberra: Research School of Pacific and Asian Studies, The Australian National University.

Müller, K. S. (2007). Energy Security. London UK: Earthscan. 
Murakami, T., Motokura, M, \& Kutunai, I. (2011). An Analysis of Major Countries' Energy Security Policies and Conditions Retrieved from https://eneken.ieej.or.jp/data/3719.pdf

Nafzinger, W., \& Auvinen, J (1996). Economic Development, Inequality, War and State Violence. World Development, 30, 11.

Narokobi, V. (2016). THE IMPLEMENTATION OF PAPUA NEW GUINEA'S NATIONAL GOALS AND DIRECTIVE PRINCIPLES AND BASIC SOCIAL OBLIGATIONS. (PhD), Victoria University of Wellington, Wellington, New Zealand. Retrieved from http://researcharchive.vuw.ac.nz/xmlui/handle/10063/5030

National Parliament. (2018). Parliament Hansard PNG: National Parliament of Papua New Guinea Retrieved May 2, 2018, from http://www.parliament.gov.pg/hansard.

National Parliament. (2018). Land (Amendment) Act 2018. http://www.parliament.gov.pg. Retrieved June 4, 2019, from http://www.parliament.gov.pg

National Parliament. (2016). About Our Parliament. Retrieved May 2, 2018, from http://www.parliament.gov.pg/about/parliament

Natural Resorce Governance Institute. (2015). The Resource Curse: The Political and Economic Challenges of Natural Resource Wealth. Retrieved from https://resourcegovernance.org/sites/default/files/nrgi_Resource-Curse.pdf

Natural Resorce Governance Institute. (2017). 2017 Resource Governance Index Retrieved from U.K: https://resourcegovernance.org/analysis-tools/publications/2017-resourcegovernance-index

Natural Resorce Governance Institute. (2018a). Retrieved from www.resourcegovernance.org.

Natural Resorce Governance Institute. (2018b). Natural Resource Governance Glossary. Retrieved from https://resourcegovernance.org/analysis-tools/tools/natural-resourcegovernance-glossary

Neale, T. (2003). Historical Overview of Mining in PNG.

Nicholas, I. (2018). KPHL Report to be tabled in Parlt- Abel. Post Courier Retrieved from https://postcourier.com.pg/kphl-report-tabled-parlt-abel/

North, D. C. (1990). A Transaction Cost Theory of Politics. Journal of Theoretical Politics, 2(4), 355-367. https://doi.org/10.1177/0951692890002004001

NRI. (2017, 23/9/2017). Revisiting ' The Oil Search loan: implications for PNG'. Retrieved from https://pngnri.org/revisiting-the-oil-search-loan-implications-for-png/

Nyman, J. (2014). 'Red Storm Ahead': Securitisation of Energy in US-China Relations. Millennium: Journal of International Studies, 43(1), 43-65.

Odhuno, F. (Ed.) (2014). Special Report: Proceedings Of The 2014 Papua New Guinea Tax Review And Research Symposium. PNG: NRI.

Odhuno, F., Ayres, D, Sanida, O, \& Yala, C. (2016). Why the Foreign Currency Crisis in PNG is Almost Entirely Up to the Government to Sort Out. Retrieved from PNG: https://pngnri.org/wp-content/uploads/2016/06/SL9-1-201604-Odhuno-Forex-Crisis.pdf

OECD Nuclear Energy Agency. (2010). The Security of Energy Supply and the Contribution of Nuclear Energy. Retrieved from https://www.oecd-nea.org/ndd/pubs/2010/6358-securityenergy-sup.pdf

Oil-Search. (2014). Oil-Search Annual Report.

https://www.oilsearch.com/_data/assets/pdf_file/0015/1563/2014-Annual-Report-interactiveb4698b29-3629-448c-ab7a-c2823e588e51-0.pdf

Okole, H. (2005). The 'Fluid' Party System of Papua New Guinea. Commonwealth \&amp; Comparative Politics, 43(3), 362-381. doi:10.1080/14662040500304924

Ongwamuhana, K., \& Regan, A. (1991).Ownership of Minerals and Petroleum in Papua New Guinea: The Genesis and Nature of the Legal Controversy. QLD. University Of Technology Law Journal, 7. https://lr.law.qut.edu.au/article/view/345

O'Neill, P., Prime Minister of Papua New Guinea,. (2015, 14 May 2015). ADDRESS BY HON PETER O'NEILL CMG MP, PRIME MINISTER PAPUA NEW GUINEA [Speech ]. Retrieved from https://www.lowyinstitute.org/publications/address-hon-peter-oneill-cmgmp-prime-minister-papua-new-guinea

O’Neil, J. (2016). 'People, Planet, Profits' and Perception Politics: A Necessary Fourth (and Fifth) Bottom Line? Critiquing the Current Triple Bottom Line in the Australian Context. 
In D. Crowther, Seifi Shahla, \& Moyeen Abdul (Ed.), The Goals of Sustainable Development Responsibility and Governance. Singapore Springer Retrieved from https://link.springer.com/content/pdf/10.1007\%2F978-981-10-5047-3.pdf.

Organisation for Economic Co-operation and Development. (2007). OECD Contribution to the United Nations Commission on Sustainable Development 15: Energy For Sustainable

Development. Retrieved from https://www.oecd.org/greengrowth/38509686.pdf

Organisation for Economic Co-operation and Development/International Energy Agency. (2013). World Energy Outlook Retrieved from https://www.iea.org/publications/freepublications/publication/WEO2013.pdf

Orogun, P. S. (2010). Resource control, revenue allocation and petroleum politics in Nigeria: the Niger Delta question.(Report). GeoJournal, 75(5), 459.

Osborne, D. (2015). Review of the Legislation establishing the Sovereign Wealth Fund in Papua New Guinea. Retrieved from http://www.nri.org.pg/images/Downloads/Publications/2015 publications/Issues paper 1 6 Review of legislation establishing the SW fund in PNG.pdf

Osborne, D., Harden, R, \& Hoy, C (2017). Economic Analysis Of Papua New Guinea. Retrieved from http://interactives.lowyinstitute.org/publications/PNGin2017/png-in-2017economics.html

Osborne, D., Harden, R., \& Hoy, C. (2017). Economic Analysis Of Papua New Guinea: A Country Assessment. Retrieved from http://interactives.lowyinstitute.org/publications/PNGin2017/png-in-2017-economics.html

Owen, A., \& Lattimore, J. (1998). Oil and gas in Papua New Guinea. Energy Policy, 26(9), 655660.

Quigley, N., Lewis, E., \& Kevin, C. (2009). "Protection of Private Property Rights and Just Compensation." http://hdl.handle.net/10063/4025.

Pacific Mining Watch. (2017). PNG's oil and gas earnings 'will' grow. Retrieved from http://mine.onepng.com/2017/08/pngs-oil-and-gas-earnings-will-grow.html?m=0

Paechter, C. Researching sensitive issues online: implications of a hybrid insider/outsider position in a retrospective ethnographic stud. Qualitative Research, 13(1), 71-86.

Papua New Guinea Extractive Industry Transparency Initiative. (2016). 2013 Report. Retrieved from https://www.pngeiti.org.pg/download/pngeiti-report-2013/

Papua New Guinea Extractive Industry Transparency Initiative. (2017a). 2014 Report Retrieved from https://eiti.org/sites/default/files/documents/papua_new_guinea_eiti_report_2014.pdf

Papua New Guinea Extractive Industry Transparency Initiative. (2017b). PNGEITI Report 2015. Retrieved from http://www.pngeiti.org.pg/wp-content/uploads/2017/12/2015-PNG-EITIREPORT.pdf

Papua New Guinea Extractive Industry Transparency Initiative. (2017c). PNGEITI Report 2016. Retrieved from https://eiti.org/sites/default/files/documents/png_eiti_2016_report.pdf

Patjole, C. (2016, December 28). Moran and Kutubu landowners sign Kroton Option PNGLoop. Retrieved from http://www.looppng.com/business/moran-and-kutubu-landowners-signkroton-option-49078

Patjole, C. (2017a, 18 August 2017). Barriers to LNG Payments must be removed Retrieved from http://www.looppng.com/business/barriers-lng-payments-must-be-removed-65048

Patjole, C. (2017b, August 16, 2017). K900 million for health sector PNGLoop. Retrieved from http://www.looppng.com/png-news/k900-million-loan-health-sector-64882

Paul Scherrer Institute and World Energy Council. (2013). World Energy Scenarios: Composing energy futures to 2050. Retrieved from https://www.worldenergy.org/wpcontent/uploads/2013/09/World-Energy-Scenarios_Composing-energy-futures-to2050 Full-report.pdf

Paust, J., \& Blaustein, A. (1974). The Arab Oil Weapon--A Threat to International Peace. The American Journal of International Law, 68(3), 410-439.

Paynter, M., Abdel, H.K, \& Alan, L. (2018). The Neo-Institutionalism Influences on Corporate Social Responsibility Reporting Development in Australia: A Three Company Study. In D. Crowther, Seifi Shahla \& Moyeen Abdul (Ed.), The Goals of Sustainable Development Responsibility and Governance. Singapore Springer 
PNG Chamber of Mines and Petroleum. (2012). Petroleum in PNG. Retrieved from http://pngchamberminpet.com.pg/petroleum-in-png/

PNG Chamber of Mines and Petroleum. (2016). Petroleum in PNG. Retrieved from http://pngchamberminpet.com.pg/petroleum-in-png/

PNG Peer Review Team. (2013). Forum Compact Peer Review Report Papua New Guinea. Retrieved from http://www.forumsec.org/resources/uploads/attachments/documents/PNG_Peer_Review_ Aug2013.pdf

PNGDoT \& BPNG. (2010). Discussion Paper Possible Creation Of A Sovereign Wealth Fund 16th April 2010. Retrieved from https://www.bankpng.gov.pg/wpcontent/uploads/2014/06/Sovereign_Wealth_Fund_Discussion_Paper_16_April_2010__Final_2.pdf

PNGexposed Blog. (2018). Take Action On The Manumanu Land Deal. Retrieved from https://pngexposed.wordpress.com/tag/manumanu/

PNGi. (2017a, 14 June, 2017). Augustine Mano: MRDC Boss And Successful Businessman.

PNGi. (2017b). Duma's Hidden Hand In K3 Billion Development. 4 July. Retrieved from http://pngicentral.org/reports/william-dumas-hidden-hand-in-k3-billion-paga-hilldevelopment

PNGi. (2017c, 21 June, 2017). The Midas Touch: How Peter O’Neill And His Associates Have Made A Killing. Retrieved from http://pngicentral.org/reports/the-midas-touch-howpeter-oneill-and-his-associates-have-made-a-killing-part-1

PNGLoop. (2018, 1 June 2018). Issues raised on public money Act 2017. Retrieved from http://www.looppng.com/png-news/issues-raised-public-money-act-2017-75661

Post Courier. (2016, 27 May 2016). Kumul Trustee Deed signed, News. Post Courier. Retrieved from http://www.postcourier.com.pg/

Post Courier. (2017a, 14 April). Know Your Political Party - Peoples National Congress, Hon. Peter O'Neill, Prime Minister of Papua New Guinea Post Courier, pp. 14-15.

Post Courier. (2017b, March 28). Know Your Political Party: National Alliance Party Post Courier pp. 14-15.

Punch, K. (2014). Introduction to social research: quantitative \& qualitative approaches (3rd ed.. ed.). Los Angeles, California: Los Angeles, California: Sage.

Radio New Zealand (Producer). (2015, 3 September 2017). Allegations of high-level money laundering in PNG. Dateline Pacific [Transcript ] Retrieved from http://www.radionz.co.nz/international/programmes/datelinepacific/audio/201760376/alle gations-of-high-level-money-laundering-in-png

Radio New Zealand. (2016, 1 June 2018). Heat on PNG PM in and outside parliament. Retrieved from https://www.radionz.co.nz/international/pacific-news/299902/heat-on-png-pm-inand-outside-parliament

Radio New Zealand. (2017a, 23/09/2017). Australian scrutiny of PNG LNG Project payments. Retrieved from http://www.radionz.co.nz/international/pacific-news/332837/australianscrutiny-of-png-lng-project-payments

Radio New Zealand. (2017b, 1 June 2018). Pressure on PNG PM to clear his name over fraud case. Retrieved from https://www.radionz.co.nz/international/pacificnews/336813/pressure-on-png-pm-to-clear-his-name-over-fraud-case

Ragin, C. C., \& Becker, Saul, B.H (Ed.) (1992). What is a case?: exploring the foundations of social inquiry. Cambridge [England] ; New York, NY, USA: Cambridge University Press.

Regan, A. (1998). Causes and course of the Bougainville Conflict. The Journal of

Pacific History 33 (3), 269-285.

Regan, A. (2014). Bougainville: Large-scale mining and the risks of conflict recurrence. Security Challenges 10(2), 71e96.

Reilly, B., Mark, B, \& Scott, F. (2015) Political Governance And Service Delivery In Papua New Guinea: A Strategic Review Of Current And Alternative Governance Systems. Discussion Paper: Vol. 143. Port Moresby, Papua New Guinea: National Research Institute.

Reymond, M. (2007). European key issues concerning natural gas: Dependence and vulnerability. Energy Policy, 35(8), 4169-4176. 
Rhodes, R. A. W. (1996). The New Governance: Governing without Government 1. Political Studies, 44(4), 652-667. doi:10.1111/j.1467-9248.1996.tb01747.x

Rhodes, R. A. W. (2000). The Governance Narrative: Key Findings and Lessons from the Erc's Whitehall Programme. Public Administration, 78(2), 345-363. doi:10.1111/14679299.00209

Robert Wood Johnson Foundation. (2017). Interviewing Retrieved from http://www.qualres.org/HomeInte-3595.html

Rodrik, D. (2008). American Economic Review: Papers \& Proceedings 98(2), 100-104.

Rogers, D. (2012). Research, practice, and the space between: Care of the self within neoliberalized institution. Cultural Studies $\leftrightarrow$ Critical Methodologies, 12(3), 242-254.

Rogner, H., Aguilera, R.F, Cristina L. Archer, C.L, Bhattarcharya, S.C, \& Dusseault, M.B. (2012). Energy Resources and Potentials. In Global Energy Assessment - Toward a Sustainable Future (pp. 425-512). New York: Cambridge University Press Retrieved from http://www.iiasa.ac.at/web/home/research/Flagship-Projects/Global-EnergyAssessment/Chapter7.en.html.

Rosen, M. E. (2009). Energy independence and climate change: The economic and national security consequences of failing to act. U. Rich. L. Rev., 44:977.

Ross, M. (2001). Does Oil Hinder Democracy? World Politics, 53(3), 325-361.

Ross, M.L. (2004). What do we know about natural resources and civil war? Journal of Peace Research 41 (3), 337-356.

Sachs, J., \& Warner, A. M. (1995). Natural resource abundance and economic growth. NBER Working Paper Series(working).

Sachs, J. D., \& Warner, A. M. (2001). Natural resources and economic development: The curse of natural resources. European Economic Review, 45, 827-838.

Sagan, S. (1998). The Origins of the Pacific War. Journal of Interdisciplinary History, 18(14), 893-922.

Samantha, S., \& Aiau, S. (2015). Spatial Analysis of Renewable Energy in Papua New Guinea through Remote Sensing and GIS. International Journal of Geosciences, 2015, 6, 853-862 https://file.scirp.org/pdf/IJG_2015081015172515.pdf

Scheepers, M., Seebregts, A, Jong, J.d, \& Maters, H. (2007). EU standards for energy security of supply. Gas 52:67.5.

Schultz, J., \& Sharpe Owen (2014). The Role of Regulation in Australia's Future Energy Mix Paper presented at the Enviro '14 Conference Adelaide, Australia https://www.nela.org.au/NELA/Documents/Finlaysons\%20-\%20Role-of-Regulation-inAustralia-Energy-Mix.pdf

Scott, R. (1994). IEA The First 20 Years (Vol. I). Paris, France: IEA/OECD.

Sean, J. (2012). Seeking optimism: Westminster in PNG. Policy: A Journal of Public Policy and Ideas, 28(4), 30-33.

Secretariat of the Pacific Community. (2012). Facilitating private Sector Participation in the Promotion of Energy Security in Papua New Guinea, Solomon Islands and Vanuatu. Retrieved from http://prdrse4all.spc.int/node/4/content/facilitating-private-sectorparticipation-promotion-energy-security-papua-new-guine-2

Siebels, J. K. A., \& Zu, D. (2012). A Review of Theory in Family Business Research: The Implications for Corporate Governance.(Report). International Journal of Management Reviews.

Skancke, M. (2003). Fiscal Policy and Petroleum Fund Management in Norway. In J. M. Davis, Ossowski, R., \& Fedelino. A. (Ed.), Fiscal Policy Formulation and Implementation in OilProducing Countries. Washington, DC.: IMF. Retrieved from http://www.imf.org/external/pubs/nft/2003/fispol/.

Smith, S. K. (2011). Deconstructing the "energy weapon": Russia's threat to Europe as case study. Energy Policy, 39(10), 6505-6513.

Söderbergh, B., Jakobsson, K, \& Kjell Aleklett, K. (2009). European energy security: The future of Norwegian natural gas production. Energy Policy, 37(12), 5037-5055. 
Sovacool, B. (2013). Energy Poverty and Development in Papua New Guinea: Learning from the Teacher's Solar Lighting Project. Forum for Development Studies, 40(2), 327-349. doi:10.1080/08039410.2012.736405

Sovacool, B. (2014). Diversity: Energy studies need social science. Nature, 511(7511), 529. doi:10.1038/511529a

Sovacool, B., \& Brown, M. (2010). Competing Dimensions of Energy Security: An International Perspective. Annual Review of Environment and Resources, 35, 77.

Sovacool, B., \& Mukherjee, I. (2011). Conceptualizing and measuring energy security: A synthesized approach. Energy, 36(8), 5343-5355. doi:10.1016/j.energy.2011.06.043

Sovacool, B., \& Andrews, N. (2015). Does transparency matter? Evaluating the governance impacts of the Extractive Industries Transparency Initiative (EITI) in Azerbaijan and Liberia. Resources Policy, 45, 183.

Sovacool, B., \& Dworkin, M. (2015). Energy justice: Conceptual insights and practical applications. Applied Energy, 142, 435.

Sovacool, B., Walter, G., Van De Graaf, T., \& Andrews, N. (2016). Energy governance, transnational rules, and the resource curse: exploring the effectiveness of the Extractive Industries Transparency Initiative ( EITI). World Development. doi:10.1016/j.worlddev.2016.01.021

Sovacool, B. K. (2011a). Introduction from: The Routledge Handbook of Energy Security Routledge Retrieved from https://www.routledgehandbooks.com/doi/10.4324/9780203834602

Sovacool, B. K. ( 2011b). Evaluating energy security in the Asia pacific: Towards a more comprehensive approach. Energy Policy, 39(11), 7472-7479.

Stake, R. (1995). The Art of case study Research. Thousand Oaks, London, New Delhi: Sage.

Stake, R. (1998). "Case Studies". In Norman Denzin \& Y. Lincoln. (Eds.), Strategies of Qualitative Inquiry. Thousand Oaks, London, New Delhi: Sage.

Standish, B. (2007). 'The dynamic of Papua New Guinea's democracy: An essay', Pacific Economic Bulletin, 22(1):135-157.

Stevens, P. (2003). Resource Impact: Curse or Blessing? - A Literature Survey. The Journal of Energy Literature, IX(1).

Stevens, P. (2010). The 'Shale Gas Revolution': Hype and Reality. Retrieved from London: https://www.chathamhouse.org/publications/papers/view/178865

Stevens, P., \& Dietsche, E. (2008). Resource curse: An analysis of causes, experiences and possible ways forward. Energy Policy, 36(1), 56-65. doi:10.1016/j.enpol.2007.10.003

Stijns, J. P. C. (2006). Natural resource abundance and uman capital accumulation. World Development, 34, 1060-1083.

Stirling, A. (1994). Diversity and ignorance in electricity supply investment: addressing the solution rather than the problem. Energy Policy 22(3), 195-216.

Sturesson, A., \& Zobel Thomas (2015). The Extractive Industries Transparency Initiative (EITI) in Uganda: Who will take the lead when the government falters? The Extractive Industries and Society, 2, 33-45.

Tararia, A., \& Lisa, O. (2010). Incorporated Land Groups and the Registration of Customary Land: Recent Developments in PNG. http://milda.aidwatch.org.au/sites/default/files/Incorporated\%20land\%20groups\%20and\% 20the\%20registration\%20of\%20customary\%20lands.pdf

Tax Review Committee. (2015a). Papua New Guinea Taxation Review Report to the Treasurer Part lof 2: Summary of Analysis. Retrieved from http://www.treasury.gov.pg/html/media_releases/files/2016/Tax\%20Review\%20\%20Final \%20Report\%20vol\%201.pdf

Tax Review Committee. (2015b). Papua New Guinea Taxation Review: Report to the Treasurer Part 2 of 2: Detailed Analysis. Retrieved from http://www.treasury.gov.pg/html/media_releases/files/2016/Tax\%20Review\%20Final\%20 report\%20Vol\%202.pdf

Taylor, J. (2011). The intimate insider: Negotiating the ethics of friendship when doing insider research. Qualitative Research, 11(1), 3-22. 
Teme, K. (2017, March 17). Govt Gives K300m for Plaza. Post Courier Retrieved from http://postcourier.com.pg/govt-gives-k300m-for-plaza/

The Electricity Journal. (2013). On 10th Anniversary of 03 Blackout, What Have We Learned? Electricity Journal, 26(8), 1-6.

The Guardian. (2017, 1 June 2018). Arrest warrant for PNG prime minister Peter O'Neill thrown out of court. Retrieved from https://www.theguardian.com/world/2017/dec/18/arrestwarrant-for-png-prime-minister-peter-oneill-thrown-out-of-court

The National. (2010). PNG Supreme Court Revokes Political Reforms, Destablises System. Papua New Guinea: The National News Paper.

The National (March 20, 2018). Policy on natural gas is good news. https://www.thenational.com.pg/policy-natural-gas-good-news/

The National (29 April, 2019). PPL, NiuPower seal gas-fired power deal. https://www.thenational.com.pg/ppl-niupower-seal-gas-fired-power-deal/

The National (27 October, 2016a). https://www.thenational.com.pg/png-lng-landownerspraise-former-minister/

The National. (2016b). KPHL Fires up PNG Gas, Oil. The National.

The National. (2016c, 21 July 2016). Most accord commitments achieved. The National. Retrieved from http://www.thenational.com.pg/most-accord-commitments-achieved/

The National. (2016d). PNG LNG Project Beneficiary Group Comprising Impacted Provincial Governments And PDL, Pipeline, and Plant Site Landowers [Press release]

The National. (2017, 26 May). Kumul working to fix PPL management team: Abe. The National Retrieved from https://www.thenational.com.pg/kumul-working-fix-ppl-managementteam-abel

Thurber, M. C., David R. Hults, and Heller Patrick R.P. (2011). Exporting the "Norwegian Model": The effect of administrative design on oil sector performance. Energy Policy.

Tlozek, E. (2017 2/09/2017). PNG election: Corruption and economy are Peter O'Neill's biggest worries as polls open. Retrieved from http://www.abc.net.au/news/2017-06-25/pngelection-peter-oneill-corruption-economy/8648196

Togolo, M. 2006. "The 'Resource Curse' and Governance: A Papua New Guinean Perspective." In Globalisation, Governance and the Pacific Islands, edited by Stewart Firth, 275-285. Canberra: The Australian National University E Press.

https://press.anu.edu.au/publications/series/state-society-and-governancemelanesia/globalisation-and-governance-pacificc

Tornell, A., \& Lane, P.R. (1999). The Voracity Effect. The American Economic Review, 89(1), 22-46.

Torres, C. S. R. (2015). Norway's Oil And Gas Sector: How Did The Country Avoid The Resource Curse? Retrieved from http://www.en.ipea.gov.br/agencia/images/stories/PDFs/rtm/150305 rtm v1_n1_port ca p4.pdf

Torvik, R. (2000). Natural resources, rent seeking and welfare. Journal of Development Economics, 67, 455-470.

Trading Economics. (2018). Papua New Guinea GDP Annual Growth Rate 1995-2018. Retrieved from https://tradingeconomics.com/papua-new-guinea/gdp-growth-annual

Transparency International PNG. (2017). Appointment of Duma is a Mockery of Justice [Press release]. Retrieved from http://www.transparencypng.org.pg/wp-

content/uploads/2017/08/TIPNG-PR_040817_Appointment-of-Duma-is-a-Mockery-ofJustice-_2_.pdf

Tsani, S. (2015). On the relationship between resource funds, governance and institutions: Evidence from quantile regression analysis. Resources Policy, 44, 94.

Turner, M. M. (1997). Governance, administration and development: making the state work. West Hartford, Conn.: West Hartford, Conn. : Kumarian Press.

United Nations Development Program. (1997). Energy After Rio:Prospects and Challenges. Retrieved from http://www.hubrural.org/IMG/pdf/pnud_energy_after_rio.pdf 
United Nations Development Program. (2015). 2014 Human Development Report. Papua New Guinea. Retrieved from http://hdr.undp.org/sites/default/files/2014_png_national_human_development_report.pdf

United States Department For International Development. (2001). Making Government Work for the Poor. Retrieved from http://www.gsdrc.org/docs/open/tsp.pdf

United States Department For International Development. (2006). Analysis of Incentives and Capacity for Poverty Reduction in Kyrgyzstan. Retrieved from http://www.gsdrc.org/docs/open/DOC50.pdf

Ushie, V. (2013). The Management and Use of Natural Resources and their Potential for Economic and Social Development in the Mediterranean(13). Retrieved from https://www.ciaonet.org/attachments/24087/uploads

Velculescu, D. (2008, July 9, 2008). IMF Survey: Norway's Oil Fund Shows the Way for Wealth Funds. Retrieved from https://www.imf.org/en/News/Articles/2015/09/28/04/53/sopol070908a

Victor, D. G., \& Yueh, L. (2010). The New Energy Order. Foreign Affairs, 1, 61-73.

Voigt-Graf, C., Sanida, Osborne. (2015). PNG's 2015 Sovereign Wealth Fund Bill: Key Weaknesses and Proposals for Improvement 8(3). Retrieved from https://pngnri.org/wpcontent/uploads/2016/07/SL8-3-201512-Voigt-Sovereign-Wealth-Fund-Bill.pdf

Watson, A. H. A., \& Wiltshire, C. (2016). Reporting Corruption from within Papua New Guinea's Public Financial Management System.(6). Retrieved from http://ssgm.bellschool.anu.edu.au/sites/default/files/publications/attachments/201609/dp 20165 watson and wiltshire.pdf

Watts, M. (1999). Curse of the Black Gold: 50 years of Oil in the Niger Delta: Powerhouse Books.

Watts, M. (2004a). Resource curse? Governmentality, oil and power in the Niger Delta, Nigeria. Geopolitics 9 (1), 50-80.

Watts, M. (2004b). The Sinister Political Life of Community. Economies of Violence and Governable Spaces in the Niger Delta, Nigeria. Niger Delta Economies of Violence Working Paper No. 3. Institute of International Studies, University of California, Berkeley.

Watts, M. (2004c). Violent environments: petroleum conflict and the political ecology of rule in the Niger Delta, Nigeria. In: Peet, R., Watts, M. (Eds.), Liberation Ecologies, second ed. Routledge, New York, pp. 273-298.

Wayne, M. J., \& Knutsen, T.L. (2007). Ways of knowing: competing methodologies in social and political research. Basingstoke, Hampshire; New York: Palgrave Macmillan.

Webster, T., \& Linda, D. (2010). Papua New Guinea's Development Performance 1975-2008. Retrieved from http://www.nri.org.pg/publications/Recent\%20Publications/ Dvp_Report_with_cover_300810.pdf

Weiner, J., \& Glaskin, K. (Eds.). (2007). Customary Land Tenure and Registration in Australia and Papua New Guinea: Anthropological Perspectives. Asia-Pacific Environment Monograph 3. ANU E Press, Canberra, pp. 1-14.

Wickberg, S. (2013). Papua New Guinea: overview of corruption and anti-corruption Retrieved from www.u4.no/.../papua-new-guinea-overview-of-corruption-and-anticorruption/.../310.

Winzer, C. (2012). Conceptualizing energy security. Energy Policy, 46, 36-48.

Wolcott, H. F. (1994). Transforming Qualitative Data Description, Analysis, and Interpretation USA University of Oregon.

Wolfers, E. P. (2012, March 28). Political impasse in Papua New Guinea. Aljazeera. Retrieved June 4, 2019, from https://www.aljazeera.com/indepth/opinion/2012/03/201232582148346270.html

Wood, T. (2018). The clientelism trap in Solomon Islands and Papua New Guinea, and its impact on aid policy. Asia Pacific Policy Studies.

https://onlinelibrary.wiley.com/doi/pdf/10.1002/app5.2399 
World Bank. (1992). Governance and Development. Retrieved from Washington, DC: World Bank.: http://documents.worldbank.org/curated/en/604951468739447676/Governanceand-development

World Bank. (2001). The World Bank Group's Energy Program Poverty Reduction, Sustainability And Selectivity. Retrieved from

http://siteresources.worldbank.org/INTENERGY/Publications/20269216/energybrochure. pdf

World Bank. (2008). The Political Economy of Policy Reform: Issues and Implications for Policy Dialogue and Development Operations Social (44288-GLB). Retrieved from http://siteresources.worldbank.org/EXTSOCIALDEV/Resources/The Political Economy _of_Policy_Reform_Issues_and_Implications_for_Policy_Dialogue_and_Development_O perations.pdf

World Bank. (2010). Lights out? The Outlook for Energy in Eastern Europe and Central Asia. Retrieved from https://openknowledge.worldbank.org/handle/10986/2433 License: CC BY 3.0 IGO."

World Bank. (2017). Papua New Guinea Economic Update: Reinforcing Resilience. Retrieved from http://www.worldbank.org/en/news/press-release/2017/12/05/png-taking-steps-toreinforce-economic-resilience

World Bank. (2018). PNG Energy Sector Development Project Retrieved from http://projects.worldbank.org/P101578/png-energy-sector-development-project?lang=en

Yala, C., Sanida, O, \& Mako A. A. (2014). State's acquisition of equity in Oil Search Ltd has significant implications for the PNG economy with significant welfare implications. Retrieved from http://www.devpolicy.org/the-oil-search-loan-implications-for-png20140321-2/

Yergin, D. (1991). The prize: the epic quest for oil, money and power. New York; London: Simon $\&$ Schuster. Pocket Books.

Yergin, D. (2006). Ensuring energy security. Foreign Affairs, 85(2), 69-82.

Yergin, D. (2006). The New Energy Security Paradigm (WEF Ed.). Geneva, Switzerland: World Economic Forum.

Yergin, D. ( 1988). Energy Security in the 1990s. Foreign Affairs, 67(1), 110-132.

Yin, R. K. (2009). Case study research: design and methods (4th ed.. ed.). Los Angeles, Calif.: Sage Publications.

Yin, R. K. (Ed.) (2014). Case study research: design and methods (5 ed.). Los Angeles: SAGE. Yu, W., and Michael G. Pollitt. (2009). Does Liberalisation Cause More Electricity Blackouts?: Evidence from a Global Study of Newspaper Reports.

Zweig, D., \& Jianhai, B. (2005). China's Global Hunt for Energy. Foreign Affairs, 84(5), 25-38.

\section{Acts/Legislation}

Constitutional Amendment Number 44 (Papua New Guinea's Ownership of Hydrocarbons and Minerals and the Consolidation and Commercialisation of Papua New Guinea's Business) Law 2016 (2016a).

Government of Papua New Guinea. (2015d). Organic Law on Sovereign Wealth Fund (Amended)8(3). Retrieved from https://pngnri.org/wp-content/uploads/2016/07/SL8-3201512-Voigt-Sovereign-Wealth-Fund-Bill.pdf

Income Tax Act 1959, (1959).

Independent Public Business Corporation (Amended) (2014).

Independent Public Business Corporation Act (2002).

Kumul Consolidated Act. (2015b).

Kumul Petroleum Holdings Limited Authorisation Act, (2015c).

Oil and Gas Act 1998 (Amended), (1998b).

Oil and Gas Act, (1998a).

Organic Law on Sovereign Wealth Fund (Amended), (2015e).

Organic Law on Sovereign Wealth Fund, (2012).

Papua New Guinea's Constitution of 1975 with Amendments through 2014, (2014).

Petromin Act. (2007). 
Public Funds Management Regularisation Act 2018, (2018).

Unconventional Hydrocarbon Act 2015, (2015g). 


\section{APPENDICES}

\section{Appendix 1: List of Interviewees}

\begin{tabular}{|c|c|}
\hline Government agencies & Informants \\
\hline $\begin{array}{l}\text { Ministry \& Dept. Petroleum } \\
\text { and Energy }\end{array}$ & $\begin{array}{ll}- & \text { Minister or First Secretary } \\
\text { - } & \text { Secretary or head policy and governance }\end{array}$ \\
\hline $\begin{array}{l}\text { Ministry \& Dept. state } \\
\text { enterprise and public } \\
\text { investment }\end{array}$ & $\begin{array}{ll}\text { - } & \text { Minister or First Secretary } \\
\text { - } & \text { Secretary or head of policy and governance }\end{array}$ \\
\hline Ministry \& Dept. Finance & $\begin{array}{ll}- & \text { Minister or First Secretary } \\
\text { - } & \text { Secretary or head of projects }\end{array}$ \\
\hline Ministry \& Dept. Treasury & $\begin{array}{ll}- & \text { Minister or First Secretary } \\
- & \text { Secretary or head of economic policy and Sovereign } \\
& \text { Wealth Fund }\end{array}$ \\
\hline $\begin{array}{l}\text { Ministry \& Dept. National } \\
\text { Planning \& Monitoring }\end{array}$ & $\begin{array}{ll}- & \text { Minister or First Secretary } \\
- & \text { Secretary or head of economic policy }\end{array}$ \\
\hline $\begin{array}{l}\text { Office of the Prime Minister } \\
\text { \& Dept. Prime Minister and } \\
\text { NEC }\end{array}$ & $\begin{array}{l}\text { - Chief of Staff/Deputy Chief of Staff. If possible, the } \\
\text { Prime Minister or deputy Prime Minister } \\
\text { - Chief Secretary or principal economic advisor }\end{array}$ \\
\hline $\begin{array}{l}\text { Ministry \& Dept. Provincial } \\
\text { Affairs \& Local Level Gov't }\end{array}$ & $\begin{array}{ll}\text { - } & \text { Minister or First Secretary } \\
\text { - } & \text { Secretary or head of policy and governance }\end{array}$ \\
\hline State-owned Enterprises & \\
\hline $\begin{array}{l}\text { Kumul Petroleum Holdings } \\
\text { Ltd }\end{array}$ & Managing Director or head of governance \\
\hline PNG Power Ltd & Head of corporate governance or energy governance \\
\hline Civil Society Organisations & \\
\hline $\begin{array}{l}\text { PNG extractive Transparency } \\
\text { Initiative Secretariat }\end{array}$ & Head of PNGEITI or technical advisor \\
\hline Think Thanks & \\
\hline National Research Institute & Director or head of economic policy program \\
\hline Institute of National Affairs & Director or senior researcher \\
\hline
\end{tabular}




\begin{tabular}{|c|c|}
\hline $\begin{array}{l}\text { Landowners' Incorporated } \\
\text { Association }\end{array}$ & Presidents \\
\hline \multicolumn{2}{|c|}{ International Oil \& Gas Companies } \\
\hline Exxon- Mobil (PNG) & Head of government business relations \\
\hline InterOil & Head of government business relations \\
\hline
\end{tabular}




\section{Appendix 2: Semi-structured Interview Guiding Questions}

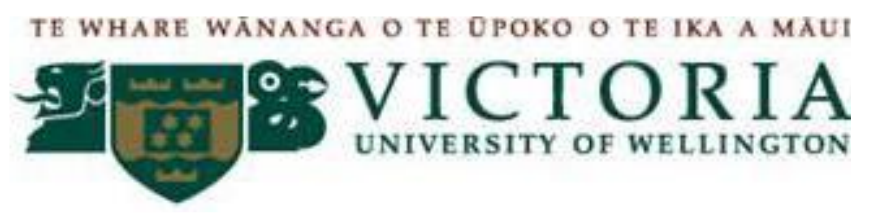

School of Government

\section{Government Agencies/Ministries}

- Does the term energy governance have some meaning for you? Can you elaborate on what you think it is?

- What is your role in energy governance and energy security? How would you define energy security and energy governance? Do you think that there is a relationship between energy governance and energy security? If so, how would you describe it?

- What are some of the problems/issues and challenges you think the government or your agency faces in governing liquid fuels? Do you think energy governance in terms of liquid fuel governance contributes to energy security? And if so how? How has the government managed rents from the liquid fuel? Do you think the approach has been successful? What improvements would you suggest to the approach?

- How has the government responded to the energy security crises? Do you think this approach has been a success and why do you think that, or not? Do you think there is something that could be done differently?

- How has the government managed resource owners' issues? Do you think the strategy has proved successful from the resource owner's (traditional landowners') perspective? And what about from the perspective of the PNG people? Is the current practice effective and efficient?

\section{State-owned Enterprises}

- How do you understand the relationship between the company and the government? Does the notion of energy security have meaning for you and what is that meaning? Do you think that there is a relationship between energy governance and energy security and can you describe that relationship?

- What is the company's role in energy governance? Does the company contribute to energy security and in what ways? How does your role and that of others in the company contribute to governance of energy and energy security?

- What are some of the issues and challenges in governing liquid fuels? Do you think energy governance in terms of liquid fuel governance contribute to energy security? And if so, how would you describe it?

- What are some of the company's approaches in governing liquid fuel? How has the company manage rents from the liquid fuels? How has the company 
responded to the energy security crises? How has the company managed resource owners' issues? Do you think the approach or strategy has been successful? Is the current practice effective and efficient? In what ways do you think this could be improved?

\section{Civil Society Organisations}

- What do you understand the role of your CSO to be in respect of energy governance and energy security? How do you understand the notions of energy security and energy governance? Do you think that there is a relationship between energy governance and energy security? Can you describe what you understand that relationship to be?

- Do you think energy governance in terms of liquid fuel governance contributes to energy security? If so how?

- How transparent is the government's and SoEs' approach in governing liquid fuel and liquid fuel rents? From the perspective of your CSO, what are some of the problems/issues and challenges in the governance of liquid fuels?

- Do you think the government's and SoEs' approach in governing liquid fuels has been a successful one from your CSO's perspective? Why/why not? How effective is your role in advocating good governance pertaining to liquid fuels? Have they been successful? How might they be improved?

\section{Resource Owners (Traditional Landowners of the land)}

- What do you understand your role in relation to government's and SoE's governance of oil rents? What do you think about the way the government is managing your benefits? What are some of the problems/issues and challenges you face in the current arrangement between resource owners and government and SoEs?

- Do you think the current practice is effective and efficient? How might the government and SoEs improve in the way they manage your benefits and deal with your issues?

\section{Experts and Think Thanks}

- How do you position your role in energy governance and energy security? Are the concepts of energy security and energy governance part of what you think about, and how do you think about these terms? Do you think that there is a relationship between energy governance and energy security? And if so what is it?

- Do you think that energy governance in terms of liquid fuel governance contributes to energy security? And if so, in what ways? What are some of the problems/issues and challenges in the governance of liquid fuels?

- What do you think about the government's and SoEs' approach in governing liquid fuel? Is it successful or efficient and effective in providing benefits to the PNG people? In what ways? How transparent are the government's and SoEs' approaches in governing liquid fuel and liquid fuel rents? 
- How effective is your role in advocating good governance pertaining to liquid fuels? Have the current practices/approaches/strategies been successful? In what ways do you think they should be improved? 


\section{Appendix 3: Letter on Request for an Interview}

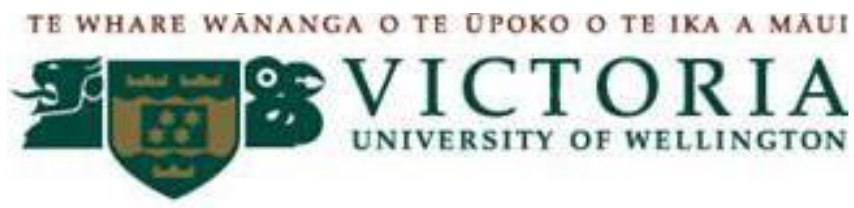

School of Government

\section{[Insert date]}

\section{[Insert name of CEO/Authority, Designation, Ministry/Agent]}

\section{[Dear Sir/Madam]}

I am a PhD student in Public Policy at the Victoria University of Wellington, New Zealand. My research project is about how political governance of liquid fuels contributes to energy security in Papua New Guinea.

You have been identified and selected as a key person whose input will be an integral part of this research. I would like to ask for an interview with you at a date and time that is convenient to you. Information about this research is provided in the attached Information Sheet. The Consent Form to be completed by you is also attached.

Please contact me on the phone [...] or email address [...]

Thank you for your cooperation and look forward to hearing from you soon.

Yours sincerely,

Signed:

Francis Hualupmomi

PhD Student

School of Government

Victoria University of Wellington

PO Box 600

Wellington, NZ

Email: francis.hualupmomi@vuw.ac.nz

Phone: + 644639406

Local phone: [....] 


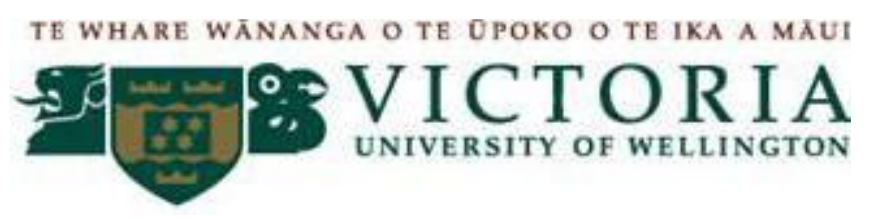

School of Government

\section{[Insert date]}

[Insert name of CEO/Authority, Designation, Ministry/Agent]

\section{[Dear Sir/Madam]}

\section{An Analysis of How Political Governance of Liquid Fuels Contributes to Energy Security in Papua New Guinea}

I write to you to seek your permission to undertake this research project with your ministry/agency. The research is an exploration into understanding how political governance of liquid fuels contributes to energy security in Papua New Guinea.

This research is part of my fulfilment of the Doctor of Philosophy in Public Policy under the direct supervision of School of Government, Victoria University of Wellington, New Zealand. I am the principal researcher of this project. The Ethics Approval has been obtained from the Victoria University of Wellington and research protocols will be observed to maintain confidentiality during the course of the research in PNG.

As part of the data collection, I would like to interview key stakeholders and conduct desk top and documentary analysis on key documents of your ministry/agency about how liquid fuels have been governed in order to understand how it generates/enhances insecurity of energy in the country. I am particularly interested in the stakeholders' views, experiences and factors affecting governance of energy security.

Your Ministry/Agency has been selected for this study because of its role as the [central policy coordinator or sector lead agency or implementing agency] in the [name sector] of government. In this respect, I would like to seek your approval for an interview with the following staff of your Ministry/agency.

\begin{tabular}{|l|l|}
\hline Name & Designation \\
\hline [Insert name] & [Insert Designation] \\
\hline [Insert name] & [Insert designation] \\
\hline
\end{tabular}


I would also like to guarantee you that participation in this research will be voluntary and based on the participants' willingness. This will be further elaborated in the Information sheet and Consent form that will be provided to each participant prior to the interview. These documents will explain the purpose and nature of the project and how the information provided will be handled in terms of confidentiality and anonymity.

With your approval, I will contact them individually to confirm their willingness to participate and their availability for an interview.

The findings of the research project can be made available to your office upon request. It is hoped that findings from this study will contribute to an improved understanding of how governance of energy security in terms of liquid fuels could be better improved in the future.

Your favourable approval will be greatly appreciated.

Findings of this research will be made available to your office upon request. It is hoped that this research will help contribute towards improving energy governance in PNG.

I can be contacted using the following details.

Yours sincerely,

Researcher Detail:

Francis Hualupmomi

PhD Student

School of Government

Victoria University of Wellington

PO Box 600

Wellington, NZ

Email: francis.hualupmomi@vuw.ac.nz

Phone: + 644639406

5047

Under Supervision of:

Dr Elizabeth Eppel

Secondary Supervisor

School of Government

PO Box 600

Wellington, NZ

Email: Elizabeth. elizabeth.eppel@vuw.ac.nz

Phone: $+\underline{6444637525}$
Under Supervision of:

Associate Professor

Graham Hassall

Primary Supervisor

School of Government

Victoria University of

Wellington

PO Box 600

Wellington, NZ

Email: Graham.Hassall@vuw.ac.nz

Phone: +64-4-463 


\section{Appendix 5a: Participation Information}

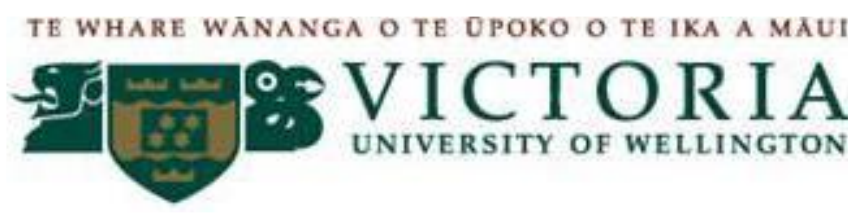

School of Government

[Insert date]

Project Title: Analysis of How Political Governance of Liquid Fuels Contributes to Energy Security

\section{Researcher: Francis Hualupmomi, PhD Student, School of Government, Victoria University of Wellington, New Zealand}

It's a great pleasure to invite you to participate in my research.

I am a PhD Student in Public Policy, at the Victoria University of Wellington, New Zealand. My thesis explores how governance of energy at institutional level contributes to energy security by focusing on political governance of liquid fuels in Papua New Guinea. The study aims to analyse how liquid fuel is governed at political and policy institutions in order to understand how it contributes to insecurity of energy in the country. In so doing, it helps contribute to the existing body of knowledge in public policy and energy security as well as improving governance of energy security in PNG. My research would be of interest for the government of PNG as well.

I am a Papua New Guinean currently under a Government of PNG and Victoria University of Wellington Scholarship. Prior to that, I was with the PNG public service for almost 9 years. The university has approved my study including ethics approval to conduct this research. My research is under the direct supervision of two academic supervisors and in accordance with the established policies and procedures of the university.

The protocols for interview are guided by the Consent Form. This has a number of criteria:

- Interviewee have the preferences of choice

- Participation is voluntary based on interviewees' willingness

- Participants' may reserve the right to withdraw within a period of 1 month from the date of interview

- Name of interviewees will not be disclosed in the analysis, thesis or articles

- Consent forms, hand notes, tape recordings or any other material collected in connection with the interviewee will be kept confidential

- Information supplied to my supervisors or other supervisors or other researchers will not be in any way contain the names of the interviewee

- It may not always be possible for those interviewees that are well known to conceal their identity

As a requirement of the University, the thesis will be submitted to the School of Government and deposited in the University Library. As part of my academic and professional career, the information contained in the thesis will also be used for one or more articles that will be submitted for publication in international journals. This may include presentation in academic or professional conferences. Do note also that the information 
gathered during the course of interview will be destroyed 3 years after the full completion of my doctoral degree.

For any matters or information pertaining to my research, please do not hesitate to contact me or my primary supervisor, Associate Professor Graham Hassall, School of Government at Victoria University of Wellington.

I greatly appreciate your information during the course of interview.

Sincerely

Researcher Detail:

Under Supervision of:

Francis Hualupmomi

Associate Professor

PhD Student

Graham Hassall

School of Government

Primary Supervisor

Victoria University of Wellington

School of Government

Victoria University of

PO Box 600

Wellington

Wellington, NZ

PO Box 600

Email: francis.hualupmomi@vuw.ac.nz

Phone: + 644639406

Wellington, NZ

5047

Under Supervision of:

Dr Elizabeth Eppel

Secondary Supervisor

School of Government

PO Box 600

Wellington, NZ

Email: Elizabeth. elizabeth.eppel@vuw.ac.nz

Phone: $+\underline{6444637525}$ 


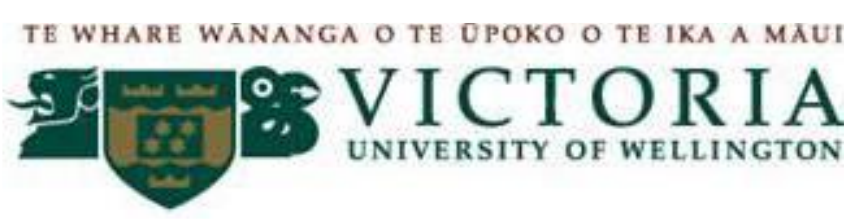

School of Government

Project Title: An Analysis of How Political Governance of Liquid Fuels Contributes to Energy Security

Date of interview:

Place of the interview:

Duration of the interview:

Interviewee:

Identifier for the interviewee:

Gender, age, nationality of interviewee:

Profession/designation of the interviewee:

Working in the profession since:.

Consent provided:

Peculiarities of interviewee: 
Gender, age, nationality of the interviewee:

Profession/designation of the interviewee:

Working in the profession since:

Consent provided:

Peculiarities of the interview: 
Appendix 6: Policies, Legislation and Reports selected for Content and Thematic Analysis

\begin{tabular}{|c|c|c|}
\hline Document & Content or Indicators & Source \\
\hline Legislation & & \\
\hline PNG Constitution Amended 2014 & $\begin{array}{l}\text { Nine Goals and Directive } \\
\text { Principles }\end{array}$ & $\begin{array}{l}\text { Pacific Islands Legal } \\
\text { Information Institute }\end{array}$ \\
\hline Constitutional Amendment 44 & $\begin{array}{l}\text { Governance of hydrocarbon } \\
\text { related to ownership }\end{array}$ & $\begin{array}{lrr}\text { Department } \quad \text { of } & \text { State } \\
\text { Enterprise and } & \text { Public } \\
\text { Investment } & & \end{array}$ \\
\hline $\begin{array}{l}\text { Organic Law on Sovereign Wealth } \\
\text { Fund } 2012 \text { and } 2015\end{array}$ & $\begin{array}{l}\text { Governance of petroleum funds } \\
\text { related to ownership, Board and } \\
\text { finance }\end{array}$ & $\begin{array}{l}\text { NRI Website and } \\
\text { Department of Treasury } \\
\text { Website }\end{array}$ \\
\hline Oil and Gas Act 1998 & $\begin{array}{l}\text { Governance of oil and gas related } \\
\text { to ownership and board }\end{array}$ & $\begin{array}{lrr}\text { Department } \text { of } & \text { State } \\
\text { Enterprise and } & \text { Public } \\
\text { Investment } & & \end{array}$ \\
\hline IPBC Act 2002 and amended 2014 & $\begin{array}{l}\text { Governance of SOEs related } \\
\text { ownership and Board }\end{array}$ & $\begin{array}{lrr}\text { Department } \quad \text { of } & \text { State } \\
\text { Enterprise and } & \text { Public } \\
\text { Investment } & & \end{array}$ \\
\hline Petromin Act 2007 & $\begin{array}{l}\text { Governance of petroleum related } \\
\text { to ownership and Board }\end{array}$ & $\begin{array}{lrr}\text { Department } \quad \text { of } & \text { State } \\
\text { Enterprise and } & \text { Public } \\
\text { Investment } & & \end{array}$ \\
\hline $\begin{array}{l}\text { Kumul Consolidated Holdings Act } \\
2015\end{array}$ & $\begin{array}{l}\text { Governance of petroleum related } \\
\text { to ownership, Board and finance }\end{array}$ & $\begin{array}{l}\text { Kumul } \\
\text { Holdings }\end{array}$ \\
\hline $\begin{array}{l}\text { Kumul Petroleum Holdings } \\
\text { Limited Authorisation Act } 2015\end{array}$ & $\begin{array}{l}\text { Governance of petroleum related } \\
\text { to ownership, Board and finance }\end{array}$ & $\begin{array}{lrr}\text { Department } \quad \text { of } & \text { State } \\
\text { Enterprise and } & \text { Public } \\
\text { Investment } & & \end{array}$ \\
\hline
\end{tabular}




\begin{tabular}{|c|c|c|}
\hline $\begin{array}{l}\text { Unconventional Hydrocarbon Act } \\
2015\end{array}$ & $\begin{array}{l}\text { Governance of petroleum related } \\
\text { to ownership, Board and finance }\end{array}$ & $\begin{array}{lrr}\text { Department of } & \text { State } \\
\text { Enterprise and Public } \\
\text { Investment }\end{array}$ \\
\hline \multicolumn{3}{|l|}{ Policies } \\
\hline $\begin{array}{l}\text { PNG National Energy Policy 2016- } \\
2020\end{array}$ & $\begin{array}{l}\text { Governance of energy } \\
\text { (petroleum, oil and gas) }\end{array}$ & $\begin{array}{l}\text { Department of State } \\
\text { Enterprise and Public } \\
\text { Investment }\end{array}$ \\
\hline PNG National Security Policy 2013 & $\begin{array}{l}\text { National security threats priorities } \\
\text { and how it contributes to energy } \\
\text { security and development }\end{array}$ & $\begin{array}{l}\text { Office of Security } \\
\text { Coordination, Department of } \\
\text { Prime Minister \& NEC }\end{array}$ \\
\hline \multicolumn{3}{|l|}{ Reports } \\
\hline $\begin{array}{l}\text { PNG Human Development Report } \\
2014\end{array}$ & $\begin{array}{l}\text { Governance of petroleum and } \\
\text { contribution to development }\end{array}$ & $\begin{array}{l}\text { Department of National } \\
\text { Planning and Monitoring } \\
\text { Website }\end{array}$ \\
\hline 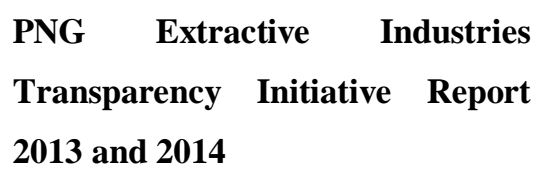 & $\begin{array}{l}\text { Outcomes of the financial report } \\
\text { of extractive industries }\end{array}$ & PNGEITI Website \\
\hline $\begin{array}{l}\text { National Research Institute } \\
\text { Reports on Sovereign Wealth Fund } \\
2015 \text { and UBS Loan } 2017\end{array}$ & $\begin{array}{l}\text { Perspectives on Sovereign Wealth } \\
\text { Fund and Acquisition of UBS } \\
\text { Loan }\end{array}$ & NRI Website \\
\hline $\begin{array}{l}\text { Institute of National Affairs } 2016 \\
\text { Resource Sector Report }\end{array}$ & $\begin{array}{l}\text { Perspectives on resource sector } \\
\text { and development }\end{array}$ & INA Website \\
\hline
\end{tabular}




\section{Appendix 7 Codes for Participants}

\section{Institution}

State Institution

Regulatory Institution

Revenue-Generating Institution

P2 Senior Auditor

P20 Senior officer

P3 Senior officer

P13 Senior officer

P7

\section{Producing Institution}

Research Institution

CSO (including Landowner Assoc.) P4 Governance coordinator

P6 Chief of Landowners' Association

P10 Governance coordinator

P15 Landowner

Academia

P14 Senior academic

P17 Senor academic 
Appendix 8. NVivo Tree Map of main themes and subthemes

8A. Main themes and subthemes

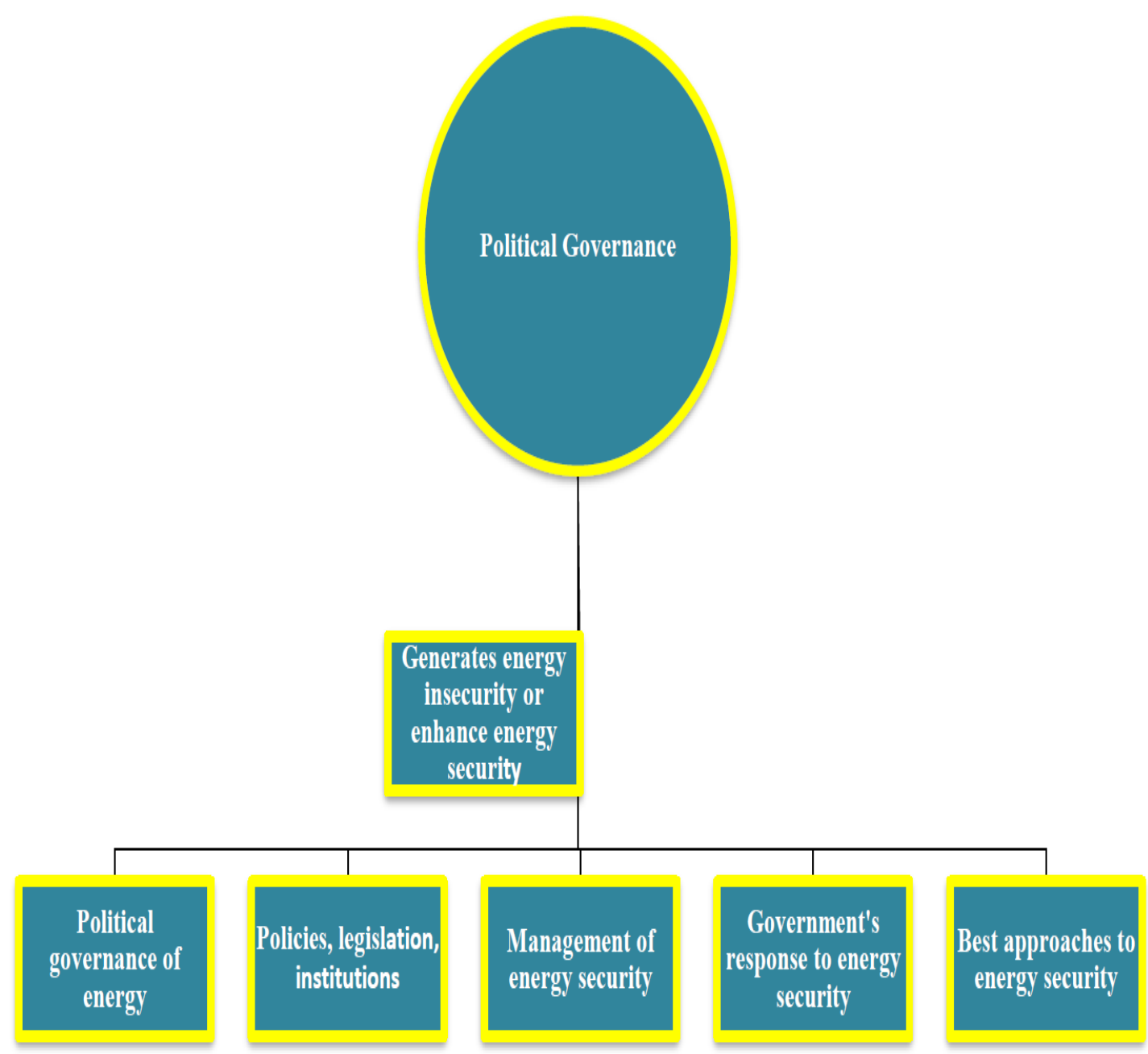


8B. Theme 1: Political Governance of Energy Security

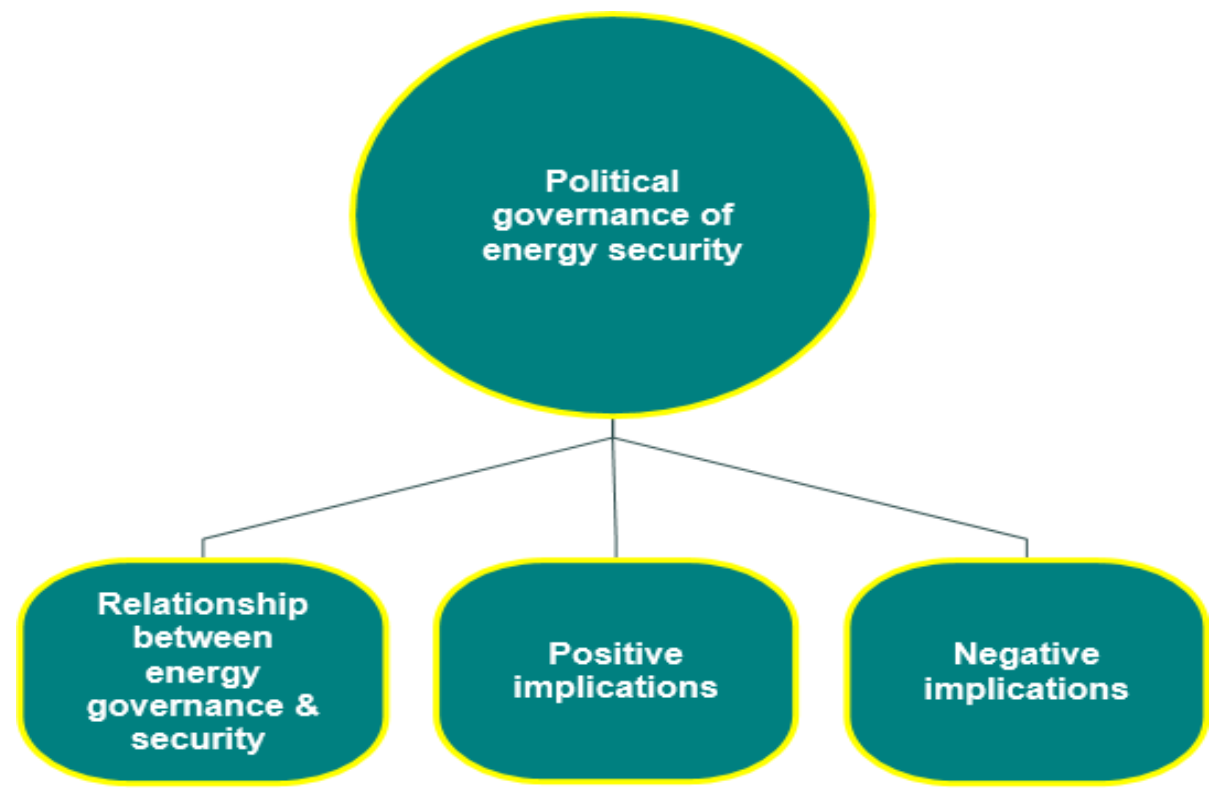

8C. Theme 2: Policies, Legislation \& Institutions

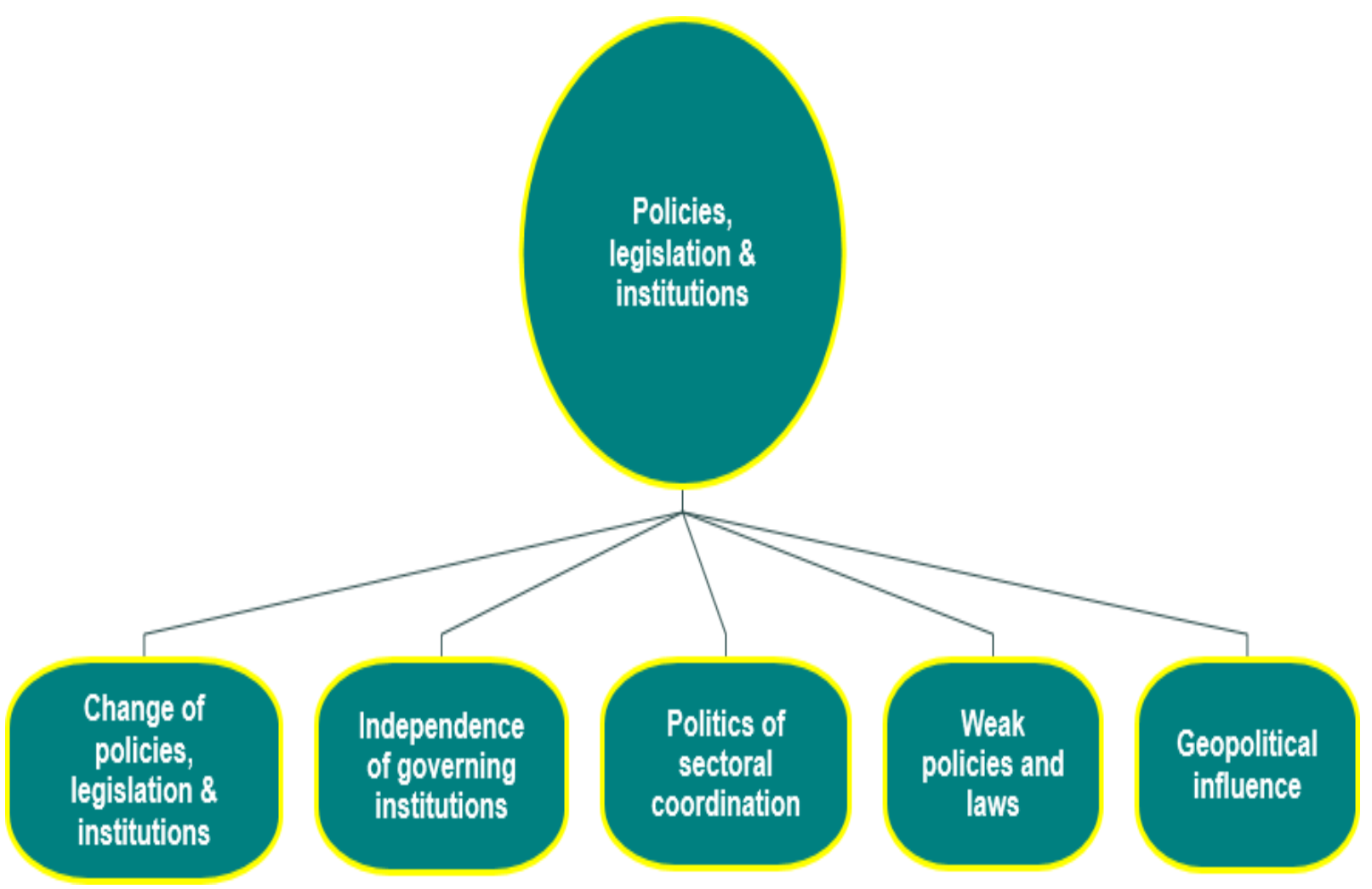


8D. Management of Energy Security

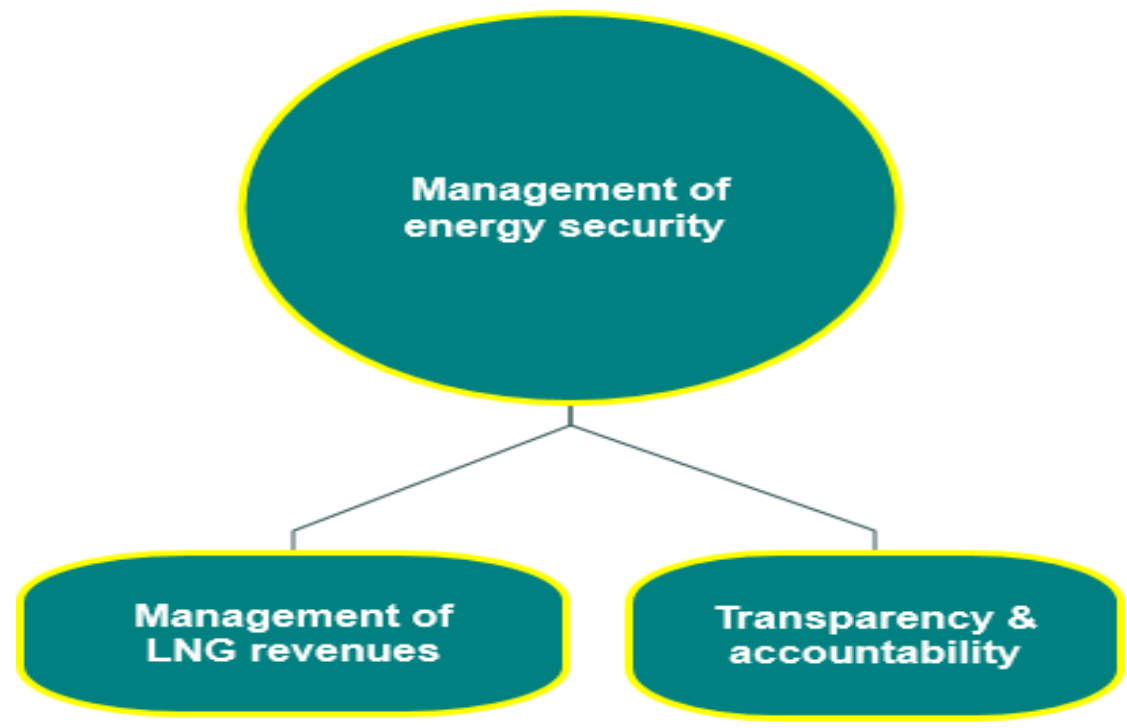


8E. Best Approaches to Energy Security

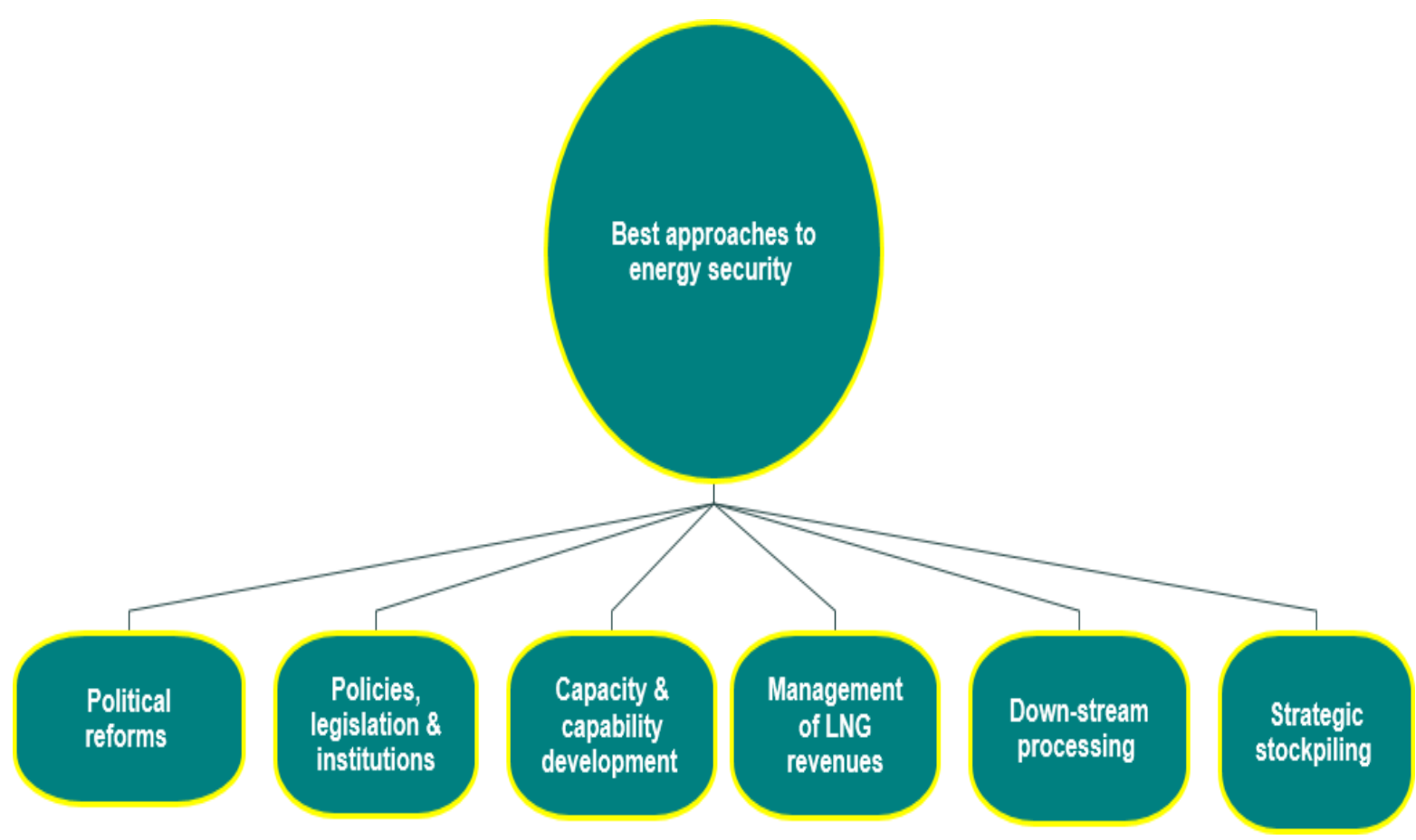




\section{Appendix 9. Accountability Reports}

\section{International Development Agency Report}

\section{A. United Nations Development Programme Human Development Report 2014}

The United Nations Development Programme Agency (UNDP) is one of the international organisations that has been playing a supporting role in the development of PNG. The PNG Human Development Report 2014 entitled 'From Wealth to Wellbeing: Translating Resource Revenues into Sustainable Development' is the second since 1998. The report was selected for analysis because of its significance to energy security in that it assesses development against the natural resource boom in PNG. The focus of the analysis was on a) purpose of the report b) audience of the report c) outcomes of the report.

\section{Purpose of the Report}

The report identifies these purposes: (1) to review the extent to which Papua New Guinea's revenues from extractive industries have led to practical human development outcomes; (2) to reveal lessons from other countries that can be useful for Papua New Guinea; (3) to give emphasis to some specific innovations from Papua New Guinea's experience that can contribute to development in other countries; and (4) to stimulate, inform and shift the debate in the country to enable leaders to make appropriate choices for the wellbeing of citizens.

\section{Audience}

The report was commissioned by the O'Neill government in 2013 after a Pacific Symposium on Extractive Industries and Human Development held in Fiji assisted by the UNDP and National Human Development Report Steering Working Committee (NHDRSC). The report was prepared for the Government of PNG and other interested governments.

\section{Significance}

The report reviews the state of human development in PNG and specifically examines the ways in which the extractive industries have contributed positively and negatively in this respect. PNG had experienced a stable unprecedented economic growth in the region on the back of the extractive industries and the report predicted the LNG to quadruple the 
economy by 2021. But the report shows that there has been little progress in development despite this growth and abundance of natural resources due to governance issues and challenges. This section discusses some of the implications of these for energy governance and energy security.

Firstly, the report showed that despite 14 consecutive years of economic growth arising mainly from the extractive industries, there has been little change in poverty levels in the country. It noted that while there have been some measurable achievements in terms of improvements in human development (increases in life expectancy, per capita income and educational achievement), many of the indicators are less positive.

Secondly, the report contended that there has been a positive contribution from the extractive industry to PNG's development in the form of significant revenue flows to the government, cutting-edge innovations to enhance revenue and transparency at the national level, as well as the involvement of some communities in some operational decisionmaking. These include positive impacts such as recent initiatives addressing service delivery, governance, and policy direction that provide useful guides for the future action.

Thirdly, the report reviewed international experiences and noted that mining and petroleum have not always been the driving force of national development. The report argued that many of the developing countries including PNG are caught in the 'paradox of plenty' where they have been plagued with a 'resource curse' and 'Dutch Disease'. Further the report argues that if growth-based extractive industries are not managed well by the government this could lead to a range of negative effects such as stunted economic growth, corruption, weak institutions, conflict, human rights abuses, and poor human development outcomes.

Finally, the report, based on a review of the state of human development and the experience of the extractive sector in PNG, along with case studies and lessons from the national and international experience, presented a range of policy options to assist in better translating minerals and oil revenues into a more sustainable and inclusive forms of human development.

The general implication is that the key issues and challenges debated in the report seem quite disturbing after the first LNG export to Asian markets in 2014. The economic situation in PNG worsened during the LNG windfall from 2015-2017 instead of improving 
despite some improvements based on the proposed governance framework. The report suggests that governance will continue to affect the development outcomes. This is because political interest appears to override national interest given the nature of rent-inducement. There have to be some strong actions taken by the government at political level to continue to improve and strengthen the governing institutions. These challenges need to be proactively managed.

\section{2: Government Reports}

\section{A. PNGEITI Reports 2013, 2014, 15 and 16}

The PNG Extractive Industry Transparency Initiative (PNGEITI) is an initiative established by the Government of PNG in 2013 to promote good governance in the extractive industry. It is a Multi-Stakeholder Group (PNGEIMSG) comprising of government agencies, CSOs and mining and petroleum companies in PNG. These reports are a culmination of a collaborative effort by the PNGEIMSG to report on the 2013, 2014, 15 and 16 financial years and how the sector impacts on the economy and management of revenues it generated from the mining and petroleum. Four PNGEITI reports $(2013,2014,15$ and 16) are analysed for their implications on energy security.

\section{PNGEITI 2013 Report}

The PNGEITI report of 2013 was compiled and published in 2016.

\section{Purpose}

The purpose of the report is to provide a picture of the extractive industry's contribution to the economy and management of revenues generated from the 2013 financial year in order to inform political governance of energy (liquid fuels) in terms of transparency and accountability as a first-time candidate of the Global Extractive Industry Transparency Initiative. The outcomes of the reports are analysed and compared separately to see the progress of governance. 


\section{Audience}

The report was commissioned by the PNGEIMSG and written by the Ernest and Young Consultant (EY). The report is intended for the GoPNG, extractive industry companies, CSOs, international development partners and Global Extractive Industry Transparency Initiative.

\section{Significance}

The report is important to the governance of extractive industries in PNG and, therefore, the energy sector. The report found that the sector has both positive and negative social, economic and environmental impacts and affirmed findings explored in detail in the UNDP publication, Papua New Guinea National Human Development Report 2014. It offers significant insights into why the wealth generated by the sector has not been translated into a better standard of living for the majority of Papua New Guineans. These include lack of transparency, under resourcing and weak capacity of government organisations.

Second, the report also found that DPE has not been consistent in performing detailed reviews or audits of the data due to resourcing constraints. However, the report found that the data reported by Oil Search is materially consistent with the one from DPE as the only company producing annual reports.

Third, the report found varied levels of capacity and transparency and noted that IPBC has been described as having a systemic lack of transparency. Given this governance issue in SoEs, the report is quite sceptical on whether the recent reforms relating to the realignment of government businesses via $\mathrm{KCH}$ will perform better than its predecessors.

Fourth, the report found that the management and distribution of revenues are considerably less transparent because the corporate income tax and dividends from the extractive sectors are recorded in the national budget as separate line items while other revenues are recorded in various places:

- Oil and gas royalties and licence fees are recorded in the Joint Department of Petroleum and Finance Trust Accounts

- Mining royalties, production levies and licence fees are recorded in the financial reports of the MRA

- Dividends from NPCP are recorded by the IPBC, as trustee of the GBT 
- Equity in oil and gas and mining (NPCP, Petromin, and MRDC) and sale of mineral commodities (Ok-Tedi Mine, Petromin) are recorded in the annual reports of the relevant entities. Development levies are recorded in Finance Trust accounts.

- Some benefits to regions impacted by the extractive industries are set out in law via royalties, equity stakes, dividends and compensation arrangements.

- Others are included in memoranda of understanding on a case-by-case basis; the new PNG LNG project, for example, includes many benefit-sharing arrangements.

The report found that these agreements are in most cases not public, and accountability mechanisms vary significantly. Firstly, the royalties and levies (oil and gas) are held in trust accounts. Second, the category, number, and balance of trust accounts in use could not be reliably identified, even by the Auditor General. Fourth, the Trust Account Spending has not been incorporated into State Budget Expenditure leaving significant risk of abuse. Moreover, the auditing of government accounts is challenging due to under-resourcing and lack of capacity both of the Auditor-Generals office itself and the entities reporting to it. Finally, the recent audit reports indicate serious gaps and inconsistencies with provincial and local-level governments.

The report noted that although the government publishes a number of budget papers, there is insufficient public information on the budget process. In addition, it noted some reforms in managing resource revenues such as SWF.

Fourth, the report found that the license allocation and registration is unsafe because it is handwritten in ledgers and it called for the system to be improved in a modern fashion. In addition, it also found that DPE's own review reveals a 50 percent rate of failure to comply with requirements including the validity of work programs being implemented and payment of license fees. The report also found that DPE does not have a website with no publicly available information on the technical and financial criteria used to award licenses or non-trivial deviations from the applicable regulatory regime in awarding licenses.

Moreover, the report found that GoPNG does not require companies to disclose the ultimate beneficiary owners of companies producing oil and gas or minerals and a publicly available register of beneficiary ownership in extractives entities.

Finally, the report found that the agreements relating to the social expenditure Mandatory Social Expenditures, which are agreed on a case-by-case basis between the government and 
project proponents are not disclosed. It noted that interested parties will in no way ensure that payments are being made in accordance with those agreements, given the confidentiality of the information. Therefore, the report encouraged disclosure of these agreements. But it noted that at least that some companies had voluntarily disclosed social expenditure ranging from zero to millions of kina.

The report drew attention to the fact that there have been huge promises made with significant frustration in realising them. The availability and reliability of data is a major challenge in PNG. In addition, the report confirmed a lack of adequate resourcing and talent to carry out their role effectively. The report emphasised that absence of availability and reliability of data could permit fraud and corruption from occurring undetected. The report, therefore, recommended the implementation of robust systems and processes. The capacity to implement them - should, therefore, be a priority for government agencies. The report also noted that not only was there a lack of cooperation by the companies but also an information delay and incomplete submissions of information. The report stated that, despite information gaps and inconsistencies, these had shed some light as a positive step towards improvement.

\section{2014 PNGEITI Report}

The PNG EITI Report 2014 was compiled and published in 2016.

\section{Purpose}

The purpose of the report is to provide a picture of the extractive industry's contribution to the economy and management of revenues generated from the 2014 financial year in order to inform political governance of energy (liquid fuels) in terms of transparency and accountability. The outcomes of the reports are analysed and compared separately to depict the progress of governance.

\section{Audience}

The report was commissioned by the PNGEIMSG and written by the Ernst and Young Consultant (EY). The report is intended for the GoPNG, extractive industry companies, CSOs, international development partners and Global Extractive Industry Transparency Initiative. 


\section{Significance}

The report found that the extractives industry contributed $12.7 \%$ of government revenue in 2014, compared with 7.5\% in 2013 as a backdrop of PNG LNG project. This increase also brought positive and negative impacts, according to the report. On one hand, it provided employment, training and revenue, and infrastructure development while on the other hand, it could also be a source of social tensions related to benefits distribution and negative environmental impacts.

Second, the report found that the legal framework and fiscal regime is relatively robust but the implementation aspect of it is challenging due to capacity and a lack of accountability, particularly at local levels. Further, the lack of transparency also permits corruption. The report revealed that the details of contracts and licences related to mining and petroleum are confidential and not publicly available. The government does not only require companies to disclose the ultimate beneficiary owners of companies producing oil and gas or minerals but also there is no publicly available register of the beneficiary owners of the corporate entities in the sector.

Third, the report found that there have been some improvements in the management and distribution of revenues based on strategic and rule-based fiscal police process with the SWF. However, it was also noted that it is difficult to obtain information relating to subnational transfers and payments linked to extractives revenue. It also made clear that transparency mechanisms vary and the capacity of sub-national governments is limited. Auditing of national and sub-national governments is constrained by the capacity issues at the Auditor General's Department and other entities which it is auditing. The report raised a concern that none of the state-owned entities had audited their 2014 accounts.

Fourth, the report found that many extractive companies contributed to the communities. The have made provisions that are far beyond the direct economic benefits and employment in different ways (both voluntary and mandated), yet also their reports appear to be varied from social expenditure to commercial expenditure. The companies' expenditures were noted in their support for health, education and community projects, among others. Infrastructure Tax Credits were claimed by the companies on the investments in approved infrastructures. 
Fifth, the report found that oil and gas projects have had significant positive and negative impacts on affected communities. It pinpointed a concern that DPE's production figure appears to be consistent with those provided by Oil Search but not with those of ExxonMobil and Petromin. The report noted that the same problem of lack of capacity identified in 2013 report still exists.

Moreover, the report acknowledged that MRDC has provided the data relating to value of the assets they hold for the people of PNG due to the stakeholder pressure upon 2013 report. There is, therefore, a sense of progress towards a greater transparency.

Finally, the report found that nearly all reporting entities submitted data in terms of reconciliation of revenue streams. However, in some cases, some of the reports were submitted as incomplete drafts. This has resulted in insufficient time to properly investigate variances and gaps. There was also lack of capacity to investigate where variances were found. The problem of defining revenue streams and the reporting of accrued amounts instead of cash payments also caused some of the unexplained variances. Interestingly, many key revenue streams had doubled in 2014 compared with 2013 because of the PNG LNG project.

Generally, the report found that most recommendations in the 2013 report were not implemented. This practice was also encountered in the 2013 report. Despite some progress in the reporting, there are still some inconsistencies in data due to late submission or the unwillingness of some companies to comply. The SoEs have not been audited with the exception of the MRDC due to pressure from the stakeholders. These issues identified by the 2014 report suggest that the governance of petroleum and oil and gas revenues yet remain a classified practice by the government and companies. Given the rampant corruption involving political corruption, rent-seeking and patron-client in the public and private spheres, it would be quite challenging to have an accurate financial report. Distortions are highly likely given the implementation of relatively few recommendations from the first report. If this continues, it will affect PNG's membership and erode its international governance ranking. 


\section{2015 PNGEITI Report}

The 2015 PNGEITI Report was compiled and published in 2017.

\section{Purpose}

The purpose of this report is to continue to stimulate discussions on the management of the sector and enhance an emerging trust between local communities, government and the industry for greater transparency and accountability. The focus of analysis in this report is specifically on Oil and Gas.

\section{Audience}

The report was commissioned by the PNGEIMSG and written by the Ernst and Young Consultant (EY). The report is intended for the GoPNG, extractive industry companies, CSOs, international development partners and Global Extractive Industry Transparency Initiative.

\section{Significance}

The report remarked upon the effect of falling LNG prices that were continuing to affect government's fiscal capacity. It also noted positive and negative impacts on the affected communities. In addition, the report noted the absence of production data by chronic underresourcing and a lack of capacity in DPE. On the positive side, the reported noted DPE's progress in developing a licensing database and implementing a registry system by scanning the relevant documents. However, the report recommended increasing resourcing at DPE to facilitate the additional changes required to adhere to the EITI Standard.

Moreover, the report noted the beneficial owners are not disclosed by the companies, it only reports on beneficial owners of material entities. This was established through direct enquiry, reference to corporate websites and annual reports. The MSG has begun work to ensure that by 2020 this information is disclosed.

The information relating to transfers and payments to subnational governments is difficult to obtain as reported. In terms of reconciliation of revenue streams, the report found that the response was encouraging but it also suggested that there should be more authorised officers signing the templates in order to give confidence in the quality of the data. The report further noted variance in all revenue streams reconciliation. The report also stated that in terms of reliability of data, of all the reporting entities, only $58 \%$ provided signed 
templates. The report noted that all companies have their audits based on international standards. Most government SoEs however do not provide audit reports and previous statements, according to the same report, had indicated shortcomings in the reliability of accounts. The report did not cover social expenditure as it is not defined in EITI standards. However, companies may claim infrastructure tax credits if they invest in approved infrastructure according to the report. Generally, the report noted that there has been some progress made against previous recommendations in the 2013 and 2014 reports and that this is expected to continue in the years to come.

The 2015 report also made some recommendations as follows:

1. Reconciliation differences and EITI reporting process.

2. Material revenue streams to include group tax and foreign contractor tax in future reports.

3. Engagement of government stakeholders to increase EITI participation.

4. Reporting of subnational payments, already under consideration through a scoping study.

5. Increase clarity and reporting of quasi-fiscal expenditure.

6. Increase the transparency of the infrastructure tax credit scheme.

7. DPE to establish criteria for the transfer of oil and gas licensees.

8. The MSG to consult with EITI to provide more clarity on definition of social expenditure.

\section{2016 PNGEITI Report}

The 2016 PNGEITI Report was compiled and published together with 2015 report in 2017.

\section{Purpose}

The purpose is to not only stimulate further discussions on the management of the sector but also provide an update on the government's efforts to act on some key recommendations made in the earlier EITI reports. The focus of analysis in this report is specifically on oil and gas. 


\section{Audience}

The report was commissioned by the PNGEIMSG and written by the Ernst and Young Consultant (EY). The report is intended for the GoPNG, extractive industry companies, CSOs, international development partners and Global Extractive Industry Transparency Initiative.

\section{Significance}

Firstly, this report is significant because it forms the basis of review and assessment for PNG's upcoming validation in 2018. The report stressed the impact of falling commodities that affected the communities. It also noted that the projects brought significant impact to the community, both positive and negative. The report noted that the SWF was established but it has yet to come into operation. It also emphasised the fact that the revenue in 2016 was affected due to falling commodity prices and natural disasters. The report also yet again underscored the problem of non-disclosure of beneficiaries of the companies other than information on beneficiaries of material entities through direct enquiry, reference to corporate websites and annual reports. The report recommended this to be reported by 2020.

Furthermore, the report drew attention to the fact that information relating to transfers and payments to subnational (provincial and local level) governments in PNG is difficult to obtain. It was also noted that reconciliation of revenue streams was encouraging but it also suggested that there should be more authorised officer signing the templates in order to give confidence to the quality of the data. The report brought to light the variance in all revenue streams' reconciliation. The report also stated that reliability of data is only $58 \%$ based on reporting companies' signatures. There was no clarity on social expenditure but companies may claim infrastructure claim if they invest in approved infrastructure.

Generally, according to the report, there have been some improvements in terms of implementation of recommendations in the previous reports and that progress will continue.

In summary, the reports (2015 and 2016) underlined the many similar issues, challenges and recommendations of transparency and accountability of resource revenue management in relation to taxation compliance, financial reporting and lack of capacity. 


\section{B. Final Tax Review Report (Issue Paper Nos. 1 and 2)}

This section summarises the main findings and recommendations of the report (from Issue Paper Nos. 1 and 2) and its significance. The focus in this analysis is on petroleum taxation. The Tax Review Report was prepared by the Taxation Review Committee commissioned by GoPNG.

\section{Purpose}

The main purpose of the review is to improve the current PNG's taxation regime into a more competitive, fair, simplified, and transparent tax system so as to build confidence in taxpayers. Moreover, it seeks to realign the tax system in such a way as to strategically leverage and maximise windfall gains from non-renewable extractive sectors to support, stimulate and grow such sectors as agriculture, fisheries, tourism, forestry, manufacturing, and Small to Medium Enterprises (SMEs).

The review covers the following areas:

1. Personal Income Tax (PIT);

2. Corporate Income Tax (CIT);

3. Excise and Customs Tariff;

4. Operation and efficiency of the Goods \& Services Tax (GST);

5. Mining and Petroleum Taxation Regime;

6. Land, Property and Capital Gains Tax;

7. Non-Tax Revenues (including charges and levies);

8. Small Business Taxation (SMEs);

9. Advantages and Disadvantages of Tax Incentives; and

10. Tax Administration (including taxpayer compliance and the efficiency, simplicity, collection effort and protocols of PNG's tax and revenue administration).

However, this part focuses primarily on (2) Petroleum Taxation Regime and Corporate Income tax (CIT).

\section{Audience}

The report is intended for government and private sector, and others who are interested in the resource sector. 


\section{Significance}

The taxation system in PNG appears to be unfit for purpose and needs review. The last comprehensive tax review was done in 2000. The Income Tax law of 1959 is currently being used by the government to administer tax regime in PNG. It is an important piece of legislation that ensures the government generate and redistribute revenues from taxpayers in a transparent and accountable way. The same applies to the IOGCs and NOGCs in the petroleum and energy sector where Internal Revenue Commission (IRC) and PNG Customs Services (PNGCS) administer this process.

The report found that the current tax regime has evolved over many years and has outlived its purpose given the changing social, economic, technological, demographic and environmental challenges. Second, it found that there is no overarching policy framework with a clear vision to administer tax in PNG. Third, PNG's tax administration challenges (such as technical skills, funding levels, etc.) are due to lack of investment in modernising the revenue institutions. Finally, the report recommended that PNG should undertake reforms to improve returns from the natural resource extraction sector in order to reduce risk in state equity participation.

The report made the following recommendations for improvement in light of the issues and challenges from the main findings:

- Overarching policy

- Revenue Administration

- Improve tax administration

- Upgrade resource taxes to produce a fair return to Papua New Guinea for the depletion of finite natural resources.

- Reduce tax incentives and manage them transparently from a whole of the economy perspective, led by a new Economic Development Board (EDB).

- Capital gains should be taxed, but initially, only some classes of real property and natural resource assets should be taxed. Customary land and the family home should be excluded. The tax will only apply to gains accumulating after the commencement of the tax. (See the Final Tax Review 2015). 
The issues and challenges including the recommendations made in the report are significant considerations in the governance of taxation and energy security in PNG.

\section{Research Reports}

\section{A. National Research Institute Research Reports}

The National Research Institute (NRI) is an independent government policy think tank. Its main role is to research and inform government policies. The reports were based on the research on the government's policy approach and decisions in governing and managing oil and LNG revenues in PNG.

Three NRI research reports considered relevant to energy governance and energy security are analysed here:

1. Report on PNG's 2015 Sovereign Wealth Fund Bill: Key Weaknesses and Proposals for Improvement (2015)

2. Report on State's acquisition of equity in Oil Search Ltd has significant implications for the PNG economy with significant welfare implications (Yala, 2014)

3. NRI Special Report - Proceedings of the 2014 Papua New Guinea Tax Review and Research Symposium (Odhuno, 2014).

\section{PNG's 2015 Sovereign Wealth Fund Bill: Key Weaknesses and Proposals for Improvement}

\section{Purpose}

The purpose of the two reports respectively is a detailed analysis of the SWF and UBS loan. In the former, the analysis is made on how SWF would manage LNG revenues. The latter is an analysis of the UBS loan.

\section{Audience}

The SWF and UBS Loan research reports are meant for the government and researchers who are interested in understanding how oil and LNG revenues are governed and managed. This includes the implications of acquiring loans. 


\section{Significance}

Successive elected governments have recognised the need for the country to establish a SWF as a governance mechanism to better manage and translate the revenues from the extractive industry into development outputs and outcomes. Provision for such a Fund to be established requires enabling law for it to be operationalised.

The Bill on SWF was first introduced by the Somare government. This Bill proposed three funds namely: Infrastructure Fund, Stabilisation Fund and Savings Fund (Future). However, the O'Neill Government made some significant changes to the original Bill via an Organic Law of 2012 and 2015 respectively. These changes were related to their deposit and withdrawal rules, the governance arrangements, the Investment Mandate, and the role of the responsible Minister.

First, the OLSWF Bill was amended by the O'Neill Government in 2012 with two funds namely: Development Fund and Stabilisation Fund. In 2014, the O’Neill Government amended the OLSWF by replacing the Development Fund with the Savings Fund to deal with intergenerational equites.

The 2015 OLSWF provides for the establishment of the two funds, which are significant to the governance of energy. The Stabilisation Fund is not only aimed at maintaining a steady level of government revenue in the event of major fluctuations in global commodity prices but also to cushion the impact of external shocks on the internal structure of the economy given PNG's high dependence on resource revenues. This also helps in avoiding inflation and minimising the negative impacts of an exchange rate appreciation on the other export sectors, for instance, Dutch Disease or resource curse.

However, the Development Fund was replaced with the Savings Fund in the 2015 OLSWF. The government saw the country's need to invest in social and physical infrastructure that would generate higher returns than investing it in long-term financial asset.

The Savings Fund was aimed at providing a means of preserving the real (inflation adjusted) value of extracted mineral and petroleum resources through long-term investment for the benefit of current and future generations. This would allow the current income to be locked away in a long-term financial asset in order to achieve intergenerational equity based on the belief that it is better to save now than future. 
The changes made by the O'Neill government could have implications for energy governance.

There have been two major implications detected by NRI related to changes to the subfunds. In the former, the replacement of the Development Fund with the Savings Fund appears to be an irrational option made by the government given the dire situational need of the country. This Fund was the best option available for the government to consider given that the country needs investments in infrastructure development, since investments in this sector would have paid huge returns to drive other growth sectors. These growth sectors would then accumulate returns for future savings. Therefore, the balance between savings and investment would have been reached in the course of this development process by the catering for, and securing of, present and future generations. In the latter, the Savings Fund may be affected by the market dynamics such as price fluctuations and economic shocks. There is no guarantee that future savings will generate more returns. The complexity of the changing political and economic environment means that it is quite difficult to predict the scenario when dealing with long-term financial assets. The Development Fund is economically viable for an optimal output and outcome as it cushions the economic surprises.

The third implications are the deposit and withdrawal rules of the Stabilisation. NRI identified that the OLSWF 2015 is more complex than the 2012 one because it makes it more difficult for the implementation and forecasting of the balance of the fund. The period of calculating the moving average from 15 years has been reduced to 5 years (with a 2 year lag). This rule will more closely reflect the actual volatility in receipts and thereby reducing the 'smoothing' purpose of the Stabilisation Fund. As it is, the withdrawal formula does not target stabilisation in the event that there is disruption from the economic environment. This scan be destabilising because the proposed formula could lead to depletion of the Stabilisation Fund. In addition, this opaqueness of the formula of withdrawal could lead to mismanagement of the fund because there would be less public scrutiny. In light of these implications, NRI has recommended that Development Fund be brought back into law and that the withdrawal formula should be re-designed in order to align the goals of stabilisation with the preservation of the fund for continued use.

However, NRI's analysis and recommendations do not appear to have been taken seriously by the government. NRI recommended that through a subordinate legislation: 
1. The Development Fund which was part of the 2012 Legislation should be reintroduced. It was created to set aside funds for key infrastructure development. While intergenerational equity is an important consideration which is addressed through establishing the Savings Fund, the present generation in PNG suffers from poor infrastructure and its needs have to be equally met. In other words, PNG's immediate development needs are too great to lock money away for future generations only, and current and ongoing investments in social and physical infrastructure would pay higher returns than financial investments could. Indeed, the economic growth stimulus created by the Development Fund will provide opportunities and benefits for both the present and future generations.

2. The withdrawal formula should be re-designed in order to align the goals of stabilisation with the preservation of the fund for continued use. This is because transparency, in terms of flows into and out of the SWF, and the release of realtime information together with the maintenance of a vested interest of the wider population in the financial health of the Fund are critical to containing the risks of mismanaging the SWF'.

NRI's reports have isolated the shortcomings and implementation problems of the 2012 and 2015. Had these recommendations been taken into account by the government when redesigning the model, it would have placed PNG in a much better position to weather the economic and fiscal crisis in faced in 2015-2017.

Finally, and of concern for energy governance, the government has not operationalised the 2015 OLSWF. The government has not provided any reason as to why it has not administratively established a SWF. Given this situation and based on NRI's analysis and recommendations, I believe, based on observation, that it would be likely that due to governance issues relating to corruption and the establishment of $\mathrm{KCH}$ and its subsidiaries the government may have delayed this process of implementation. In addition to that, there is a possibility that the replacement of the Development Fund with the Savings Fund may permit political elites with vested interests to save generational funds outside of the intended purpose. The controversial UBS loan as reported in the media shows that the LNG revenues have been mortgaged and therefore, it may have affected the creation of the SWF. The next report of the NRI on UBS loan should share some light of my observation. 


\section{NRI report on State's acquisition of equity in Oil-Search Ltd has significant implications for the PNG economy with significant welfare implications}

\section{Purpose}

The aim of this report is to discuss the implication of the State's acquisition of the equity in the Oil-Search Ltd.

\section{Audience}

This report is meant for the government and researchers who are interested in understanding how oil and LNG revenues are governed and managed. This includes the implications of acquiring loans.

\section{Significance}

The UBS loan was described by the O'Neill Government as the best commercial financial arrangement to participate in the LNG. The O'Neill Government signed a deal with the United Bank of Switzerland (UBS) for a K3 billion loan to purchase Oil Search shares in the PNG LNG. The NRI argued that this loan was not good for the country based on the past experience. Therefore, they have outlined five implications which will be analysed.

Firstly, the UBS loan was sought outside of sound fiscal management laws and legal governance. Any loans involving huge sums of money require a Parliamentary approval. In this case, the loan, although approved by the NEC, did not follow proper legal process. The acquiring of such a loan has major implications on the national budget because the government is committing itself to repay the debt. The NEC could have been misled by the purpose of the deal. Therefore, the legitimacy of this loan is highly questionable, legally flawed.

Secondly, the acquisition of UBS loan implies that the direct State commitments are against the spirit of the SWF first established by the government. That is to say that repayments requirement of the UBS loan take precedence over payments to the SWF, thus undermining the original purpose of the SWF, to act as a protective mechanism to guard LNG wealth for future generations of PNG citizens. It is clear that the up-spending and financial commitment by the government undermines those existing key legislation and mechanisms to promote fiscal discipline and ensure prudent management of public finances, in this case the LNG revenues. The experience of looting of Mineral Resources Stabilisation Fund 
during the late 1980s, the Coffee and Cocoa Stabilisation Funds, and others suggests that this may be the case. The probability of corruption in terms of diverting the funds away from its intended purpose is highly likely. The SWF has not been fast-tracked due to this interest-constraint as it appears to be.

In addition, this loan appears to be a large amount of LNG revenue forespent which is estimated to be K4-6 billion in anticipation of the LNG-revenues. This includes IPIC and the UBS loan. What this implies is that the LNG revenues have been mortgaged against these loans and that PNG would pay dearly if it is not managed properly, given the fact that it has already by-passed the existing governance mechanisms. This large spending has influenced government's expansionary fiscal policy. In turn this has affected the revenue capacity of the budget that has led to high-level debt as the government continues to borrow and spend more, despite the burden of these loans. This behaviour is similar to what happened in the 1990s economic crisis when the government used an expansionary fiscal policy. The expected revenues from the Pogera, Kutubu, Misima, and Lihir mines were mortgaged. This triggered financial problems and eventually, economic crisis as the mines and petroleum companies generated less revenues than expected. As a result, the public finances significantly shrank and the economy was crippled, thus negatively affecting the general welfare of the population.

Moreover, there has been a lack of PNG's institutional involvement and a heavy reliance on consultant-led dealings, which has tended to undermine national institutions. The loan was drawn up by consultants with little or none supervision by the key institutions. The BPNG has been used as a rubber stamp by the government.

Finally, the NRI report recommended that the state (government) plays a minimal role in the business enterprise (SoEs). This is to ensure that SoEs perform independently and improve their underperformance. It should focus on its core business of providing public goods and services, providing overall management and regulation of the economy, and the facilitation of PNG business ownership, not state ownership. The report goes on to argue that the indirect participation of government in SoEs through state ownership is not a good option given the poor performance of SoEs. Hence, the participation of the government through Oil Search is likely to fail. This has been the case for the UBS loan when PNG government decided to sell the shares at a much lower price than at which they were 
acquired. As a result of this, PNG lost significant gains. The winners were the consultants, Oil Search, UBS and the middlemen (Yala et al, 2014).

In 2017, NRI revisited the implications made in this report and noted what has transpired over the transaction which affected the economy. It then concluded that the decision undertaken by the government was not in the best interests of PNG (NRI, 2017).

In summary, the NRI report suggests that there has been a lack of consultation by the governance institutions to assess the credibility and implications of the loan. Given this undemocratic process of loan acquisition there are many questions that have been raised, that, to some extent, have affected the economy.

\section{NRI Special Report - Proceedings of the 2014 Papua New Guinea Tax Review and Research Symposium}

This is a special report by NRI on the proceedings of the PNG Tax Review held at NRI in 2014. The focus of the report is on taxation in petroleum and its significance. Note that this report complements the Tax Review Report.

\section{Purpose}

The objectives of the report are to:

- identify concerns with the current taxation system

- describe the characteristics of a good tax system

- consider options for reforms

- and evaluate the pros and cons of those options

\section{Audience}

The report is intended for government and private sector, and others who are interested in the resource sector.

\section{Significance}

The NRI report contains discussions on the issues, challenges and suggestions for improvement in the overall governance of taxation in PNG. This report is important 
because it complements the Tax Review Report in understanding the governance of the taxation regime in petroleum and energy sector in PNG.

The following are some of the key issues and challenges discussed in the symposium. First, the report stressed that the tax arrangements for the project were settled in 2008 when the PNG LNG project participants formally signed a Resource Development Agreement that established the fiscal regime and legal framework for regulation of the project and set the terms for state equity participation in the project. Second, the report emphasised that the revenue data is deficient and does not reflect the real situation of tax in PNG. Third, the report clearly stated that Petroleum and Gas Taxation Law is covered for in the Income Tax Act 1959. The tax areas covers corporate tax, petroleum and designated gas projects which are subject to company income tax, royalties and in Additional Profit Tax (APT). According to the report, the APT now only applies to the designated gas projects.

Fourth, the report furthermore drew attention to the fact that some negotiated, projectspecific tax concessions concluded by the Minister for Petroleum and Energy could modify the operation of the general taxation legislation. In which case, they contain the terms of any state equity participation and any provisions for fiscal stabilisation. The report stated that these arrangements may conflict with existing laws which require amendments for the purpose of ensuring consistency. Finally, the report noted that the petroleum and gas agreements are strictly confidential and suggested that there is a need to make them more transparent in the interest of good governance.

\section{B. PNGINA Report 2016}

PNG Institute of National Affairs (PNGINA) is a privately funded, non-profit policy research institute, or think tank. It functions as a conduit between the private sector and the government through informed policy advice to the public service and economic and social policies. The PNGINA 2016 resource sector report (Barker, 2016) is significant for this analysis of the governance of energy and energy security.

\section{Purpose}

The report is based on INA's research and analyses on the PNG's resource sector. The report focuses on the management of resources in PNG, its implications and how these should be improved. 


\section{Audience}

The report is intended for government and private sector, and others who are interested in the resource sector. This report is part of PNGINA work funded by the private organisations and businesses organisations.

\section{Significance}

The report found that PNG is caught in the common syndrome of 'paradox of plenty'. Despite PNG being a resource rich country with mega projects such as the LNG, its economic performance is disappointing and has failed to deliver broad-based economic and social benefits. There has been a lack of maintenance and development of basic infrastructure over two decades, and inadequate investment in core skills and services, including education and training, health, law and justice, that has undermined broad-based economic opportunities, despite some valuable recent efforts. The report found that PNG has some of the worst social indicators in the Asia-Pacific region and that it is playing a catch up with its fast growing population.

The report also found that the national budget has been declining rapidly and that implementation has been restrained by a weak governance. This has affected service delivery in all sectors.

The report found that the commodity prices since mid-2014 have forced the government to review governance of resources to avoid risks associated with the resource curse and Dutch Disease that may occur as a result of over-dependence in mining and petroleum sectors. It also noted the establishment of SWF by the OLSWF but suggested that this should have been done prior to the commodity booms of 2006-8 and 2012/13. The report furthermore observed that the issues related to resource boom and bust are still apparent, but PNG has missed the recent peak in the cycle and suggested that the government should focus more on ensuring that SWF is fully established to ensure accountability and transparency of the funds. That is, it should focus on critical core and productive public expenditure, and improved revenue collection and debt management, rather than saving any revenue and currency offshore for the future gains or returns.

Moreover, the report is critical to the current governance of resources based on past experience with poor resources governance the 1990s. It emphasized that the misuse of the Mineral Resources Development Fund should be taken into consideration by the 
government to avoid similar crisis. It suggested that sound fiscal and sectoral policies, laws and regulations should be applied consistently. The report also noted that the Fiscal Responsibility Act 2006 which provides for the prudent fiscal management has been partially ignored or side-lined.

Finally, the report found that while some proposed or applied policies and legislative changes are significantly important in the resource governance, yet some have been progressed with limited or no consultation which added to the perceived risks and costs of doing business in PNG. In addition, the report raised awareness surrounding the fact that laws, including tax and labour requirements have not been consistently observed by the companies in the resource sector. For instance, it noted that often newer or privileged overseas, and some local, enterprises have been bypassing some of the processes and saving costs. This allowed them to gain a competitive advantage in the country.

The INA report's finding also resonate with the other reports analysed above in that energy governance has been a significant problem to the development in the country due to weak governance, despite some progress in policies, legislation and institutions. It strongly emphasises that the governance mechanisms have been bypassed or not consistently observed The report also warns against the risks such as resource cure and Dutch Disease which may have negative effects on the economy and future generations should these governance mechanisms and controls not be observed. 